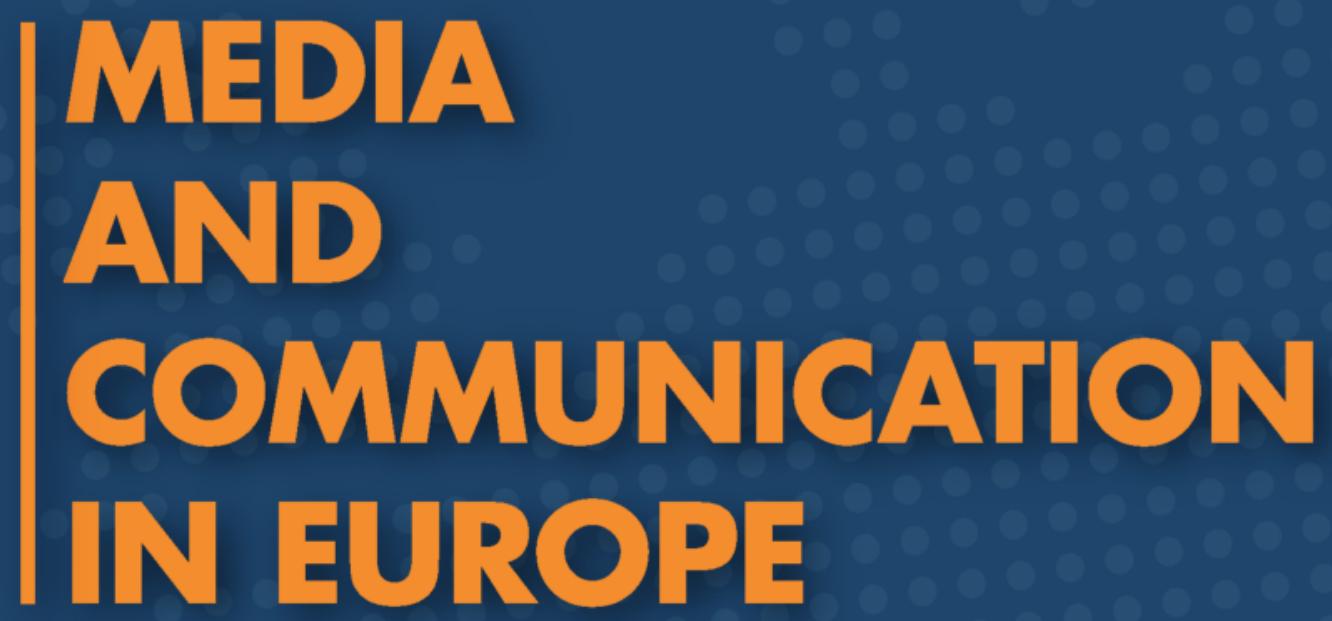

Edited by

Agnieszka Stępińska 

Media and Communication in Europe 



\section{Media and Communication in Europe}


Editor of the book:

Agnieszka Stępińska

Reviewer:

Prof. dr hab. Dorota Piontek

Typesetting:

Ryszard Skrzeczyński

Book cover:

Bartosz Stępiński

The book was sponsored by the National Science Center, Poland (grant no. NN 166 614440)

The electronic version of this book is freely available under CC BY-SA 4.0 licence, thanks to the support of libraries working with Knowledge Unlatched (KU). $\mathrm{KU}$ is a collaborative initiative designed to make high quality books Open Access for the public good. More information about the initiative and links to the Open Access version can be found at www.knowledgeunlatched.org.

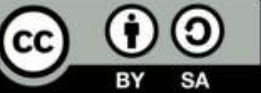

Logos Verlag Berlin GmbH

Gubener Str. 47, D-10243 Berlin, Germany, phone: +49 3042851090

www.logos-verlag.de

(C) Copyright by Logos Verlag Berlin GmbH 2014

All rights reserved

ISBN 978-3-8325-3680-0

Bibliographic information published by the Deutsche Nationalbibliothek

The Deutsche Nationalbibliothek lists this publication in the Deutsche Nationalbibliografie; detailed bibliographic data are available in the Internet at http:/ / dnb.d-nb.de. 


\section{Table of Contents}

Preface . . . . . . . . . . . . . . . . . . . . . . . . 7

\section{Part I \\ European Public Sphere}

Anke Offerhaus, Anne Mollen, Andreas Hepp: Nationalizing Europe

Regionally - The Europeanization of Public Spheres in Regional

Newspaper Reporting and the "Crisis" in Europe . . . . . . . 13

Knut De Swert, Julie De Smedt: Hosting Europe, Covering Europe?

Domestication in the EU-Coverage on Belgian Television News (2003-2012)

Veronika Pitrová: Towards Cosmopolitan Europeans: Covering Europe for the Young Audience on Public Service Broadcasting in the

Netherlands and United Kingdom

Javier Ruiz Soler: The Role of the Euroblogosphere in a Context

of the European Public Sphere

\section{Part II}

Media and Political Communication in Europe

Beata Ociepka: International Broadcasting: A Tool of European Public

Diplomacy? . . . . . . . . . . . . . . . . . . . . . 77

Sandrine Roginsky: Social Networking Sites: An Innovative Communication on Europe? Analysis in the European Parliament, the European Commission, and the European Council . . . . . 91

Gabriella Szabo: GOVCOM 2.0: The Role of Web 2.0 in Communicating EU Presidency

Arjen van Dalen: The Changing EU Presidency and the Media Agenda at Home: Coverage of the Danish 2002 and 2012 Presidency Compared 
Part III

\section{Media on the Polish EU Council Presidency}

Romy Wöhlert: Struggling for Visibility in Times of a Family Crisis. The Perception and News Coverage of the Polish EU Presidency 2011 in Germany and Austria . . . . . . . . . . . . . . . 147

Stijn Joye, Khaël Velders, Daniël Biltereyst, Thibault Bonte, Eveline Delcart: Poland Between PR and Presidency: A Quantitative and Qualitative Content Analysis of Belgian Newspaper Reporting on the Polish Presidency of the EU Council . . . . . . . . . 167

Katerina Serafeim: “This is Poland Calling!": Representations of the Polish EU Presidency in the Greek Media . . . . . . . 179

Valentina Marinescu, Mădălina Bălăşescu: The Romanian Press and European Issues: A Content Profile . . . . . . . . . . 195

Agnieszka Stępińska, Bartłomiej Secler: Polish Printed Media Coverage and Evaluation of the Polish Presidency in the EU Council Presidency . . . . . . . . . . . . . . . . . . . 211

Artur Lipiński: Presidency as a Political Battleground. Media and the Polish Presidency of the European Union Council . . . . 227

Contributors . . . . . . . . . . . . . . . . . . . . . . 245 


\section{Preface}

The book "Media and Communication in Europe" aims to promote research on media content and its role within the European context. In order to do this, the book brings together a range of international scholars, drawn from representative disciplines in the media studies and journalism. The main objective is to recognize how European issues and events are covered by media both traditional and online. Equal attention is paid to other participants of the communication process, namely political actors and citizens.

Papers in this volume are structured in three parts. Part I focuses on the role of media in a process of Europeanization of public sphere. Part II presents relations between the media and politics within European context, and Part III provides findings of the international research project on "Media Coverage of the Polish EU Council Presidency".

Part I, "European Public Sphere" brings results of five empirical studies. In the first paper Anke Offerhaus, Anne Mollen, and Andreas Hepp analyse (in a longitudinal perspective) how "Europe" and the "EU" are constructed in a process of reporting within regional newspapers in 6 countries (Austria, Denmark, France, Germany, Great Britain, and Poland) along the main developments and breaking points in the EU history. They aim in tracing a trend of Europeanization in regional papers, as well as recognizing other, possibly antidromic trends like trans- or (re-) nationalization? In their study, the Authors consider two types of Europeanization, namely vertical and horizontal.

In a second paper Knut De Swert and Julie De Smedt also presents how much attention is paid to the EU-related topics in a national media. This time, however, the object of the study is news broadcasting in Belgium, that is a country that basically hosts the European Union (EU) in its capital Brussels. While studying news media coverage, the Authors raise a question whether news about Europe and European institutions need domestication since news about them is actually domestic news about one of the relevant policy levels of the viewers (at least from an institutional perspective). In a third paper, by Veronika Pitrova, the focus is still on television, but this time the aim of study is to assess the content of the two prominent children's news programs, namely Newsround in Children $\mathrm{BBC}$ and Jeugdjournaal in the Dutch public service broadcaster (NOS). The Author evaluates whether they offer balanced coverage of current affairs in terms of geographic focus and topics and thus might serve children's socialization within the European Union. 
The first section is completed by Javier Ruiz Soler, who in a forth paper investigates bloggers who are listed in bloggingportal.eu - the biggest aggregator of the EU blogs. They are considered and interviewed as participants of so called Euroblogosphere: a virtual space where people can exchange ideas and thoughts about European issues. The central question raised by the Author concerns the contribution of the Euroblogosphere into the European Public Sphere.

Part II, "Media and political communication in Europe" includes papers that focus on the roles of traditional media as well as websites, Facebook and Twitter profiles, and blogs in processes of political communication in the EU context. The section opens with a paper by Beata Ociepka who analyzes international broadcasting as one of the elements of new public diplomacy in Europe. As three examples under a study (British BBC World Service, German Deutsche Welle, and Polish Belsat TV) show, TV stations broadcasting internationally are involved in a country branding as they shape the image of the countries in direct way, presenting the culture and promoting languages.

In a following paper Sandrine Roginsky gives an overview of the place of social networking-sites (SNS) within the European institutions (the European Parliament, the European Commission and the European Council) and investigates the types of communication activities actually undertaken by spokespersons, other mandated staff, editorial staff, commissioners, members of the European Parliament, or assistants in their practice.

Next, Gabriella Szabo examines what role web 2.0 plays in a government communication, using the Hungarian government's communication strategy employed during the Presidency of the Council of the European Union in 2011 as a case study. The findings are then discussed in a theoretical framework of public relations culture. In a following paper, by Arjen van Dalen the focus is still on the EU Presidency. The paper dicusses the consequences of the changing role of the rotating The EU Council Presidency from a communication perspective. Comparing and contrasting two Danish Presidencies (in 2002 and 2012) the Author describes how media debate in the presiding country has changed in terms of visibility and prominence of the topic.

During the six-month period of the presidency the country may attempt to attract the foreign media attention as a host of numerous meetings and events. The same time may be spent on achieving political goals and building the image of the Member State, as well as an attractive for tourists and entrepreneurs country. Thus, effectively conducted Presidency of the EU Council may improve an image of the country holding this position and this is particularly true for countries that hold the chairmanship of the EU Council for the first time. In many cases, however, the internal political events such as elections, political tensions, or controversies over domestic issues seemed to take the whole air around the country.

Part III is exclusively devoted to the international project "Media Coverage of the Polish EU Presidency" launched in 2010.1 The project provided an opportunity

1 The study was sponsored by the Polish National Science Center (grant no. N N116 614440). 
to check how much attention in the news media outside Poland was devoted to Poland and how many of them were inspired by the topic of the first Polish Presidency that started on July 1st, 2011 and ended on December 31, 2011. The aim was to recognize the actual Presidency's power of attracting media attention. In particular, the study investigated: frequency of covering Poland in the foreign media during the period of the first EU Presidency, dominant frames and perspectives used in the materials, the sources of information presented in the media (journalist, foreign correspondent, news agencies, other media), particular topics (the EU-related and non-EU related), major actors, as well as opinions expressed in the comments and analyses and the sources of these comments and analyses.

Besides investigating items related to the Presidency, all the items about Poland published in the period of six months of hosting this position were examined. This allowed to recognize the picture of the country that was drawn by the foreign media in comparison to the image of the Presidency in the Polish media. Journalistic materials (news items, comments, reports, editorials, etc.) published in three 6 week-periods: June $15^{\text {th }}-J u l y 30^{\text {th }}$, September $1^{\text {st }}$ October $15^{\text {th }}$, December $1^{\text {st }}$-January $15^{\text {th }}$ were selected for the study.

The study included 10 countries: Austria, Belgium, Greece, Germany, Estonia, Poland, Portugal, Romania, Spain, and Sweden. In this volume representatives of 6 countries present findings of their research. The papers are presented in the order on the names of the foreign countries: Austria and Germany (together), Belgium, Greece, and Romania. The volume concludes with two chapters analysing Polish data.

Romy Wöhlert compares media coverage of the topic in Austria and Germany. While studying a content of printed media in these two countries, the Author considers two factors that may have affected the coverage, namely, the bi-national relations of both countries with Poland and the self-perception of both countries with regard to its own membership in the EU as a collective entity. The findings clearly show that the economic crisis in Europe challenged the Polish EU Presidency in terms of attracting attention and developing an image of the country itself.

In a following paper Stijn Joye, Khaël Velders, Daniël Biltereyst, Thibault Bonte, and Eveline Delcart present findings of the study on the Flemish news media revealing that the representation of Poland's presidency was largely 'depoliticized'. In fact, Poland did not succeed in Belgium in positioning itself as a major political actor within the European context. At the same time, Poland was very successful in promoting and improving its cultural and touristic image.

Next paper, by Katerina Serafeim explores the news coverage of the first EU Council's Polish Presidency in the Greek media. The comparative research of printed and online news media brought to the surface the low visibility of Poland in news coverage in Greece, which was accompanied by a generally neutral attitude that enhanced the low recognition of Poland among Greeks. Nevertheless, the Greek media portrayed Poland mostly as a "new EU member" and "a new member 
of the European family", instead of "a post-communist country", which might me perceived as an image enhancement.

In a following paper Valentina Marinescu and Mădălina Bălăşescu discuss how the existing organizational and professional variables in the field of professional journalists can explain the covering level of the EU processes and events in the Romanian online and print media. The study on the Polish EU Council Presidency serves here as a case study. The findings show that covering the Polish EU Presidency in Romanian newspapers and online media was achieved mainly by providing routine events and, simultaneously, a frequent reference to the quality of the country's full membership in the European Union.

Finally, two papers written by Polish scholars reflect influence of political angle of the media organization on the Polish media coverage of the Polish EU Presidency. While Agnieszka Stępińska and Barłłomiej Secler analyse findings from quantitative part of the study, Artur Lipiński shares conclusions of his qualitative study on a content of weekly magazines. Both types of analysis clearly showed that depending on their political bias, newspapers and weekly magazines varied not only on the evaluation of Poland's performance, but also on discursive positions they used.

The volume reflects both the contemporary conceptualizations and research on various aspects of Europeanization of public sphere, including: media coverage of the European events, European blogosphere, European media organizations, as well as Europanization of national politics and mediatization of the Europan politics. Although written from different perspectives, all chapters provide clear evidence that Europeanization is not just an idea, it is actually a real process we have been experiencing. 
Part I

European Public Sphere 

Anke Offerhaus, Anne Mollen, Andreas Hepp

ZeMKI, University of Bremen, Germany

\section{Nationalizing Europe Regionally - The Europeanization of Public Spheres in Regional Newspaper Reporting and the "Crisis" in Europe}

\section{Europe and the regional press}

The EU's history is a story of continuities and breaking points in the light of political integration in Europe. Corresponding with the institutional progress, ever since the EU's founding days theorists of democracy have seen the parallel development of a European public sphere as essential for its democratic legitimacy. In this tradition a considerable amount of research has been undertaken, analysing the emergence of a public sphere within the coverage of the EU and other European institutions in mostly quality print media (e.g. Trenz, 2004; van Noije, 2010; Veltri, 2012). Research on tabloids and even more so on local or regional newspapers is rare. When undertaken at all, it typically investigates cross-border news coverage in European border regions, considering these regions as motors for European integration (e.g. Roose, 2008; Schäfer et al., 2012). The one-sided focus on the quality press in research (cf. also a conclusion of several book reviews, Nitoiu, 2013:35f.) is in so far surprising as the citizens' view of Europe seems to be strongly affected by regional newspapers that have comparably high circulations.

Within such an overall frame, we have undertaken newsroom studies in previous phases of our research. They have demonstrated that regional papers do not simply follow the same orientations as the quality press in their media coverage. Due to their specific newsroom routines, resources and restrictions, such newspapers establish their own, mostly pragmatic choices when reporting about Europe. The regional papers' orientation towards the everyday lives of their readers, as well as the journalists' need to make decisions reflecting daily production pressures, results in differences of this kind of newspaper from other types. From a journalistic point of view, their aim is often to adapt news stories that relate to their readers, which they can present in an understandable, informative and interesting way. For that reason, most regional papers belong to a type of paper that can be labelled as "reporter". Due to their reader-orientation, main events like the Euro introduction or the EU enlargement that had a significant direct, or maybe only perceived, influence on people's lives, might therefore also be treated differently in regional reporting compared to other types of newspapers (Hepp et al., 2012:168-172). 
While arguments like these are based on newsroom studies, within this article we want to focus on questions of media content. In a longitudinal perspective we analyse how "Europe" and the "EU" are constructed in the process of reporting within regional newspapers along the main developments and breaking points in EU history: Is there a considerable trend of Europeanization in regional papers similar to that in the quality press? Can we trace other - for example related to the emerging financial crisis since 2007 - possibly antidromic trends like trans- or (re-) nationalization?

If we want to answer these questions it is helpful to consider two relevant aspects. Firstly, we have to consider the EU's integration process: from the single market to a political union with the treaty of Maastricht, to a common currency until the current crisis situation. Secondly, we have to reflect very different histories and perspectives towards the EU, reaching from founding members of the EU like France and Germany, to new members like Poland, from countries with a positive attitude to the EU like the abovementioned, to those that have an ambivalent or rather sceptical view like Denmark or Great Britain. Within our following analysis we want to do both: while focusing on an aspect of Europeanized public spheres that has so far received little attention, we want to identify how regional newspapers report on transnational issues from a longitudinal perspective and in different European countries.

In order to pursue a content analysis on this matter, in the following section we explicate the concept of Europeanization and discuss the facilities and the restrictions of regional journalists reporting on European matters. Subsequently, we introduce our data and methodology. Based on our dimensions of enquiry, we then present and finally discuss our findings on the Europeanization of public spheres in regional newspapers.

\section{The multi-segmented European public sphere and political discourse cultures}

Since the middle of the 1990s a growing degree of attention has been directed towards European integration, provoking an ongoing discussion among scholars from different social science disciplines regarding the appearance and emergence of a European public sphere. Especially the role of national and transnational media was considered as providing thrust for this (Eriksen \& Fossum, 2000; Habermas, 1998, 2000; Schlesinger, 1999; Schlesinger \& Kevin, 2000). Hence, the existence of a mediated European public sphere is seen as a central feature of a democratic EU, shaping the coherence of political systems and decision-making processes. Such a transnational sphere might create various avenues through which citizens could make their voices heard by the Union's decision makers. This aspiration has been also based on the assumption that equal and open access to public debate fostered by a European public sphere could enhance the EU's transnational democracy and 
further its collective identity-formation processes. Thus, contestation through public debate within the European public sphere could compel the political authority to explain and justify its actions and policies towards the European citizens.

During the past 20 years of research, it became apparent that a European public sphere cannot be grasped merely as an extended national public sphere (Gripsrud, 2007:483-485). The European public sphere is a more complex phenomenon that can be described alongside a shared pan-European transnationalization of historically mainly national political public spheres. Within media and communication studies, it is a well-accepted starting point to distinguish a "horizontal" from a "vertical" dimension of Europeanization (Koopmans \& Erbe, 2004; Wessler et al., 2008:10, 56; Koopmans \& Statham, 2010:41). Vertical Europeanization means an increasing 'monitoring' of Europe and the EU in the public sphere of each country. Horizontal Europeanization signifies an increasing 'monitoring of' and 'discussing with' other European countries. For both these aspects of Europeanization, we can identify two further aspects which offer us four distinct criteria for the Europeanization of national public spheres on the level of media coverage (Peters, 2008:200): First, the vertical dimension of monitoring EU governance; second, the vertical dimension of a collective identification with Europe; third, the horizontal dimension of discursive exchange, meaning a shared pan-European discourse between the national public spheres; and fourth, a European discursive convergence in the national public spheres.

A preceding quantitative content analysis within our own research, for example, demonstrated a "segmentation" of the European public sphere for quality and tabloid papers in six European countries over the past 25 years: While vertical Europeanization - the increase of reporting about EU institutions and politics - can be observed over time, the horizontal dimension of Europeanization, that is the observation of other EU member states, is stagnating on a relatively high level. Collective identification with a European community emerges only faintly. Furthermore, we can argue that a European public sphere remains "multi-segmented": on the one hand regarding nations, and on other regarding transnational newspaper types. While the first is evident, because the European public sphere is articulated through different levels of the transnationalization of national public spheres, the second segmentation is more astonishing. Across the researched EU member states, we find certain types of media outlets that share - in spite of their different national background - patterns of constructing the European public sphere. Therefore, the European public sphere is multi-segmented in a dual sense: by the nations whose public spheres become transnationalized, and by the types of media outlets that report about the EU and its member states (Hepp et al., 2012:63-84; Wessler et al., 2008:40-54).

Addressing the question of how we can explain such a multi-segmented character of the European public sphere and how certain types of media can unfold such a segmenting force, the concept of "political discourse cultures" is helpful. In short, we understand political discourse cultures as specific thickenings of cultural pat- 
terns of producing, representing and appropriating political communication as well as related cultural patterns of regulation and identification. They form the socio-cultural foundation of the public sphere. While political discourse cultures therefore constitute multi-level phenomena related to the process of mediated political meaning production in total (as shown e.g. through media content), political discourse cultures also become relevant in their re-articulation in the practices of journalists.

Our investigation of journalistic practices - undertaken by conducting qualitative interviews and newsroom observations (cf. Hepp et al., 2012:85-178; Hepp et al., forthcoming) - revealed various patterns of political discourse cultures. National segmentations can be explained by 'national political discourse cultures' that are articulated by the 'nationalising practices' of journalists. At the same time we find patterns of journalistic professionalization that vary transnationally, depending on certain types of newspapers. These types of newspapers, distinguishable by their ways of addressing imagined audiences in the journalists' practices, move beyond the simplifying distinction of quality, regional and tabloid papers. Different 'types of newspapers' across our countries of investigation are therefore themselves marked by different 'political discourse cultures'.

Furthermore, we could distinguish between four types: the analyst, the ambassador ${ }^{1}$, the caterer and the reporter. Results from our research on newsroom production processes demonstrated that journalists from regional newspapers can be characterized by the term "the reporter". They focus on reporting about major events within EU politics. They feel a need to cover these stories, as major EU decisions are likely to influence their reader's everyday lives. Therefore, their readers expect them to 'report' these issues. In that on the one hand they are different from quality papers, which often apply an analytical approach to fully and thoroughly cover and analyse European issues as well as contextualize and critically assess them ("the analyst"). Tabloids, on the other hand, often cater to the imagined and pre-defined opinions of their readership ("the caterer"), for example feeding with their reporting into sensitive issues. However, this distinction cannot be drawn so clearly within all researched countries and for all newspaper titles. Across quality, tabloid and regional papers we also find newspapers of the type of an "ambassador". These outlets follow an explanatory and clarifying, almost pedagogical approach in their reporting on EU politics.

As background to our content analysis it is helpful to have this newsroom research in mind. Reflecting these findings and distinctions, it seems likely to find further differences in the re-articulation of political discourse cultures at the level of content if we compare regional newspapers with quality and tabloid papers.

1 The term "ambassador" was introduced by Heikkilä \& Kunelius (2006). However, they theorize them in a different way than we do. 


\section{Data and methodology}

The content analysis we want to present in the following sections is undertaken within the project "The Transnationalization of Public Spheres in the EU: Citizens' (re)actions", which is part of the Collaborative Research Center 597 "Transformations of the State". Our current focus on regional newspapers is the final step in a research succession that has investigated the transnationalization of political coverage in the Austrian, British, Danish, French, German and Polish print media from 1982 until 2008 against the backdrop of an emerging European public sphere. This research started by analysing political discursive articles within quality print media in the five researched countries Austria, Denmark, France, Germany and Great Britain. In a next step, the research focus was widened to also include tabloids and Poland (Hepp et al., 2012). Our final step now is to complement this content analysis with the political reporting in regional newspapers, which is the subject of this article. ${ }^{2}$

For each researched country, the regional paper with the largest circulation was chosen, which, however in order to avoid a strong focus on national parliamentary politics was not to be located within the capitals of the respective countries. The diverse sample of countries in this project reflects very different histories and perspectives towards the EU. France and Germany both represent major political actors in the EU, being among the largest countries population-wise, and also being among the founding nations. Austria and Denmark are rather small and more recent member states. Denmark and also Great Britain are typically in tendency euro-sceptic and are also not part of the Eurozone. Poland was included as one of the most recent and larger Eastern new member states with a distinct history compared to the other researched countries (due to its historical connection within the 'Eastern Bloc' and to the USSR).

Our longitudinal approach has a span of over 25 years of political reporting within Europe and stretches over very diverse phases of the European integration process, along the main developments and breaking points in EU history. Therefore, we also take into account the EU's long-term development, including main events like the establishment of the single market in the 1980s, the move towards political union in the 1990s, the introduction of the Euro, and the enlargement in the 2000s, up to the triggering of the current financial crisis in 2008. For each year in the sample $(1982,1989,1996,2003,2008)$, two constructed weeks were created. For each day in these constructed weeks, the edition of one regional paper per country was selected.

From each of these twelve editions for every year in our sample, only the political, the regional and local news sections were of interest. Within these sections, only discursive articles were chosen for analysis in order to reflect the Europeanization of

2 In order to investigate whether news coverage has changed during the so-called 'crisis', we are currently collecting data for a further content analysis wave of the year 2013. 
political discourse as a matter of opinion building. This included articles that where labelled by a journalist's name so that a journalistic editing process within the newsroom was observable; the sample also encompassed editorials and editorial page opinion articles as well as political columns, interviews and contributions from external authors such as politicians or experts. In addition, a range of other articles were selected in which political news is analysed, interpreted, argued or justified, rather than just being 'objectively' reported. In this line of argument, pure news agency material, service articles, features, letters to the editor etc. were not selected for coding as they do not represent a discursive exchange. Following this procedure, our sample consists of 11,573 articles.

Table 1

Characteristics of the country sample

\begin{tabular}{|l|c|c|c|c|c|c||}
\hline & Germany & France & $\begin{array}{c}\text { Great Brit- } \\
\text { ain }\end{array}$ & Austria & Denmark & Poland \\
\hline $\begin{array}{l}\text { Size/power of } \\
\text { a country }\end{array}$ & Big & Big & Big & Small & Small & Big \\
\hline $\begin{array}{l}\text { Length of EU } \\
\text { membership }\end{array}$ & $\begin{array}{c}1958 \\
\text { (Founder) }\end{array}$ & $\begin{array}{c}1958 \\
\text { (Founder) }\end{array}$ & $\begin{array}{c}1973 \\
\text { (Long term } \\
\text { member) }\end{array}$ & $\begin{array}{c}1995 \\
\text { (Short term } \\
\text { member) }\end{array}$ & $\begin{array}{c}1973 \\
\text { (Long term } \\
\text { member) }\end{array}$ & $\begin{array}{c}2004 \\
\text { (New } \\
\text { member) }\end{array}$ \\
\hline $\begin{array}{l}\text { Attitude to- } \\
\text { wards the EU }\end{array}$ & Euro-phile & Euro-phile & $\begin{array}{c}\text { Euro- } \\
\text { sceptic }\end{array}$ & $\begin{array}{c}\text { Ambiva- } \\
\text { lent }\end{array}$ & $\begin{array}{c}\text { Ambiva- } \\
\text { lent }\end{array}$ & $\begin{array}{c}\text { Euro- } \\
\text { phile }\end{array}$ \\
\hline $\begin{array}{l}\text { Regional } \\
\text { Newspaper }\end{array}$ & $\begin{array}{c}\text { Westdt. } \\
\text { Allgem. } \\
\text { Zeitung }\end{array}$ & $\begin{array}{c}\text { Ouest } \\
\text { France } \\
\text { Manches- } \\
\text { ter Eve- } \\
\text { ning News }\end{array}$ & $\begin{array}{c}\text { Kleine } \\
\text { Zeitung }\end{array}$ & $\begin{array}{c}\text { Jydske } \\
\text { Vestkysten }\end{array}$ & $\begin{array}{l}\text { Dziennik } \\
\text { Zachodni }\end{array}$ \\
\hline
\end{tabular}

Following our distinction in the previous section, these articles were analysed focusing on vertical and horizontal Europeanization as well as on European identification. The vertical dimension was operationalized by monitoring a certain scope of EU politics. A process of vertical Europeanization could be stated either when EU institutions become more visible within the longitudinal analysis or when an increasing focus on European policies as a main topic occurred within these articles. The horizontal dimension was operationalized by the scope of a transnational exchange of arguments. If a considerable focus on other European countries occurred, determined either by their mentioning or through directly and indirectly quoted actors from these countries we could claim a horizontal Europeanization. A far more demanding indicator, reaching beyond the aforementioned processes of Europeanization, is the process of collective identification as European. It measures whether 'objective' communicative exchange across national borders is acknowledged by its participants 'subjectively' as a common discourse. It hence defines Europeanization in terms of the emergence of a common transnational "community of communication" (Habermas, 2001; Risse, 2010:109). Hence the mentioning of we-references 
(e.g. "We, the Brits") or the naming of collective identities (e.g. "the French people", "the Europeans") were coded. ${ }^{3}$

Table 2

Dimensions and indicators of Europeanization

\begin{tabular}{||l|l||}
\hline \multicolumn{1}{|c|}{ Dimension } & \multicolumn{1}{c|}{ Indicators } \\
\hline Vertical Europeanization & $\begin{array}{l}\text { Monitoring transnational politics: } \\
\text { - Visibility of EU institutions, } \\
\text { - Focus on EU policies. }\end{array}$ \\
\hline Horizontal Europeanization & $\begin{array}{l}\text { Transnational discourse: } \\
\text { - Focus on EU countries, } \\
\text { - Quotation from speakers from EU countries. }\end{array}$ \\
\hline European Identification & $\begin{array}{l}\text { Level of Identification: } \\
\text { - European “we"-references, } \\
\text { - References to EU countries as collectives. }\end{array}$ \\
\hline
\end{tabular}

\section{Nationalizing Europe - Europe in regional newspapers}

\section{Vertical Europeanization}

Monitoring European governance - as one dimension of the Europeanization of regional public spheres - is measured by looking at the visibility of EU institutions as well as the focus on EU policies within the regional newspapers in the sample.

Figure 1. References to political institutions $(n=5,225)$

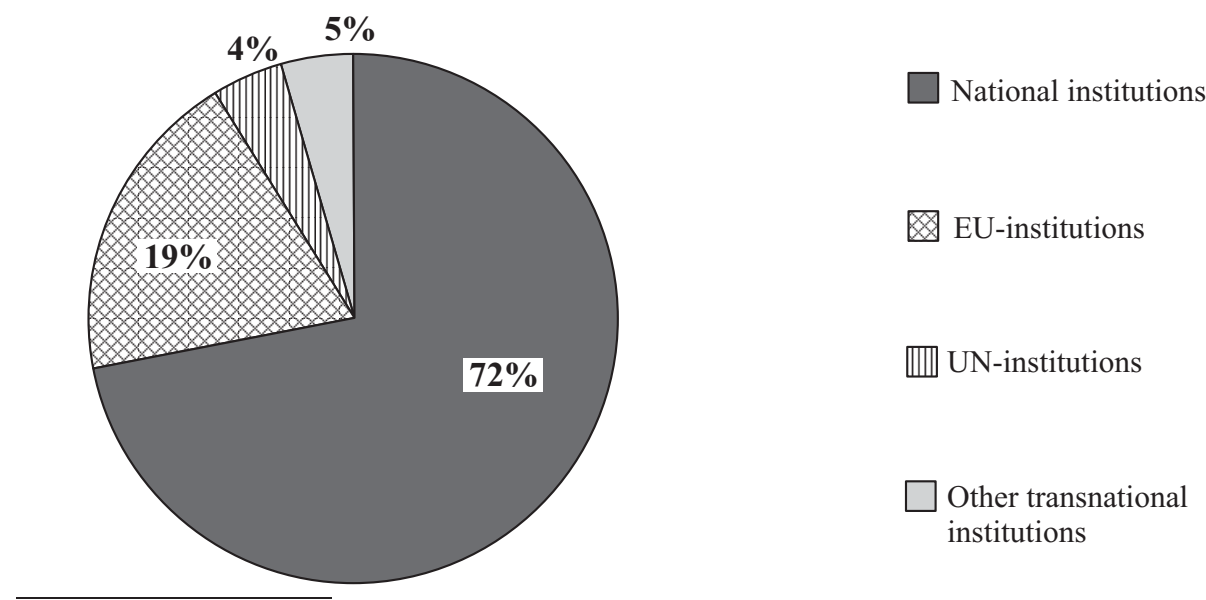

3 All relevant variables - references to political institutions, countries, speakers, topics, we-identities, and collectives identities - could be coded several times within an article. 
We see that the overall distribution of references to political institutions splits up into $72 \%$ of references to national institutions (political institutions like local, federal and national parliaments, governmental departments, courts of justice etc. were coded as national political institutions) and 19\% into EU-institutions (and its predecessor institutions), whereas UN-institutions and other inter- and transnational institutions such as alliances like the North Atlantic Treaty Organization (NATO) or the Bretton-Wood-institutions like the World Bank, International Bank for Reconstruction and Development (IBRD) and International Monetary Fund (IMF) are almost irrelevant.

Figure 2. References to political institutions over time $(n=5,225)$

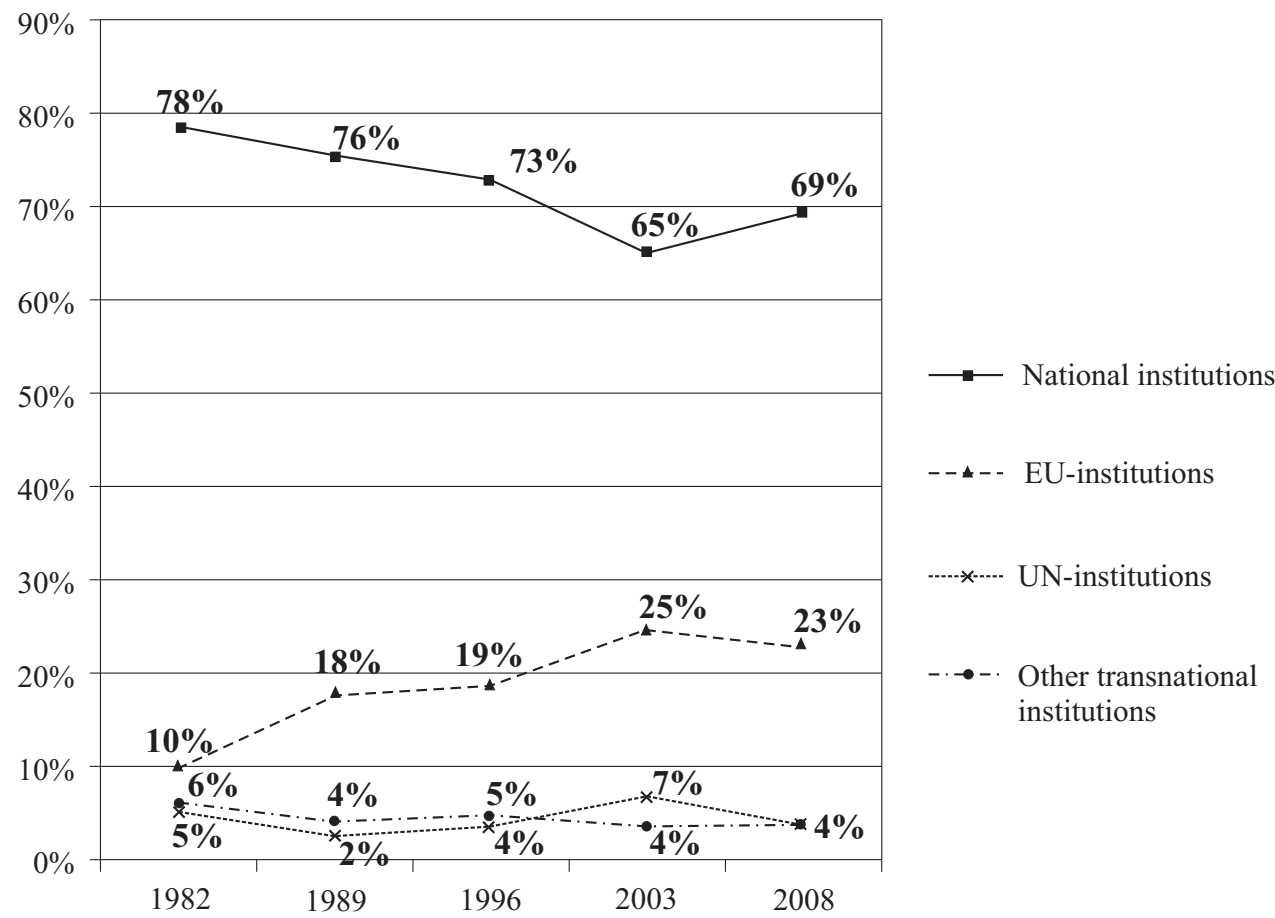

Observing the development over 26 years, we recognise a low, but more or less stable level of references to international institutions and a high, but decreasing level of references to national institutions. The process of European integration is accompanied by a continuous increase of EU references in the news coverage up to the year 2003. Since then trends seem to be returning to a re-nationalization at the expense of references to transnational institutions. But we suggest that this is not just a sign of narrowing the horizon of regional news coverage to national politics. Rather we can understand this, at least partly, as a phenomenon of readdressing national governments for the solution of European and global problems like the financial crisis. 
Table 3

References to political institutions in different regional newspapers from 1982 to 2008 (lowest and highest percentage is marked)

\begin{tabular}{|c|c|c|c|c|c|c|c|}
\hline & $\begin{array}{l}\text { Westdt. } \\
\text { Allgem. } \\
\text { Zeitung } \\
\text { (D) }\end{array}$ & $\begin{array}{c}\text { Ouest } \\
\text { France } \\
\text { (F) }\end{array}$ & $\begin{array}{c}\text { Man- } \\
\text { chester } \\
\text { Evening } \\
\text { News } \\
\text { (GB) }\end{array}$ & $\begin{array}{l}\text { Kleine } \\
\text { Zeitung } \\
\text { (Ö) }\end{array}$ & \begin{tabular}{|c|} 
Jydske \\
Vestkyst \\
en (DK)
\end{tabular} & $\begin{array}{c}\text { Dziennik } \\
\text { Zachodni } \\
(P L)\end{array}$ & Total \\
\hline $\begin{array}{l}\text { National institu- } \\
\text { tions }\end{array}$ & $\begin{array}{r}69 \% \\
(469)\end{array}$ & $\begin{array}{r}48 \% \\
(346)\end{array}$ & $\begin{array}{c}90 \% \\
(1,086)\end{array}$ & $\begin{array}{r}69 \% \\
(527)\end{array}$ & $\begin{array}{l}70 \% \\
(867)\end{array}$ & $\begin{array}{r}77 \% \\
(467)\end{array}$ & 3,762 \\
\hline EU-institutions & $\begin{array}{r}20 \% \\
(138)\end{array}$ & $\begin{array}{r}37 \% \\
(268)\end{array}$ & $\begin{array}{l}6 \% \\
(68)\end{array}$ & $\begin{array}{r}24 \% \\
(183)\end{array}$ & $\begin{array}{l}20 \% \\
(245)\end{array}$ & $\begin{array}{c}17 \% \\
(101)\end{array}$ & 1,003 \\
\hline UN-institutions & $\begin{array}{r}6 \% \\
(39)\end{array}$ & $\begin{array}{r}9 \% \\
(65)\end{array}$ & $\begin{array}{l}2 \% \\
(24)\end{array}$ & $\begin{array}{r}4 \% \\
(31)\end{array}$ & $\begin{array}{l}4 \% \\
(49)\end{array}$ & $\begin{array}{r}3 \% \\
(16)\end{array}$ & 224 \\
\hline $\begin{array}{l}\text { Other transnational } \\
\text { institutions }\end{array}$ & $\begin{array}{l}6 \% \\
39\end{array}$ & $\begin{array}{l}6 \% \\
46\end{array}$ & $\begin{array}{r}2 \% \\
25\end{array}$ & $\begin{array}{l}4 \% \\
28\end{array}$ & $\begin{array}{r}6 \% \\
74\end{array}$ & $\begin{array}{l}4 \% \\
24\end{array}$ & 236 \\
\hline Total & $\begin{array}{c}685 \\
(100 \%)\end{array}$ & $\begin{array}{c}725 \\
(100 \%)\end{array}$ & $\begin{array}{c}1,203 \\
(100 \%)\end{array}$ & $\begin{array}{c}769 \\
(100 \%)\end{array}$ & $\begin{array}{c}1,235 \\
(100 \%)\end{array}$ & $\begin{array}{c}608 \\
(100 \%)\end{array}$ & $\begin{array}{c}5,225 \\
(100 \%)\end{array}$ \\
\hline
\end{tabular}

Comparing the proportions among the countries within our longitudinal sample, we notice - as expected - for the euro-sceptical Great Britain a major concentration on national references $(90 \%)$ and the lowest percentage of EU-references $(6 \%)$. Contrasting this with France, Great Britain also rarely displays references to other international institutions. The French regional news coverage seems to be the most transnationalized one. According to our data it has the highest rates of reference to European (37\%), to United Nations (9\%) and to other transnational political institutions $(6 \%)$. The regional news coverage in Poland also has high rates of national references, which might be attributable to their shortest duration of EU membership. Although the Austrian newspaper draws more attention to national institutions, it also focuses on EU institutions.

Taking political topics as an indicator for monitoring governance on different levels, we differentiated between 'domestic policy making', 'EU policies', 'foreign and international policies' and 'other societal topics'. In this last category, we summarized topics that deal with different societal topics like economy, social problems, crime, health, science, technology, environment, media, leisure, culture etc. but that do not move the process of policy making into the foreground. Most of the topics (68\%) deal with such issues. If we focus only on articles in the sample that have the subject of policy making and compare their national or transnational orientation, we notice that domestic policies dominate with $68 \%$, EU policies are covered by $20 \%$, and foreign and international policies by $12 \%$ of the articles. 
Figure 3. Thematic focus of the article: all topics $(n=13,257)$; topics relating to policy making processes $(n=4,281)$
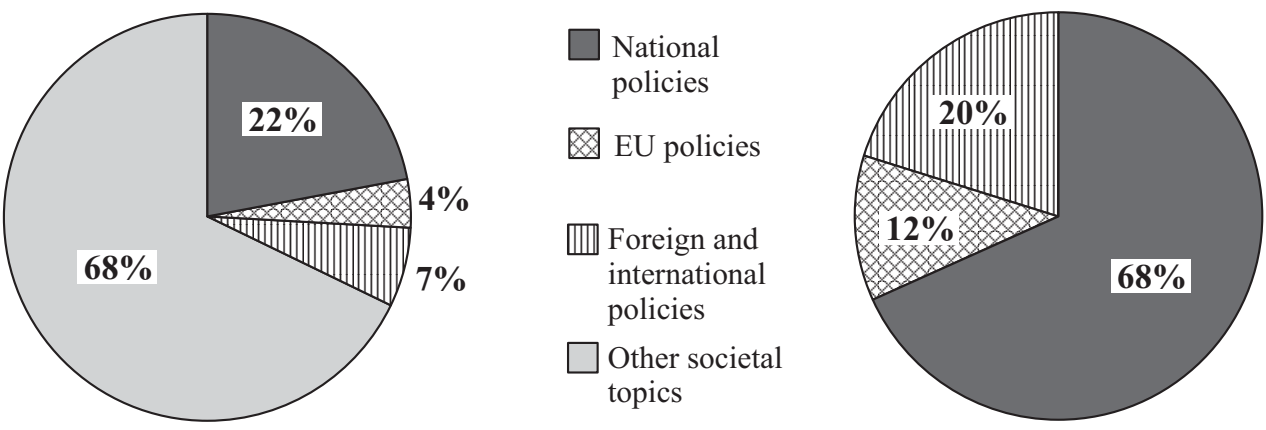

Analysing the variation over time, these proportions are comparatively stable until 2003. Again, in 2008 we can see a slight increase of domestic policies (from 66 to $72 \%$ ) at the expense of EU policies (from 23 to $21 \%$ ) as well as foreign and international policies (from 8 to $4 \%$ ).

Summarizing the results regarding a vertical Europeanization of regional public spheres, both indicators show references to the EU. Compared to the national these references are on a lower, but nevertheless visible and stable level. However, we also need to bear in mind that the Europeanization trend is broken from 2003 to 2008 , although this can also be interpreted as a tendency of readdressing national politics for solving global and European problems. It remains to be seen if this trend will continue in the following years.

\section{Horizontal Europeanization}

'Mutual observation' and 'discursive exchange' are our two indicators for the horizontal Europeanization of public spheres. They focus on the cross-border flow of opinions and arguments, and thereby show to what extent the public debates in the member states are integrated in a common European discourse. This dimension was measured by considering the range of countries being mentioned in the articles as well as the scope of foreign speakers, being quoted either directly or indirectly. National references and national speakers are those that are explicitly named or implicitly deducible from the content of the article and relate to the domestic origin of the regional newspaper. References to European member states and EU speakers relate to European nations that are EU members and therefore part of the community at the particular point of news reporting. Beside US references all other foreign countries or their speakers are subsumed as "other foreign countries". Transnational speakers are those who - like Ban Ki-Moon, the Secretary-General of the UN - work for inter- and transnational organizations and are not explicitly connected to their national origin. 
Figure 4. References to countries $(n=20,025)$

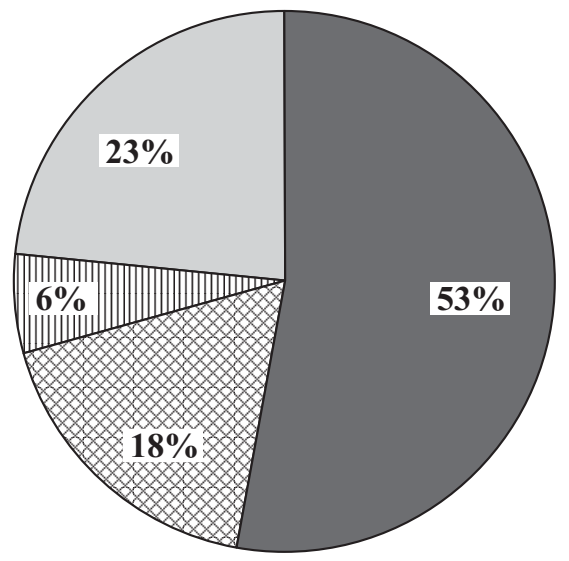

National references

References to European
member states

IIII Reference to the US

Reference to other foreign countries

Figure 4 demonstrates the already mentioned dominance of national references. Also regarding geographic orientations within the articles, our data reveals that $53 \%$ of the country references relate to the home nation of the regional newspapers; $18 \%$ of the mentioned countries are European countries, $6 \%$ relate to the US, and $23 \%$ to other foreign countries. However, comparing the level of vertical transnationalization we can notice that the level of horizontal transnationalization is less dominated by domestic references (around 50\% rather than 70\%). In other words: Regional news coverage can be considered to be quite transnational - including all the abovementioned topics.

Figure 5. References to countries over time $(n=20,025)$

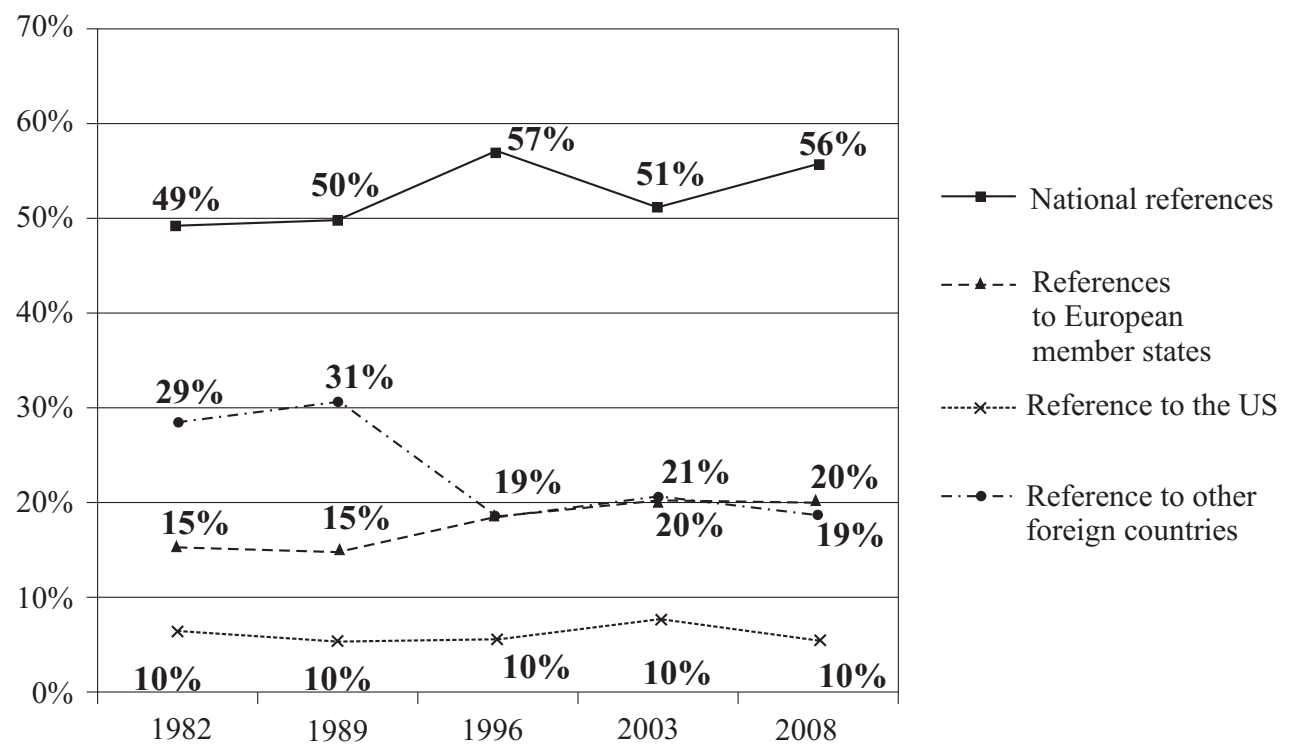


Referring to figure 5, we can conclude that there has always been a considerable proportion of references to European member states, independent from the Union's extent. Whereas reporting about the EC member states in figure 1982 encompassed 10 member states, reporting in 2008 already considered 25 EU member states. The leap from 15 to $19 \%$ probably mirrors the functional consolidation of the European Union by the Maastricht treaty, which resulted in a growing general attention for other member states. Regarding the continuous extension of the Union, it is no wonder that at the same time the high level of references to other foreign countries decreases from 31 to $19 \%$. Furthermore, it is also related to the political situation of the cold war and the attention paid to the Eastern Bloc states until the fall of the iron curtain at the end of 1980s. Post-9/11 news coverage and an increasing global activity of North America in the fight against international terrorism might have resulted in the peak of US references in 2003. But looking at the trend of domestic references over time, it is fluctuating and difficult to interpret: We can see a peak of $57 \%$ in 1996, and a trend of increasing national references from 2003 to 2008. If this trend continues in future and in case it would be accompanied by lower EU monitoring and sinking references to EU member states, we would term it "re-nationalization"; in that sense it would indicate an upcoming limitation of news coverage to national discourses at the expense of a wider transnational discourse.

Table 4

References to countries in different regional newspapers from 1982 to 2008 (lowest and highest percentage is marked)

\begin{tabular}{|c|c|c|c|c|c|c|c|}
\hline & $\begin{array}{c}\text { Westdt. } \\
\text { Allgem. } \\
\text { Zeitung } \\
\text { (D) }\end{array}$ & $\begin{array}{c}\text { Ouest } \\
\text { France } \\
\text { (F) }\end{array}$ & $\begin{array}{c}\text { Manchester } \\
\text { Evening } \\
\text { News } \\
\text { (GB) }\end{array}$ & $\begin{array}{c}\text { Kleine } \\
\text { Zeitun } \\
\text { g (Ö) }\end{array}$ & $\begin{array}{l}\text { Jydske } \\
\text { Vestkyst } \\
\text { en (DK) }\end{array}$ & $\begin{array}{c}\text { Dziennik } \\
\text { Zachodni } \\
\text { (PL) }\end{array}$ & Total \\
\hline \begin{tabular}{|ll}
$\begin{array}{l}\text { National } \\
\text { ences }\end{array}$ & refer- \\
\end{tabular} & $\begin{array}{c}48 \% \\
(1,412)\end{array}$ & $\begin{array}{c}42 \% \\
(1,619)\end{array}$ & $\begin{array}{c}67 \% \\
(2,495)\end{array}$ & $\begin{array}{c}46 \% \\
(1,147)\end{array}$ & $\begin{array}{c}59 \% \\
(2,529)\end{array}$ & $\begin{array}{c}51 \% \\
(1,382)\end{array}$ & 10,584 \\
\hline $\begin{array}{l}\text { References to Euro- } \\
\text { pean nations }\end{array}$ & $\begin{array}{l}18 \% \\
(531)\end{array}$ & $\begin{array}{l}19 \% \\
(747)\end{array}$ & $\begin{array}{l}10 \% \\
(375)\end{array}$ & $\begin{array}{l}23 \% \\
(566)\end{array}$ & $\begin{array}{l}17 \% \\
(737)\end{array}$ & $\begin{array}{l}23 \% \\
(632)\end{array}$ & 3,588 \\
\hline $\begin{array}{l}\text { References to the } \\
\text { US }\end{array}$ & $\begin{array}{l}7 \% \\
(210)\end{array}$ & $\begin{array}{c}7 \% \\
(249)\end{array}$ & $\begin{array}{l}7 \% \\
(277)\end{array}$ & $\begin{array}{l}6 \% \\
(154)\end{array}$ & $\begin{array}{c}5 \% \\
(191)\end{array}$ & $\begin{array}{c}5 \% \\
(125)\end{array}$ & 1,206 \\
\hline $\begin{array}{l}\text { References to other } \\
\text { foreign countries }\end{array}$ & $\begin{array}{l}27 \% \\
(781)\end{array}$ & $\begin{array}{c}32 \% \\
(1,228)\end{array}$ & $\begin{array}{l}16 \% \\
(604)\end{array}$ & $\begin{array}{l}25 \% \\
(633)\end{array}$ & $\begin{array}{l}19 \% \\
(817)\end{array}$ & $\begin{array}{l}21 \% \\
(584)\end{array}$ & 4,647 \\
\hline Total & $\begin{array}{c}2,934 \\
(100 \%)\end{array}$ & $\begin{array}{l}3,843 \\
(100 \%)\end{array}$ & $\begin{array}{c}3,751 \\
(100 \%)\end{array}$ & $\begin{array}{c}2,500 \\
(100 \%)\end{array}$ & $\begin{array}{c}4,274 \\
(100 \%)\end{array}$ & $\begin{array}{c}2,723 \\
(100 \%)\end{array}$ & $\begin{array}{l}20,025 \\
(100 \%)\end{array}$ \\
\hline
\end{tabular}

Although the Danish Jydske Vestkysten is also marked by a higher proportion of national references than transnational ones, it is again the news coverage of the Manchester Evening News (weak transnationalization) and of the Ouest France (strong transnationalization) that mark the opposite poles of the statistical distribution. On the one hand, the euro-sceptical attitude and the insular position of Great 
Britain go along with low levels of attention towards other European countries $(10 \%)$. On the other hand, France pays attention to other European countries (19\%), but even more frequently to other non-European countries (32\%). Within our sample, interestingly it is the newspapers of the newest EU member states, Poland (2004) and Austria (1995), that monitor their European neighbours intensely. With the exception of Great Britain, the level of horizontal Europeanization among the long-term members France (19\%), Germany (18\%) and Denmark $(17 \%)$ is on a similar level. The proportion of references to the US in all regional papers is on the same level, varying from 5 to $7 \%$. This low amount of US references in a British newspaper is quite surprising, considering the Anglo-Saxon geo-linguistic and political space.

A second indicator for a transnational discourse is the origin of the speakers quoted within the articles. If actors, irrespective of their function in society, from other, in particular other European countries, are directly or indirectly quoted, we could assume an integrated discourse culture among the European member states.

\section{Figure 6. Origin of quoted speakers $(n=18,900)$}

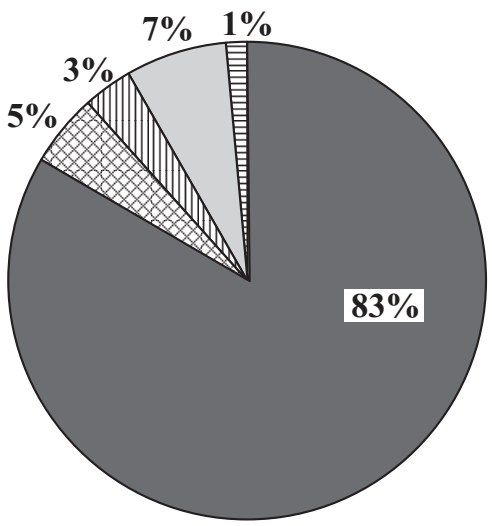

National speakers

(EU-)European speakers

血 (US-)American speakers

Speakers from other nations

Transnational speakers

With a proportion of $83 \%$ of national actors among all quoted actors, figure 6 illustrates the strongest dominance of national references. We can notice a 50-50 relation regarding national and transnational country references, a 70 to 30 relation regarding national and transnational institutional references, and a 80 to 20 relation when it comes to speakers as sources within the articles in our sample. Speakers from other non-European countries are quoted only in $7 \%$, and speakers from European countries in only $5 \%$ of the cases. American and transnational speakers are completely marginalized. When analysing our data over time, there are slight fluctuations from one year to the next: But in the long run the tendency remains stable on each level. Comparing the proportions among the analysed newpapers, it is the Kleine Zeitung from Austria that with $72 \%$ has the lowest level of national speakers for the benefit of a higher share of European speakers (11\%) and speakers from the US (5\%). Likewise to its country references it is Ouest France, that with a share of $12 \%$ speakers from other nations turned out to cover the most transnationalized discourse beyond European reach. 
Summarizing these results regarding a horizontal Europeanization of regional public spheres, we can conclude an increase in mutual observation, but little discursive exchange: regional newspaper reporting pays attention to other European countries, but speakers from these countries are hardly represented at all. Related to country references, we can state a re-nationalization trend between 2003 and 2008 since national references increase at the expense of all references to other foreign countries. However, on the one hand we have to consider that over this period more and more foreign states (many states from the former Eastern Bloc) became part of the group of EU states, and that the peak to other states in 1989 might especially result in the special Eastern political transformation situation at that time. On the other hand, between 2003 and 2008 references to EU member states also maintained a consistent level. Therefore, our data might also indicate an intense internal European discourse about solving the crisis and not a pure re-nationalisation. Future content analyses have to be undertaken for a deeper understanding of this matter.

\section{European identification}

Our third and final analytical dimension relates to the construction of communities as they are articulated in the regional newspapers. A precondition for the self-perception as part of the European community is a collective identity, expressed in statements as "We, the Europeans" or at least the existence of a topos like "the Europeans" within the journalistic content. Hence, we distinguish between the dimension of identification "we-references" and "collective identities" as the significant others in the public discourse.

Figure 7. We-References over time $(n=13,969)$

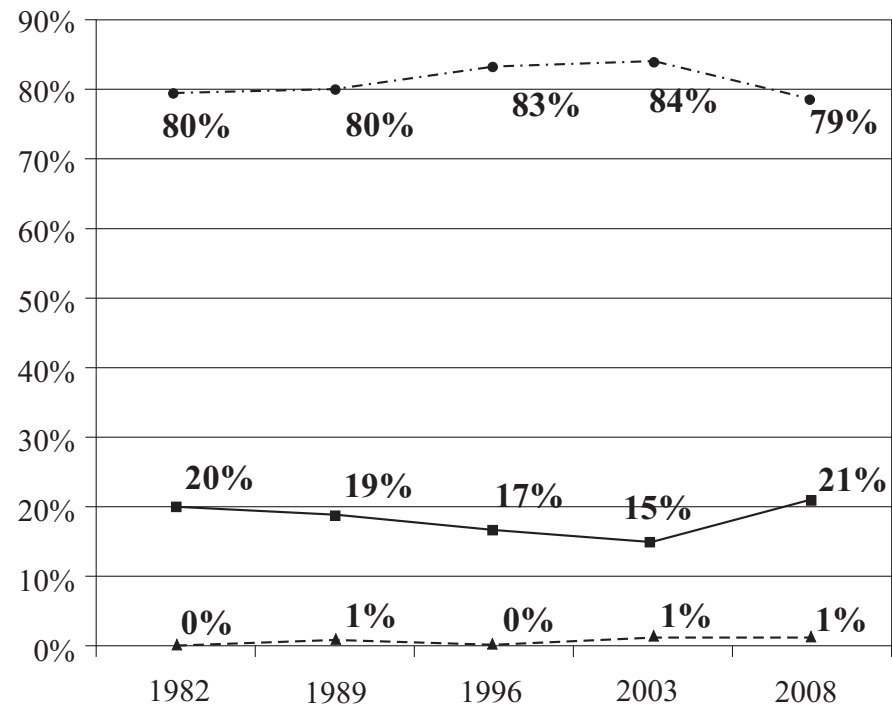

$\longrightarrow$ National We

--^-- European We

-.•. Exclusive We 
By analysing we-references across time, it becomes obvious that in most regional newspapers we find exclusive we-references on quite a stable level at an average of $81 \%$. "Exclusive we-references" means that the author of the article or an actor who is quoted in the article identifies him- or herself with a certain community, not including the reader (e.g. "We, the trade union" or "We, the homosexuals"). National we-references are at an average level of $18 \%$, and increased in the years between 2003 and 2008 from 15 to $21 \%$. Regarding our main focus of interest, the amount of European we-references, we have to state a constant level of negligible 0 to $1 \%$.

Comparing the proportions among our analysed newpapers, it is remarkable that besides exclusive we-references the Ouest France shows a lot of national we-references $(20 \%)$, and with $2 \%$ above-average European we-references.

Figure 8. References to collective identities $(n=2,674)$

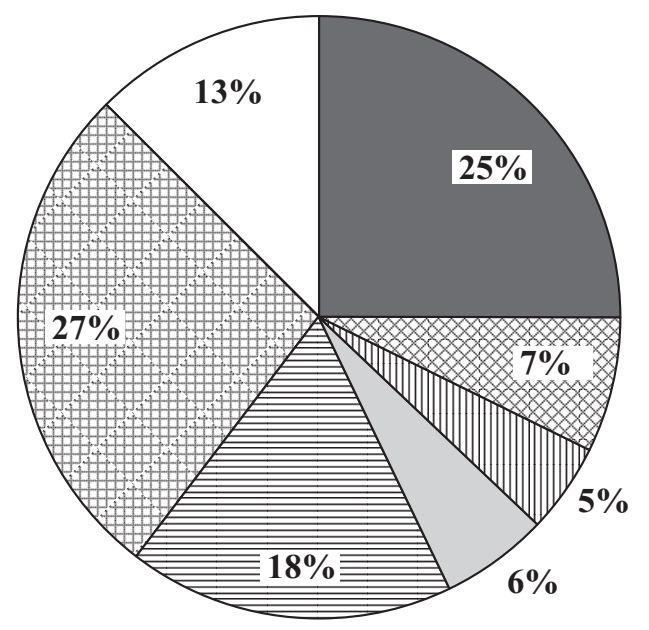

My own nation

The West

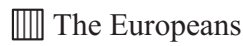

The Americans

The other EU-members (single)

The other nations (single)

Other transnational communities

As presented in figure 8, there is a remarkable distribution of different collective identities in our sample. Addressing the own nation as a community (e.g. "The Germans" in the Westdeutsche Allgemeine Zeitung) is on the one hand as common $(25 \%)$ as addressing other non-western and non-European nations in the same way (27\%). Other European member states are in $18 \%$ of the cases individually addressed, whereas "The Europeans" as a collective is only mentioned in 5\% of the cases. "The West" as a community is named in 7\%, and "The Americans" in $6 \%$ of the cases. Other transnational communities, for example communities beyond the national frame like religious or ethnic groups, are referenced to in $12 \%$ of the cases.

In figure 9 we can notice at first glance that the proportions for all references to collective identities are quite fluctuant over time. Nonetheless, there are some remarkable tendencies. References to the own nation are fluctuant, but constantly rising in the long run (from 21 to $35 \%$ ). References to the West as an identifiable collective are fluctuant, but constantly decreasing (from 13 to 3\%). Already starting 
Figure 9. References to collective identities over time $(n=2,674)$

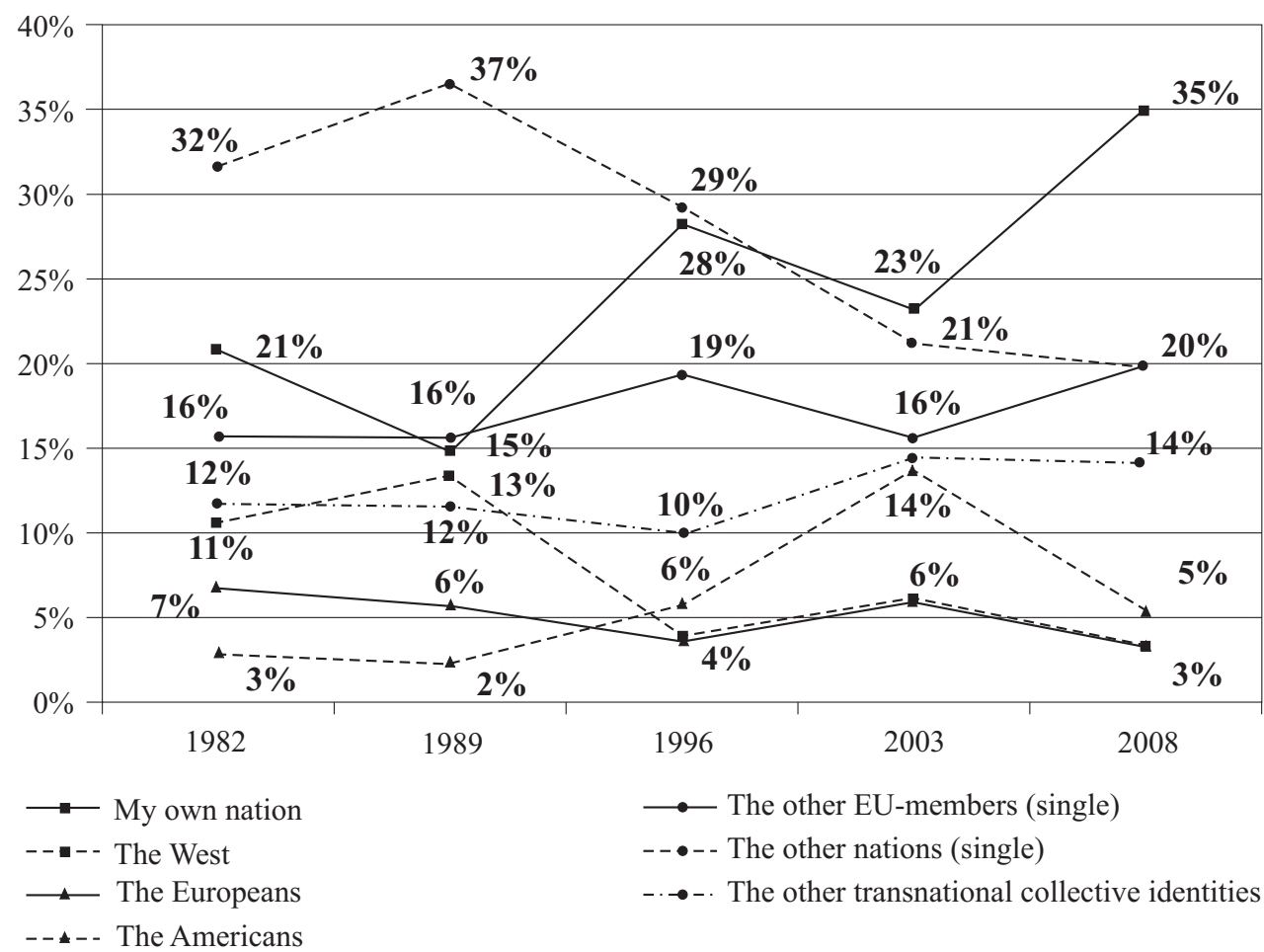

on a low level, and then likewise slowly decreasing, are references to "the Europeans" (from 7 to 3\%), whereas single European member states are more frequently addressed as collectives (from 16 to $20 \%$ ). As in some of the other dimensions, we can also see here in the collective dimension that references to "the Americans" are most frequently made in the post 9/11 era in the year 2003. In 2008 the level of references however goes back to the pre-9/11 level of 1996. Regarding references to collective identities to other nations, we can see a major decrease from 37 to $20 \%$. This tendency might be seen as complementing the decrease of references to other nations that we have already seen for the country references in figure 5. Here we have explained the decreasing interest to other nations as a consequence of the on-going European integration process and the admission of more member states. In addition, we have to keep in mind the collapse of the Eastern Bloc in 1989 resulting in dissolution of the Western and Eastern spheres as closed political entities. References to other transnational collective identities are more or less stable at between 10 and $14 \%$.

Summarizing the results regarding European identification within the regional press coverage, we can conclude that there is hardly any evidence of an explicitly expressed shared European identification: there is no growing common reference to "We as European". To the contrary, the collective "the European" even seems to lose 
weight in the public discourse. But it can be noted that Europe is instead perceived in another way, namely identified by the single European countries that are increasingly addressed as collectives.

\section{Conclusions}

The following questions formed the starting point of our analysis of regional newspaper coverage: Do we find in European regional press the same, however contested trend of Europeanization as we know it from other print media outlets? Or are there other trends like trans- or (re-) nationalization? And can we link this in a certain way to the characteristic of the regional newspapers as "reporter"? Summarizing our presented research, we can conclude an ambivalent result. A vertical Europeanization can be observed until 2003 through an increasing visibility of EU institutions that is referred to at a middle-range level, whereas explicitly European policies are quite rarely addressed in the regional news coverage. The latter is hardly surprising because it seems to be the result of the already mentioned pragmatic choices of journalists in regional papers as "reporters" keeping their broad audience and their interests in mind. Maybe also unsurprisingly, we could show that France and Great Britain often constitute the opposite ends of the scale of Europeanization, paralleling to a certain extent the countries' respectively rather eurosceptic or europhile positions.

From starting already at a quite visible level, a slight tendency of horizontal Europeanization, i.e. a growing focus on EU countries, can be found up to the year 2003. In contrast to Great Britain, the more recently joined members Poland and Austria show the strongest horizontal tendencies for Europeanization. However, when it comes to the possibility of being quoted in the news coverage, speakers from other European countries are mainly absent. This fact also remains stable over time. It can be explained by the process of newsgathering within regional outlets: due to financially limited resources regional papers usually cannot employ foreign correspondents to get access to international actors as sources and therefore mostly rely on news agencies... Even less existent are indicators for a European identification. European "we-references" are nearly non-existent, and "the Europeans" are losing weight over time. However, what is obvious instead is that references to the single EU members as collectives are on a good middle-range level and increase over time.

Interestingly, these elementary results are completely in line with our previous content analyses of quality and boulevard newspapers (Hepp et al., 2012:63-83). We also found a rising attention for EU politics up to the year 2003, and a flattening vertical Europeanization in 2008. We could already observe a constant interest in European neighbours as a sign of a stable horizontal Europeanization, and only minimal evidence of a European identification. However, what the analysis of the regional papers could furthermore impressively reveal is that Europe as community is founded and is discussed on the basis of still existing and very strong European na- 
tions. Especially between 2003 and 2008, the own nation and 'the national' as point of reference in the news coverage became an important matter in all newspapers; in our longitudinal research it increased at the time the financial crisis started in Europe. As already argued, further research is needed to interpret this data in an appropriate way: Is it just an indicator of a re-nationalisation? Or do we have a more complex pattern whereby the relation between the own nation, other European nations, and the EU is re-negotiated? Both would have resulted in a higher number of national references in 2008, but the outcome would be quite a different one. Our content analysis of 2013 will at least provide information about further developments and give us the chance to discuss this matter more deeply.

Finally, increasing national references in the news coverage in the context of the EU and Europe is not inevitably an opposition or even contradiction to the process of Europeanization, nor is it dysfunctional for European integration. And as Georg Vobruba (2013) argues, the "Eurozone crisis might not be a deadly challenge to the whole European construct, but rather become a further step towards a European society", since it "set off a new dynamic of people's action and institution building" (Vobruba, 2012:276). Therefore, we are confronted with complex processes of struggle and re-negotiation between European countries that are not contrary to a step-by-step constitution of a European society but part of it. Here, Vobruba reminds us of the classical sociological analysis by Georg Simmel that demonstrated how far the national society was also constructed by conflict. It remains a subject for further research whether this ambivalent trend between 2003 and 2008 will continue and actually result in a re-nationalisation or in a more intense Europeanization.

\section{References}

Eriksen, E. O., Fossum, J. E. (eds) (2000), Democracy in the European Union: Integration through Deliberation?, Abingdon: Routledge.

Gripsrud, J. (2007), “Television and the European Public Sphere”, European Journal of Communication 22(4), 479-492.

Habermas, J. (1998), Between Facts and Norms: Contributions to a Discourse Theory of Law and Democracy, Cambridge: MIT Press.

Habermas, J. (2000), The Inclusion of the Other: Studies in Political Theory, Cambridge: MIT Press.

Habermas, J. (2001), The Postnational Constellation: Political Essays, Cambridge: MIT Press.

Heikkilä, H., Kunelius, R. (2008), “Ambivalent ambassadors and realistic reporters: The calling of cosmopolitanism and the seduction of the secular in EU journalism", Journalism 9 (4), 377-397.

Hepp, A. et al. (forthcoming), "Political discourse cultures in Europe: Explaining the multi-segmentation of the European public sphere", in: H. Rothgang, S. Schneider (eds), Explaining transformations of the state, Basingstoke: Palgrave Macmillan.

Hepp, A. et al. (2012), Politische Diskurskulturen in Europa: die Mehrfachsegmentierung europäischer Öffentlichkeit, Wiesbaden: VS Verlag. 
Koopmans, R., Erbe, J. (2004), “Towards a European public sphere? Vertical and horizontal dimensions of Europeanized political communication", Innovation: The European Journal of Social Science Research 17(2), 97-118.

Koopmans, R., Statham, P. (eds.) (2010), The making of a European public sphere: Media discourse and political contention, Cambridge: Cambridge UP.

Nitoiu, C. (2013), “The European Public Sphere: Myth, Reality or Aspiration?", Political Studies Review 11(1), 26-38.

Peters, B. (2008), Public Deliberation and Public Culture, Basingstoke: Palgrave.

Risse, T. (2010), A community of Europeans? Transnational identities and public spheres, New York: Cornell UP.

Roose, J. (2008), "In nächster Nähe so fern. Grenzübergreifende Lokal- und Regionalberichterstattung als Aspekt von europäischer Integration", Zeitschrift für Soziologie 37(4), 321-341.

Schäfer, M. S., Schmidt, A., Zeckau, T. (2012), “Grenzüberschreitende Ungleichheiten. Eine qualitative Analyse der Medienberichterstattung in drei deutschen Grenzregionen", in: C. Stegbauer (ed.), Ungleichheit: medien- und kommunikationssoziologische Perspektiven, Wiesbaden: Springer VS, 101-120.

Schlesinger, P. (1999), "Changing Spaces of Political Communication: The Case of the European Union”, Political Communication 16(3), 263-279.

Schlesinger, P., Kevin, D. (2000), "Can the European Union Become a Sphere of Publics?", in: E. O. Eriksen, J. E. Fossum (eds), Democracy in the European Union: Integration through Deliberation?, Abingdon: Routledge, 206-229.

Trenz, H.-J. (2004), “Media Coverage on European Governance: Exploring the European Public Sphere in National Quality Newspapers", European Journal of Communication 19(3), 291-319.

van Noije, L. (2010), “The European paradox: A communication deficit as long as European integration steals the headlines", European Journal of Communication 25(3), 259-272.

Veltri, G. A. (2012), "Information flows and centrality among elite European newspapers", European Journal of Communication 27(4), 354-375.

Vobruba, G. (2012), "The Social Construction of the European Society", in: H. F. Dahms, L. Hazelrigg (eds), Theorizing Modern Society as a Dynamic Process, Bingley: Emerald, 263-279.

Vobruba, G. (2013), “The Eurozone crisis: no way back", openDemocracy (15.03.2013), http:/ / www.opendemocracy.net/georg-vobruba/eurozone-crisis-no-way-back (accessed: 01.10.2013).

Wessler, H. et al. (2008), Transnationalization of Public Spheres, Basingstoke [u.a.]: Palgrave Macmillan. 

Knut De Swert

ASCoR, University of Amsterdam, the Netherlands

Julie De Smedt

$\mathrm{M}^{2} \mathrm{P}$, University of Antwerp, Belgium

\section{Hosting Europe, Covering Europe? Domestication in the EU-Coverage on Belgian Television News (2003-2012)}

Ample research has shown that across Europe, television news coverage on the European Union is relatively limited, especially compared to the political and economical significance of the EU (Gleisner \& de Vreese, 2005; de Vreese \& Boomgaarden, 2006). Moreover, when covered, EU related news stories are generally focused on specific, key-events (de Vreese, 2001). While European summits are almost guaranteed to receive at least some news media attention, this is not necessarily the case for other (regular) EU-activities or European institutional actors. General EU policy related news coverage is scarce, and even European elections do not get much attention by media, as they are considered secondary elections by the people, national political actors and news makers (see for an extensive, comparative study: de Vreese et al., 2006). On top of that, large institutional actors like the (members of) the European parliament only get minor attention. For many observers, this is an unfortunate situation, which does not sync with the overall importance of EU politics. News coverage on all aspects of the European Union is crucial for the public to acquire enough knowledge about and understanding of the EU, and for the institutions themselves to be recognized by the people as a relevant political decision level and to be evaluated more positively by them. Increasing the legitimacy of the EU has proved to be a necessary and continuous priority for the EU.

Even if Belgium basically hosts the European Union (EU) in its capital Brussels, news coverage in Belgium is not spared from this trend. The scarce scientific research done on this matter shows that Belgian television news does not cover European news stories more frequently and/or extensively than other European countries. On the contrary, a study based on news from 2006-2007 shows that news broadcasts in countries like Germany and Italy cover Europe considerably more than Belgian broadcasters do (De Swert, 2009; 2011).

Apparently, the geographical proximity of the EU in the heart of the country does not seem to make much of a difference. For several reasons, that is a strange observation. News value research (Galtung \& Ruge, 1967; Chang, Shoemaker \& Brendlinger, 1987; Harcup \& O'Neill, 2001) clearly stresses the importance of geographical proximity as one of the drivers of news worthiness (see also Stępińska et al., 2013). Moreover, the closeness of the EU institutions should also make it logisti- 
cally easier for reporters to cover EU stories, since all the important news sources are available right at hand. Finally, there is the obtrusiveness of the EU in and around Brussels. Hosting the EU (which also has its benefits for the city and the country) namely impacts the local society quite severely from time to time. Whether it is street destruction by angry farmers or fishermen during their frequent protest marches, traffic jam because of increased safety measures for EU meetings or excitement about the arrival of international big shots at Brussels Airport, the presence of the EU institutions in Brussels seems to bring along plenty of occasions for EU-related news stories worth covering for Belgian television news.

Despite these elements, the aforementioned study seven years ago could not find more coverage in Belgium than in other EU countries. The reasons for this unexpected result were not clear from this study. Therefore this chapter wants to reconnect to this question, utilizing a rich dataset of content-coded television news of the Belgian ${ }^{1}$ public broadcaster VRT and the Belgian commercial broadcaster VTM. This dataset is provided by the Television News Archive of the Media Policy Research Centre, a scientific initiative supported by the Flemish government (www.steunpuntmedia.be). This unique archive contains all main prime time television news broadcasts of the public and private broadcaster in Flanders (Belgium) since 2003. At the moment, it consists out of more than 150,000 news items, each of them coded and on-line available in streaming video for research purposes. This dataset is not only longitudinal and large, which accommodates urgent calls for such research by e.g. Riffe et al. (1994) and Wouters (2009), it also includes very recent material. This is important, first of all since especially the economic crisis has boosted EU-relevance in the news considerably in the past few years. But secondly, also Belgian links to the EU have formally increased in this time period, mainly by the appointment of the Belgian ex-first minister Herman Van Rompuy as the president of the European Union.

\section{Domestication}

Both geographical proximity and the presence of elites with the nationality of the country of broadcast can be considered natural elements of domestication. Domestication of foreign news, in this case EU news stories, refers to the process by which newsmakers try to make this intrinsically 'distant' news more proximate to the

\footnotetext{
${ }^{1}$ In this chapter, when Belgium is mentioned, we mean the Dutch-speaking part of Belgium. This northern part of the country has most inhabitants and surrounds Brussels, which means the impact of the EU is largest on this part. Since media systems in Belgium are completely segregated by language, we need to make choices. Since there are rich data available for the Dutch-speaking part of the country, and not for the French-speaking part, we opted to include only the Dutch-speaking part. It should be mentioned though, that in the 2006-2007 study the French-speaking news broadcasters were included, and they showed a higher amount of coverage of the EU than the Dutch-speaking broadcasters (De Swert, 2009).
} 
viewer by linking the news to the home country in one way or another (Clausen, 2004; Uce, Schueremans \& De Swert, 2004). Thus, domestication of EU news is one path newsmakers can follow to ensure a proper stream of EU related information in television news without losing viewers because of disinterest. In some cases this domestication is forced by creating or emphasizing links between the foreign news subject and the home country (e.g. by interviewing an expat national present in the country which is covered). In other cases, like the one discussed in this chapter, 'natural' domestication elements are present, which are totally unrelated to journalistic influences. However, the decision to use these links of course remains in the hands of the news makers themselves.

Taking all that into account, this study has three main research questions:

RQ1: How much coverage is there about the EU in Belgian television news? What are the characteristics of this coverage (topics and actors).

RQ2: How has coverage on Europe evolved in Belgian television news over de last ten years?

RQ3: To what extent does (natural) domestication of news about the European Union drive news coverage on the European Union? Which elements of domestication are most prominent?

To answer these research questions, we will make use of the above described dataset of Belgian television news casts. From the approximately 150,000 news items, we will identify the items about the EU, and investigate them in more detail using the existing coding of the Television News Archive as a starting point, linking them to the specific topics, contexts and forms of domestication. The basic coding of this giant dataset is done by dozens of coders of a period of ten years. The variables used in this chapter are coded with sufficient inter-coder reliability (for an extensive report on inter-coder reliability of the dataset see Wouters, De Smedt \& De Swert, 2013).

\section{European Union-related coverage in Belgian television news}

Our first two research questions are very descriptive in nature, referring to the amount of coverage on the EU in Belgian television news and the evolution of this (amount of) coverage through the years. Graph 1 provides an overview of the relative amount of attention for EU-related news stories in Belgian television news (public and commercial broadcaster combined) between 2003 and 2012, based on figures aggregated per quarter. First of all, from this graph it becomes clear that the time period in which the aforementioned comparative data were situated (end of 2006-beginning of 2007) was a time period with exceptionally low attention for the EU in Belgian television news. The present study does not provide information about other countries, so it is up to future research to find out if similar evolutions in attention for EU-related news can be found in other countries. For as far as Belgium is concerned, we can conclude that there is a quite low, but steady amount of cover- 
age on the EU at all times (2.3 percent, which corresponds to about one news item about the EU per broadcaster every two days, or on average 48 seconds of EU-related news on a daily basis, calculated over the full time period of ten years). Another interesting conclusion is that since 2009, there is a trend towards a higher share of EU-related news coverage, with a peek in the end of 2011.

Graph 1. \% European policy-related news in television news in Flanders (public and commercial channel together, weighted by duration of news items)

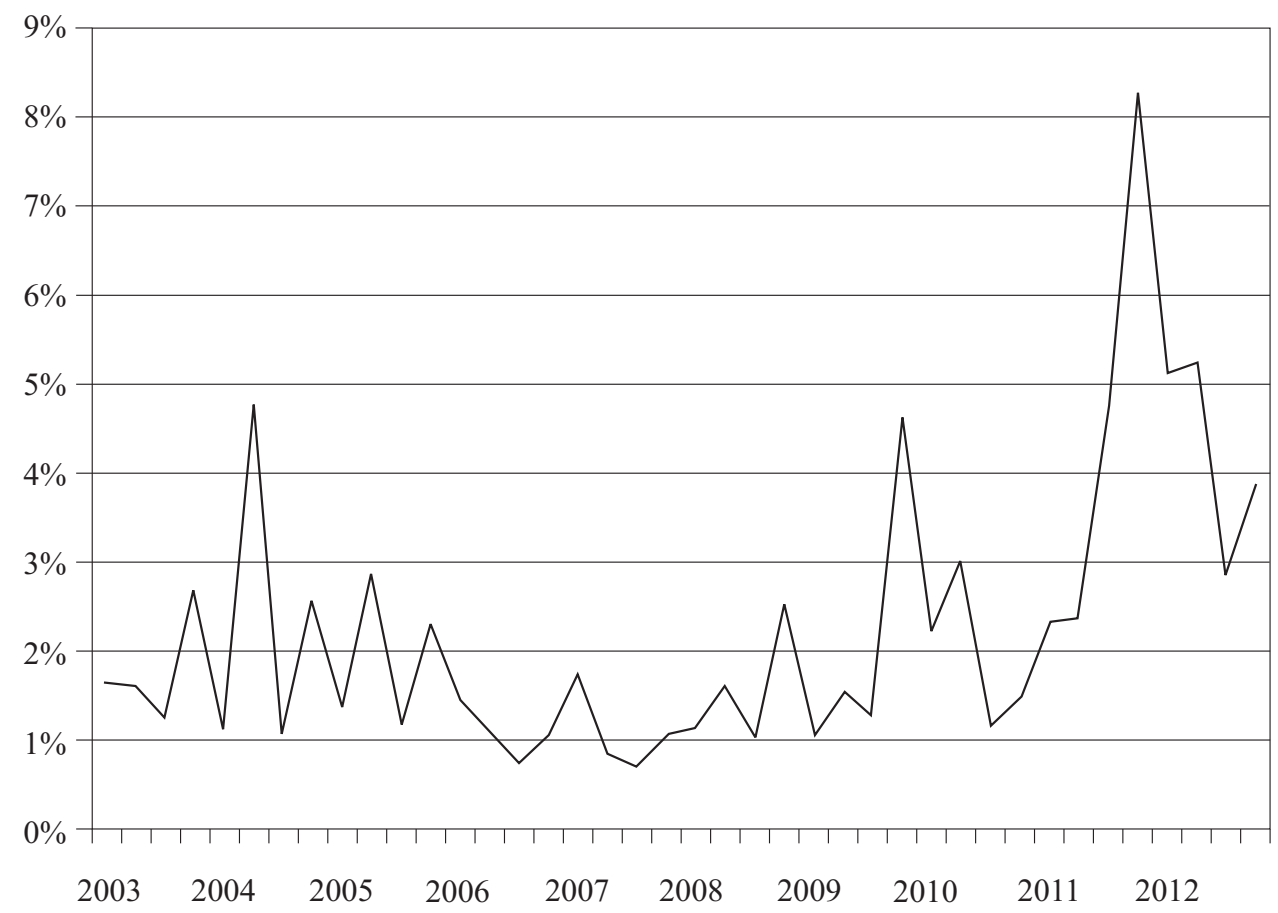

Where it is usually fairly difficult to account for the different topics EU news coverage is about in television news because of the small amount of EU news in the first place, the present data set provides an interesting opportunity to get a reliable indication of the most and least covered topics in EU news. Gauged over the full time period (2003-2012), Economy \& Finances clearly tops the list with more than 85.000 seconds of attention on Belgian television news in that ten years time period (See Table 1). More than one third (34.5 percent) of all news attention for the EU was about economical or financial issues. International relations (including involvement in international conflicts, but also diplomacy and aid) is a solid second, while internal politics of the EU completes the top three. Other topics which are very important policy domains on which the EU has significant political decision power, like agriculture, environment \& energy and consumer protection are covered far less. 
Table 1

Coverage of topics within EU-related news coverage in Belgian television news over the period 2003-2012 (in total amount of seconds and in percentage of all topics), weighted by item duration. $\mathrm{N}=2,734$ news items

\begin{tabular}{|l|c|c||}
\hline \multicolumn{1}{|c|}{ Topic } & $\begin{array}{c}\text { Amount of seconds } \\
\text { of news coverage } \\
\text { (2003-2012) }\end{array}$ & $\begin{array}{c}\text { Percentage of news } \\
\text { coverage (2003-2012) }\end{array}$ \\
\hline Economy \& Finances & 85,240 & 34.5 \\
\hline International relations & 36,489 & 14.7 \\
\hline Politics (Internal EU politics) & 31,244 & 12.6 \\
\hline Environment \& Energy & 17,336 & 7.0 \\
\hline Social issues/Employment & 14,594 & 5.9 \\
\hline Crime & 12,228 & 4.9 \\
\hline Immigration \& Human rights & 10,085 & 4.1 \\
\hline Agriculture & 7,588 & 3.1 \\
\hline Consumer protection & 6,865 & 2.8 \\
\hline Mobility & 6,546 & 2.6 \\
\hline Defense & 2,742 & 1.1 \\
\hline Other topics & 16,421 & 6.6 \\
\hline
\end{tabular}

Even if this topic analysis is done on a large sample (actually, it is the universe of the EU-coverage in all daily main newscasts) over a long period of time, it can still be quite misleading. More in particular, the top position of Economy \& Finances is a quite recent phenomenon. While up till 2007-2008 there were about ten EU-related stories per year about Economy \& Finances, this amount grew in 2008-2009-2010 to about 50 per year, and in 2011 and 2012 this culminated in respectively 266 and 296 news stories involving the EU and a topic related to Economy \& Finances. This means 73 percent of all EU Economy \& Finances news coverage over the complete time period 2003-2012 took place in these two last years.

Linking this trend the previously mentioned factor of the inauguration of Belgian national Herman Van Rompuy as the European President, one might see tentative evidence of the (positive) effect of this natural domestication element on the amount of EU news coverage. However, in graph 2 it is clearly visible that this "Herman Van Rompuy"-effect is only responsible for the peak in 2009, and not for the complete trend. The largest peak in EU-related news (from 2011) seems to be attributable almost solely to the coverage of the economic crisis. While before 2008 economic and financial news did not determine a large part of the total coverage on the EU, it does so since the end of 2008. If all economic and financial news would be taken out of consideration, there would not even be any increase in coverage on the EU. Concerning the prominence of EU-president Herman Van Rompuy, the graph shows that the news items in which he is present do multiply as well when these 
economic and financial EU-issues come up, but they do not cause these peaks in attention for Europe in Belgian television news. For that, the economic and financial news coverage is too dominant.

\section{Graph 2. Amount of European policy-related news items in television news in Flanders (per quarter, public and commercial broadcaster together)}

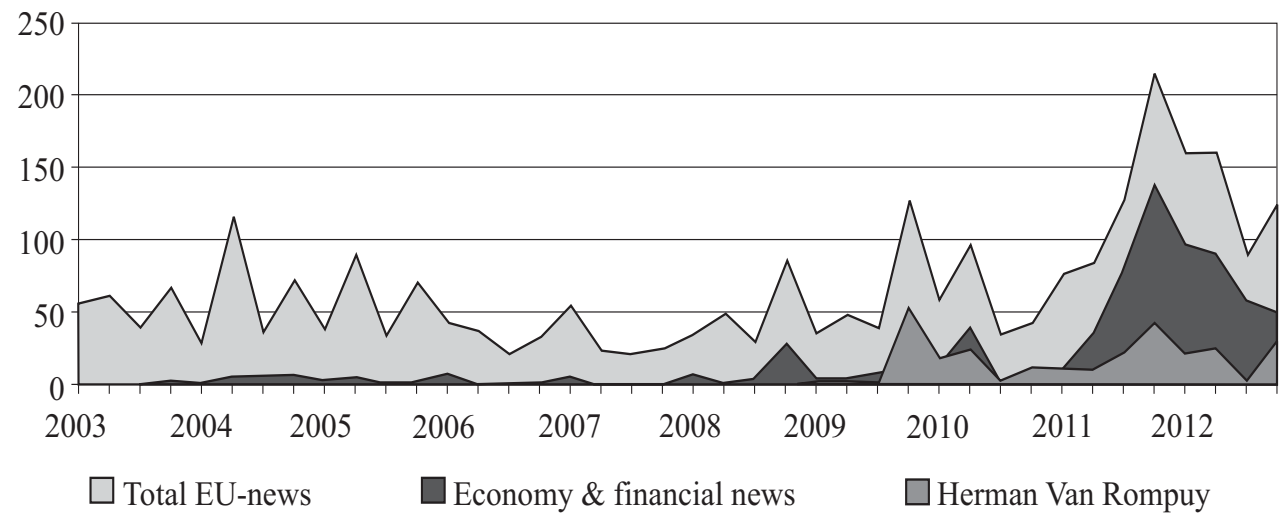

We started off with the idea that several forms of (natural) domestication could be at play for EU coverage in Belgian television news. To be able to get a grasp on the importance of these different forms, we divided all EU-related news items (this was based on the topic coding of the original database, which includes up to three different topic codes for a news item and which includes a short summary of the news item in text) into four categories. The first one is Pure EU-news. This means that the news item is about an EU-related topic and that there is no link whatsoever with Belgium. It is important to know that the simple mentioning of e.g. Brussels like in "Today the EU-council met in Brussels to discuss..." is not coded as domestication, since that is so common place that it does not really link the EU to Belgium, especially not for Belgian TV news viewers. This category of Pure EU-news thus includes news items in which Belgium as a country is not involved, and/or no consequences for Belgium are named explicitly. The second category is a form of domestication: Consequences of the infrastructure and organization of the EU for Belgium (Brussels or Belgium). This includes coverage on the effects of the presence of the EU-institutions and their working on e.g. the house market, traffic situation, city development, infrastructural costs, security effects etc. The third category is about Consequences of EU-related events for Belgium/Brussels. This includes large protests and potential damage and other problems caused by it, special visits, EU celebrations etc. Finally, there is Thematic involvement of Belgium, which means that Belgium is involved as an actor in the EU-topic the news items is about. The most typical case of this is that a news item is made about the impact of EU-policy on Belgian policy, or that in the process of EU decision making the Belgian standpoint is mentioned or expressed by e.g. the Belgian minister in charge of the concerned policy domain. But it also in- 
cludes the appointment of Belgian nationals in EU-institutions. The most prominent example of this is of course the aforementioned appointment of the EU-president Herman Van Rompuy, or the appointment or discussion about the capabilities of the Belgian EU member of the European Commision.

In Graph 3 this division is visualized. The thick black line of the pure EU-news (non-domesticated EU-news) is always higher than the lines of any of the three distinguished domestication forms. Only in the end of 2009, when the appointment of Herman Van Rompuy at EU president was prepared, there were slightly more domesticated news items than purely EU-related news items in the coverage of the two Belgian television news channels.

Graph 3. Amount of European policy-related news items in television news in Flanders (per quarter, public and commercial broadcaster together), $\mathbf{N}=2,734$, divided into Pure EU-news and different forms of domestication

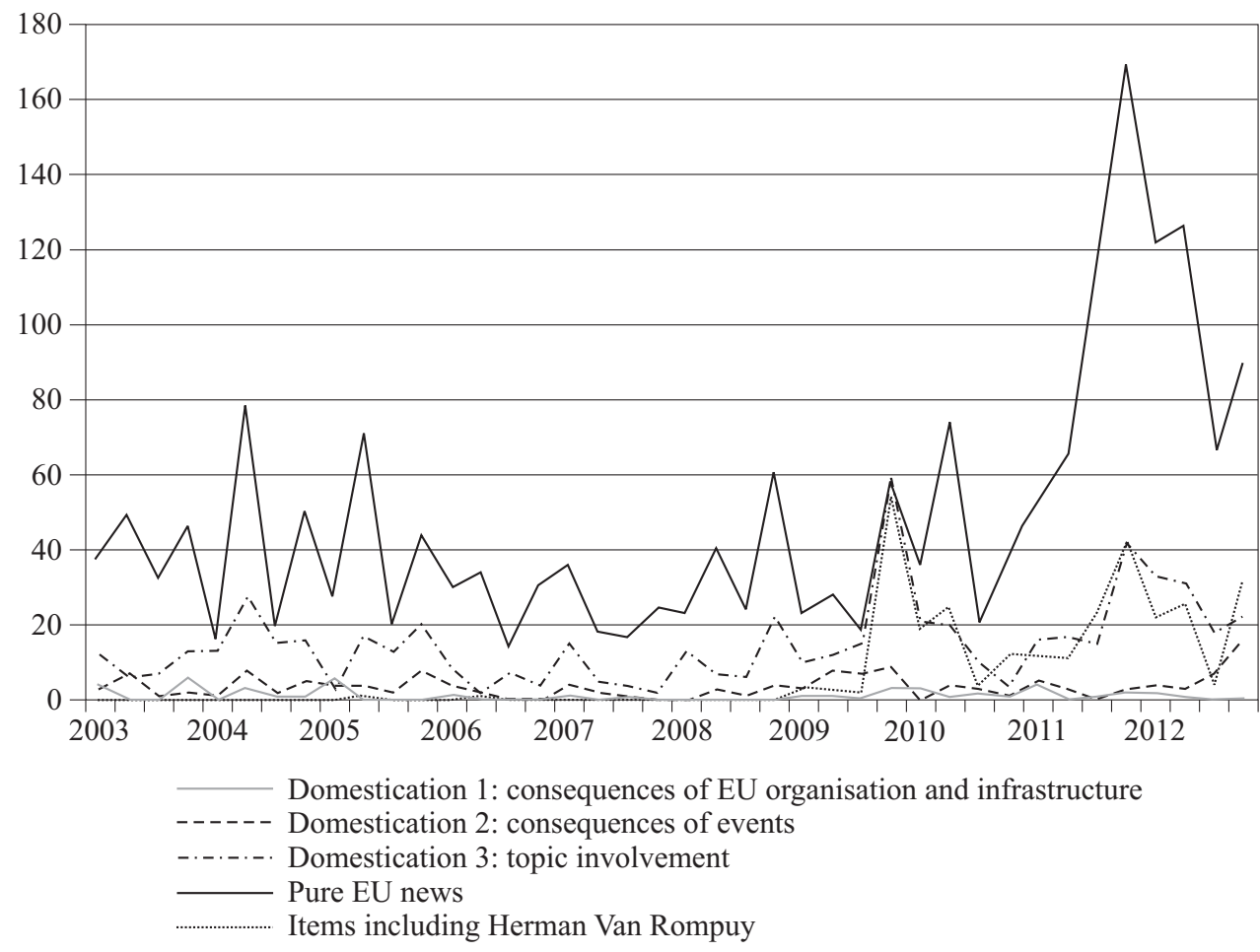

While the three forms of domestication are coded in a mutually exclusive way, it should be noted that the dotted line indicating the amount of items in which Herman Van Rompuy was mentioned or in which he could speak, is not. It is added to try to account for the unique effect of this person only. Following the definition we gave earlier, his appointment as EU-president in 2009 is categorized under Domestication 3: topic (and actor) involvement. 


\section{Herman Van Rompuy: culmination of actor-domestication?}

In Graph 3, Herman Van Rompuy proves to have been quite present in the coverage of Belgian news broadcasters on the EU since his appointment as EU president. This raises more questions. Is the (factual, created or exaggerated) involvement of national actors an important driver of news about Europe? In Table 2, an overview is provided of the function of the actors speaking in news coverage about the EU. An important, but not completely surprising (see e.g. de Vreese et al. 2006) observation here is that most speaking time goes to politicians with the Belgian nationality. The latter can be Belgian national politicians making a statement in the context of an EU-related event or topic, or Belgian politicians who are active in one of the EU institutions (like members of the EP or EC member).

Table 2

Overview of the speaking time of actors by function

(total speaking time $\mathrm{N}=90,943$ and in percentages)

\begin{tabular}{|l|c|c|}
\hline \multicolumn{1}{|c|}{$\begin{array}{c}\text { Actor function } \\
\mathbf{N}=\mathbf{9 0 , 9 4 3} \text { (seconds) }\end{array}$} & $\begin{array}{c}\text { Amount of seconds } \\
\text { speaking time } \\
\text { (2003-2012) }\end{array}$ & $\begin{array}{c}\text { Percentage of all } \\
\text { speaking time on } \\
\text { EU-related coverage } \\
\text { (2003-2012) }\end{array}$ \\
\hline Politician (Belgian nationality) & $\mathbf{2 8 , 0 5 3}$ & 30.8 \\
\hline Politician (non-Belgian national) & 26,050 & 28.6 \\
\hline Expert & 8,352 & 9.2 \\
\hline Citizens & 6,728 & 7.4 \\
\hline Civil society & 5,533 & 6.1 \\
\hline Corporate sources & 4,450 & 4.9 \\
\hline Journalist & 2,038 & 2.2 \\
\hline Protester & 1,423 & 1.6 \\
\hline Others & 8,316 & 9.1 \\
\hline
\end{tabular}

Besides the relatively large share of Belgian voices in EU coverage, the table also reveals a large dominance of (political) elite sources in European news coverage. Experts, citizens, voices representing civil society groups and even corporate sources get allotted a lot less speaking time than the politicians. This indicates that in Belgium, television news about the EU is still mostly about the higher politics, which gives the viewers a low sense of proximity to the content of these news items. This result is in line with the findings about Belgian news coverage on national politics (De Swert, 2011). This general tendency is interesting, but still a bit vague as well. Moreover, it does not clarify the role of e.g. Herman Van Rompuy as a (possibly) exceptional case. The next step is to check whether the actor domestication of EU news coverage in Belgium is just as strongly present in the coverage of the three 
most important EU power centers: the European Parliament, the European Commission and the European Council. Graph 4 presents these results. For each of these power centers, the chairman/ president is shown separately (dark lowest part of the bar charts). ${ }^{2}$

Graph 4. Speaking time for EU actors 2003-2012

per EU institution and by nationality

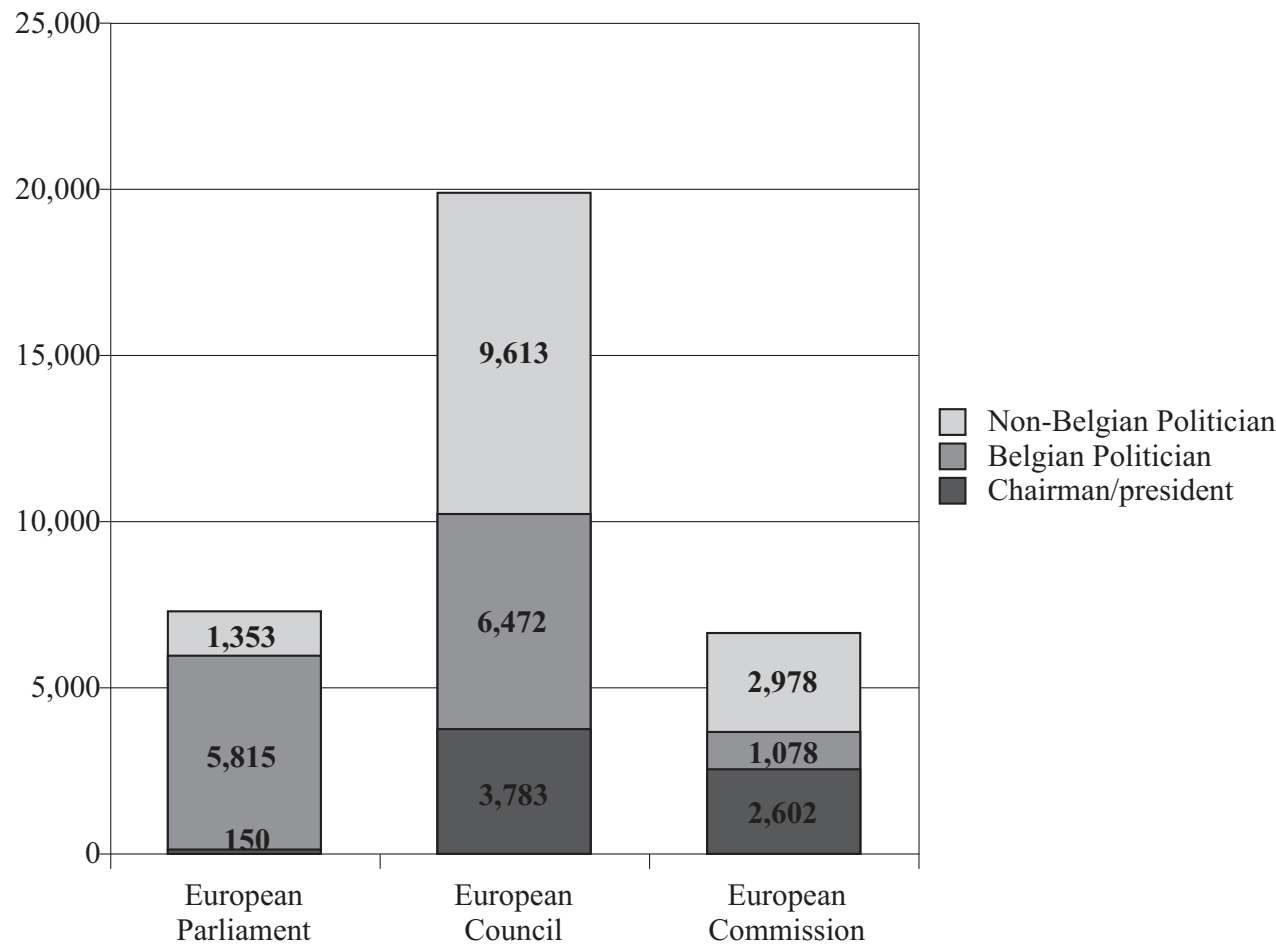

The differences between European Parliament, European Council and European Commission shown in this graph, call for a nuanced view on actor domestication in EU news coverage. While in European Parliament, actor domestication is the norm, this is very much less the case for the European Commission and the European Council. However, also there some tendencies for a preference for links to Belgian nationals can be perceived. The Belgian member of the European Commission (position held by different politicians over the research period) still gets more attention than proportionally would be reasonable for this function (within the whole of the European Commission). The politicians of the European Council (mainly national heads of government), where still all large decisions are made, get far most speak-

2 For the EU Council this is since 2009 Herman Van Rompuy. For the EP these are Pat Cox, Josep Borrell Fontelles, Hans-Gert Pötterig and Jerzy Buzek. For the European commission, these are Romano Prodi and José Manuel Barrosso. 
ing time on EU-related topics. Belgian prime ministers are taking up a large share of this, but since 2009, the president of the EU does so as well. Since no comparison can be made with any previous presidents, it is hard to say at this point if this successful exposure in Belgian television news is due to a "fellow-country-man" effect, or whether this is rather a sort of chancellor bonus, like many leaders enjoy in news media coverage on all political levels (De Swert, 2011).

\section{Conclusions}

First of all, the account made in this chapter confirms that EU-related news coverage is not highly present in Belgian television news. Previous research indicates that in most other European countries similar EU coverage is similarly limited, and most observers deem this problematic for European democracy. If one would start from a full news standard perspective (Zaller, 2003:112-116), the importance of the EU policy level would justify considerably higher amounts of attention in the media. That level of attention is not reached anywhere. It may therefore be at least a concern to explain why this is the case, what the characteristics are of the EU news that does receive proper coverage, and what the role of possible domestication factors could be. This chapter tried to profit from a window of opportunity to do this for Belgium. The country's news has been blessed with severely higher quantities of EU-related coverage in recent years, the country basically hosts the EU in its capital Brussels, it delivered the first EU-president in 2009, and a reliable, longitudinal measurement of television news content is available.

Generally, not much evidence was found for the natural domestication factors related to the location of the EU institutions. Only a very limited part of EU-related coverage can be categorized as linked to the impact the EU has on local society. The other domestication element, the link to local actors, seemed more promising. The appointment of Belgian national Herman Van Rompuy as EU-president coincides with the start of a few years of significantly higher EU-coverage in Belgian television news. However, the thematic analysis indicated that this might be caused by the increased attention for the EU's role in (solving) the economic crisis, which would be a different perspective. To really find out whether the fact that the EU-president is Belgian has an effect on the coverage of the EU, we need comparative research, measuring topics and presence of the EU-president in the news in different countries on a sample of television news including the same days of broadcast. Evidently, it would also be helpful to be able to compare with the impact of another, non-Belgian EU president in the future. In Belgium, at least, the significant attention for the EU president indicates that the introduction of an EU-president can be called a success regarding media attention.

Does hosting Europe also lead to covering (more) Europe? Probably not. The tentative evidence of this chapter on the Belgian case does not provide convincing support for this statement. Moreover, the general share of EU-related news within 
the total coverage of Belgian television news is rather low. This can be seen as an indication that covering or not covering Europe is still largely an editorial decision which is only to a limited extent influenced by the proximity of the institutions. The physical advantage Belgian television news makers have by having their studios only five to ten kilometers from the location of the most prominent European leaders, actually raised higher expectations. The psychological advantage of Belgian newsmakers being better able (or even forced) to link European events to local society also does not live up to the expectations one might have from it. What remains are the classic forms of domestication, meaning links made by the newsmakers to try to create a proximity to the viewer, hoping that this will lead to increased interest, or at least to a news items viewers would not run away for. Using almost only Belgian members of the European Parliament as speaking news sources when the European Parliament is relevant, as was found in the study presented in this chapter, is one of those ways to domesticate Europe.

Ideally, Europe and the European institutions would not need domestication, since news about them is actually domestic news about one of the relevant policy levels of the viewers. While this may be stated like that from an institutional perspective, such thoughts are far from being a reflex in the heads of European citizens. EU-related news coverage may be one of the parts of news coverage most in need for elements which can appeal to the European audience. Because appealing to the European audience actually implies appealing to the different national audiences, the EU itself can do two things. First, introducing people who can serve as stable and visible leaders for the EU, like the EU-president, may help. Maybe future EU presidents may even be (partly) selected on their capacities to deal with the news media and abilities to attract positive attention to the EU. Second, several key positions in the EU may be even better distributed among nationals from all different countries, or at least some may be allocated to countries where attention (and support) for the EU is low.

Most of all, the tentative results from the present study deserve further and better research. A cross-national comparative approach is the next step to try to determine the use and impact of several forms of domestication in the context of EU-related news content. Only then, after making a thorough comparative account of domestication of EU-related news, the above mentioned conclusions can be set.

\section{References}

Chang, T. K., Shoemaker, P. J., Brendlinger, N. (1987), “Determinants of International News Coverage in the U.S. Media", Communication Research 14(4), 396-414.

Clausen, L. (2004), “Localizing the global: 'Domestication' Processes in international News Production", Media, Culture and Society 26(1), 25-44.

De Swert, K. (2009), Wordt Europa stiefmoederlijk behandeld? Presentation at Studienamiddag Europese Verkiezingen, Antwerp, Belgium. 
De Swert, K. (2011), Where is the balance in the news? The determinants of balanced coverage of political news sources in television news, Antwerpen: University of Antwerp.

De Swert, K., Wouters, R. (2011), “The coverage of China in Belgian television news. A case study on the impact of a foreign correspondent on news content", Chinese Journal of Communication 4(3), 331-347.

de Vreese, C. H. (2001), "'Europe' in the news. A cross-national comparative study of the news coverage of key EU events", European Union Politics 2(3), 283-307.

de Vreese, C. H., Banducci, S., Semetko, H. A., Boomgaarden, H. (2006), “The News coverage of the 2004 European Parliamentary election campaign in 25 countries", European Union Politics 7(4), 477-504.

de Vreese, C. H., \& Boomgaarden, H. (2006), “Media effects on public opinion about the enlargement of the European Union", JCMS 44(2), 419-36.

Galtung, J., Ruge, M. H. (1965), "The structure of foreign news: The presentation of the Congo, Cuba and Cyprus crises in four Norwegian newspapers", Journal of Peace Research 2(1), 64-91.

Gleisner, M., de Vreese, C. H. (2005), “News about the EU constitution. Journalistic challenges and media portrayal of the European Union Constitution", Journalism 6(2), 221-242.

Harcup, T., O'Neill, D. (2001), "What is news? Galtung and Ruge revisited", Journalism Studies 2(5), 261-280.

Riffe, D., Aust, C. F., Jones, T. C., Shoemaker, P., Sundar, S. (1994), “The shrinking foreign newshole of the New York Times", Newspaper Research Journal 15(3), 74-88.

Stępińska, A., Porath, W., Mujica, C., Xiao, X., Cohen, A. (2013), “The prevalence of news: Foreign, domestic and hybrid", in: A. Cohen (ed.), Foreign News on television. Where in the World is the Global village?, New York: Peter Lang, 21-40.

Uce, V., Schueremans, S., De Swert, K. (2006), “Dat was het Nieuws. Een analyse van de nieuwsvernieuwing van 2004", PSW papers, 1-32.

Wouters, R. (2009), “The nature of foreign news. Conceptual considerations about analyzing foreign news over time", in: A. Stępińska, News in Europe, Europe on news, Berlin: Logos Verlag, 43-62.

Wouters, R., De Smedt, J., De Swert, K. (2013), Inter-coder reliability in the Television News Archive. A report on coding issues, countries and actors in Belgian television news, Antwerp: Research group M2P (www.M2P.be).

Zaller, J. (2003), “A New Standard of News Quality: Burglar Alarms for the Monitorial Citizen”, Political Communication 20, 109-130. 


\section{Towards Cosmopolitan Europeans: Covering Europe for the Young Audience on Public Service Broadcasting in the Netherlands and United Kingdom}

\section{Introduction}

Communicating Europe to young audiences has been severely overlooked by academic communities in the past decades. It is thus very likely that this fact has only fuelled current low interest in European integration among young Europeans. The same holds true for the youth's disinterest in politics. The EU and politics are generally regarded both by the adults and the youth as unattractive, complicated and distant. It is argued that the EU lacks legitimacy (Meyer, 1999) or, as some coined it, suffers from a communication deficit (Follesdal \& Hix, 1993). In a broader sense, this separation between EU politics and public can be threatening for the democracy not only at EU level but also on the level of individual member states.

European children represent the future of the European Union and unless they become more cosmopolitan and acquainted with politics and the EU, Europe will continue to suffer from the lack of solidarity and low political interest which will hinder any further integration or even threaten the existence of the EU itself. Here, the media are undoubtedly an important player and especially public broadcasters should be bounded to fulfil their educational role. What picture of Europe do children get via children's news? Which topics are covered more frequently and which make it to the news only occasionally? And is Europe presented as a multicultural space?

Communicating Europe to a young audience has been out of the researchers' focus and same applies for the content and production of the children's news which albeit being an important actor of political socialization attracted only weak academic attention (but see Matthews, 2009; Buckingham, 2000; Lemish, 2007). Arguably socialization via children's news might take place only indirectly for such abstract topics like EU politics and Europe yet it might still have profound effects on later information acquisition, attitude formation and interests. Young people, however reluctant to watch programmes about politics, get the majority of information about politics from the TV (Russell, 2004).

This study thus assesses the content of the two prominent children's news programs in Europe and evaluates whether they offer balanced coverage of current affairs in terms of geographic focus and topics and thus might serve children's 
socialization within the European Union (see generally Conway et al., 1981; Van Deth et al., 2011). There are currently 13 children's news programs on air in 11 countries of the European Union. The reasoning for comparing the Netherlands and the United Kingdom is that they both broadcast children's news for over three decades and have comparable experience with reporting EU affairs.

\section{Importance of children's news}

Political socialization, often defined as a "developmental processes by which adolescents acquire cognitions, attitudes and behaviours relating to their political environment" (Atkin \& Gantz, 1978:184), firstly attracted researchers' attention in the mid-1960s. These "classical" studies of Greenstein and Hess and Torney (as cited in Atkin \& Gantz, 1978:184) argued that children acquire most of their political learning prior to the adolescent age. These early studies however barely mention the role of television or other media. To the contrary, research in the seventies made relatively strong claims about media. Atkin and Gantz (1978) state that a great amount of children regularly watch TV news which significantly contributes to their interest in, and knowledge about, political affairs.

Subsequent research in the eighties strictly divided the role of TV and of other media. TV news is often regarded as children's first contact with the world of politics (Atkin, 1981) and has an important role in the development of young people's political understanding. The most recent study suggests that the news usage, besides other influences, is an important antecedent of children's political orientation as it is positively related to children's political knowledge and issue awareness (Van Deth et al., 2011). Moreover, Simon and Merrill (1998) studied American children (on average 8-18-year-olds) and concluded that adequate provision of political information can enhance awareness of, and interest in, political and societal affairs.

Yet other research suggests that viewers understand and learn little from what they watch on TV (e.g. Gunter, 1987). Nevertheless, vast research conducted by Walma van der Molen (e.g. Van der Molen \& Van der Voort, 2000; Van der Molen, 1998) challenged these findings by concluding that, unlike adults, children were found to remember more news from TV watching than from reading. The reason, she argues, is the high congruence of verbal and visual parts in children's news compared to the adult news. This empowers the role of broadcasters, especially those of public service, as they have the primary duty to provide educational content.

The key question is whether already young children are capable of grasping political concepts, or in this case, EU issues. This has been a focal point of early childhood socialization research. While early studies recognized that small children acquire political experiences mainly in family context (cf. Easton \& Dennis, 1969), in the 1970s scientists concluded that political concepts are simply too complicated for younger children (e.g. Niemi \& Hepburn, 1995). Cullingford (as cited in Buckingham, 1999:250) defended the initial findings by claiming that children develop 
'political' concepts at a rather early stage, mainly through their daily experiences of institutions such as the school and the family. Taking the latest studies into account, Götzmann argues that primary school pupils comprehend basic political concepts (as cited in Van Deth et al., 2011:150). Similarly, Van Deth et al. (2011) concluded that already children in the first year of elementary school (on average 6-year-olds) exhibit consistent, structured political orientations.

Despite the acknowledgement that TV is an important tool for children's political socialization, content of the children's news has been largely neglected by the academic community. So far, most studies about children's news were single country studies (Matthews, 2009; Beelen, 2004; Beune, 2003) or two-country-studies (Buckingham, 2000) and the available research regarding the content of children's news is mainly single-topic focussed (War in Iraq: Lemish, 2007; Strohmaier 2007; Events of 9/11 in US: Van der Molen \& Vries, 2003). This study is pioneering in assessing the content of the children's news as a whole with special focus on European and EU politics news.

The production of the children's news has certain specificities. Buckingham (2010:131) argues that children's news has to provide more background in order to contextualize the foreground, has to combine entertainment with information in order to educate (which he coined as "edu-tainment") and is generally based on the journalists' assumptions about children's interests, knowledge and cognitive abilities. The expectations are that European and EU coverage differs between children's news in Britain and in the Netherlands, and that it largely depends on the attitudes and professionalism of journalists who produce the news, especially if some children's news editors openly consider politics as "a pretty dull business" (Russell, 2004:347).

Therefore the first research question states:

RQ1: What do journalists think and how do they feel about Europe and EU? To what extent do they embrace journalistic professionalism when covering EU for a young audience?

The EU is generally poorly visible in adult news (e.g. de Vreese, Banducci, Semetko, \& Boomgaarden, 2006; Peter \& de Vreese, 2004; Schuck et al., 2011a; Machill et al., 2006) and attracts media attention mainly during key events (Gleissner \& de Vreese, 2005). It is likely that these trends are even more pronounced in the children's news. Undoubtedly, the news coverage about Europe matters, as it can influence knowledge, attitudes, and support for EU and its policies (Schuck et al., 2011b). More precisely, it is the visibility of the EU and Europe which affects the public support for European integration (e.g. Maier \& Rittberger, 2008; de Vreese \& Boomgaarden, 2006) as well as general EU support (Vliegenthart et al., 2008). Despite the visibility not being a guarantee of public support, it can lead to knowledge gains about EU (de Vreese \& Boomgaarden, 2006a). Several studies have already shown that people rely on media when forming their opinion about EU (e.g. de Vreese \& Boomgaarden, 2006; Maier \& Rittberger, 2008) or about remote and abstract topics (i.e. agenda-setting role of media). Assuming that children and young viewers gener- 
ally lack the personal experience with Europe, in its geographical or political sense, it could be argued that the same principle applies. The second research question states. RQ2: How much news about Europe and EU is there in the children's news?

Besides the visibility, the frames and tone of the EU coverage have been at the centre of the research (e.g. Schuck et al., 2011a; de Vreese, 2003). Schuck et al. (2011a) concluded that general EU evaluations remain slightly negative but media coverage is overall positive towards the EU. Furthermore, they identify two important elements: EU is positively evaluated with regard to utilitarian benefit considerations and negatively evaluated with regard to the democratic nature and functioning of the EU. Building on these conclusions, this study focuses also on tone and frame of EU political news and the visualizing elements used in this coverage. The subsequent research question states.

RQ3: How is EU presented in the youth news? How is this done considering topics' selection, frame, tone of actors, multicultural portrayal and visual presentation?

Finally, to put these finding into perspective, another research question was developed.

RQ4: Are these findings very different from findings about the real television news?

\section{Methods}

This study applied quantitative research strategy, using methods of content analysis and interviews. A one day observation in the newsroom of the respective media outlets was conducted by the author as a supplement. Using comparative design, two children's news programs were selected for the analysis.

Newsround is a flagship of CBBC, Children's channel of BBC. Starting in 1972 under the title 'John Craven's Newsround' this programme has been pioneering in providing special news bulletins for children and it has been labelled as the first children's news ever. Newsround is also the oldest children's program on air in $\mathrm{BBC}$, targeting children from six to twelve years old and nowadays reaching daily around 800,000 children viewers (BBC, 2011). Daily, eight editions are broadcasted ranging from one to ten minutes, with two main editions at 07:40 and 17:00 hours. Editions are not meant to be broadcasted in schools. Newsround's crew consists nowadays of 35-40 people.

Jeugdjournaal is a similar programme within the Dutch public service broadcaster (NOS) presenting important domestic and international news in understandable form for the young audience (eight - fourteen years old). Jeugdjournaal has been on air since 1981 and its format has been copied to around thirty countries around the world. Aired daily in two different bulletins, broadcasted live at 08:45 and 18:45, it lasts five and ten minutes respectively ("Over het Jeugdjournaal," 2012). While the morning edition is meant to be streamed in schools followed by short discussion about topics, the evening bulletin targets the individual viewers. Jeugdjournaal's crew consists nowadays of approximately 25 people. 
Independent variables are the countries (United Kingdom, the Netherlands) and dependent variables are all variables as listed here below (available upon request in more details). This study contained two sub-projects. Firstly, media content analysis assessed the coverage of European countries and EU politics. For this, the main bulletins of Newsround (17:00, BBC) and Jeugdjournaal (18:45, NOS) were taken. Using systematic sampling, sixty-eight bulletins over the period from June 2009 to February 2012 were coded. On top of that twelve days of special EU events were selected and coded (e.g. European Parliament elections, EU summit or signing of Fiscal Compact Treaty). Overall, 21.5 hours of broadcasting was coded. Research units were the individual news stories.

The coding was proceeded in three consecutive steps. Firstly, all news items were coded for three variables: Time, General topic and Content focus of the story (Part I.). Secondly, selected news was coded for Topic of news item, Talking of Youth, Multiculturality and Visual representation (Part II.). Lastly, all items dealing with EU topics were coded for additional variables (Part III.): EU specific topic, Frames of item, EU Actors, Tone of EU actors. For the news item to be coded as an EU topic, it had to at least once mention or show one or more EU actors, institutions or symbols. References to European leaders and European ministers were also regarded as EU topics.

In total 160 news bulletins which contained 999 news items were coded. Krippendorff's Alpha was calculated for the inter-coder reliability for variables in section I. and II. The figures ranged from .73 to 1 . Due to the rare occurrence of variables in the third section of coding (for the items about EU), it was not possible to proceed with the standard procedure of the inter-coder reliability test. Therefore, the variables in the third section were coded in the presence of an additional coder for all items of the sample $(\mathrm{N}=11)$.

The second subproject used questionnaires to evaluate journalists' personal characteristics, professionalism and EU attitudes. The content and form of the questionnaire was inspired by Eurobarometer survey and the special edition of Eurobarometer New Europeans (Eurobarometer, 2010).

To maintain the comparative model of this study, journalists of British children's news Newsround and of Dutch children's news Jeugdjournaal were selected as research units. Eventually, six completed questionnaires were obtained per news outlet concluding a total of twelve, with identical gender ratio (i.e. four women and two men).

\section{Profile of children's news journalist}

Journalistic education seems to be more crucial in Dutch children's news where five out of six journalists possess the diploma. To the contrary, only half of the BBC sample has followed higher journalistic education. Dutch journalists are clearly more multilingual and seemingly, they have more experiences from foreign countries. Regarding EU and cosmopolitan attitudes, British journalists appear to be slightly less 
attached to the EU compared to their Dutch counterparts who are also somewhat more proud to be EU citizens.

When asked for their personal attitudes, the EU apparently means different things for Dutch and British journalists. Despite sharing answers like free travelling, different cultures, history and beauty of the continent, for Dutch journalists the EU is also about transparency, coherence, Euro currency and European laws. One Dutch journalist also stressed the "cooperation among countries to work together for trade, peace and politics" and "to help each other", however his British counterparts were a lot more cynical stating that "'one policy for all' does not work" or even stronger, that EU "gives me nothing but dictates the way my country is run without any benefit to us, e.g. immigration, farming, economy." Cynicism among Dutch journalists is less pronounced stating the "worries about weak economies."

Country membership in the EU is significantly more positively evaluated in the Netherlands. The reason as stated by journalists is the fact that the Netherlands is a small country and as one journalist wrote "cooperation makes us stronger" and "borders are so 20th century." British journalists are comparatively more sceptical about UK's membership in EU. Generally they state that EU is good for their country when it comes to trade and economic union but it is rather disadvantageous when it comes to bailing out weak states or adhering to unified EU laws.

British journalists also think that the current state of European integration is more than enough. To the contrary, according to Dutch journalists it should be unified even further. The most significant differences among Dutch and British children's news journalists are in their attitudes towards covering EU for the young audience. British journalists are clearly less attracted by EU news and even consider it boring, dry, difficult for adults and not relevant for children. They also believe that children are "removed from EU politics because they do not pay taxes." According to Brits, the EU is simply "too high level" and it is "hard to engage kids" for this topic. In apparent contrast to this, two Dutch journalists perceive EU as an important topic; "let it be the Euro or Eurovision." They like the topic even more if they can give a practical example. Only two Dutch journalists did not like the EU as a topic, because it is boring, too political and has little effect on children.

Another significant disagreement among Dutch and British journalists is whether the EU is difficult for children to understand. While British journalists strongly felt that EU is too complex, irrelevant, too difficult to understand, and it makes no sense to report it unless it affects children personally, the Dutch journalists adopted a totally different approach. They largely agreed on the fact that EU is not difficult for their audience and stated that it is only up to them to make EU understandable and attractive. EU can be explained simply, according to Dutch journalists, although it is not always an easy task but as one journalist said "it depends on the details you pick up and you leave." Only one Dutch journalist thought that EU is boring for children but not difficult.

Lastly, journalists from two children's news programs did not agree whether EU news is relevant for their audience or not. While only two of six British journalists 
agreed that EU is relevant for children because all is interconnected in today's world and because children might go on holidays to other countries, four out of six Dutch journalists stated that EU is relevant mainly for children's futures, because decisions are being made about them and also to balance the influence of USA. Neutral opinion from one Brit claimed that it all depends on the EU policy in question education being of particular relevance for children also on EU level. Only one Dutch journalist thought the EU is not relevant for children's daily life, compared to three British journalists who claimed that children might understand the geographical meaning of Europe but do not care about its political side. In terms of usage of the visual elements (maps, graphics, tables, graphs etc.) journalists in both countries agree that these items help to explain complex issues.

To sum it up, there is a significant disagreement between Brits and Dutch about the EU coverage for children. While Dutch journalists are more likely to show an effort to cover EU topics however challenging they might be in terms of explanation, British journalists perceive the EU as purely irrelevant for children unless it affects them directly and thus they refrain from covering it.

\section{Europe and EU in the news}

The amount of domestic news appeared to be identical for both media and represents more than a half of coverage. The difference emerges for news about European and non-European countries (Table 1). While in both news outlets, the non-European counties predominate over the European, the variance is smaller in Dutch children's news. The difference between Jeugdjournaal and Newsround is statistically significant both for the coverage of European countries $(U=114.357$, $P=0.002)$ and for coverage of non-European countries $(U=114.457, P=.013)$.

Table 1

Content focus of the news items

\begin{tabular}{|l|c|c|}
\hline \multicolumn{1}{|c|}{ Type of the news } & $\begin{array}{c}\text { Newsround } \\
(\mathbf{N}=\mathbf{5 3 8 )}\end{array}$ & $\begin{array}{c}\text { Jeugdjournaal } \\
\text { (N = 461) }\end{array}$ \\
\hline Domestic $(\mathrm{N}=636)$ & 64 & 63 \\
\hline European $(\mathrm{N}=203)$ & 17 & 25 \\
\hline Non-European $(\mathrm{N}=399)$ & 44 & 36 \\
\hline Domestic and European & 9 & 9 \\
\hline Domestic and Non-European & 14 & 11 \\
\hline
\end{tabular}

Note. In percent. $\mathrm{N}=999$.

Overall, one fifth of the sample represented news in which European countries appeared. In addition to that only one percent of all news was about European Un- 
ion (despite the large definition for coding). Dutch children's news featured the EU news substantially more often $(\mathrm{N}=8)$ compared to their British counterparts $(\mathrm{N}=3)$.

To answer the second research question, there is news about Europe in children's news however it is far from being an excessive coverage. Despite the geographical proximity, European countries appear in the news less often than non-European countries. Nevertheless, out of these two outlets, Dutch children's news seems to be more Europeanized. European Union, however, remains almost invisible in children's news. Scarce coverage of EU affairs is common for both outlets yet comparatively there is more EU news on Dutch children's news than on Newsround.

\section{Presentation of Europe}

The data show that Dutch news portray Europe more in hard news style while British Newsround covers it more in soft news style (Table 2). Dutch European news is about politics, society \& culture or crime \& accident considerably more than European news in Britain. In United Kingdom, the European topics are noticeably more often about sport and rarity. Lastly, it is evident, that British broadcaster put more emphasis on youth-related topics which are not that frequent in Dutch Jeugdjournaal. Interestingly enough, political news in Dutch children's news outweighs the youth related issues. Out of all these categories, the difference between Jeugdjournaal and Newsround is statistically significant for crime \& accident $(U=4481$, $P=0.043)$ and sport $(U=4278 ; P=0.010)$.

Table 2

Topics of the news

\begin{tabular}{||l|c|c||}
\hline \multicolumn{1}{|c|}{ Topic } & Newsround & Jeugdjournaal \\
\hline Politics \& Economy $(\mathrm{N}=28)$ & 10 & 17 \\
\hline Crime and Accident $(\mathrm{N}=45)$ & 16 & 27 \\
\hline Nature $(\mathrm{N}=46)$ & 20 & 25 \\
\hline Culture and Society $(\mathrm{N}=51)$ & 19 & 30 \\
\hline Rarity $(\mathrm{N}=50)$ & 30 & 20 \\
\hline Sport $(\mathrm{N}=52)$ & 34 & 19 \\
\hline Youth related $(\mathrm{N}=20)$ & 13 & 7 \\
\hline Other $(\mathrm{N}=13)$ & 10 & 7 \\
\hline EU politics $(\mathrm{N}=11)$ & 3 & 7 \\
\hline
\end{tabular}

Note. In percent. $\mathrm{N}=203$. One item could contain more than one topic, maximum of three.

While Newsround appears to cover almost twice as much of youth-related European issues, it does not give the voice to its audience. There is a statistically sig- 
nificant difference between Jeugdjournaal and Newsround in presenting young interviewees in the news $(U=4401, P=0.017)$. It is the Dutch news which shows young interviewees in 26 percent of its European coverage compared to only 12 percent in Britain. This is crucial because same-age peers from other countries appearing on TV might help to make the connections with other cultures.

Regarding the level of multiculturality, whether the news represents Europe and its countries as a multicultural environment, the data showed that the majority of the news about Europe in both countries demonstrated no multiculturality whatsoever. Yet there is some indication about weak multiculturality in both news outlets.

What is surprising though is the usage of European map in European news. Despite being an important tool for explaining complex issues, the usage of a graphic map seems to be a strong asset only of Dutch Jeugdjournaal (Table 3). The difference between Newsround and Jeugdjournaal is statistically significant $(U=2081, P=0.000)$. British children can only guess where the country lies and how far from them it is because 96 percent of the European news does not contain any map. Maps on BBC Newsround were however present in non-European news but these items were not coded for this variable therefore any data is available.

Table 3

Presence of a map in European news

\begin{tabular}{||l|c|c|}
\hline \multicolumn{1}{|c|}{ Type of map } & Newsround & Jeugdjournaal \\
\hline Domestic and foreign country $(\mathrm{N}=29)$ & 3 & 23 \\
\hline Only foreign country $(\mathrm{N}=3)$ & 1 & 2 \\
\hline No map included $(\mathrm{N}=171)$ & 96 & 75 \\
\hline
\end{tabular}

Note. In percent. $\mathrm{N}=203$.

Analyzing news about EU affairs in more details, these represented only one percent of the whole, and five percent of the European sample. Contrary to the expectations, Newsround covered only one topic of 12 selected EU events of special importance. The Dutch Jeugdjournaal covered five of them. This corresponds with opinions of Dutch journalists who deem EU politics relevant for children. Furthermore, it seems that the level of importance of the EU event is not the news criteria for covering EU on BBC Newsround. This corroborates with earlier results, since the British journalists expressed that the main criteria for them to cover the EU is the direct effect on children or whether it concerns a news which is been largely talked about in the society.

Similarly, contrary to the expectations but in line with journalists' reasoning, during the period of regular coverage Newsround featured two of its three items and Jeugdjournaal three of its eight items. This suggests that while Jeugdjournaal seems to follow the mainstream news flow about EU and then adapts it for a children's audience, Newsround behaves against this convention and rather looks for topics itself. Due to the very low number of EU news items $(\mathrm{N}=11)$, no statistical 
analysis can be performed. Instead, a list of all EU topics which appeared in the news (Table 4) is provided.

Table 4

Specific topics of European Union news

\begin{tabular}{|c|c|c|l||}
\hline \hline Outlet & Date & Time & \multicolumn{1}{|c|}{ Topic } \\
\hline $\mathrm{N}$ & 8.11 .11 & $115 \mathrm{~s}$ & Greece: money problems. \\
\hline $\mathrm{N}$ & 5.6 .09 & $140 \mathrm{~s}$ & Brown's party in troubles, to lose in EP elections. \\
\hline $\mathrm{N}$ & 11.7 .11 & $120 \mathrm{~s}$ & Common Fisheries policy about to change in Europe. \\
\hline $\mathrm{J}$ & 18.9 .09 & $25 \mathrm{~s}$ & Farmers' protests against low milk prices in EU. \\
\hline $\mathrm{J}$ & 25.11 .09 & $30 \mathrm{~s}$ & Van Rompuy as a president of EU, new PM in Belgium. \\
\hline $\mathrm{J}$ & 10.6 .11 & $35 \mathrm{~s}$ & Croatia to join EU in 2013, all conditions accomplished. \\
\hline $\mathrm{J}$ & 2.3 .12 & $165 \mathrm{~s}$ & Situation in Syria: what to do with Assad? \\
\hline $\mathrm{J}$ & 5.6 .09 & $160 \mathrm{~s}$ & 2009 EP Elections; Wilders won 4 seats in EP - success. \\
\hline $\mathrm{J}$ & 26.3 .10 & $100 \mathrm{~s}$ & “Will EU help Greece?” summit. Yes, under conditions. \\
\hline $\mathrm{J}$ & 26.10 .11 & $185 \mathrm{~s}$ & Eurocrisis, what to do with Greece? Eurozone summit. \\
\hline $\mathrm{J}$ & 27.10 .11 & $100 \mathrm{~s}$ & Closing the summit about how to help Greece. \\
\hline
\end{tabular}

To summarize the EU news on British Newsround, these items were relatively long yet they featured EU rather marginally without further explanation and the EU was mentioned fairly indirectly. Consequently, very few graphic elements were used and only one map (of Greece, not Europe) featured in the items.

To summarize the EU news on Dutch Jeugdjournaal, these items were longer and featured EU prominently. The role of EU was generally well explained. Coverage of a large part of the important EU events on Jeugdjournaal was done very originally and it was obvious that an effort had been made in order to make the topic understandable. Contrary to Newsround, Jeugdjournaal largely used special visual elements, including the map of EU member states or a map of countries with Euro currency.

To conclude, four out of eleven EU items were about Greece and related financial problems in Euro countries. This issue has been featured a lot in the news during the past three years and children's news could not neglect it. However, British children's news did not cover any of the EU summits where Greece was discussed, contrary to Jeugdjournaal. While Newsround sent the journalist to Greece to make the story relevant for their audience, Jeugdjournaal used various creative ways in the coverage (Monopoly, graphics, cartoons of leaders etc.). Secondly, agricultural policy represented two of eleven EU items. This corresponds with the fact that if the EU topic covers an area which could be linked to children's daily life such as eating fish or drinking milk, this news is more likely to be picked up by children's news editors. Consequently, two items of eleven mentioned the EP elections, yet in both countries this topic was covered within a strong national angle. Topics of Enlarge- 
ment, Common foreign policy and the appointment of EU officials were absent in British news which again corresponds with the views of British journalists about the irrelevancy of the political side of Europe for their audience.

\section{Adult vs. children's news}

The adult news considerably differs from children's news in space which is devoted to political information. While political topics are predominant in adult news, accounting for almost half of the coverage (Heinderyckx, 1993), they are generally marginal in children's news. Secondly, the most noticeable difference between adults' and children's news is the amount of EU coverage. The European Union was present in only one percent of the children's news coverage while in adult news the EU is generally more salient, accounting for less than ten percent of political coverage in routine periods (Peter \& de Vreese, 2004) up to around twenty percent of the whole coverage in EU events (Schuck et al., 2011b). In the later case, the amount of EU items on adult's news on BBC and NOS was almost identical, which is not the case for British and Dutch children's news.

Comparing the EU specific topics of children's news and of adult news, there is a correspondence in covering EU economy, Euro currency and economic policies the most frequently (Schuck et al., 2011b). However, further EU topics of adult news, such as enlargement or political system remained almost absent in children's news.

\section{Conclusions \& discussion}

The comparison of content and journalists of children's news in two European countries gives an interesting insight in the news production for a young audience. The expectations that European and EU coverage depends mainly on the personal attitudes and professionalism of journalists seem to be correct. Britain is traditionally seen as Eurosceptic while the Netherlands is usually termed as pro-European and the overall results correspond with these tendencies. Dutch journalists considered EU more relevant for their audience and there was consequently more EU news on Dutch Jeugdjournaal, compared to BBC Newsround.

The aim of this study was to find out what picture of Europe and European Union children receive through their news. Political socialization research states that children experience the first contact with politics through TV news. Public service broadcasters, from their role of information providers and educators, should supply this. However, as this study shows, British coverage of European countries provides significantly more soft news while Jeugdjournaal provides rather hard news, including seventeen percent of politics, compared to ten percent in Britain.

It seems that British children's news tries to present an uncomplicated peaceful world by minimizing violence and crime related stories. This was also confirmed 
during the observation in the newsroom of Newsround which followed the incident of a shooting in a French Jewish school. ${ }^{1}$ Despite being breaking news it was not, according to the personnel, covered on the day when it happened. In the following days, the coverage was rather brief and mainly reassuring children that this had been an uncommon event. Overall, the findings point to the fact that children's news bulletins are likely to follow different news values than adult news (Harcup \& O'Neill, 2010). Yet these values might not be identical for all children's news.

The European Union and its political side appeared to be almost invisible in children's news. This is not surprising considering the fact that EU is not an attractive topic for adult news either. Yet this finding is alarming because it tells us that children's news does not in any way help to decrease communication deficit. Europe and its politics will remain distant, boring or complicated because how can we expect a knowledgeable and participative European public if we do not provide them with the information so they can, as they grow older, make an opinion about it? Or is EU really too difficult for children? According to early political socialization research children are capable of understanding political concepts and Dutch journalists largely agree with these findings. Yet it is still questionable whether socialization actually takes place at this young age for such an abstract topic as the European Union and whether simple information provision can serve it.

It is true that Newsround targets slightly younger audience but this does not explain why a ten-year-old Dutch can understand EU and make a statement about the bailout fund for Greece while a ten-year-old Brit cannot. Well, the British is not even asked. Clearly, there is a problem which lies mainly in the function and concept of the children's news. The everlasting conundrum of whether public service broadcasters should provide what the audience has to know or what it interested in is even more crucial for production of children's news. I would argue that considering the fact that children's news is a means of political socialization, besides of course other factors, it should not be blindly following the dogma of what the audience wants, especially when it concerns public service broadcasting. Naturally, if covering "boring" politics makes the audience go away, the effect on political socialization is again zero. The challenge lies in making the political and EU topics interesting so that they communicate the message in an accessible, clear and simple way which will attract and inform the young audience; a reporting style coined by D. Buckingham as "edu-tainment". This is not an easy task, quite the opposite. It requires time, creativity and will.

The amount of EU and political coverage on both children's news is not satisfactory. Nevertheless there is one difference. Journalists at Jeugdjournaal seem to have at least good intentions and show some will to put more EU in the coverage. During my observation in the newsroom, a journalist and editor were discussing why the story about the newly elected French president was important. They agreed that it

1 On 19 $9^{\text {th }}$ March 2012 three children and a teacher were shot dead by a gunman at a Jewish school in the French city of Toulouse. More information: http://www.bbc.co.uk/news/ world-us-canada-17426313. 
was because of the EU where François Hollande replaced Nicolas Sarkozy in tandem with Angela Merkel. Eventually, this comment was not part of the news item due to time restrictions. The journalist concluded that she would have to explain why the Franco-German tandem is important.

In Britain, however, no such intentions were perceived and from informal talks with journalists I got the impression that nothing is more boring than EU. Answers from the questionnaires proved my impression to be right. The data from content analysis and journalists corroborates. The topic of agricultural EU policy was referred to through traditional fish \& chips and Greek financial problems were explained by the familiar face of journalist Lea who travelled to Greece. To the credit of Newsround crew, they also have creative ideas and can make difficult topics accessible for children. When journalist explained about taxes, in connection to the British state budget, a part of the report was shot in a candy shop and the journalist used the analogy of buying candy to demonstrate tax payment.

After mapping the situation and raising the points, let me now suggest some solutions. Firstly, slipping the EU more often into the coverage, possibly without further explanation, might help children to perceive the EU as something normal. After all, visibility already triggers some awareness. Secondly, there is enormous potential which lies in cooperation with the educational system. The morning edition of Jeugdjournaal is specifically made to be broadcast at schools followed by a short discussion about current news. Furthermore, Jeugdjournaal is also involved in producing School TV2 and since 2011 they have also produced small one-topic video stories (e.g. political crisis, elections) which are then supplemented with text and exercises ${ }^{3}$ and are distributed to around 3,000 Dutch schools subscribed to this service. Arguably, all this might explain why Dutch journalists think that their audience understands the EU while British journalists think the opposite. Yet all these examples should be an inspiration for BBC as it is a commitment for NOS to continue covering political topics and increase the EU coverage in order to fulfil the educational role and in theory serve the children's political socialization.

Besides, isn't the quantity of eight news bulletins of Newsround per day to the detriment of the quality? If less time is spent on quantity, more time could be devoted to cover difficult topics in interesting ways. If the change comes gradually, it is likely to be accepted by the audience. This way, BBC could help the political socialization by making politics and EU just as normal as anything else.

Undoubtedly, children's news, their journalists and the audience requires more investigation. Cross-national research might help to find out a suitable concept of this news format and comparative study could provide insights into its news values. Furthermore, the bulletins should be assessed for their level of infotainment and edu-tainment. New interactive ways to engage children through media should also be tested as well as children's knowledge and attitudes towards politics and EU which are of societal significance. Current situation is not comply-

2 Weekly, 30 minutes long bulletin about current affairs intended to be used in schools.

3 Produced by CED-group Rotterdam. 
ing and the challenge lies right here. Thus unless we want to bring up more and more generations whose interest in politics and Europe will be declining, change is inevitable.

\section{References}

Atkin, C. (1981), "Communication and political socialization”, in: D. Nimmo, K. Sanders (eds), Handbook of Political Communication, Beverly Hills, CA: Sage, 299-328.

Atkin, C., Gantz, W. (1978), "Television News and Political Socialization", Public Opinion Quarterly 42(2), 183-194.

BBC (2011, Nov 23), Newsround to receive Bafta honour, Retrieved Jan 15, 2012, from BBC News: Entertainment \& arts: http:/ / www.bbc.co.uk/news/entertainment-arts-15856751.

Beelen, R. (2004), 'Die meneer heeft er verstand van!': een beschrijvend onderzoek naar de manier waarop kinderen omgaan met nieuwsbronnen in het Jeugdjournaal (Unpublished doctoral dissertation), Faculteit der Maatschappij- en Gedragswetenschappen, Opleiding Communicatiewetenschap, Amsteram.

Beune, J. (2003), Een betrokken blik: onderzoek naar emotionele reacties en informatieverwerking bij het kijken naar het Jeugdjournaal (Unpublished doctoral dissertation), Faculteit der Maatschappij- en Gedragswetenschappen, Opleiding Communicatiewetenschap, Amsterdam.

Buckingham, D. (2000), The Making of Citizens: Young People, News and Politics, London: Routledge.

Buckingham, D. (2010), “The Making of Citizens: pedagogy and address in children's television news", Journal of Educational Media 23(2-3), 119-139.

Buckingham, D. (1999), "Turning on the news", Journal of Adolescent \& Adult Literacy 43(3), 250-253.

Convey, M. M., Wycloff, M. L., Feldbaum, E., Ahern, D. (1981), “The News Media in Children's Political Socialization", Public Opinion Quarterly 45, 164-178.

de Vreese, C. H. (2003), Framing Europe: television news and European integration, Amsterdam: Aksant.

de Vreese, C. H., Banducci, S., Semetko, H. A., Boomgaarden, H. G. (2006), “The news coverage of the 2004 European Parliamentary Election campaign in 25 countries", European Union Politics 7(4), 477-504.

de Vreese, C. H., Boomgaarden, H. G. (2006), "Media effects on public opinion about enlargement of the European Union", Journal of Common Market Studies 44(2), 419-436.

de Vreese, C. H., Boomgaarden, H. J. (2006a), “News, Political Knowledge and Participation: The Differential Effects of News Media Exposure on Political Knowledge and Participation", Acta Politica 41, 317-341.

Easton, D., Dennis, J. (1969), Children in the political system. Origins of political legitimacy, New York: Mc Graw-Hill.

Eurobarometer (2010), Public Opinion in the European Union, Eurobarometer nos. 73.3. New Europeans, Brussels: European Commission, retrieved from: http://ec.europa.eu/ public_opinion/archives/ebs/ebs_346_en.pdf. 
Gleissner, M., de Vreese, C. H. (2005), “News about the EU Constitution. Journalistic challenges and media portrayal of the European Union Constitution", Journalism 6(2), 221-242.

Follesdal, A., Hix, S. (2004), “Why There is a Democratic Deficit in the EU: A Response to Majone and Moravcsik", Journal of Common Market Studies 44(3), 533-562.

Gunter, B. (1987), Poor Reception: misunderstanding and forgetting broadcast news, Hillsdale: Erlbaum.

Harcup, T., O'Neill, D. (2001), “What Is News? Galtung and Ruge revisited”, Journalism Studies 2(2), 261-280.

Heinderyckx, F. (1993), “Television News Programmes in Western Europe: A Comparative Study", European Journal of Communication 8(4), 425-50.

Jeugdjournaal (2012), Over het Jeugdjournaal, Retrieved January 15, 2012, from NOS Jeugdjournaal: http://jeugdjournaal.nl/over/het-jeugdjournaal/.

Lemish, D. (2007), “Israeli children's TV going to war with Iraq”, in: D. Lemish, M. Götz (eds), Children and media in times of war and conflict, Cresskill, NJ: Hampton Press, 201-213.

Machill, M., Beiler, M., Fischer, C. (2006), “Europe-topics in Europe's media: the debate about the European public sphere: a meta-analysis of media content analyses", European Journal of Communication 21(1), 57-88.

Maier, J., Rittberger, B. (2008), “Shifting Europe's Boundaries: Mass Media, Public Opinion and the Enlargement of the EU", European Union Politics 9(2), 243-267.

Matthews, J. (2009), “Negotiating News Childhoods: News producers, visualised audiences and the production of the children's news agenda", Journal of Children and Media 3(1), 2-18.

Meyer, C. (1999), “Political Legitimacy and the Invisibility of Politics: Exploring the European Union's Communication Deficit", Journal of Common Market Studies 37, 617-639.

Niemi, R. G., Hepburn, M. A. (1995), “The rebirth of political socialization”, Perspectives on Political Science 24, 7-17.

Peter, J. \& De Vreese, C. H. (2004), “In Search of Europe: A Cross-National Comparative Study of the European Union in National Television News", The Harvard International Journal of Press/Politics 9(3), 3-24.

Russell, A. (2004), “The truth about youth? Media portrayals of young people and politics in Britain", Journal of Public Affairs 4(4), 347-354.

Schuck, A. R., Azrout, R., Boomgaarden, H., Elenbaas, M., Van Spanje, J., Vliegenthart, R., et al. (2011a), Media visibility and framing of the European Parliamentary Elections 2009: A media content analysis in 27 countries, unpublished manuscript, 1-35.

Schuck, A. R., Xezonakis, G., Elenbaas, M., Banducci, S. A., de Vreese, C. H. (2011b), “Party contestation and Europe on the news agenda: The 2009 European Parliamentary Elections", Electoral Studies 30, 41-52.

Simon, J. Merrill, B. D. (1998), "Political socialization in the classroom revisited: The kids voting program", Social Science Journal 35, 29-43.

Strohmaier, P. (2007), "How TV producers dealt with the war in Iraq in children's programs”, in: D. Lemish, M. Götz (eds), Children and media in times of war and conflict, Cresskill, NJ: Hampton Press, 121-142.

Van Der Molen, J. H. W., De Vries, M. (2003), “Violence and consolation: September $11^{\text {th }} 2001$ covered by the Dutch children's news", Journal of Educational Media 28(1), 5-17. 
Van Der Molen, J. H. W. (1998), “Children's and adults' recall of television versus print news: Is print really better?", Communications: The European Journal of Communication Research 23, 475-490.

Van Der Molen, J. H. W., Van der Voort, T. H. A. (2000), “The impact of television, print, and audio on children's recall of the news: A study of three alternative explanations for the dual-coding hypothesis", Human Communication Research 26, 3-26.

Van Deth, J., Abendschön, S., Vollmar, M. (2011), “Children and Politics: An Empirical Reassessment of Early Political Socialization", Political Psychology 32(1), 147-173.

Vliegenthart, R., Schuck, A. R., Boomgaarden, H. G., de Vreese, C. H. (2008), “News coverage and support for European integration 1990-2006", International Journal of Public Opinion Research 20(4), 415-439. 
Javier Ruiz Soler

Lund University, Sweden

\section{The Role of the Euroblogosphere in a Context of the European Public Sphere}

\section{Introduction}

The lack of a European public space where the citizens can share their thoughts and expressions about the decisions taken in European level correlates with the democratic deficit that the European Institutions have. Many commentators agree that democratic deficit is linked to the existence and function of EPS and the deliberative democracy it creates (Papanagnou, 2013). According to a pan-European online newspaper, "the Euroblogosphere represents a large number of European citizens who criticize the democratic deficit in European institutions, or more simply those who want to share criticisms, suggestions or gossip in an online community" (Sforza, 2012).

The argument of this article is that the Euroblogosphere seems to be one path that holds out much potential in this regard, given that it comprises many independent bloggers writing their personal opinions on EU matters, usually in more than one language (Ruiz Soler, 2012). At the same time, the Euroblogosphere could be a central bridge between national and European discussions (Fossum \& Schlesinger, 2007). It might foster participation in European discussions, as it is easier to reach international audience without having to pass through and be filtered by national mass media that invariably angle the EU issues through the lens of national political cultures (Ruiz Soler, 2012).

At the moment, one of the main reasons of the democratic deficit of the EU is that there is no regular feedback flow from the citizens to the EU decision making centers (Michailiodou, 2009). The internet, due to its characteristics, that is cheap, global and two way communication (Papanagnou, 2013; Michailiodou, 2009) may be seen as one of the contributions to the development of a European Public Sphere (Michailiodou, 2009). The nature of the European Public Sphere can be described as interconnected national public spheres, multilingual community and geographical distance between members of the public (Michailiodou, 2009).

It seems that there is no full understanding of ways in which various groups and individuals engage in civil society and political processes in the development of supranational developments such as fostering of a more integrated Europe (Wessels, 2009). Hence, it is necessary to conduct empirical studies and theoretical exploration of the role of the online media. This paper aims in filling in a gap in academic research on a topic of the Euroblogosphere and to complement the existing literature 
about the European Public Sphere by focusing on relations between these two concepts. The main question of this paper will be: "What is the contribution of the Euroblogosphere into the European Public Sphere?"

\section{Literature overview}

There is not much literature about the specific topic of EU blogosphere and the role it has on society. Academically, two papers written by Feldhof (2009) and Ondarza (2007) have been published about the Euroblogosphere until 2009, when an aggregator of blogs about EU topics was created by independent citizens. The aggregator "bloggingportal.eu" contains today more than 1000 blogs written in different languages.

Feldhof (2009) concludes in his research that Euroblogosphere fails fostering political participation of the masses and that blogosphere has a limitation in a control of policy-makers. Ondarza (2007), on the other hand concludes that the Euroblogosphere is a partial public sphere, where European institutions are responsible to provide a basis for the growth of it. The Euroblogosphere can be understood as a virtual partial public sphere of people who are interested in European politics and social issues.

Recently, a new academic article was written by Papanagnou (2013). The paper presents the results of the empirical research conducted on the emerging EU-blogosphere and relates them to the Habermasian notion of the public sphere. Conceptually, it traces the development of the public sphere as a normative category and establishes a series of criteria that seem to guarantee its effective operation as a democratic bridge between publics and authorities in a transnational context. In the process, it refers to the various empirical works in this area which aim to trace the public sphere in Europe. The empirical part analyzes the findings of the qualitative research conducted with EU-bloggers (expert interviews and content analysis). The results show that the EU-blogosphere to some extent exhibits characteristics of an effective (if inconsistent) transnational public sphere (extension of democratic debate, promoting an EU-common identity, achieving at times influence). Papanagnou suggests that further systematic studies and explorations of the phenomenon of the Euroblogosphere are more than necessary to get a more balanced picture (Papanagnou, 2013:25).

The debate about the European Public Sphere (EPS) is more intense. One may recognize different perceptions of the EPS. For example, Maria Heller and Ágnes Rényi (2007) claim that all preconditions for a development of the EPS are set, but there are problems for its development that must be solved. In particular, there is still an open question regarding the way the EPS may be developed: by the Europeanization of national media, or by the creation of a transnational, pan-European media. Jos de Beus (2010) supports a concept of the Europeanization of national media, while Bruggmann (2009) points that a multitude of EU transnational media 
has evolved over the last 20 years and that they have a small, but significant and growing audience. Bruggmann (2009:694) even defines a typology of transnational media.

The common conclusion is that the existence of an arena for interaction between the nations is necessary (Van de Steeg, 2009). Without informed citizens and the possibility to participate, there is no interest in Europe and democracy. The democratic deficit of Europe can only be eliminated only if the EPS, in which a democratic process of participation is incorporated, will be developed (Papanagnou, 2013). In this regard, communication environments that historically provided platforms for a public debate are changing with the development of digital technologies and the World Wide Web (Wessels, 2009). The current emergence of an information society provides the context for the development of the $21^{\text {st }}$ century public sphere, including the EPS.

\section{Theoretical background}

\section{European Public Sphere}

Scholars have been studying the concept of the European Public Sphere (Koopmans \& Statham, 2010). They recognized some particular stumbling blocks, including national media, a variety of languages, and national cultures (Kaitatzi-Whitlock, 2007). However, it is worth mentioning that there are simultaneous public debates on the European issues on a national level. This means that information required for a participation in a public debate on the EU issues is available to the majority of the Europeans through conventional media. Consequently, an all-inclusive, democratic European public sphere may, potentially, emerge (Michailiodou, 2009).

John Erik Fossum and Philip Schlesinger (2007) established two models of the EPS development: the regulatory model and the federal model. Both of them are political models for the EU with different characteristics and different concepts of public sphere. First model defines the EU as a "regulatory entity engaged in problem-solving." The purpose of the EU is ultimately a "network governance," where members should use the institutions as platforms for discussion and for seeking the problems' solutions. The second model, the federal EU, is opposite to the first one. Based on the EU as a democratic constitutional state, it assumes a need for the European identity developed by "a public opinion mobilized to influence." This model aims for the Europeanization and transnationalization of national spheres, taking into consideration "a respect of democracy, difference, pluralism, human rights and vulnerable identities." Interestingly, none of these two models contemplate the use of the internet.

Maria Heller and Ágnes Rényi (2007) claim that the EPS might be close to the first model, the regulatory one. However, due to the development of the online me- 
dia and the Internet access, it may change. The increase of interaction may lead to more active participation of the citizens in the EPS.

\section{Blogging}

Blogosphere is a platform for citizens to express their ideas and share their comments with other bloggers without any restrictions. Bloggers do not only produce content to post on their blogs, but also build social relations with their readers and other bloggers. Discussions "in the blogosphere" are occasionally used by the media as a gauge of public opinion on various issues. Because new, untapped communities of bloggers and their readers can emerge in the space of a few years, the Internet marketers pay close attention to "trends in the blogosphere" (Bahnisch, 2006).

A political blog, that is a central object of this study, is a form of the Internet blog covering politics. There are differing views as to whether political blogs constitute political participation. One view is that political blogs are used as a public forum for discussing the community, candidates, policy, and voting processes. Another view is that political blogs are not about political participation, but are online 'soapboxes' for people's political expression.

It is worth mentioning that there is a relation between reading political blogs and voting, support for political candidates, and attempts to persuade others to vote in some a particular way. The readers of political blogs may also interact with the authors through a comment section or social media (Bahnisch, 2006).

\section{Model for the research: semi-structured online interviews}

Since the aim of the study is to illuminate a perception of Spanish/English bloggers, the semi-structured online interviews were conducted (Mann \& Stewart, 2000:75). In particular, the object of the study is a person who is behind the blog site: a blogger. Online written interviews seemd to be the best option to understand firsthand the social function of the Euroblogosphere inside the context of the EPS. The selection of twelve Spanish and English bloggers - six for each language - was made in order to give a study a broad and comparative dimension. With the sample of bloggers of two different languages, and - a priori - two different styles of political blogging, the study offers more nuanced analysis and more robust picture.

In order to select the blogger the biggest aggregator of the EU blogs (bloggingportal.eu) was used as a poll. The selected bloggers share the following characteristics: (1) are listed in bloggingportal.eu; (2) write mainly in Spanish/English; (3) are users of Twitter, with more than 300 followers; (4) focus mainly on European affairs; (5) published their last post no later than 3 months ago; (6) have a personal blog domain; and (7) speak on their own. 
Following a sampling illustratively strategy (Mann \& Stewart, 2000:126), one should assume that the result of the research is not an absolute truth that can be generalized to all blogosphere. Using the overview for planning and preparation procedure for qualitative interviews developed by Jenifer Mason (2002:75), a questionnaire with ten main questions and several sub-questions was created and sent to the bloggers' personal emails (in English or Spanish). Some of the questions provided an opportunity to present some comments by the bloggers. The methodology of data-driven coding (Kvale \& Brinkman, 2009:205) was used during indexing, coding, and categorization of the data.

\section{What do the bloggers say?}

\section{The influence of the Euroblogosphere}

The bloggers coincide in two points. The first one is that in general the Euroblogosphere is not big enough yet to be influential in any topic. James, an English speaking blogger perceives the Euroblogosphere as: "Still small, still very few participants," and José María, a Spanish speaking blogger points out: "[...] It is very much atomized." 1

The second common point shared by the bloggers is that the Euroblogosphere has a huge potential for setting the agenda: "Given that a public sphere is all about public communication, blogs can definitely play a very important role in both shaping and dominating the general debate" (Protesilaos, an English speaking blogger). However, the blogger Pau Solanilla claims the opposite: the Euroblogosphere lacks an ability to influence a selection of the topics. According to Pau, the Euroblogosphere, is a "microcosmos of multiplicity of isolate opinions," an atomized space without any kind of organization.

The main question here is what the Euroblogosphere needs in order to be more influential. There is a diversity of opinions among the interviewees, but in general they express that the Euroblogosphere needs more integration and cooperation between them: "Building links by promoting a culture of reading widely might increase the size and participation of the Euroblogosphere, and so the Euroblogosphere may become more influential" (Conor, an English speaking blogger).

Some bloggers compare the European blogosphere and the US blogosphere. The US blogosphere seems to be, in their opinion, more influential. According to the interviewees, some the US bloggers have a huge potential in affecting the mainstream media and itroducing the issues to the public debate. In Europe, as interviewed bloggers claim, there is almost no individual blogger who have such a huge influence:

${ }^{1}$ Original in Spanish: "Está muy atomizada." 
“The EU blogosphere remains a rather elitist talking shop between young academics and EU professionals. Secondly, and related to the first point, there are few connections between the European blogosphere and established national media which could allow blogposts to reach a wider audience in one of the member states. Other than in the United States, it rarely happens that an EU blogger's post inspires an article in a national newspaper."

[André, an English speaking blogger]

\section{The European Public Sphere and a role of blogs in the online EPS}

Both contributions: of the bloggers to the Euroblogosphere and of the Euroblogosphere to the EPS seem to be evident for the bloggers. According to them, the Euroblogosphere bears a responsibility of developing debate and sharing information. However, this contribution is very small if we take into consideration all the channels of communication the citizens may potentially use (newspapers, radio stations, etc). Also, the interviewees' general claim is that although the Euroblogosphere has grown in size, and some sort of influence, it is still very narrow and elitist:

"Bloggingportal.eu may list around 1000 EU-focused blogs, but most aren't regularly updated (my own included), and the vast, vast majority would struggle to get daily readership numbers in triple digits. It's now become a closer-knit community (partially through Bloggingportal, as there's now a core of c.25 Eurobloggers who are all (theoretically) editors on that site who all email each other fairly regularly."

$$
\text { [James, am English speaking blogger] }
$$

There is not entire unanimity of what role the Euroblogosphere has to play inside the EPS, however the participants think that the Euroblogosphere is a space where everyone can have a voice and can express their ideas, regardless of their own worldviews. Furthermore, every blogger, but one, believes that the EPS is not existing yet but still developing. Indeed, only one interviewee claimed that "As an elitist concept, I think the European public sphere already exists and brings people from different cultures together under a common umbrella" (André, an English speaking blogger).

Among the others, one may distinguish between two opinions: while some expressed their doubts whether the EPS will ever be developed, the others hoped that it would be developed in future. The former name stumbling blocks such as a lack of the political union and of a transparency of the EU political institutions. Consequently, since the citizens do not feel they can participate in their actions and control politics, is very hard to engage them and to create debate.

The later discussed conditions that must be met to develop the EPS. Some bloggers think that there must be a common institutional policy to make the citizens 
feel that the institutions are for them and not just for national leaders in Brussels. The others recognize a need to show people how the EU affects them, in order to create interest:

"People will care about the EU when they know that they are directly affected by it - and a very good way for that to be realized is through direct taxation. Once you get European-level taxation, you will get European-level discussions on how to reform the executive and legislative branches of the EU, how to decisively address the democratic deficit, how to make everything more approachable, understandable, transparent and human. Yes human, since now everyone is acting like an emotionless drone, thanks to the kind of 'super-official' status EU institutions have."

[Protesilaos, an English speaking blogger]

Other blogger José María argues that the EU must be listened, by "imperative". His proposition is to launch a series of TV commercials to explain what the EU is doing: "Now is when the Union must commit itself to be heard and seen on radio and television, even by legal imperative that public television must run the ads the Union considers. Citizens must feel close to their institutions as they have been created by and for them." 1

One part of the questionnaire included questions about the relations between the European Public Sphere and democracy. For some scholars the public sphere is central precondition for democracy because it enables widespread public debate (Fossum \& Schelesinger, 2007:4). Scholars have consistently stressed that an important component of the EU's democratic deficit is the absence of the viable European Public Sphere.

Regarding this point, the bloggers stated that democracy and the EPS need each other. In other words, there cannot be democracy without the public sphere, and there cannot be public sphere without democracy. What is clear is that in this process the blogs are an element of democratization, and a necessary element to create a public debate: "I think this is absolutely true. No democratic debate, no democracy, it's that simple" (Craig, an English speaking blogger).

\section{The role of the European institutions and institutional aspects of media}

Some of the bloggers think that the European institutions must participate in some sense in a public debate by providing a framework, but never actually interfering with it. Other bloggers think it is better that European institutions are totally out of

\footnotetext{
1 Original in Spanish: “Ahora es cuando la Unión debe apostar por hacerse escuchar y ver en radios y televisiones, que incluso por imperativo jurídico las televisiones públicas deban emitir los anuncios que estime la Unión. La ciudadanía debe sentir cerca a sus instituciones pues han sido creadas por y para ella."
} 
any kind of management, organization or creation of framework for debate. These bloggers think the public sphere must be developed just by the citizens. If the EPS has not been developed so far, it is because citizens are not ready yet. For the bloggers, the EU needs to change, if we want the EPS to be launched.

In that sense, the Internet has the potential to improve public communication. As it was mentioned by the bloggers, institutions should try to communicate and make the citizens feel that institutions are for them. In order to get close to democracy, institutions must be sensitive with the reality and problems to keep in touch with people by elections and referendums.

The bloggers agree that the Internet is the best way to communicate and to create debate. However, it is a very elitist channel of communication and the number of users is still rather low compared to traditional media, such as TV, radio, and newspapers. A significant advantage of the Internet is that everybody can have a voice. It is good that citizens can have a channel of communication to stand up and to organize themselves. Furthermore, the Internet offers alternative sources of information and supports a diversity of opinions.

On the other hand, the Internet might be perceived as a source of unreliable information. As the bloggers see it, the Internet loves extremism, and it is more common to find euro-skeptic comments as it is a easy way for the people with these ideas to express them. These comments and not accurate information are spread very fast and might create a false image of the EU. Furthermore, aside of publishing their own material they explicitly comment the Europhiles blogposts: "[...] The proliferation of Euroscepticism can be virulent in some countries, and can be spread easily on the Net, sowing the seed of populism, so easy to turn in times of severe economic crisis"2 (Eva Peña, a Spanish speaking blogger); “If a medium says one thing, the citizen can immediately check it on the Internet"3 (Macarena, a Spanish speaking blogger).

The bloggers, in the opinion of the interviewees, can contribute to such a discussion, but there are many other groups of people who can do it as well. Namely, members of associations, or local media might contribute to the EPS. The question is whether all of them share the same concept of the EU and the EPS.

Some interviewees suggest that bloggers could be somehow 'employed' by the European institutions to promote pan-European debate. Another interviewee indicates that policy-makers fail listening to the Internet. In this case the Internet is viewed by the bloggers as a forum where all opinions are expressed and where institutions and organizations can learn. Additionally, the interviewee expresses that bloggers can provide a feedback from citizens to the European institutions.

\footnotetext{
2 Original in Spanish: "La proliferación de un euroescepticismo que puede ser virulento en algunos países, y puede contagiarse fácilmente por la Red, sembrando la semilla del populismo, tan fácil de prender en épocas de grave crisis económica."

3 Original in Spanish: "Si un medio dice una cosa, el ciudadano puede inmediatamente comprobarlo en internet."
} 
Finally, the bloggers agree that media such as TV, radio, or newspapers play a role of gatekeepers and control a flow of information. Furthermore, the information provided by the traditional media is domesticated. All these factors limit the role of bloggers.

\section{Discussion}

The Euroblogosphere can be seen as a current embodiment of the public sphere in Europe, but on a rather small scale. It means that the Euroblogosphere fulfills the characteristics of the European Public Sphere, and by examining the Euroblogosphere one can grasp a contemporary reality of the actually existing EPS. Within the Euroblogosphere people may virtually meet exchanging ideas and thoughts. Anyone can start a blog and publish opinions about European topics, regardless of his or her economic, social or identity background. There is not limitation or filter to any citizen to spread content and all of them share the same possible audience.

According to the Eurobloggers, their population and strength is growing slowly as they are present not only at the bloggingportal.eu website, but also at the conferences, seminars, or talks. ${ }^{4}$ Also, at least some of them start to be influential in politics by providing a criticism on political decision or decision makers. At the same time, the bloggers, like scholars, do not share one single model of the blogosphere or the EPS. Eriksen (2005:351) explains that is difficult to reach a common EPS in the foreseeable future, but that there are traces of a segmented EPS. In fact, a small community of citizens specialized and interested in the European issues who interact on various levels (local, regional, national, international and transnational) can develop such a sphere.

In this paper two models of EPS were presented in order to describe the Euroblogosphere in their respective contexts. It seems that a current version of the Euroblogosphere should be placed between these two models. Euroblogosphere has developed from being focused nationally to start an interaction within other countries, in a pan-European debate. It has grown in size and specialization, although nowadays the Euroblogosphere is facing a problem of deepness of discussions. Internet and the social media have changed the behavior of reading and writing, promoting the speed of information more than the argumentation of the information.

The experience of the bloggers provides arguments for those who are studying the Euroblogosphere and try to recognize its contribution and position inside the EPS. Bloggers show that there is a real intention to build the European blogosphere where people can share thoughts and expressions despite of their economic, politi-

${ }^{4}$ Bloggingportal.eu has been contacted by the EU representation of Cyprus in Brussels to organize a meeting. "Cyprus Presidency meeting with bloggers: Call for involvement!," Bloggingportal.eu, accessed July 29, http://www.bloggingportal.eu/blog/cyprus-presidency-meeting-with-bloggers-call-for-involvement/. 
cal or religious backgrounds. Only with more engagement from the bloggers and together with other associations and groups, online and offline, the European Public Sphere can be developed.

The study on Eurobloggers leads to a conclusion that the Euroblogosphere is a factor supporting the political participation by integrating more people and more voices. Blogging has shown to be very important for the interviewees as a way of expression, keeping an eye to the European institutions and any other companies, or NGOs.

European institutions should pay attention to debates on both - national and international (European) levels and the role of the Internet such a communication processes. Regarding this point, Margot Wallström, ex Vice-President of the European Commission responsible for institutional relations and communication strategy, said: "I believe the Internet is the new channel for debate and communication. The EU needs to get more into the blogosphere and engage in real debate" (Walström, 2012). However, despite of the Euroblogosphere and the Internet, traditional mass media still will be the main sources for citizens to gather information.

Finally, we should consider other tools bloggers are using nowadays in order to interact, such as Twitter and Facebook. Live blogging also seems to be more and more important, as an example of the live blogging of the last EU summit celebrated 29 of June showed (Rachman, 2012).

\section{Conclusions}

While much scholarship has focused on the media, less is known about the audience and the authors of the messages (Sicakkan, 2012:105; Statham, 2010:299). The aim of the research was to study opinions and experience of the bloggers. This study provided findings that support our understanding of the Euroblogosphere and the European Public Sphere. The bloggers give evidence of an actor-based online European transnational blogosphere by describing the existence of a community of individual citizens that share information and thoughts about the European topics. The website bloggingportal.eu is just one platform with hundreds of blogs, and hundreds of websites, projects and platforms fostering for more integration and European project. However, the Euroblogosphere is, still rather small, elite, and limited by language differences.

The European elections in 2014, or any other big political event in Europe, might be the best moment to conduct a research how and why EU-oriented bloggers interact across Europe and what is a significance of bloggers for political participation and influence. In addition, further research on the Euroblogosphere might explore other languages, or nationalities, and other platforms of online discussions, such forums or social media in order to draw more detailed picture of the Euroblogosphere. 


\section{References}

Bahnisch, M. (2006), “The Political Uses of Blogs”, in: A. Bruns, J. Jacobs (eds), Uses of Blogs, New York: Peter Lang, 31-67.

Baumer, E. P. S., Sueyoshi, M., Tomlinson, B. (2011), “Bloggers and Readers Blogging Together: Collaborative co-creation of political blogs", Computer Supported Cooperative Work 20, 1-36.

Beus, Jos de. (2010), “The European Union and the Public Sphere. Conceptual Issues, Political Tensions, Moral Concerns and Empirical Questions", in: R. Koopmans, P. Statham, The Making of a European Public Sphere, Cambridge, 13-34.

Bohman, J. (2004), “Expanding Dialogue: The Internet, the Public Sphere and Prospects for Transnational Democracy", The Sociological Review 52, 131-55.

Bruggemann, M., Schulz-Forberg, H. (2009), “Becoming Pan-European? Transnational Media and the European Public Sphere", International Communication Gazette 71(8), 693-712.

Cyprus Presidency meeting with bloggers: Call for involvement!, Bloggingportal.eu, available at: http://www.bloggingportal.eu/blog/cyprus-presidency-meeting-with-bloggers-call-for-involvement/, accessed: July 29, 2013.

EP. Ep Newshub, available at: http:/ / www.epnewshub.eu, accessed: June 20, 2012.

Eder, K. (2007), “The Public Sphere and European Democracy: Mechanisms of Democratisation in the Transnational Situation", in: J. E. Fossum, P. Schlesinger (eds), The European Union and the Public Sphere. Communicative Space in the Making, New York: Routledge, 44-65.

Eriksen, E. O. (2007), “Conceptualising European Public Spheres: General, Segmented and Strong Politics", in: J. E. Fossum, P. Schlesinger (eds), The European Union and the Public Sphere. Communicative Space in the Making, New York: Routledge, 7-60.

Eriksen, E. O. (2005), “An Emerging European Public Sphere”, European Journal of Social Theory $8(3), 341-363$.

European Commission, 2013 Will Be the European Year of Citizens, available at: http:/ / ec.europa.eu/citizenship/european-year-of-citizens-2013/index_en.htm, accessed: May 13, 2012.

Feldhof, A. (2009), Atomization overcome? The role of the European blogosphere in fostering more European democracy, Bachelor Thesis, Maastricht University.

Fossum, J. E., Schlesinger, P. (eds) (2007), The European Union and the Public Sphere. Communicative Space in the Making?, New York: Routledge.

Gideon, R., "EU Summit: Live Blog", Financial Times, available at: http://blogs.ft.com/ the-world/2012/06/eu-summit-live-blog/?Authorised=false\#axzz20xPfd8NP, accessed: May 29, 2012.

GlobalFree (2011), Liquid Democracy, available at: http://globalfree.wordpress.com /2011/11/06/liquiddemocracy/, accessed: August 15, 2012.

Habermas, J. (2006), Political Communication in Media Society: Does Democracy Still Enjoy an Epistemic Dimension? The Impact of Normative Theory on Empirical Research, Communication Theory.

Habermas, J. (2012), Why Europe Needs a Constitution, New Left Review, avaliable at: http:/ / www.newleftreview.org/II/11/jurgen-habermas-why-europe-needs-a-const itution\#_edn2, accessed: January 30, 2012. 
Habermas, J. (1989), The Structural Transformation of the Public Sphere, Great Britain: Polity Press.

Henwood \& Pidgeon (1993), "Qualitative Research and Psychological Theorising", in: M. Haammerseley (ed.), Social Research, Philosophy, Politics and practice, London: Sage, 97-111.

Hermes, J. (2006), "Citizenship in the Age of the Internet", European Journal of Communication 21 (3), 295-309.

Hanlon, M., Lg Internet Refridgerator, avaliable at: http://www.gizmag.com/go/1132/, accessed: June 20, 2012.

Heller, M., Rényi, Á. (2007), “EU Enlargement, Identity and the Public Sphere”, in: J. E. Fossum, P. Schlesinger (eds), The European Union and the Public Sphere. A Communicative Space in the Making, New York: Routledge, 169-187.

Kaitatzi-Whitlock, S. (2007), “The Missing European Public Sphere and the Absence of Imagined European Citizenship", European Societies 9 (5), 685-704, doi 10.1080/14616690701412814, accessed: February 2, 2012.

Koopmans, R., Zimmermann, A. (2010), “Transnational Political Communication on the Internet", in: R. Koopmans, P. Statham (eds), The Making of a European Public Sphere, New York: Cambridge University Press, 171-194.

Koopmans, R., Erbe, J. (2004), “Towards a European Public Sphere?”, Innovation: The European Journal of Social Science Research 17 (2), 97-118, doi 10.1080/1351161042000238643, accessed: February 2, 2012.

Koopmans, R., Stathan, P. (eds) (2010), The Making of a European Public Sphere. Media Discourses and Political Contention, New York: Cambridge University Press.

Kvale, S., Brinkman, S. (2009), Interviews. Learning the Craft of Qualitative Research Interviewing, London: Sage Publications.

Mann, C., Stewart, F. (2000), Internet Communication and Qualitative Research, Sage Publications.

Mason, J. (2002), Qualitative Researching. Second Edition, Sage Publications.

Medrano, J. D. (2009), “The Public Sphere and the European Union's Political Identity”, in: J. Checkel, P. Katzenstein (eds), European Identity, Cambridge: Cambridge University Press, 81-109.

Michailiodou, A. (2009), "Vertical Europeanisation of Online Public Dialogue: EU Public Communication Policy and Online Implementation", in: C. Bee, E. Bozzini (eds), Mapping the European Public Sphere: Institutions, Media and Civil Society, Ashgate, 65-82.

Ondarza, M. (2007), The Euroblogosphere - Advent of a Social Movement or Source for Expert Information?, Hamburg: Master Thesis.

Papanagnou, G. (2013), “Digital Publics in Transnational Spaces: EU Blogs and the European Public Sphere", in: Working Group Report W-2013/6, United Nations University. Centre for Comparative Regional Integration Studies.

Papacharissi, Z. (2004), "Democracy Online: Civility, Politeness, and the Democratic Potential of Online Political Discussion Groups", New Media and Society 62, 259-83.

Patz, R., Preparing the \#rp12: Search in the multilingual Euroblogosphere, avaliable at: http:/ / polscieu.ideasoneurope.eu/2012/03/23/preparing-the-rp12-search-in-themultilingual-, accessed: July 25, 2012.

Risse, T., Van de Steeg, M. (2003), An Emerging European Public Sphere? Empirical Evidence and Theoretical Clarifications Conference Europeanization of Public Sphere, Political Mobi- 
lisation, Public Communication and the European Union, Sciences Centre Berlin, June 20-22, 2003.

Ruiz Soler, J. (2012), Who blogs what? A qualitative study on the role of the Euroblogosphere in a context of a European Public Sphere, Master Thesis. Lund University, available at: http:/ / www.lunduniversity.lu.se/o.o.i.s?id=24923\&postid=3055506, accesed: September 10, 2013.

Schmidt, J. (2006), Eine kommunikationssoziologische Studie, Konstanz, Germany: UVK Vertragsgesellschaft $\mathrm{mbH}$.

Sforza, T., Blogging: The Saviour of Europe?, avaliable at: http://www.cafebabel.co.uk/article/17136/blogging-the-saviour-of-europe.html, accessed: February 2, 2012.

Sicakkan, H. G. (2012), “Diversity, Polity, and the European Public Sphere”, Javnost The Public $20(1), 5-17$.

Statham, P. (2010), “What Kind of Europeanized Public Politics?” in: R. Koopmans, P. Statham (eds), The Making of a European Public Sphere, New York: Cambridge University Press, 277-306.

Van de Steeg, M. (2009), “Theoretical reflections on the Public Sphere in the European Union: A network of communication or a political community?" in: C. Bee, E. Bozzini (eds), Mapping the European Public Sphere: Institutions, Media and Civil Society, Ashgate, 31-46.

Wallström, M., Communicating a Europe in Stormy Waters: Plan D, available at: http:/ / europa.eu/rapid/pressReleasesAction.do?reference=SPEECH/05/396\&format $=$ HTML\&aged=1\&language=EN\&guiLanguage=en, accessed: June 19, 2012.

Wessels, B. (2009), “The Public Sphere and the European Information Society”, in: C., Bee, E. Bozzini (eds), Mapping the European Public Sphere: Institutions, Media and Civil Society, Ashgate, 47-63.

Wright, S. (2007), "A Virtual European Public Sphere? The Futurum Discussion Forum”, Journal of European Public Policy 14 (8), 1167-1185.

Wright, S., Street, J. (2007), “Democracy, Deliberation and Design: The Case of Online Discussion Forums”, New Media Society 95, 849-869. 



\section{Part II}

Media and Political Communication in Europe 

Beata Ociepka

University of Wrocław, Poland

\section{International Broadcasting: A Tool of European Public Diplomacy?}

Although public diplomacy is in fashion in Europe nowadays, there is no agreement how the term should be understood. The definition is elusive, and in consequence many researchers equalize it with propaganda or international public relations. Governments and academia develop their own understandings. I represent the opinion that after the collapse of the bipolar system and because of the inclusion of nongovernmental actors into international relations, a new public diplomacy model is emerging. The profound changes in the patterns of international communication contribute to this development. In Europe public diplomacy has been included into strategies of foreign policy during the last decade. The research has to follow up this development urgently as European countries and the European Union display important actors in international politics and international communication.

From the perspective of political communication research, public diplomacy is a strategy of international political communication that is adopted by democratic countries with open media systems. It materializes as a choice of the strategy of international communication, including branding and basic tools of public relations. However, there is no agreement whether, an international broadcasting makes a constitutive element of public diplomacy. In this paper I will follow the P. Taylor's (2011:27) approach, that perceived cultural diplomacy and international broadcasting as essential parts of public diplomacy.

The question about the nature of relation between public diplomacy and international broadcasting based on American experiences was posed by M. Price (2003). Price analyzes Voice of America (VoA) and Radio Free Europe (RFE). His findings might be adopted nowadays to the contemporary US broadcasters: Radio Sawa and television Al Hurra as components of American public diplomacy model. In 2010 A. O'Keeffe and A. Oliver - researchers from Australian think tank Lowy Institute - in a report "International Broadcasting and its Contribution to Public Diplomacy" shed some light on the governmental investments in international broadcasting in order to prepare recommendation for Australia as a middle power and to lift Australian international broadcasting profile ( $\mathrm{O}^{\prime}$ Keeffe \& Olivier, 2010). The report convinces that not only big powers include international broadcasting into the soft power tools. Also J. Bahrke in his study on German Deutsche Welle shares the opinion that public diplomacy contains international broadcasting (Bahrke, 2010:198). 
In the approach presented in this paper, the new public diplomacy is a tool of soft power. The next fashionable term coined by J. S. Nye (2004) comprises in my research not only culture, values and foreign policy, but also the soft lining of economic power. As such, it derives much from public relations and reflects economization of foreign policy. Thus, I understand public diplomacy in its new, post cold war version, as a dialogical form of international political communication, and a tool implemented by foreign policy in order to position the state internationally. Image and public opinion are the most important terms for understanding the contemporary public diplomacy. The stress put on symmetry, dialogue, listening and engaging characterizes approaches close to public relations. R. Zaharna names new symmetric public diplomacy a relational model, opposite to informational onesided public diplomacy (Zaharna, 2007). There is a question whether international broadcasters, stemming from the era of mass communication, are able nowadays to serve as tools of dialogical public diplomacy.

Public diplomacy will be defined as a form of international political communication aimed at foreign publics. As such, it supports the achievement of the goals of foreign policy of the state and includes non-state actors in the process and integrates cultural diplomacy and international broadcasting. The aim of public diplomacy is to create or reinforce a positive image of the country and its society and to make the achievement of international policy goals easier by influencing public opinion to shape positive attitudes toward the country. It should be understood as a long - term, symmetric, dialogical communication of governments and NGO's with broad audiences (stakeholders) abroad. The communication frame attributes to the governments communicators' role, which due to the logic of symmetric communication includes both sending and receiving messages. Political international communication is understood, as in the Denton and Woodward's concept (1990) as a process of cross border flow of messages, engaging participants in debate on allocation of goods, privileges, regulations needed for achievement of common good. Consequently, public diplomacy might be analyzed as a process aimed at setting the agenda of media (international broadcasting), politicians (government to government level) and the agenda of audiences (government to people, and people to people).

Cynthia Schneider (2004) describes public diplomacy as "all a nation does to explain itself to the world." It might therefore be understood as a narration that the society presents abroad - a story the society has to tell the world, filtered through the political goals of the country, government, or incumbent political party. National versions of public diplomacy give insight into the way societies translate their culture by using the means of international communication and cultural diplomacy. International broadcasters are channels for spreading the stories of societies.

The main idea of this paper is to analyze international broadcasting as one of the elements of new public diplomacy in Europe. European countries pioneered the use of radio for foreign policy purposes, in the beginning as both means of informing 
Diaspora (or colonial populations) about the politics at home and of foreign (war) propaganda. When the Soviet Union collapsed and the cold war was over, foreign image policy became no less important as an objective of international broadcasting. Despite the fact that global communication, relying on networks of information flow, defines a new context for broadcasting for foreign policy goals, radio and television still remain important tools of political communication. By the online access governments reach and engage new target groups. Furthermore, international broadcasters are identified with the country and count as icons of soft power, as it is in the case of $\mathrm{BBC}$, one of the most prominent and credible global broadcasters, identified with the UK and contributing to the positive image of the country.

In order to analyze the position of international broadcasters nowadays and to understand their relationships with Foreign Ministries, I will focus on three cases: (1) the British (BBC World Service), because of the long tradition of international broadcasting of the BBC and the company's (still) high international prestige; (2) the German (Deutsche Welle, DW), as DW seems to play important role as a tool of German foreign cultural policy; and (3) the Polish (Belsat TV), because Poland is a newcomer in public diplomacy and Belsat TV, aimed at Belarusian audience, makes an exceptional project authorized by a middle size country.

Polish case will be purposefully confronted with the experiences of two bigger states, which are much more significant in international broadcasting. The size of the countries matters - their hard assets contribute to the quality and territorial and linguistic reach of their international broadcasters. Their international position is reflected in the strategies and objectives of their international broadcasters. Therefore, Polish international broadcasting profile has been and will be different than British and German and there is no attempt in the study to equalize the cases. The main idea is to draw conclusions from three cases to understand the place of international broadcasting and its relevance in the European model of public diplomacy. Thus, the stress is put on the members of the $\mathrm{EU}$, not at the EU as an actor of international communication.

All three countries are members of the EU (Poland since 2004). However, their international positions are not the same with Poland as a country striving for a role of a middle power and a regional leader among Eastern members and neighbors of the EU. Polish language does not play the role of the language of wider communication as English and German do - it also affects broadcasters' performance. In the United Kingdom and in Poland international broadcasting is operated by public service broadcasters. Also DW is an institution of public law.

In the UK, the BBC is acknowledged as an official partner of the government in the field of British public diplomacy. In Germany, the Deutsche Welle plays a role of a go-between organization (Mittlerorganisation) of German foreign cultural policy. ${ }^{1}$ In the case of Poland, the role of public service radio and television in public diplo-

1 The term public diplomacy is not widely used in German foreign policy, instead the notion of foreign cultural policy is implemented. 
macy has not been defined yet due to the relatively short period of the development of this field. Nevertheless, while Western countries cut their budgets for international broadcasting, Poland launched in 2007 a new channel broadcasting to Belarus - Belsat TV. The station follows the idea of democracy promotion as an essential issue of European normative power. In contrary to the BBC World Service, or DW, Polish international media do not compete with other global media broadcasters.

The British, German and Polish public service institutions rely on governmental subsides and license fee financing. Therefore, they are supposed to follow the instructions of governments in international broadcasting. In particular, they are expected to broadcast messages serving the country's promotion, as well as to be involved in development cooperation (Official Development Aid, ODA) and democracy promotion. It may, potentially, affect the media impartiality. One of the presumptions of this study is that public service broadcasting itself is proliferated by the EU media assistance as a model for countries undergoing transition to democracy.

International communication as a frame of analysis of public diplomacy stresses the role of the government. The changes in the international environment - described by Arquilla and Ronfeldt (1999) as the emergence of a noosphere - signalize still important, although changing role of the state in international communication and public diplomacy. The role of the state is weakened by the growing participation and significance of non-state actors of international relations (international communication). On the one hand, the development of the media sphere defines the limits of controlling function of the state in public diplomacy. On the other hand, new technologies constituting the virtual public sphere supply the governments with new tools to put the citizens under their surveillance. Symmetrical social media that are prone to share, to involve, and to mobilize respond well to the model of relational public diplomacy.

\section{British Broadcasting Corporation (BBC)}

British public diplomacy is globally recognized as an outstanding example of foreign policy soft tool in a democratic country. British public service broadcaster (BBC) is an essential asset of UK's normative power. BBC Royal Charter (2006) explains the role of British international broadcasting as "bringing the UK to the world and the world to the UK." BBC World Service (BBC WS) is one of the most prominent international broadcasters globally. It won this reputation during the Second World War, while sending radio information to the US (Cull, 2010) and afterwards during the Cold War broadcasting to the Communist bloc (Leonard, 2002). The officials of BBC as well as researchers in international communication often quote Kofi Annan, to display the global prominence of BBC. The former UN Secretary General evaluated BBC as "British greatest gift to the world in the 20 ${ }^{\text {th }}$ century" (Dyke, 2003). 
Nowadays, BBC World Service consists of television, radio and online news and information. It has been funded by the Foreign and Commonwealth Office (FCO). According to the BBC World Service Agreement, BBC operates BBC World Service under the BBC Trust and in agreement with the Foreign Office. FCO has the right to agree strategy of the BBC WS and to close services. Both institutions agree on Three Year Plans, deciding on financing (BBC WS Broadcasting Agreement). Thus, the financing by the FCO will be over in 2014/2015. After that moment, BBC will cover World Services from the license fee. The close relation of the BBC World Service to FCO is counterbalanced according to the BBC Royal Charter and the Agreement (above) by the independence of $B B C$, granted also for World Service. BBC World News - one of the mostly recognized broadcasters worldwide and BBC's most watched - is a separate commercial channel of the BBC.

BBC World Service (2013) consists of 31 language radio services and two television stations, broadcasting in Arabic and Persian (launched respectively in 2008 and 2009). Their start was the reason for closing other (as Polish, operating in years 1939-2005) language sections. Arab Spring in 2011 proved that the decision to launch the Arabic service was taken right on time. The BBC Director for Global News Peter Horrocks reported in 2012 that the number of Arabic version viewers grew significantly during the Arab Spring. He outlined:

"The consequence of the BBC successfully blending traditional journalistic values with modern means of gathering and delivering news has been a noticeable increase in respect from our audiences in this region. Among BBC Arabic TV audiences, trust in us is up from 67 per cent in 2008 to 90 per cent in 2011."

Even after the viewing was not possible, the audience switched to $B B C$ radio in Arabic. According to Horrocks (2012), the trust originates from "impartiality and independence (...), accuracy and depth [of coverage - BO]; transparency (...) and accessibility (...)." Trust contributes to the credibility of the broadcaster and in the consequence to the credibility of the country. It should not be overlooked that credibility as a value is currency of soft power. Winning credibility will be essential for middle size countries, striving for recognition internationally, but it preserves significance also for the UK as a former Empire.

The positive perceptions of the BBC World Service stressed by K. Annan or Directors of the BBC are supported by international surveys. The Lowy Institute report from 2010 relates to one of them emphasizing that:

"In an effort to demonstrate the effectiveness of the BBC's international broadcasting operations, the BBC commissioned a survey in 2010 on attitudes to the BBC and other international news services in Kenya, Egypt, Pakistan and Turkey. Respondents were asked which British organizations and programs make them think more or less positively about the country, including the armed forces, the British Council, the UK Government and UK foreign aid. According to the Director General of the BBC, 
Mark Thomson, 80 per cent of respondents said that the BBC made them think more positively about the UK, far more than any of the other British institutions mentioned, including UK foreign aid."

[O'Keeffe \& Olivier, 2010:312; Thompson, 2010]

BBC is officially named a partner of British public diplomacy, next to British Council and Wilton Park. The close relationship with the FCO, outlined in the BBC World Broadcasting Agreement, is supported by sharing the same objectives, as defined for public diplomacy and for the BBC World Service: supporting positive image of the country and engaging with publics. Although engaging with publics seems to be difficult for a radio and television station, it might be achieved by the online services, generating feedback from viewers and providing them with in-depth information and deeper contexts of issues discussed and presented in the programs. The role an international broadcaster might play in the country's public diplomacy was illustrated well with the case of BBC in Poland by Mark Leonard in a book on public diplomacy. BBC was mentioned twice by M. Leonard among the strengths of UK public diplomacy in Poland as "highly regarded for its role during Communism" and BBC World Service in Polish (not existing any more, see above) as "widely recognized (...), respected for its quality and trustworthiness, (...) the highest - quality news provider in Poland" (Leonard, 2002:138).

$\mathrm{BBC}$ contributed a lot, due to its prominence in Poland, to the inclusion of international broadcasting into Polish democracy promotion aimed at Belarus. As it was stated above, documents of BBC World Service put much stress on its editorial independence (Review, 2005). FCO and BBC express it in every official document as the core value of British international broadcasting. Nevertheless, international broadcasting seen as an instrument of public diplomacy imposes limits to journalistic independence. Still, the good reputation of BBC, reflected in the opinion surveys, seems to confirm that the broadcaster found the balance between serving the objectives of the FCO and respecting the core value of journalism. $\mathrm{BBC}$ engages also in media assistance, partly thank to BBC Media Action. This international charity of $\mathrm{BBC}$ provides - while supporting media and access to them - to social change abroad. The international involvement of BBC Media Action (www.bbc.co.uk/mediaction) illustrates how the official public service partner of the FCO in the field of public diplomacy has been included into development aid (media assistance).

The promulgation of the British model of public broadcasting itself turned to an important asset of British soft power and BBC itself to a myth of democratic and independent media, influencing among others Central and Eastern European countries undergoing transition after 1989. The model constitutes now British but also European normative power even if its spread was stopped on the Eastern borders of the EU. The similar objectives in the field of media assistance are attributed to German and Polish foreign broadcasters. 


\section{Deutsche Welle (DW)}

In Germany, the objectives of international broadcasting are explained in the Deutsche Welle Act (Deutsche - Welle - Gesetz, 2005): DW is:

“...intended to convey the image of Germany as a cultural state in the European tradition and as a free and democratic constitutional state. (...) should provide a forum in Europe and on other continents for German (and other) points of view on important topics, primarily in the areas of politics, culture, and economics, with the aim of promoting understanding and the exchange of ideas among different cultures and peoples. In so doing, Deutsche Welle shall, in particular, promote the German language."

These objectives follow up the main concept of German foreign cultural policy as outlined in "Konzeption 2000" - basic document of German Foreign Office in 2000. “Konzeption 2000" defines Deutsche Welle as one of the main actors of German foreign media policy. The role of DW as a part "of German foreign relations, but not as a part of German foreign policy" was stressed in the document evaluating the broadcaster in 2008, presented to the German Bundestag (Unterrichtung, 2009:3). The formulation emphasizes the distance from German Ministry of Foreign Affairs.

The history of German international broadcasting is to some extent dominated by the notoriety won by German Nazi radio propaganda during the Second World War. After 1949, West German media gained better reputation internationally engaging in conflict areas and in transition countries, while substituting missing impartial sources of information. J. Bahrke claims that during the military rule in Greece Deutsche Welle was "the only not censored broadcaster, which could have been listened to in Greece in Greek language" (Bahrke, 2010:198). For the listeners of the Communist bloc, the programs of DW before 1989 were much less relevant than VoA, RFE and BBC (Ociepka, 2013:90).

Deutsche Welle was established in 1953. In 1960 its operation was regulated by DW Act and in 1962 it became a member of German public service broadcaster ARD. DW represents Germany and promotes German culture abroad. It is supposed to cater for growing presence of Germany internationally. This obligation rests on the concept of Germany as "a nation rooted in European culture" as the key message of German foreign image policy. Deutsche Welle is a media visiting card of Germany (Unterrichtung, 2009:3-4).

Since 1992 it has been operating also as television, nowadays it broadcasts in 30 languages. The television service broadcasts to North America, Asia, Australia and Africa in English, whereas the program for Europe is split into English and German services, and for Latin America into Spanish and German. There is also a service in Arabic and English for North Africa and Near East. Although German serves as a language of wider communication, the governors of DW decided on adding English to the basic offer of the television and online services. Nevertheless, promotion of German language is still one of the most important objectives of DW. 
Deutsche Welle engages in media assistance. Deutsche Welle Act obliges the broadcaster to participate in German development cooperation, particularly in democracy promotion. DW's financing comes partly from the federal budget for development aid (Unterrichtung, 2009). DW has been providing courses and vocational training for journalists in developing countries since the mid-1960s. Along with the new public diplomacy concepts, DW searches for longstanding cooperation with stakeholders abroad. According to the information given on the website of the broadcaster, about 3,000 people every year are involved in trainings offered by DW. They constitute "a global network for Germany". Many of the participants of DW's projects and programs are future opinion leaders, essential members of public diplomacy networks. The broadcaster claims that it engages with and listens to the audiences, fulfilling the main objectives of an intermediate of a new symmetric public diplomacy.

Deutsche Welle plays the role of a go - between in German foreign cultural policy. As it was stressed above, German Ministry of Foreign Affairs rather scarcely uses the term public diplomacy. Still, foreign cultural policy makes one of the three pillars of German foreign policy. Since 2000, it has been implemented as means preventing conflicts. By engaging and listening, foreign cultural policy is supposed to contribute to conflict solving. DW values equate the values, Germany wants to share with the world. They are defined in Deutsche-Welle-Act from 2005 as well as in basic documents on German foreign cultural policy.

Deutsche Welle as an intermediary of German foreign cultural policy operates under Ministry of Foreign Affairs and Federal Government Commissioner for Culture and the Media. It is financed from the budget of the Commissioner for Culture and Media (Michalek, 2009:37). This pattern of financing gives Deutsche Welle some independence from the direct control of the Ministry of Foreign Affairs and supports the expectation that DW is a part of German foreign relations and not German foreign policy.

The position of German international broadcaster is not as strong, as the BBC World Service's. Traditionally, during the Cold War and after 1989 DW was geopolitically more focused on Eastern Europe, one of the most important regions for German language policy after 1982. Promotion of the language is in the case of DW weakened by the implementation of English in order to reach as large audiences as possible. Branding Germany and promoting the language require putting a stress on German culture while providing "a forum in Europe and on other continents for German (and other) points of view" and "promoting understanding and the exchange of ideas among different cultures and peoples" result in the use of English. DW follows the main objectives of German foreign policy strategy that potentially results in the clash between representing the governmental stances and the journalistic impartiality. Based on this case, Johannes Barke shares the opinion that public diplomacy contains international broadcasting (2010:198). 


\section{The Polish Case: Belsat TV}

Poland is a newcomer in public diplomacy but not in international broadcasting. Polish Radio External Service has been broadcasting abroad since 1936. In 2013 it broadcast in 6 languages. The language reach reflects differing priorities of Polish foreign policy during and after the Cold War. Under the communist rule Polish Radio broadcast mainly to Western European countries and offered service in Arabic. After 1989 a reallocation of geographic priorities to Eastern Europe took place. Polish Radio External Service informs about Poland, contributing to reshaping the country brand. The main document on promotion of Poland from 2009 (promotion was until quite recently the main term used by the Polish Foreign Ministry to describe efforts to use soft assets and economic diplomacy in foreign policy) signalizes the need to invest in radio and television broadcasting - including online service for the publics abroad - but it does not define the role of international broadcasters.

This part of Polish public diplomacy seems to be underestimated by the Polish Minister of Foreign Affairs (MFA). Belsat TV has been coordinated by an Advisory Council, consisting of representatives of Polish Public Service Television (TVP) and two MFA Departments: Department of Development Cooperation and Eastern Department. The Advisory Council limits its activity to very general intimations for the programming. Thus, it is not the Department of Public and Cultural Diplomacy of the MFA that coordinates Belsat TV on behalf of the Minister of Foreign Affairs. The objectives of the broadcaster were outlined in the agreement between the MFA and TVP reached in 2007. The agreement introduces supporting of "positive image of Poland abroad, especially in Belarus" next to democratic values promotion of a "good neighborhood" (Porozumienie, 2007). These objectives are in accordance with the remit of Polish public service broadcasters.

Neither BBC, nor DW broadcasts in Belarusian language. Belsat TV, broadcasting via satellite in Belarusian for Belarus and Belarusian minority in Poland, is of relevance as Belarus is an example of an authoritarian country, neighboring to the EU, with a closed media system, for which international broadcasting is a source of information about domestic and foreign policy. Belarus is also a receiver of development aid and many countries focus their promotion of democracy efforts on Belarus. DW offers news and information for Belarus in English and German. BBC WS operates radio program in Russian and Ukrainian. The first one reaches also Belarusians since a majority of them speaks Russian as a mother tongue. Belarusian is, according to UNESCO, one of the endangered languages (UNESCO, 2013).

Poland was a recipient of Western and American public diplomacy messages from the period of informational public diplomacy. The fact that it broadcasts now to Belarus might be seen as a follow up of the experiences of Polish society under the communist rule. The communist authorities classified Western broadcasters as a hostile propaganda, although the classification was not shared by citizens who 
used to search for political news from Voice of America, or the BBC. Based on its own experience as a recipient of democracy promotion campaigns, Poland launched Belsat TV.

Therefore, the launching of the channel is a considerable effect of Cold War Western international broadcasting. Belsat aims to compensate for the lack of uncensored information sources in Belarus. It is financed by the Polish Ministry of Foreign Affairs and partly by TVP. Online version gives Belsat opportunities to become an interactive medium. In this case online presence is a must as for many Belarusians it is the only way to receive not censored information about politics. Belsat reached $11 \%$ of Belarusian society in 2009 to almost 23\% in December 2010 and 16\% in Mai 2011 (Zerkalo-Info, 2011). The number of viewers increased in 2010 before and during presidential elections. The station was the first in the country which broadcasts the whole program in Belarusian. The language is associated with opposition to Lukaszenka regime.

Its viewers - according to surveys undertaken by Zerkalo-Info agency (2011) - were seeking alternative sources of information on politics. Both Belsat TV and its online version reflect the efforts of Polish public diplomacy to reach and attract the society, not Belarusian political elites. As $87 \%$ of viewers trust the station, and $60 \%$ of viewers explain watching because of the opinions different to official media, it makes an outstanding, oppositional source of information (Zierkalo, 2011). It can serve as a platform of public debate online, replacing official channels of information in Belarus. Belsat was supposed to contribute to social change in Belarus by providing Belarusians with information on politics not available for them at home via censored Belarusian media. The station supported the oppositional movement "Revolution via social media" that organized demonstrations in a form of flashmobs in Minsk in 2011. Belsat, due to its growing audience online and a high level of trust, illustrates the opportunities online media provide for democracy promotion. It potentially creates an issue alliance for Belarusians searching for information on politics online and for individual, and NGOs interested in supporting social change in Belarus.

Although the channel is recognized as Polish only by 13.9 per cent of viewers (Ponad, 2012) it preserves relevance for public diplomacy purposes in long term, which responds well to the relational model of new public diplomacy. Live streaming of Belsat TV is followed by accounts on social media as Twitter, Facebook and You Tube. You Tube makes a natural place for Belsat presence.

There are also two radio stations broadcasting from Poland to Belarus, supported by the Polish MFA and the EU (Radio Racja, and European Radio for Belarus). Television and radio for Belarus follow the idea of American and Western European radio stations during the Cold War, operating for social change in authoritarian systems. Providing alternative information on politics to Belarusian sources, Belsat promulgates the core values of the EU - such as democracy and freedom of the press. However, because of the cultural identity of Belarusian society, Russian media seem to hold more appeal. 


\section{Conclusions}

International broadcasters presented above are members or divisions of national public service radio and television. All three share basic values of European public service broadcasters such as impartiality, catering for minorities, as well as for all tastes and interests. There is no conflict between these values and international objectives of broadcasters. The other thing is an institutional autonomy relevant for the public service broadcasters' operations and, in consequence, for relations between media and foreign policy. As it was outlined above, there are some governmental guarantees for programming independence. For example, BBC WS emphasizes journalistic independence as the core value and the reason of the broadcasters' global prominence. Usually, the broadcasters are given the same structure as national public service radio and television. Belsat TV makes an exception by being structurally closer to the MFA, than BBC or DW. Financial autonomy is not less relevant. All three broadcasters suffer from cuts and reductions and all but BBC World Service from 2014/2015 depend on the stately budget. When international broadcasting is financed from the license fee, the domestic public should be informed about the programming. The host country's audience is often not aware of international operations of their national public service broadcasters (Meyen \& Scheu, 2011:116). It is one of the tasks of the new public diplomacy at the domestic level to inform the public at home about the strategy of international broadcasting.

All three countries reduced numbers of language services in last ten years, investing in the same moment in new target audiences as Arabic and Persian in the case of BBC, Belarusian in Polish case, and Spanish and Arabic in the case of Germany. Investing in Arabic and Persian services paid off during the Arab Spring in 2011. Still, governmentally funded broadcasters, operating in more and more competitive media sector, have not been the unique players worldwide any more. Commercial broadcasters joined the competition in proliferating global news. The same relates to big powers, who used to be the main players in the past. Nowadays more and more smaller countries develop their international broadcasting media, usually combining satellite access with online services. The launching of Al Jazzera's service for the US in August 2013 symbolizes the changes in the landscape of global communication. Despite technological revolutions, radio has been supported by governments as it preserves its relevance in such regions as Africa, and in specific circumstances (such as military conflicts).

Due to the obligations included into their public service remit Deutsche Welle and Belsat are more inclined to promulgate European integration than BBC. For DW Europe seems to be one of the most important regions and a relevant context of German foreign image policy. DW cooperates with Polish TVP on producing programs for Belsat about the European integration. Informing and educating about the EU is an essential objective for this channel. It should attract Belarusians to the concept of European integration and European idea of democratic rule. 
For bigger European countries with languages which serve as languages of wider communication the inclusion of international broadcasting into public diplomacy is evident and natural. For smaller countries such as Poland - it has not gained such an importance yet due to limited sources that can be invested in such a tool of foreign policy.

All three broadcasters are also involved in country branding as they shape the image of the countries in direct way, presenting the culture and promoting languages. Indirectly, they promote the country by attracting attention and engaging the audiences into long-term relations. Their success - as in the British case - adds new value to the assets of soft power. Trust won by an international broadcaster pays off at the time of crisis.

\section{References}

Arquilla, J., Ronfeldt, D. (1999), The Emergence of Noopolitik. Toward an American Information Strategy, Santa Monica, RAND, available at: www.rand.org/pubs/monograph_reports/MR1033/, accessed: July 31, 2009.

Auswärtige Kulturpolitik - Konzeption 2000, available at: www.auswaertiges-amt.de/DE/ ArchivArtikel/Kultur, accessed: November 10, 2011.

Bahrke, J. (2010), “Auslandsrundfunk als strategisches Mittel europäischer Public Diplomacy im Nahen Osten", in: J. Tenscher, H. Viehrig, (eds), Politische Kommunikation in internationalen Beziehungen, LIT, Berlin, 191-214.

Cull, N. (2009), Lessons from the Past. CPD Perspectives on Public Diplomacy, Los Angeles: Figureaoa Press.

Denton, R. E, Jr., Woodward, G. C. (1990), Political Communication in America, New York: Greenwood Publishing Group.

Deutsche Welle Gesetz (2005), “Gesetz über eine Rundfunkanstalt des Bundesrechts”, ARD Jahrbuch 2005.

Dyke, G. (2003), Speech of the BBC Director General given at the University of London Goldsmiths College Journalism Symposium, 24 April, available at: http:/ / www.bbc.co.uk/ pressoffice/speeches/stories/dyke_journalism.shtml, accessed: March 24, 2013.

Fisher, A., Lucas, S. (eds) (2011), Trials of Engagement. The Future of US Public Diplomacy, Leiden: Martinus Nijhoff Publishers.

Horrocks, P. (2012), Delivering International News - How the BBC Has Increased Market Reach in the Middle East Region. Speech at the Saudi Broadcasting Forum in Riyadh on 29.09.2012, available at: www.bbc.co.uk/mediacentre/speeches, accessed: February 13, 2013.

O'Keeffe, A., Oliver, A. (2010), International Broadcasting and its Contribution to Public Diplomacy. Lowy Institute Papers and Reports, 9, September, available at: http://www.lowyinstitute.org/ publications/international-broadcasting-and-its-contribution-public-diplomacy, accessed: February 11, 2013.

Kierunki promocji Polski do 2015 [Directions of Polish Promotion till 2015] (2009), Document accepted by the Council of Polish Promotion. 
Leonard, M., Stead, C., Smewing, C. (2002), Public Diplomacy, London: The Foreign Policy Centre.

Meyen, M., Scheu, A. (2011), “The Role of External Broadcasting in a Closed Political system: A Case Study of the German Post-War States", Global Media and Communication 7(2), 115-128.

Michalek, Ch. (2009), Die Deutsche Welle im Rahmen von Public Diplomacy. Journalistisches Selbstverständnis und politischer Auftrag des deutschen Auslandrundfunks, AVM, München.

Nye, J. (2004), Soft Power. The Means to Success in World Politics, New York, Public Affairs.

Ociepka, B. (2013), “Nadawanie za granicę jako narzędzie dyplomacji publicznej w warunkach komunikowania globalnego" [International Broadcasting as a Tool of Public Diplomacy in the Era of Global Communication], in: J. Adamowski, A. Jaskiernia (eds), Systemy medialne w XXI wieku [Media Systems in the $21^{\text {st }}$ Century], Warszawa: Aspra, 83-98.

Ponad potowa posiadaczy anten satelitarnych oglada Bietsat [More Than Half of Satellite Dishes' Owners Watch Belsat], available at: http:// belsat.eu/pl/aktualności, accessed: September 6, 2012.

Porozumienie pomiędzy Ministerstwem Spraw Zagranicznych a TVP SA (2007) [Agreement between the MFA and TVPSA].

Price, M. E. (2003), "Public Diplomacy and Transformation of International Broadcasting”, Comparative Media Law Journal 1, 71-91.

Review of Public Diplomacy (2005). Copy of Letter from Sir Andrew Burns, BBC International Governor, to Lord Carter of Coles, available at: www.bbc.co.uk/pressoffice/ pressreleases/storie/2005/12_december/15/carter.shtml, accessed: June 12, 2013.

Schneider, C. (2004), "Culture Communicates: US Diplomacy That Works”, Discussion Papers on Diplomacy, Clingendael, 94.

Taylor, P. M. (2008), “Public Diplomacy and Strategic Communication”, in: N. Snow, P. M. Taylor (eds), Handbook of Public Diplomacy, London: Routledge.

Taylor, P. M. (2011), “Public Diplomacy on Trial?”, in: A. Fischer, S. Lucas (eds), Trials of Engagement. The Future of US Public Diplomacy, Leiden: Martinus Nijhoff Publishers.

Thompson, M. (2010), Nation speaking peace unto nation: the BBC global mission. Speech by the BBC Director General, available at: http:/ / www.bbc.co.uk/pressoffice/speeches/ stories/thompson_chatham.shtml, accessed: February 12, 2013.

UNESCO Interactive Atlas of the World's Languages in Danger (2013), available at: www.unesco.org/culture/languages-atlas/, accessed: June 12, 2013.

Unterrichtung durch die Deutsche Welle (2009), Deutscher Bundestag 16. Wahlperiode. Drucksache 16/11836.

Zaharna, R. S. (2007), “The Soft Power Differential: Network Communication and Mass Communication in Public Diplomacy", The Hague Journal of Diplomacy 2(3), 213-228.

Zierkalo-Info (2011), Sociologiczeskije i markietingowyje issliedowanija. Monitoring TV Belsat na Białorusi, Minsk, Document received from Belsat Office in Warsaw. 

Sandrine Roginsky

Catholic University of Louvain, Belgium

\section{Social Networking Sites: An Innovative Communication on Europe? \\ Analysis in the European Parliament, the European Commission, and the European Council}

\section{Introduction}

The lack of European Union (EU) legitimacy is often viewed, at least partly, as a communication deficit (Meyer, 1999; Andersen \& McLeod, 2004; de Vreese, Banducci, Semetko \& Boomgaarden, 2006; Spanier, 2012). Spanier (2012) defines the EU's communication deficit as "the apparent impossibility for the EU of communicating with its citizens". Lilleker \& Koc-Michalska (2011) state that both "the European Commission (EC) and European Parliament (EP) are keen to reduce the democratic deficit which is at the heart of critiques of politics at the European level." Meyer (1999) highlights the role of political communication in legitimating governance. Michailidou (2008:348) argues that "for the EU institutions a first step towards democratic legitimation is to establish public dialogue between the EU decision-makers and the public, with the latter's feedback incorporated in the decision-making process." Amongst the communication tools mobilized by the European institutions, Michailidou (2008:348) believes that the "Internet offers a viable alternative to an offline, more conventional media-regulated communicative platform."

The Internet has indeed been recognized as offering new means of political communication in democratic societies and extensive research has been conducted on the democratic potential of the Internet (Chadwick, 2006; Coleman, 2004; 2005; Coleman \& Blumler, 2009). Blumler and Coleman (2010:147) note that "with the emergence and evolution of the Internet, in its many shapes and guises, there has been a range of hopes and speculations about its redemptive potential." At the European level, this belief is even stronger. Lilleker and Koc-Michalska (2011) emphasize the potential the Internet offers for legitimizing the European institutions.

This article proposes to assess whether new political communicative spaces are emerging in the European Union as a result of the use of internet, and more specifically social networking sites (SNS), by political actors and civil servants within European institutions. What are the consequences for European policy makers and what is the impact on European political communication? The aim of this chapter is to present the features of EU communication on SNS and to examine whether the European media ecology has been transformed by social networking sites, in partic- 
ular the EU media relations. In order to identify, describe and analyze the main characteristics of EU digital communication, the article focuses on the three main European institutions (the European Commission, the European Parliament and the European Council). The research investigates whether SNS make it possible, or not, to overcome the communication deficit of the EU. First, the paper gives an overview of the place of SNS within institutions, second it investigates the type of communication of European institutions on SNS. After focusing on civil servants and political actors in the European Commission and Council, the presentation turns to Members of the European Parliament (MEPs) for eventually highlighting the situation of the "Brussels bubble"1 as a whole.

The paper adopts a multi-disciplinary approach that encompasses theories from political science, linguistic, sociology and communication studies. Its focus is on contexts, actors and practices, because "it is people who conduct European processes" (Adler-Nissen, in Busby 2011). This approach justifies the proposed research methodology: participant observation, interviews and discursive analysis. As a parliamentary assistant in the European Parliament between 2009 and 2012, it was possible for me to develop a deeper exploration of the institutional and political context and to understand better the relationship between people's practices and their context. Following this ethnographic fieldwork, a number of interviews were conducted in 2012 with civil servants, staff and politicians in the three institutions. The objective was to muster a very heterogeneous corpus which extends across discourses on SNS as well as discourses about SNS. Official and internal documents of institutions, texts emanating from SNS as well as interviews actors were incorporated into the corpus.

Theoretically, this paper is a continuation of Oger and Ollivier-Yaniv's research, whose work is at the crossroad of interpretive sociology and discursive analysis. "This rapprochement was initially suggested by problems of research emanating on the one hand from the sociology of political and public institutions and according to an important place to actors' discourse, and on the other hand from institutional discourse analysis" (Oger \& Ollivier Yaniv, 2013). Such an approach brings actors and agencies into the study of the EU communication, focusing on meaning, understanding and interpretation. The objective of this research is to appreciate the logic of practices and actors' understandings of the EU communication on SNS in order to assess whether the EU communication on SNS is innovative.

\section{Communicating Europe: the growing place of the Internet and social network sites}

"Commission staff are increasingly called upon to communicate with the general public and stakeholders via a wide variety of channels. One recent development is

1 The Brussels bubble refers to the working settings inside and outside the European institutions. 
that social media (...) are growing more popular for people-to-people communication." This is how "the guidelines to all staff on the use of social media" produced by the European Commission are introduced. ${ }^{2}$ On the side of the European Parliament, the assessment is similar: its strategic plan of communication 2011-2014 mentions: "Parliament's presence on social media platforms offers a unique, cost-efficient opportunity for interactivity with citizens." ${ }^{3}$

Furthermore in a resolution entitled "On journalism and new media - creating a public sphere in Europe," supported by a majority of Members of the EP, the EP believes that "social media are particularly adequate for communication. (...) One must be where the conversation takes place i.e. Facebook, Twitter and other online social networks." 4 There is no similar document for the European Council. In this institution, communication is viewed as "a service to specific users," 5 i.e. journalists and bloggers, European and national civil servants, researchers and students. However the three institutions are active on Twitter and Facebook. As recalled by Podkalicka and Shore (2010:100), the EU "has been particularly keen to mobilize online technologies, including popular social network sites."

Digital social networks appear to offer its users a tool for expression which is both personalized and institutionalized, and therefore could fit perfectly in the communication apparatus of European institutions. ${ }^{6}$ Moss and Coleman consider three communicative characteristics of the blogs which all relate to impression management (Goffman, 1959): "politicians attempts to seem like ordinary people" (Moss \& Coleman, 2008:9), they develop relationships with citizens which are live, spontaneous and direct, they are both "conversing with and listening to the public" (Moss \& Coleman, 2008:9). All those three characteristics are today attributed to SNS by academics. ${ }^{7}$ Therefore there is an injunction for actors, both in the EC and the EP but also - to a lesser extent - in the European Council, to use web 2.0 tools in order to interact with citizens and to create space for moments of deliberative democracy. "The use of social networking platforms, it is argued, can play an essential role in politics broadly by attaching visitors to these online presences to

\footnotetext{
2 European Commission, Social Media Guidelines for all staff, http:/ / ec.europa.eu/ipg/docs/ guidelines_social_media_en.pdf.

3 European Parliament, "Action plan for the implementation of the Parliament's updated communication strategy 2011-2014".

4 Report on journalism and new media - creating a public sphere in Europe, 2010/2015(INI), 2/7/2010.

5 Interview 1.

6 The Communication officer of a Commissioner explains that on SNS' accounts, the Commissioner writes both "in her capacity as a commissioner and as a person" (Interview 8).

7 About Twitter, for instance, Jackson and Lilleker write: "the most popular use of Twitter is for self-promotion (...)” (2011:87). “Through the promotion of self, MPs encourage voters to develop an empathy with the politician as an ordinary human being. (...) That tools such as Twitter offer an easy, convenient and controllable way of communicating such personal information" (2011:90). See also Castells (2001), The Internet Galaxy: Reflections on the Internet, Business and Society, Oxford: Oxford University Press.
} 
the host and their political campaign" (Lilleker \& Koc-Michalska, 2011). ${ }^{8}$ Hence, Lilleker and Koc-Michalska call for a greater use of SNS. Boyd and Elison (2007) define SNS as "web-based services that allow individuals to (1) construct a public or semi-public profile within a bounded system, (2) articulate a list of other users with whom they share a connection, and (3) view and traverse their list of connections and those made by others within the system. The nature and nomenclature of these connections may vary from site to site." This definition focuses on SNS 9 such as Facebook. In this paper, the two social network sites that are the most commonly used by the EU are examined: Facebook but also Twitter. Twitter is "a microblogging site which allows users to deliver statements, thoughts and links in 140 characters to followers as well as a wider Internet audience" (Jackson \& Lilleker, 2011).

Counting the different accounts of the institutions on Twitter and Facebook is not an easy task, especially as regards to the European Commission. In April 2012, on Twitter there were one main institutional account (@EU_Commission), 20 DGs Twitter accounts, 16 personal accounts of Commissioners, 16 personal accounts of Commissioners' spokespersons, three personal accounts for spokespersons of the entire institution, plus a number of accounts for specific projects or services. On top of that, not included in the research, there are 27 accounts of national offices of the Commission as well as the official offices outside the EU. The communication of the EP as an institution is less diffused, with one main Twitter account in English, different Twitter accounts for each official language of the EU as well as accounts of parliamentary committees and the press media team. ${ }^{10}$ But in this institution, there are also $766 \mathrm{MEPs}^{11}$, politicians directly elected by citizens, amongst whom a majority is now using SNS according to different recent studies. ${ }^{12}$ Besides, the institution has developed a specific platform entirely dedicated to political actors of the EP, which is called EP Newshub and displays items that those actors have published on other platforms, such as Twitter and Facebook. ${ }^{13}$

\footnotetext{
8 See this press release by European People's Party group in the European Parliament: "Web $2.0^{\prime}$ tools are a constitutive element of our contemporary societies and are crucial to enhance direct contact with EU citizens. Promoting and enhancing the use by MEPs of 2.0 tools contributes to getting Europe closer to citizens on a daily basis.", October 1, 2010.

${ }^{9}$ In this paper, social media, social networking sites and social network sites are used interchangeably.

10 The different platforms are presented on the EP website: http://www.europarl.europa.eu/aboutparliament/en/00fd7b595a/Social-media.html.

11 At the time of writing, there are 766 MEPs, but there will be 754 MEPs elected at the 2014 elections.

12 Studies conducted by various research and public affairs consultancies, such as "EU Social Media Usage: New trends, new opportunities" in May 2013 (http:/ / www.digitalpulse.eu/ EUDigitalPulse_2012.pdf); “Fleishman-Hillard's 2nd European Parliament Digital Trends study" in December 2011 (http:/ / www.epdigitaltrends.eu/) and "New MEPs survey: attitude towards information and communications tools" in September 2009 (http:/ / www.webershandwick.eu/inline-docs/inline-survey.pdf).

13 http://www.europarl.europa.eu/the-secretary-general/en/activities/recent_activities/ articles/articles-2012/articles-2012-july/articles-2012-july-1.html.
} 


\section{Communication of European institutions on SNS: political, institutional, or personal communication?}

Ollivier-Yaniv and Oger (2006) define institutional discourses as those which are officially produced by an individual or collective actor who has a legally registered position, whether he or she is a civil servant or a political representative. In other words, the institution circumscribes the status of the addressers, ${ }^{14}$ the types of contents that are said or not, etc. As Maingueneau (2002) explains, "the speakers enter a pre-established frame which, generally, they do not modify". On the contrary, SNS seem to alter and modify this "communication contract" (Charaudeau, 2002). Charaudeau defines communication contract as follows: a speaker and an addressee are bound by a reciprocal recognition contract that allows them to understand each other. This contract has the function of constraining the operating procedures of production and interpretation of the communication act, while at the same time allowing the participants to co-construct the meaning (Charaudeau, 2002). However, SNS aggregate and mix together, in a single space, not only the different status of the addressers (e.g. a Commissioner may talk as a spokesperson for the institution and he may talk as a national politician) but also the addressers who have different statuses (i.e. a Commissioner and a spokesperson). In other words, the status of the issuer is not perfectly clear and is fluctuating: a representative of the institution for some messages, a representative of him/herself for others. Statuses of addressers vary, which impact upon communication itself, both in terms of types and contents. Denton and Woodward (1990, in McNair, 2011:3) characterize political communication in terms of the intentions of its senders to influence the political environment. As they put it: "the crucial factor that makes communication political is not the source of a message but its content and purpose."15 Political communication is argumentative. "It is, first and foremost, politics. It is about all the communication efforts by those addressers who try to make people adhere to public perceptions that will orient their preferences" (Gerstlé, 2004:6).

Therefore the question here is whether communication of European institutions on SNS is political or not. If not political, communication on SNS can be institutional or personal. Pasquier (2011) defines institutional communication as a form of communication focusing on promoting institutions and public organizations. "It is not about emphasizing activities but the organization itself", as "organizations need to position themselves and to build a positive image which makes it possible to achieve the objectives" (2011:77-78). According to him, institutional communication is a form of public communication. It is mainly focused on informing. A person-

\footnotetext{
14 I use the notion of «addresser» as it entails that speech participants are construed as roles. In this respect, any statement is the result of enunciation and the elements intervening in this enunciation or communicative act are the addresser, the addressee, the content and the concrete moment and place which make up the situation of enunciation.

15 The research highlights that communication of European politicians often follows editorial rules that usually apply to press writing, providing more and more factual analysis.
} 
alized form of communication, on the other hand, relies on an expressive form of communication (Breton \& Proulx, 2002). If we go back to Jakobson's functions of language, this type of message "aims at a direct expression of the speaker's attitude toward what he is speaking about. It tends to produce an impression of a certain emotion, whether true or feigned" (Jakobson, 1960). On Facebook, communication of EU institutions is mostly informative and explanatory. On Twitter, the actors in charge of communication who have been interviewed point out that there are:

"two types of Tweets: [firstly] political tweets, [which are] more interesting [and] more personal, in order to communicate on things that we cannot find in press releases, and [secondly] tweets to push information, that are more institutional tweets, to send people to the website."16

The institutional messages follow "the lines to take that are disseminated among everybody, defensive points that are disseminated among cabinets, commissioners, spokespeople, so that there is a certain degree of coherence." 17 The discursive analysis conducted in this research shows that these types of message are the most frequent ones on Twitter, on all the different accounts, in each institution. But the specificity of SNS is the possibility to juxtapose different types of messages - as illustrated by the example below. On one particular day, ten messages are published on the European Commission and European Parliament's Twitter account that address various topics and, more importantly, swing between an informative and political register - following the definition that Gerstlé (2004) gives of political communication. According to him indeed, messages that encourage the follower to give his or her view are a form of political communication. In the example below, we find three political messages on the European Commission's account. The EP also uses this type of editorial messages, mostly on Facebook.

However, those messages seem to serve communication purposes only: it is not clear whether and how the feedback of followers on SNS is taken into account by the institution.

These messages are what Ollivier-Yaniv and Oger (2006) call "institutionalizing discourses" that can be carried out by any institutional addresser, and can be easily understood, but are removed from the specific contextual circumstances of the enunciation. These institutional discourses are updated on a permanent basis and are therefore always of-the-moment. Thus, even on contentious topic, such as ACTA, 18 the communication of the European Parliament is mainly descriptive and neutral: the account merely describes what is happening in the institution.

16 Interview 2.

17 Interview 3.

18 ACTA - Anti-counterfeiting Trade Agreement - is an international trade agreement dealing with intellectual piracy around the word. ACTA is no longer a planned treaty for the EU as the European Parliament voted against. 


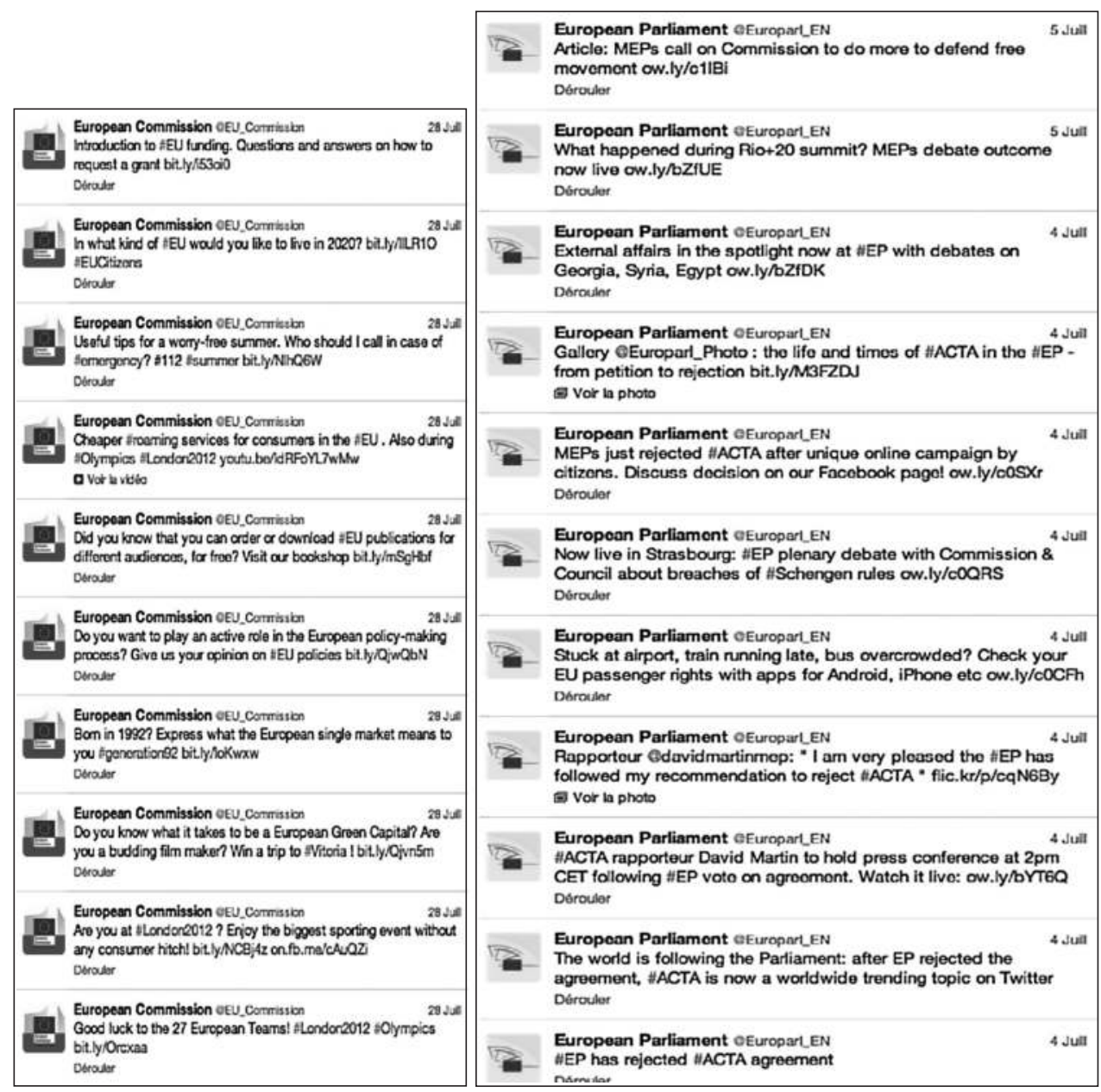

Indeed, "the editorial line must respect political neutrality and share the platform equitably across the different political opinions expressed by Members of the European Parliament."19 Such a process consists of "smoothing of political content" through two procedures that Oger and Ollivier-Yaniv (2006) have highlighted: firstly the change of timing and secondly the deletion of partisan politics. The account of the President of the Commission is the best illustration: it was first called "European Commission", then the name changed to "EC_live" and it is now "BarrosoEU". This account is particularly interesting:

"Throughout 2011 there was an awareness that this catch-all account would not do the trick for political communication anymore. That's when we separated it and kept the EU_Commission for more general collegial communication, and factual information about the Commission as the

19 Interview 4. 
central Twitter account for the Commission. But then [we] established in September 2011 the EC_live Twitter account. And the EC-Live Twitter account has also the image of President Barroso which indicates already that it's really something more presidential. So this is now about the political messages coming from the President." 20

However, building on the definition of Gerstlé (2004) and Pasquier (2011) of political and institutional communication, those messages appear to be part of the second and not the first category following a process of "smoothing of political content" as described above. ${ }^{21}$ Such statements tend to be decontextualized: they extend over the long time and are of universal capacity. Oger and Ollivier-Yaniv argue that this type of timeless enunciation characterizes the institution rather than its representatives. In other words, messages survive the addresser who produces them. However, a comparative analysis of the Twitter accounts of the President and the Commissioners of the European Commission adds a nuance to what has been said. Some particular actors on rare occasions circumvent the rules of enunciation of the institutions. This is the case of Commissioner Andor who uses his Twitter account to sometimes broadcast political views different from the one of the institution, using regularly external hyperlinks to newspapers to make outside voices heard.

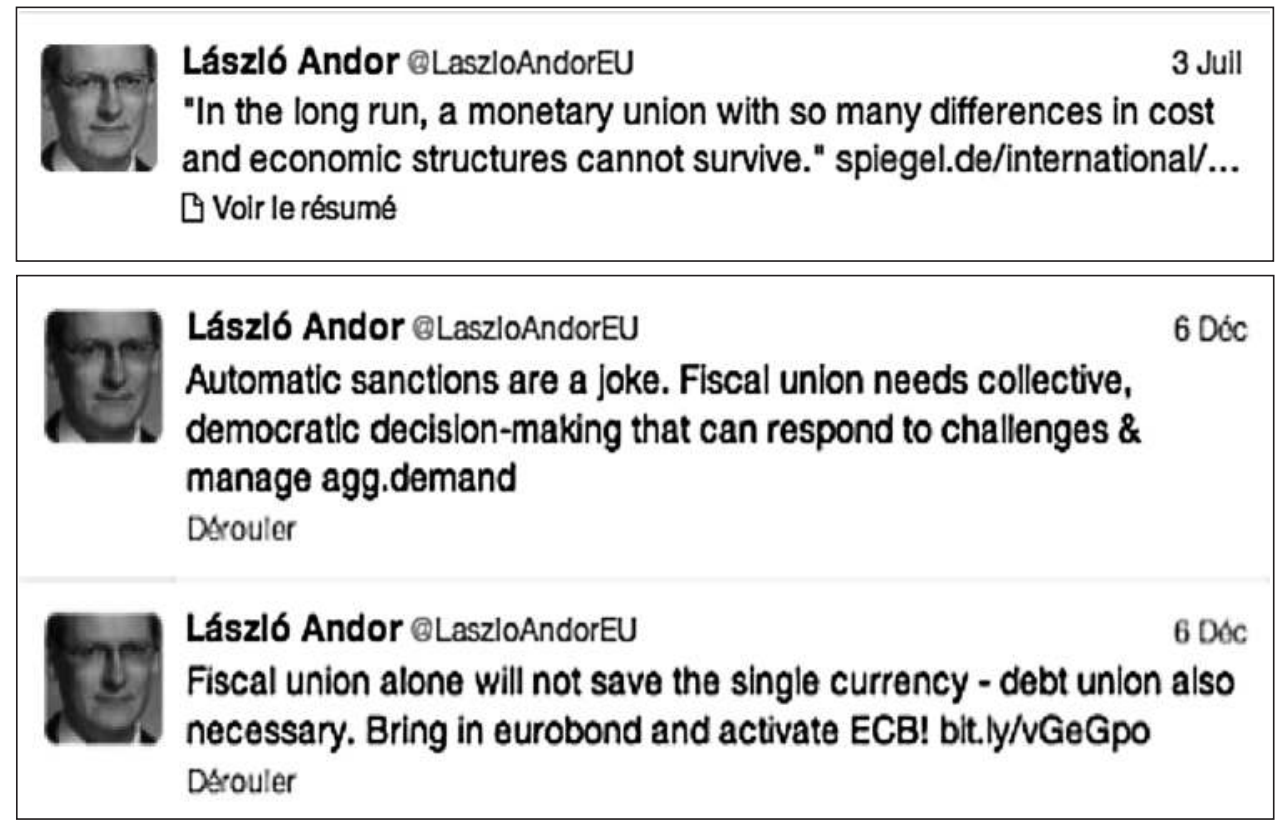

Another interesting example, very rare if not unique, is the insight into an internal dispute given by another Commissioner. The meeting of the "College of Com-

20 Interview 3.

21 Pictures also participate in the smoothing of communication. 
missioners" are held in camera, it is therefore even more surprising to read such a comment on a social networking site.

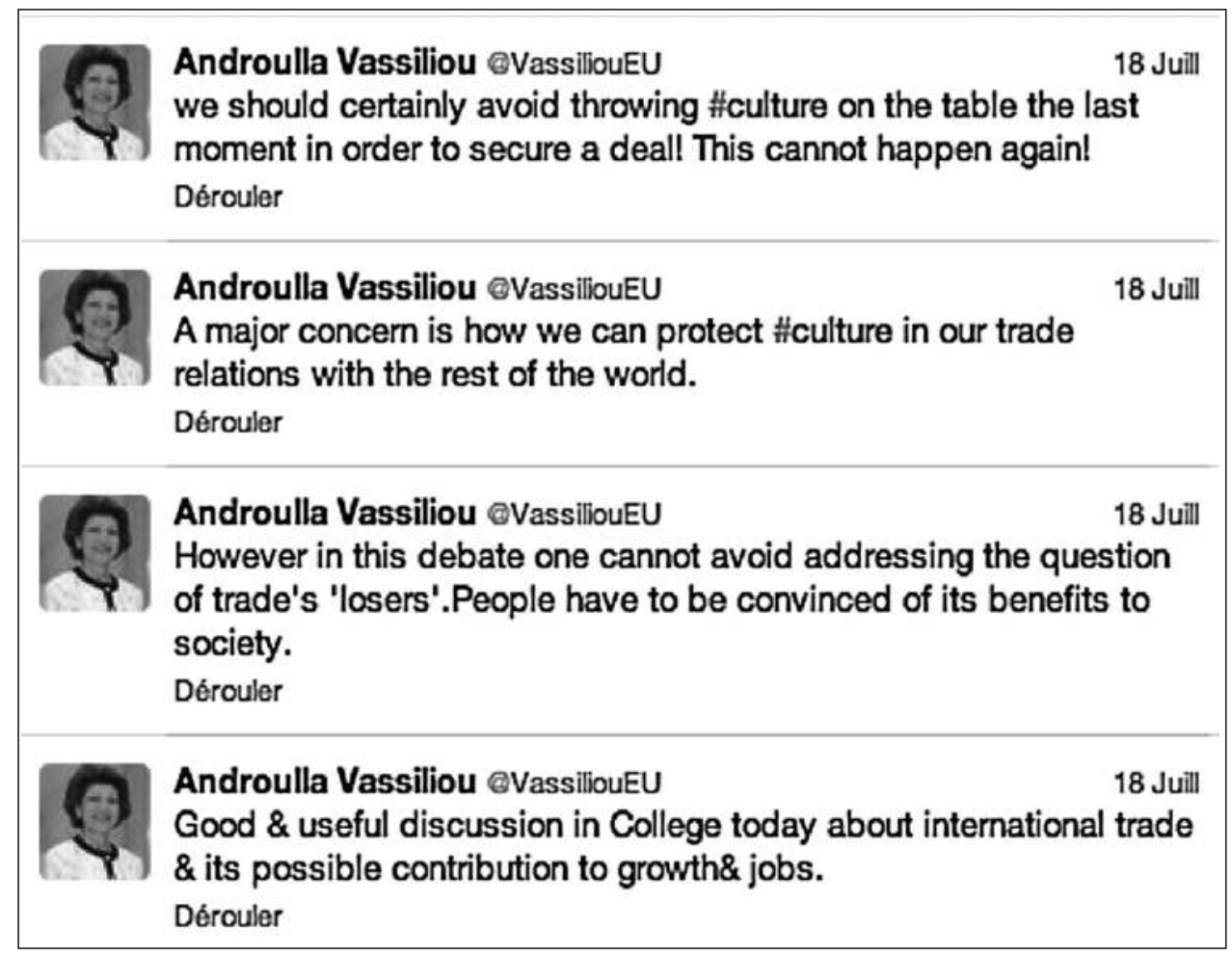

As expected on SNS, some personal messages are diluted amongst publications.

Cecilia Malmström @MalmstromEU

Quite deserted in Berlaymont now. Guess everybody has gone egg hunting. Seems as a good idea/CM

Dérouler

Overall, if SNS mix together different genres of communication (informative/institutional, argumentative/political and expressive/personal), there are a great deal of institutional discourses (i.e authorized discourses) and, more rarely, political discourses or personal stories. Even if theoretically SNS allow the communication to be more personalized, the institutional constraints of the enunciation minimize this process of personalization. This is also the case in the European Council: "we don't do politics, only institutional communication." 22 Oger and Ollivier-Yaniv

22 Interview 1. 
(2006) have noticed that institutional discourses are most of the time explicative, sometimes disjunctive, but very rarely argumentative. Furthermore, account profiles bring further confusion into communication: in the European Commission and European Council, the name of officials usually includes "EU". By tying the name of the person and the institution together, it makes it difficult to distinguish one to the other. Such a procedure participates to the process of decontextualisation and institutionalization of communication. Even though actors interviewed for the research all argue that "you need to be as political as possible," 23 "consensus is boring, people feel there is nothing at stake" 24 and "consensual and authorized messages are not good communication. It is better to have a political opinion," 25 the messages they produce are mostly consensual and institutionalized: "they are a mix. I would say $30 \%$ political communication, $70 \%$ institutional communication." 26 As pointed out by Aldrin and Utard (2008), "communication has always been the subject of accommodation between the competing logics of the institutions and the political constraints of compromise." On top of that, it is important to keep in mind that computed-mediated discourse is also shaped "by the technological features of computer-mediated communication systems" (Herring, 2004), such as SNS.

\section{Communication reflects organizations}

In each institution, constraints borne by official and prescriptive institutional enunciation impact on the discourse produced by actors on SNS. In the European Commission, the activity of producing speech on SNS is explicitly and officially constrained by contradictory injunctions: the injunction to be on SNS, which is perceived by the actors as being a personalized and an interactive media, while respecting a series of rules that go against these characteristics, such as objectivity, impartiality, discretion, circumspection. ${ }^{27}$ In other words, staff and members must write freely under constraint. Validation processes highlight the type of constraints that some civil servants have to follow. In the European Commission, "within DG, the validation process is heavy. It makes interaction difficult." 28 In a very decentralized organization, this means that the validation process is repeated in each DG. "In the European Parliament, it is more centralized. In the Commission, there is a DG COMM but there is a DG COMM in each DG. Here, it is smaller, it's easier." 29

However, in the European Parliament too, there is a validation process: the editorial content is discussed and decided once the week by the social media team, and usually validated by the spokesperson of the EP. In the European Council, "there is

23 Interview 5.

24 Interview 2.

25 Interview 2.

26 Ibidem.

27 European Commission, Social Media Guidelines for all staff, op. cit.

28 Interview 2.

29 Interview 4. 
a strong legal tradition and resistance on the part of administration" 30 and a small marge of maneuver with regards to communication on SNS. If SNS are supposed to enable a form of direct dialogue and interactivity, some addressers are nevertheless constrained to keep some reserve and must go through a validation process before publishing a message. "It is difficult to take it upon oneself to write, it is not our rule to perform in the interface, to be in direct contact, to reply." 31 Nevertheless, this assessment is somewhat mitigated when looking at specific civil servants, such as spokespersons and other top officials of the institutions. According to Georgakakis (2010:117), "there is a growing gap between people who have invested in the EU and invested by the EU as their political representatives." In the European Commission, he argues that Commissioners are becoming more and more "professionalized politicians" who are only passing through the Commission whilst civil servants are permanent staff of the EU and have a central role. "Members and civil servants in the European Commission have never been so distant from each other" (2012:44) and civil servants have even more autonomy than before. Communication on SNS is both an illustration of such a situation and a tool to gain autonomy. The Communications Officer of a Commissioner regrets that "too many tweets come from the services. There is a lack of coherence." 32

Georgakakis (2012:75) believes that "the problem of the Commission comes more from the capacity of its staff to embody politics rather than its decline as organization." His observation on the functioning of the organization brings some light on the specific question of communication. Such communication carries the collective constraints which impact on the enunciation of the institution. Communication is generally neutralized and consensual: conflicts and debates are absent. To put it simply, Commissioners on SNS follow similar rules and display clear affinity with administrative representatives when it comes to publishing messages. Even though "European Commissioners nowadays clearly embody the political function within the European Commission" (Georgakakis, 2010:128), it does not seem to be necessarily reflected on SNS where civil servants appear to also carry this function.

Digital platforms provide civil servants, and in particular spokespersons, with a new room for expression. If originally the spokesperson function and purpose was to communicate with journalists, with SNS the spokesperson can now communicate directly to a wider audience. The spokesperson of the European Parliament explains: "this is the first time that we can use tools that put us directly in touch with people, with 'the man in the street', without going through intermediaries, whether it is journalists or others." 33 SNS redefine the concept of "spokesperson" in expanding it beyond the official function.

Bourdieu (2004) talks about "authorized speech": "in contrast to individual speech, shouts or protests, the speech of the spokesperson is an authorized speech

\footnotetext{
30 Interview 1.

31 Interview 4.

32 Interview 2.

33 Interview 6.
} 
which owes its authority to the fact that the person who speaks it draws his authority from the group which authorizes him to speak in its name. When the spokesperson speaks, it is a group that speaks through him, but one that exists as a group through that speech and its speaker" (Bourdieu, 2004:41). Marcoccia (2004) argues that a spokesperson is both a representative and an intermediary. In a platform in which political representatives themselves are present and while those tools are praised for improving the "direct and regular contact" (Jackson \& Lilleker, 2011:90) between politicians and the general public, SNS bring together those two types of representatives: political representatives (politicians) and institutional representatives (civil servants, such as spokespersons). While spokespersons' public discourses are usually constrained by the organization and therefore depersonalized, we find this is not necessarily the case on Twitter where Commissioners' spokespersons or European Commission's spokespersons sometimes talk on their own names.

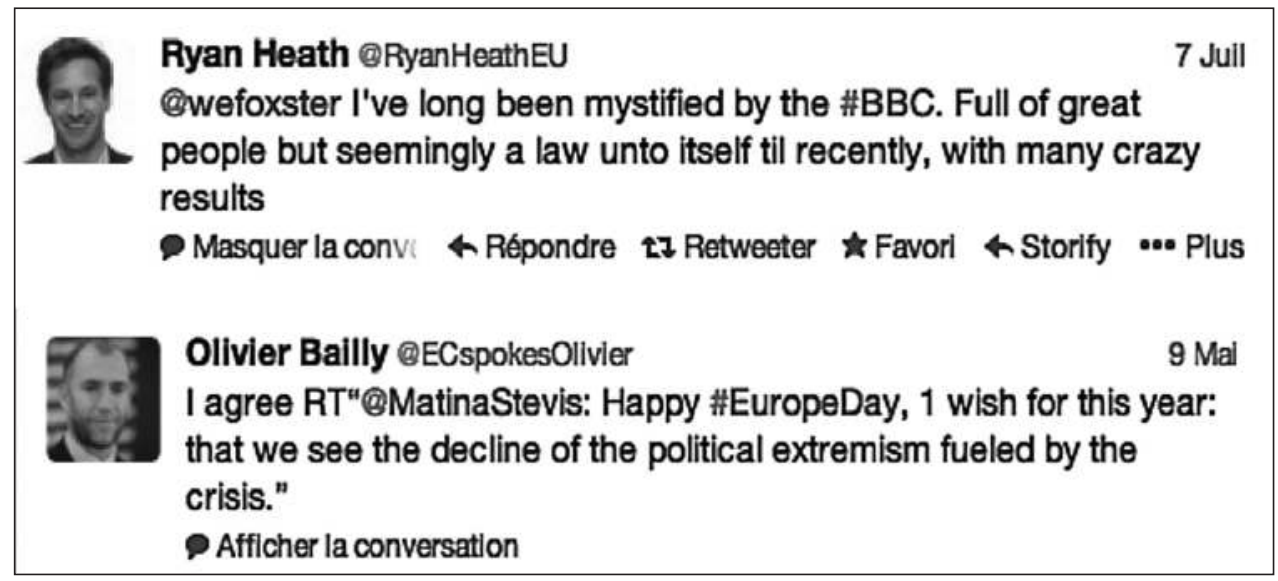

The European Parliament towards a more political communication?

In the European Parliament as well, administrative and political officials communicate in parallel. The Parliament as an institution has been using SNS for a few years emphasizing everyday life issues and proximity to people especially on Facebook, not without success. ${ }^{34}$

Civil servants in the European Parliament in charge of communication on social media believe that they have more space for expression than their colleagues in the European Commission and Council:

34 The European Parliament is one of the top public institutions worldwide for the number of Facebook fans. 

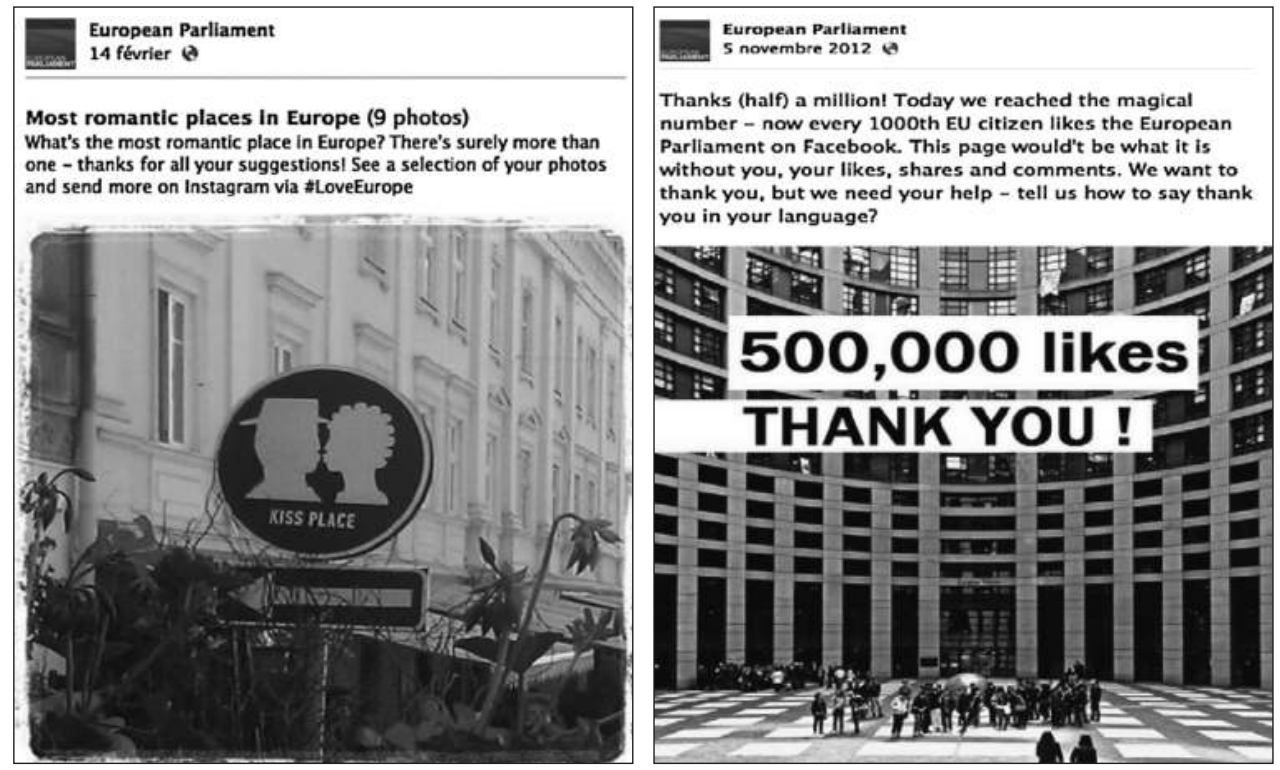

Sources: EP Facebook account.

"The European Parliament had the tremendous benefit that it can express political opinions, it can relay the controversies amongst MEPs. In the European Council, we cannot even defend the position of a Member State." 35

"For us, it is easier than for the Commission. There is a need for drama, for political conflict. It is more interesting. Compromise is good if there is conflict beforehand. This legislative term is more interesting. Since Lisbon, ${ }^{36}$ it is more interesting. Compromise should not be made behind close doors. Before, it was sometimes the case." 37

However, an analysis of the Facebook and Twitter accounts of the institution shows that political conflicts in the European Parliament are not really brought forward. As highlighted before, communication is consensual, giving essentially the results of votes on Facebook and Twitter accounts and creating an illusion of harmony in the EP. As an official in the WebComm Unit puts it: "we are in an institution, we have to stay within scope, we cannot be rock roll all the time." 38

Parliament voted "no" to ACTA. It means this agreement will not enter into force in the EU. More details about the vote @ http://epfacebook.eu/wa

Source: EP Facebook account, 4 July 2012.

35 Interview 1.

36 Interview 4.

37 The Lisbon Treaty further empowered the EP and expanded its competence into new legislative areas since 1 December 2009.

38 Interview 4. 


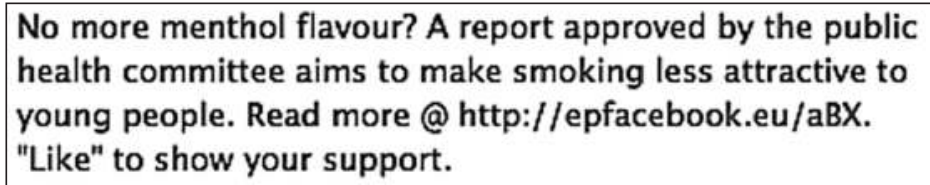

Source: EP Facebook account, 11 July 2013.

Nevertheless, communication of the EP as an institution benefits from its members who, contrary to the European Commission and the European Council, are directly elected by the citizens to sit in the assembly. They bring political communication to the institution.

They both want to make Europe and its economy work, but in different
ways. Martin Callanan, the leader of the Conservatives and Reformists in
Parliament, believes that open markets, not government borrowing and
spending are needed to fix the economy, while Rebecca Harms, the leader
of the Greens in Parliament, thinks the politics of pure austerity proved to
be a failure and instead smart investments to boost the economy are
necessary to help countries such as Greece.
Do you agree? Disagree? Let them know! Join our chat next Tuesday @
15.00 CET to discuss your views with Callanan and Harms. They are not
only waiting for your questions, but also for comments and opinions! Don't
miss this unique opportunity to directly discuss with the leaders of two
important political groups in Parliament. To join click @
http://chat.epfacebook.eu/

Source: EP Facebook account, 5 July 2013.

The remit of the Members of the European Parliament when it comes to communication is indeed more clearly defined: MEPs communicate their personal views and opinions without any institution constraints, contrary to Commissioners. ${ }^{39}$ "It is not possible for Commissioners to express personal opinions, they are required to collegiality, to consensus." 40 As pointed it out before, Commissioners generally opt for institutional discourses rather than political opinions on SNS, their messages on SNS are usually much more consensual than MEPs' messages. Even though MEPs use SNS as a tool of impression management (Jackson \& Lilleker, 2011), the analysis highlights that additionally they view SNS as a way to spread political opinions. Even if messages are not necessarily about the EU as such but rather about themselves, a specific legislative issue or a political event, Beauvallet (2007:409) argues that "it would be the duty of each MEP to explain Europe, if not making it likeable,

39 Costa (2002) argues that MEPs enjoy considerable level of freedom as regards to their mandate, both in terms of priorities and experiences. They can act freely as interpreters and intermediaries of citizens' expectancies. Besides, because of the lack of interest of people in the European Parliament, their marge of maneuver is even bigger.

40 Interview 4. 
and to inform citizens." Therefore individual communication of MEPs would then contribute to the communication of the EU as a whole and supports its legitimacy. Besides, as in the other institutions, a significant proportion of messages published on SNS by MEPs are also informative, giving details about important votes or debates in the EP.

\section{The e-"Brussels bubble": a transformation of European media ecology?}

"The value of social media lies in their potential to connect with citizens, [to] listen and dialogue with them, and [to] access user groups that are less likely to be reached [through] traditional media." 41

"I am confident that SNS can change the image of the European Commission." 42

"Social media are the best and only way to give a good image for the Commission." 43

A significant proportion of officials that were interviewed highlight two main outcomes of using SNS to communicate, i.e. direct communication with "the man in the street" and impression management of EU institutions. However, the results of this research show that there are some discrepancies between this objective and the functioning of the organizations, especially the European Commission and the European Council. As highlighted by Michailidou (2007), it is still not always clear if it is the Commission and other institutions' view "that the Internet should be used to address a niche public, i.e. the European elites, more than it should be used to communicated with the general public". In the European Commission, "we need to get in touch with a specific audience, what we could call a niche-interests communication." 44 In the European Council,

"on SNS, we only target specific audiences that use this tool: journalists and bloggers, civil servants from other EU institutions, national civil servants in Members Stages, researchers and academics, students. (....) We do not try to over communicate, we do not try to seduce, we are not looking for more followers, we do not do advertising." 45

This is even more the case on Twitter, which is perceived by all the interviewees in the three institutions as a "more professional" SNS. "Twitter is useful to communicate on things that we don't find elsewhere. On Twitter, people are a bit more spe-

41 Answer given by Commissioner Reding to a Parliamentary Question on behalf of the European Commission: http://www.europarl.europa.eu/sides/getAllAnswers.do?reference $=\mathrm{E}-2011-004558 \&$ language $=\mathrm{EN}$.

42 Interview 8.

43 Interview 9.

44 Interview 7.

45 Interview 1. 
cialized, they know where to find the information;" 46; "On Twitter, there is over representation of politicians, organizations, journalists, people in official capacity...." 47

Arguably, EU communication on Twitter is expert driven. Therefore, the observation of Spanier: "the information addresses a few initiated persons rather than the average citizens" (Spanier 2010:85) should be expanded to SNS. The Brussels bubble refers to the working settings inside and outside the European institutions, "a multinational and multilingual space, an intense environment with a distinct rhythm of life, where people come and go often but which feels like a small village where everyone seems to know each other and news travel fast" (Busby, 2011). After monitoring the EU institutions on SNS (Facebook and Twitter), it has become evident that an e-Brussels bubble has emerged on Twitter and possibly, to a lesser degree, on Facebook. SNS, and in particular Twitter, serve more as a means of self-observation of those individuals involved in the Brussels bubble. Besides, the use of English as the main language of expression on the main institutional accounts of each EU organization is a complementary illustration of a certain closure of those networks.

However, if SNS do not seem to have fundamentally alter political communication, EU media relations have been transformed to some extent: SNS contribute to reshaping relationships with journalists. The relationship politicians maintain with traditional media is crucial in political communication (Blumler \& Gurevitch, 1995). SNS, mostly Twitter, are a supplementary tool to build up this relationships between representatives, both institutional and political, and journalists.

"We have quite a number of journalists of course, which is natural because they see us as spokespeople in the Commission and they are the ones asking the questions in the press room everyday, they're the one calling us also on the phone, but they follow us also on Twitter and more and more journalists are also on Twitter. They literally can see when they start Twitter account with 5, 6 followers and then they put you pretty soon among their people to follow as well, so they really recognize that the Commission has opened new communication channels here by social media, that it is important to stay tuned on that one as well." 48

Twitter is appreciated for its function of direct dialogue with journalists; this is particularly true between spokespersons and journalists, as illustrated with the example below: Koen Doens (@ECspokespersonKoen) is a spokesperson for the European Commission and Peter Spiegel (@SpiegelPeter) is the Brussels Bureau Chief for the Financial Times. On the left side, the print screen from Twitter shows a direct communication between both actors. On the right side, on top of those two actors, the dialogue also involves someone from the Lithuanian Presidency of the Council of the EU Communications team (@EU2013LTpress) and the Europe Editor of the

46 Interview 2.

47 Interview 3.

48 Ibidem. 
Guardian (@traynorbrussels). The dialogue shows some kind of acquaintance between this different types of actors. Baisnée (2007) talks about the complicity and social proximity between journalists and "political and administrative actors". SNS shed some light on those specific ties. In a way, they publicize private and interpersonal communication and contribute to render more transparent the mediatization process of the EU - at least to researchers if not the general public.

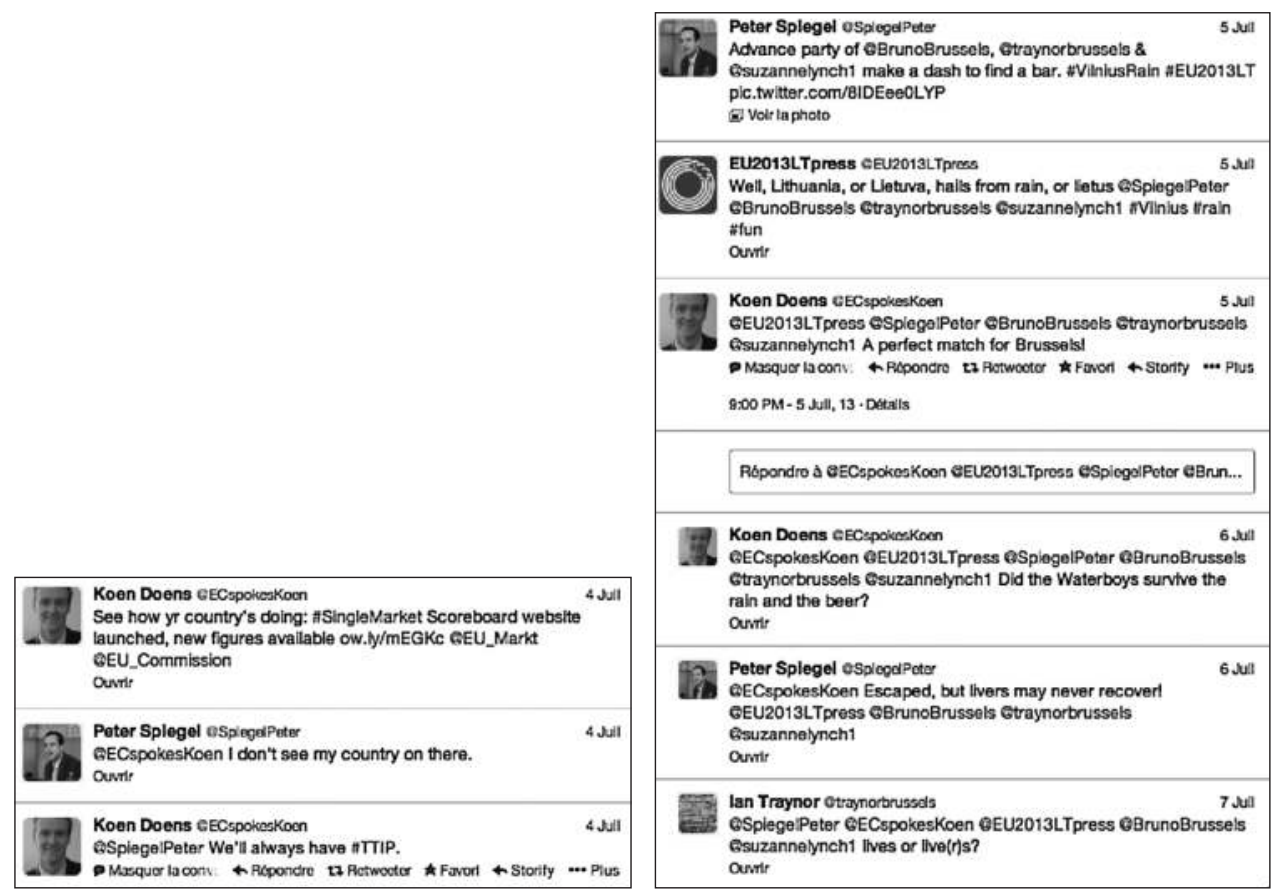

\section{Conclusions}

Traditionally, the Commission's discourse tends to depoliticize EU decisions in presenting them as the consensual result of a confrontation of expertise (Aldrin \& Dakowska, 2011). According to V. Schmidt (2006), the EU produces "policy without politics". Social networking-sites do not fundamentally alter communication of European actors, leaving the situation largely unchanged. Discourses on social networking-sites lead indeed to the blurring of politics and to a consensual form of communication. Communication on SNS is constrained by various variables, such as the functioning of institutions, the rules and relationships between actors but also the technical interfaces (Facebook and Twitter follow themselves a series of editorial rules).

Communication of the European institutions on Twitter and Facebook is therefore institutionalized and de-politicized, thereby suggesting that the innovation - if real - is limited to some specific attributes. Generally, SNS bring a form of confused 
innovation while maintaining the traditional functioning of the organizations. They provide a platform of expression to a multiplicity of actors with a multiplicity of statuses. In particular, SNS tend to give prominence to important actors such as spokespersons who might have been not as visible to a wider audience while obscuring some backstage key actors who nonetheless have a key role as communication and information managers. In other words, they lighten up the validation process for some actors while maintaining it for others. That said practices and understandings of SNS are not homogeneous amongst EU actors. On the contrary, this research highlights hybrid usages of social networking-sites. There are as many usages and practices as there are different types of actors (spokespersons, other mandated staff, editorial staff, commissioners, members of the European Parliament, assistants, etc.).

In such a context, there is no clear and common communication strategy, at least in the European Commission which is nonetheless responsible for the communication of the EU as a whole. In the European Parliament there is a clear attempt to use SNS to emphasize proximity and closeness to people. However, SNS do not really modify the communication of the European institutions, notably because "SNS add to without questioning the other information tools." 49 SNS are indeed often used as an intermediary to direct the follower to other source of information. "Social media platforms are being used to draw people's attention to relevant information on the Europa website. Hence the investment the Commission is making to continuously improve the Europa website." 50 The capacity of SNS to reduce the so-called communication deficit of the EU seems in this context limited. It remains to be seen whether MEPs, through a less institutional type of communication, are able to strengthen EU communication as a whole.

\section{List of interviews}

Interview 1: Civil servant in charge of digital communication, European Council, July 19, 2012.

Interview 2: Commissioners' Communication Officer, Cabinet of European Commissioner, July 11, 2012.

Interview 3: European Commission's Spokesperson, July 24, 2012.

Interview 4: Civil servant in charge of digital communication, WebComm Unit, European Parliament, July 9, 2012.

Interview 5: European Commissioner' Spokesperson, July 3, 2012.

Interview 6: Spokesperson of the European Parliament, August 30, 2012.

Interview 7: Civil Servant in charge of communication, DG REGI, July 18, 2012.

49 Interview 6.

50 Answer given by Commissioner Reading to a Parliamentary Question on behalf of the European Commission, op. cit. 
Interview 8: Commissioner's Communication and Press Officer, Cabinet of European Commissioner, July 13, 2012.

Interview 9: Contractual agent, Social Media Team of the European Commission, July 20, 2012.

\section{References}

Aldrin, P., Utard, J. M. (2008), The ambivalent politicization of European communication. Genesis of the controversies and institutional frictions surrounding the 2006 White Paper, GSPE Working Papers.

Aldrin, P., Dakowska, D. (2011), “Légitimer l’Europe sans Bruxelles? Un regard sur les petits entrepreneurs d'Europe, entre décentrement et recentrages", Politique européenne 34, 7-35.

Anderson, P. J., McLeod, A. (2004), “The Great non-Communicator? The Mass Communication Deficit of the European Parliament and its Press Directorate", Journal of Common Market Studies 42 (5), 897-917.

Baisnée, O. (2007), “En être ou pas. Les logiques de l'entre soi à Bruxelles”, Actes de la recherche en sciences sociales, 1-2, No. 166-167, 110-121.

Beauvallet, W. (2007), Profession: eurodéputé. Les élus français au Parlement européen et l'institutionnalisation d'une nouvelle figure politique et elective (1979-2004), Thèse de doctorat, Université Strasbourg 3.

Busby, A. (2011), "Bursting the Brussels Bubble": What can ethnography tell us about politics at the European Parliament?, UACES Student Forum 12 $2^{\text {th }}$ Annual Conference on the panel "Europe, Discourse and Institutions: Challenging the mainstream in European Studies II", University of Surrey.

Blumler, J. G., Coleman, S. (2010), "Political Communication in Freefall: The British Case - and Others?", The International Journal of Press/Politics, 15, 139-154.

Bourdieu, P. (2004), "The Mystery of the Ministry: From Particular Wills to the General Will”, Constellations, Vol. 11, No. 1, available at: http://istifhane.files.wordpress.com/2010/ 08/ bourdieu-the-mystery-of-the-ministry-from-particular-wills-to-the-general-will.pdf.

Boyd, D., Ellison, N. (2007), "Social Network Sites: Definition, History and Scholarship", Journal of Computer-Mediated Communication Vol. 13, No. 1, available at: http://jcmc.indiana.edu/vol13/issue1/boyd.ellison.html.

Breton, P., Proulx, S. (2002), L'explosion de la communication. Introduction aux theories et aux pratiques de la communication, Paris: La découverte.

Chadwick, A. (2006), Internet Politics. States, Citizens, and New Communication Technologies, Oxford: Oxford University Press.

Charaudeau, P. (2002), “A communicative conception of discourse”, Discourse Studies, 4 (3), 301-318.

Coleman, S., Blumler, J. (2009), The Internet and Democratic Citizenship : Theory, Practice and Policy, Cambridge: Cambridge University Press.

Coleman, S. (2004), "Connecting Parliament to the Public via the Internet", Information, Communication \& Society, 7 (1), 1-22. 
Coleman, S., Moss, G. (2008), "Governing at a distance - politicians in the blogosphere", Information Polity 13, Issue 1-2, 7-20.

Costa, O. (2002), Le travail parlementaire européen et la defense des interest locaux. Les deputes européens dans la gouvernance multi-niveau", in: O. Nay, A. Smith (eds), Le gouvernement du compromis: courtiers et généralistes dans l'action politique, Paris: Economica, 195-226.

de Vreese, C. H., Banducci S. A., Semetko H. A., Boomgaarden H. G. (2006), “The News Coverage of the 2004 European Parliamentary Election Campaign in 25 countries", European Union Politics, 7(4), 477-504.

Egeberg, M., Gornitzka, A., Trondal, J. and Johannessen, M. (2011), Parliament staff. background, career patterns and behaviour, ARENA working paper 10.

Georgakakis, D. (2012), Le champ de l'eurocratie. Une sociologie politique du personnel de l'UE, Paris: Economica.

Georgakakis, D. (2010), “Tensions within Eurocracy? A socio-morphological view”, French Politics, Vol. 8, 2, 116-144.

Gerstlé, J. (2004), La communication politique, Paris: Armand Colin.

Goffman, E. (1959), Presentation of Self in Everyday Life, Garden City, NY: Doubleday Anchor.

Herring, S. C. (2004), “Computer-Mediated Discourse Analysis: An approach to Researching Online Behavior", in: S. A. Barab, R. Kling, J. H. Gray (eds) (2004), Designing for Virtual Communities in the Service of Learning, New York: Cambridge University Press, 338-376.

Jakobson, R. (1960), “Linguistic and Poetics”, in: T. Sebeok (ed.), Style in Language, New York: Wiley, http://akira.ruc.dk/ new/Ret_og_Rigtigt/Jakobson_Eks_15_F12.pdf.

Jackson, N., Lilleker, D. (2011), “Microblogging, Constituency Service and Impression management: UK MPs and the Use of Twitter", The Journal of Legislative Studies 17(1), 86-105.

Lilleker, D., Koc-Michalska, K. (2011), MEPs online: Understanding communication strategies for remote representatives, Paper presented at the ECPR Conference, Reykjavik, September.

Maingueneau, D. (2002), "Analysis of an academic genre", Discourse Studies, 4(3), 319-342.

Marcoccia M. (2004), "Le paradoxe du porte-parole”, in: R. Delamotte-Legrand (ed.), Les mediations langagières, volume II. Des discours aux acteurs sociaux, Publications de l'université de Rouen, 145-155.

McNair B. (2011), An introduction to political communication, London: Routledge.

Meyer, C. P. (1999), "Political Legitimacy and the Invisibility of Politics: Exploring the European Union's Communication Deficit", Journal of Common Market Studies 37(4), 617-39.

Michailidou, A. (2008), “Democracy and New Media in the European Union: Communication or Participation Deficit?", Journal of Contemporary European Research, Vol. 4, No. 4, 346-368.

Oger C., Ollivier-Yaniv, C. (2013), “Discourse analysis and comprehensive sociology. A critical look back at an interdisciplinary research practice", in: S. Bonnafous, M. Temmar (eds), Discourse Analysis and Human and Social Sciences, Peter Lang, 43-58.

Oger, C., Ollivier-Yaniv, C. (2006), “Conjurer le désordre discursif. Les procédés de «lissage» dans la fabrication du discours institutionnel", Mots. Les langages du politique 81, 63-77. 
Oger, C., Ollivier-Yaniv, C. (2003), “Analyse du discours institutionnel et sociologie compréhensive: vers une anthropologie des discours institutionnels", Mots. Les langages du politique 71, 125-144.

Pasquier, M. (2011), Communication publique, Bruxelles: De Boeck.

Podkalicka, A., Shore, C. (2010), “Communicating Europe? EU Communication Policy and Cultural Politics", in: C. Valentini, G. Nesti (eds), Public communication in the European Union: History, Perspectives and Challenges, Cambridge: Cambridge Scholars Publishing, 93-111.

Schmidt, V. A. (2006), Democracy in Europe: the EU and National Polities, Oxford: Oxford University Press.

Spanier, B. (2012), Europe, anyone? The "Communication Deficit" of the European Union Revisited, Baden Baden: Nomos.

Spanier, B. (2010), The Communication Deficit' of the European Union revisited. Structures, Keys Players and the New Communication Policy, University of Zurich, Faculty of Arts, available at: http:/ / dx.doi.org/10.5167/uzh-77676.

Valentini, C., Nesti, G. (2010), “Introduction”, in: C. Valentini, G. Nesti (eds), Public communication in the European Union: History, Perspectives and Challenges, Cambridge: Cambridge Scholars Publishing, 1-22. 

Gabriella Szabo

Center for Social Science, Hungarian Academy of Sciences

\section{GOVCOM 2.0: The Role of Web 2.0 in Communicating EU Presidency}

\section{Introduction}

There is nothing new about the fact that techniques from the non-political environment (popular culture, business, and church) have also been widely used in political communication too. The expanding role of political consultants and the intensive use of marketing mix, segmentation, databases, media/relationship management, image/identity campaigns, audience and adverse party research in political communication are evaluated as a global phenomenon (Gibson-Römmele, 2001; Plasser, 2002; Sussman, 2005).

It is also argued that this is not only just a matter of new tools in the arsenal, it is rather an emerging new attitude in political communication; Public Relations culture which is a way of meaning attribution and valuation in the strategic decisions of political organizations that refers to the political communication "as an activity to establish/maintain relations with the publics." 1 So, examining a seemingly technical question, namely; what role web 2.0 plays in government communication, might have a lot to say about the whole new political communication environment which is inseparably connected with the cultural and societal shifts that appeared in the new millennium (Nash, 2000; Norris, 2000; Tedesco, 2004; Van Santen-van Zoonen, 2009; McQuail, 2010). Analysing the new developments in political communication, such as the PR culture is it, will help in understanding the major changes in the party and government organization and in political human resources too (the prominent role of communication experts and strong focus on the leaders/communicators personality and integrity).

With this study my aim is to identify the patterns of the web 2.0 uses in the Hungarian government communication as undertaking the Presidency of the Council of the European Union between the $1^{\text {st }}$ of January and the $30^{\text {th }}$ of June 2011. The paper is divided into three parts. First, as a theoretical background, the compound of the relational paradigm of $P R$, which is mainly based on the concept of the book 'Public Relations as Relationship Management: A relational approach to the study and practice of public relations', edited by John A. Ledingham and Stephen D. Bruning and the

1 The term of Public Relation culture in political communication resonates the terminus of Marketing culture which is designed by Philip Kotler (1972) and later upgraded by Jennifer Lees-Marshment (2004), Dominic Wring (2005) and Kiss Balázs (2005). 
PR 2.0 approach, which sees social media as the major platform to reach, communicate and stay connected with targeted audiences (Breakenridge, 2008), will be highlighted. This, I believe, provides a solid analytical framework to comprehend the novelty that web 2.0 applications bring into the politics. Then, the methodological issues and the results of the empirical research will be presented. Finally, I will connect the findings of the study to the contemporary scholarly discourses on the transformation of political communication in 2000s (Lilleker \& Michalska, 2011; Lilleker \& Jackson, 2010; Jackson \& Lilleker, 2009; Chadwick, 2009; Osimo, 2008; Coleman, 2005).

\section{Persuasion, relationship management, and community building: approaches of political public relations}

It is not an easy task to point to an exact year when Public Relation appeared in politics. Even Quintus Tullius Cicero and Eric the Red are mentioned as the early representatives of the political PR practitioners (Strömbäck \& Kiousis, 2011:2; Jackson, 2010:2), Sidney Blumenthal in his book of 'The Permanent Campaign', however, argues that despite the long history of formal or informal communication consultants in politics, it was Edward Bernays who provided the foundation for modern political public relations practises (Blumenthal, 1980:12-13). Bernays is credited with the invention, among others, of the media event, the latent message, the appeals of indirection, and he initiated the use of market research in politics too. In his classic essay, 'The Engineering of Consent' (1947), Bernays introduced a coherent concept for political (organizational) communication and this doctrine has been used to understand and influence the voters' (consumers') mind and attitudes for decades.

In the Bernaysian paradigm political PR is a sub-set of propaganda; manipulative promotion of 'good' (conceptually it is what serves the order in society) ideas, values, events or persons. As Larry Tye highlights Edward Bernays regarded Public Relations as the collection of instruments that helped the 'creation of public consent' (Tye, 2002:96). The emphasis on persuasion makes the Bernaysian paradigm of PR a role model for propaganda as well. Since then, the PR toolkit has been exercised in managing political organizations' media relations (e.g. press releases, briefings, meeting journalists, creating media events). The successfully cooperation between the Saatchi \& Saatchi Group and Margaret Thatcher in the late 1970s and the early 1980s demonstrated that PR could also be seen as a complex and permanent service including strategic planning, image building/cultivation, targeting, positioning, relationship management, opposition research and evaluation. Ronald Reagan's presidency is also often cited as an example for extended use of Public Relations not only in campaigns but also in the governmental context (see Denton \& Woodward, 1998:102).

By the end of 1980s, communicative manipulation was perceived as the practice of anti-democrats and oppressors (referring to the Nazi and communist practises) or unethical political behaviour. After all these historical experiences, PR had no fu- 
ture as are accepted concept if it was (self)defined as propaganda or connected solely to persuasive intent. The Grunig \& Hunt's seminal book titled 'Managing Public Relations' (1984) was the first attempt to elaborate not only an ethical version of (political) public relations but an academically-valued theory of it. They define PR in a very plausible way: it is the "management of communication between an organization and its public" (Grunig \& Hunt, 1984:5). Based on this notion, James Grunig and Todd Hunt identifies four models of PR in the modern history of public relation practises. This approach, later referred as Grunigian Paradigm (Moloney, 2006; Jackson, 2010), admits that much PR is propagandistic indeed. In their classification asymmetrical communication is detected in the three (press agentry, public information and two-way asymmetric model) of their four-part typology. Asymmetrical communication is when the (political) organization wants nothing more than to persuade publics for its own benefit. In the Grunigian paradigm this is considered "unethical and socially irresponsible action" (Grunig \& White, 1992:38-42). Grunig and Hunt clearly breaks the link between PR and propaganda by establishing the $4^{\text {th }}$ model of PR; the two-way symmetric model is a dialogical, participative and power distributing concept with the honest attempt to balance the interest of the (political) organization and its publics. Hence, the two-way symmetric model appears to be a normative ideal for PR practitioners. Building upon the two-way symmetric model, James Grunig introduced his new PR approach called the 'Excellence Theory' (Grunig et al., 1992) which identified and described the success factors and best practises in PR. The Excellence Theory suggests that (political) public relation should be a strategically-coordinated management function and an integrated activity. It also should focus on developing equal and fair relationships and maintaining the personalised connections between the (political) organization and its publics. Furthermore, the Excellence Theory argues that symmetrical communication is more effective than doing it asymmetrically, so fostering mutual trust and respect is not only ethical and meets the demands of democracy but pays off in terms of public support/consumer decisions as well.

In spite of the numerous critical remarks on it (Moloney, 2006; Leitch \& Neilson, 2001), the Grunigian paradigm highlights the importance of relationship in conceptualizing organizational communication. The relational perspective sees "PR as the management function that establishes and maintains mutually beneficial relationship between the organization and its public on which the success or the failure of the organization depends" (Cutlip, Center \& Broom, 1994:2). In this regard the scholarly literature on PR activities received new impetus; (political) organizational communication can be seen as the infrastructure of maintaining relationships which resonates the concept of the 'bonding' or 'phatic' function of the communication (Senft, 2009). The key principles of the relational paradigm ${ }^{2}$ are the reciprocity,

2 The relational paradigm of PR has developmented side by side with the contemporary (political) marketing. The relationship marketing is defined pretty much in the way of PR 2.0; it is a strategy designed communication activity to foster interactions and long-term engagements with customers. 
trust, mutual legitimacy, openness, mutual satisfaction, and mutual understanding (Grunig et al., 2002), but without the strong emphasis of moral and ethical aspects (that differentiates it essentially from the Grunigian paradigm).

Having armed with the relational paradigm, PR practitioners in the 1990s started to promote the wider use of conversational communications, which signalled a sharp shift from the mediatized communication to the direct reach and interactions. In transition to $P R 2.0$ the first experience was that the traditional instruments such as broadcast advertising and generic messages did not function in the online spheres. It has also become widely accepted fact that old mind-sets worked even counterproductively in the contemporary communication environment (see the interview with Brian Solis in Breakenridge 2008:261-268). The new approach, PR 2.0, is based on the advocacy of interactive, humanized, personalized and targeted communication. Moreover, the ambition of the PR 2.0 is to create or to get connected to communicative communities in which PR practitioners are 'just' like the other members of the group. To be able to act as accepted members of the community, communicators must become the people he/she wants to reach. Consequently, the differences between the communication patterns of the (political) organization and its publics are vanishing. PR 2.0 is about the collage of peer-to-peer interactivity, a personalized mass communication. It must be emphasised that PR 2.0 should not be equalised with the online PR, it is defined as a whole new attitude which put the participation and connection into the heart its activity no matter if you are online or offline. It is, however, true that the web $2.0^{3}$ and the social media 4 are the excellent fields for PR 2.0 to blossom.

The relational paradigm/PR 2.0 approach deeply concerns political problems as well, for example the one of the (political) community building. The early theorist of nation-building, Karl W. Deutsch argued that individuals/small groups integrated into politically relevant communities when various communication channels allowed people to share common (political) views, habits and culture. Thus, for Deutsch political integration and disintegration directly related to maintaining relations via communication and communicative behaviours (Taylor \& Kent, 2006:302). More precisely, the characters of the political community are largely influenced by the communicative competencies of both governments and citizens. Integration through communication is much more than a one-way, mass media-oriented activity (Dayan \& Katz, 1992); dialogical interpersonal and inter-organizational relations are equally important features of the process. With the help of this approach we can follow how communication flows contribute to the dynamics of political communities (communities around issues, organizations and personalities) as Kruckeberg and Starck argue; "public relation is a way to rebuild community" (1988:xi).

The 'integration through communication' idea may have an implication to one of the most ambitious community building project, to the European integration

${ }^{3}$ For web 2.0 definition see: O'Reilly, Tim (2005), What Is Web 2.0, http://oreilly.com/ web2/archive/what-is-web-20.html, October 6, 2011.

${ }^{4}$ For defintion of social media see: Kaplan, A. M., Haenlein, M. (2010). 
as well..$^{5}$ In this sense, the relational paradigm/PR 2.0 provides a beneficial framework for describing the communication strategies and communication management of political organizations which desire for contributing EU level political discourses. National governments undertaking the task of the rotating Presidency have not only had the duty of organizing meetings and initiating new agendas but the Presidency is considered as an opportunity for building/maintaining the reputation of the country in Europe and vice versa; it is an occasion to increase national publics' confidence in the EU. But the main question is what makes the relational paradigm/PR 2.0, with its utopist-like (some say naive) idea of symmetrical (conversational and interactive) communication, relevant in researching EU Presidency communication. The reason might be the non-hierarchical relations between the government (who undertakes the role of the Presidency) and its perceived publics (EU Institutions, international bodies, and highly professionalized press corps). The independency of the key players and the 'equalizing' logic in their relations (derived from the concept of democratic deficit at the supranational level) create an atmosphere in which any actions of direct manipulation or one-way communications are considered as inadequate, even harmful steps.

Thus, the Presidency can be regarded as a tool for constructing communities in which the feeling of free entities' common belonging can be experienced. It is based on the perception that no matter how different we are in the European Union, we have common interests and issues to deal with. In the language of emotional politics, in spite of all dissimilarities we take care of each other. This sensual dimension is crucial to understand the assessment of the Hungarian EU Presidency communication, since the key publics (such as members of European Parliament, journalists, international bodies) expressed very strong and negative feelings against the Hungarian government. Before discussing it in details, let's see the methodological issues of the study.

\section{Communicating EU Presidency on web 2.0}

\section{Research questions and methods}

In order to assess patterns of web 2.0 applications in government communication of the Hungarian EU Presidency corresponding with the relational paradigm/PR 2.0 approach, the research question was designed as follows:

$R Q$ : What are the main characters of the web 2.0 communication of the Hungarian government in undertaking the role of the rotating Presidency of the Council of European Union?

This overall research question was divided into sub-questions, such as:

$(R Q a)$ : In what ways has web 2.0 been integrated into the strategy of the government communication policy?

\footnotetext{
5 One of the most coherent understandings of European Union as public sphere can be found in: Eriksen \& Fossum (2000).
} 
(RQb): Who are the key publics targeted by the web 2.0 communication?

(RQc): What web 2.0 instruments are applied to reach the targeted publics?

To answer the research questions a combination of the follow-up study of web 2.0 activity in the Presidency communication and semi-structured interviews were conducted. Regarding the follow-up; the official website of the Presidency, ${ }^{6}$ the Facebook ${ }^{7}$ and Twitter ${ }^{8}$ profiles, and blogs ${ }^{9}$ run by the governmental officials were included into the data collection. The pages were carefully observed, regularly downloaded (twice a week) and the governmental web 2.0 activities were registered over the period of the Hungarian EU Presidency (1 ${ }^{\text {st }}$ January-30 June 2011). The statistics of the Facebook profile of the Hungarian government dedicated to the EU Presidency issues were generously provided by the Hungarian Foreign Ministry's EU Presidency Communication Department, other figures were numbered by the authors.

Concerning the interviews, 4 semi-structured interviews were organised during the summer of 2011 with government officials in charge of communicating EU Presidency. The interviews contained a set of closed-ended and open-ended questions which were emailed to the interviewees in advance. All interviews were recorded, transcribed and lasted an average of 60 minutes. All officials were in decision-making positions in departments directly linked to the Presidency communication strategy design and implementation units at the time of the interviews. The technical information about the interviews is listed in the following table:

Table 1

List of interviewees with position they held and the date and place of the interviews

\begin{tabular}{|c|c|c|}
\hline Interviewees & Position & $\begin{array}{l}\text { Date and place of the } \\
\text { interview }\end{array}$ \\
\hline $\begin{array}{l}\text { Dr. URKUTI } \\
\text { György }\end{array}$ & $\begin{array}{l}\text { Head of the Hungarian Foreign Ministry's EU } \\
\text { Presidency Communication Department }\end{array}$ & 28.07.2011, Budapest \\
\hline BAKOS Piroska & $\begin{array}{l}\text { Spokesperson of the Hungarian Presidency } \\
\text { (located in Budapest) }\end{array}$ & 20.07.2011, Budapest \\
\hline $\begin{array}{l}\text { BÖSZÖRMÉNYI } \\
\text { NAGY Gergely }\end{array}$ & $\begin{array}{l}\text { Deputy Head of the Department for Strategic } \\
\text { Communication at the State Secretariat for } \\
\text { Government Communications of the Ministry } \\
\text { of Public Administration and Justice }\end{array}$ & 2.08.2011, Budapest \\
\hline HAJDÚ Márton & $\begin{array}{l}\text { Spokesperson of the Hungarian Presidency } \\
\text { (delegated to Brussels) }\end{array}$ & $\begin{array}{l}\text { 6.09.2011, Budapest-Brus- } \\
\text { sels (via Skype call) }\end{array}$ \\
\hline
\end{tabular}

6 http://www.eu2011.hu/.

7 http://hu-hu.facebook.com/MagyarEUelnokseg.

8 http://twitter.com/\#!/HU_Elnokseg; http://twitter.com/\#!/hajduspox; http://twitter.com/polnerspox; http://twitter.com/\#!/piroskaspox.

9 http://kovacsandkovats.blogspot.com; http://www.eu2011.hu/profile/urkuti-gyorgy; http://www.eu2011.hu/profile/balint-odor. 
The research material will be presented in 3 points corresponding to the research questions of the study. First, the political and organization background, then the strategic issues of the web 2.0 activities, finally the characters of the communicative governmental relations with the identified publics will be discussed.

\section{Political circumstances and organizational background}

Between the $1^{\text {st }}$ of January and 30 $30^{\text {th }}$ of June 2011, Hungary held the rotating presidency of the Council of the European Union for the first time ever in the history of EU. The Hungarian government undertook the Presidency role formulated after the parliamentary elections of April 2010, when the centre-right conservative party alliance (Fidesz and KDNP) won a landslide victory. Having received $52.7 \%$ of the votes and gaining 263 seats out of the 386, the centre-right coalition secured a two-thirds majority in the Hungarian Parliament. Since the government led by PM Orbán Viktor took office, the Parliament has passed a series of new laws which have reshaped the legislative framework of the basic elements of the Hungarian public law and introduced radical measures to consolidate public finance. Especially the confiscation of the compulsory private pension system and the extra taxes on telecommunication companies provoked harsh criticism from EU institutions, European politicians and international bodies..$^{10}$ The extremely heated reactions of the international press and political agents to the new Hungarian media regulation (which came into force on the $1^{\text {st }}$ of January 2011) surprised even the Hungarian government's officials. ${ }^{11}$ Concerns have been raised about the government's, led by Orbán Viktor, capacity to fulfill the task of the Presidency and its commitment towards European values (freedom of press, appreciation the value of a pluralistic civil society, solidarity, respect the rule of law) were also doubted. ${ }^{12}$ The Hungarian government undoubtedly has had to face unfriendly or sometimes even hostile European publics right before the Presidency term started.

The communication team started to be recruited after the conservative government came into office, in June of 2010. Besides the relatively limited time for preparation, the financial frames were also quite tight; the total budget of the Presidency was calculated around $€ 80$ million which was far below the cost of the previous Presidencies. ${ }^{13}$ Despite all the constraints, a triadic architecture of the Presidency communication was established, sharing the workload amongst the Hungarian Foreign Ministry's EU Presidency Communication Department (1), the Department for Strategic Communication at the State Secretariat for Government Communications (2) and Hungary's Permanent Representation in Brussels (3). This approach is

10 Hungary's leader defends controversial laws as EU presidency begins, DW-World.de, January 4, 2011.

11 Hungary: Media law overshadows EU presidency, BBC News, January 7, 2011.

12 Hungary's new media law puts EU presidency in doubt, The Telegraph, October 11, 2011.

13 Hungary's EU presidency budget €80 million, Politics.hu, December 2, 2010. 
rather different from the previous Presidencies which usually created a centralized organizational background for communication.

Dr. Urkuti György, known as well reputed business and EU affairs journalist, was appointed as the head of the Hungarian Foreign Ministry's EU Presidency Communication Department. The staff (19 media/creative communication experts), supervised by Dr. Urkuti, managed the media relations and provided the support for policy communication. The main outcome of their efforts was the official website of the Presidency. ${ }^{14}$ The spokesperson dedicated to the Hungarian publics (Ms. Bakos Piroska, former television journalist) worked also in affiliation with the Hungarian Foreign Ministry.

In the State Secretariat of the Ministry of Public Administration and Justice, the Presidency communication was integrated into the Department of Strategic Communication where it was organized unseparated from the general government communication. Beside his other duties in strategic communication, the Deputy Head of the Department, (Mr. Böszörményi Nagy Gergely, an experienced marketing and branding professional) was in charge of communicating the Presidency. He is also known to having taken part in the introduction of the social media use in the government communication in $2010 .{ }^{15}$ This means not only the creation and operation of government Facebook profiles, but extensive attention and immediate reactions to the dynamics of the communities in social media platforms too. The Department of Strategic Communication is also engaged in the (re)branding of Hungary and governance in the context of Presidency (with 5 permanent staff).

The third actor was the Hungary's Permanent Representation in Brussels which has two spokespersons during the Presidency: Mr. Polner Gergely who specialized in matters related to the COREPER-II (political, financial and foreign policy issues), and Mr. Hajdú Márton who was concerned with issues of COREPER-I (social and economic issues). The Brussels-based spokespersons were selected by the multicircled concours at the end of July 2011 and they were 'borrowed' from the European Commission (Hajdú Márton) and European Parliament (Polner Gergely) for the 6-month-period of the Presidency. The Brussels-based spokespersons were helped by two assistants and a secretary.

The EU Presidency Communication Department in the Hungarian Foreign Ministry (Budapest) and the Brussels-based spokespersons worked in a very close, but horizontal way of cooperation. This meant regular online meetings, daily email and phone communications. While the department in the State Secretariat for Government Communications of the Ministry of Public Administration and Justice operated in occasional and issue-oriented collaboration with the Foreign Ministry Department and the spokesperson to Hungarian publics (Ms. Bakos Piroska).

14 http://www.eu2011.hu/.

15 The idea comes from the FIDESZ's positive experiences of the use of social media during the general election campaign communication in 2010. See: Mihályffy et al. (2011), Kitta (2011). 
Strategic issues: web 2.0 and the key publics (RQa-b)

Even though the written strategy of the presidency communication was not available to the author, the key elements of the plan were highlighted in the interviews. All the interviewees were agreed that there was no question about the integration of Internet, web 2.0 and social media, all were considered necessary tools for effective, economical, but still attractive and inventive Presidency communication. As a strategic principle, the activity was divided into two separate parts: relations with professionals (1) and interactions with the citizens (2).

The communications with professionals (1) targeted the high level officers at EU institutions, Members of European Parliament, senior government officials from the Member States, policy consultants, representatives of NGOs/international bodies, the Hungarian quality media and the international press. This activity mainly covered the relationship building with the so-called 'Brussels bubble'. Connections with the groups of the international networked elite around the EU institutions required the constant care of maintaining interpersonal and dialogical interactions with adequate and accurate information via multiply channels with flexible communication style.

Thus, the Brussels-based spokespersons enjoyed a great deal of trust and support from the Foreign Ministry in translating the communication principles to the day-by-day practice. They were credited to bring and operate new web 2.0 tool without any strong central control such as the blog of spokespersons (Kovács \& Kováts blog, discussed later). The idea of treat EU bloggers as important public and providing them same status as journalists of mainstream media had also came from the Brussels communication team. Even though, bloggers from the community of BlogActive.eu and Bloggingportals.eu (the two main social media platform for blogging EU affairs) actively criticized the new Hungarian media regulations, the initiative of the spokespersons was appreciated. As a result, several spokespersons-bloggers meetings and in March 2011 bloggers grated press accreditation to the European Council, first time ever in the history of EU institutions.

Communication with the Hungarian media was organised by the concept of segmentation. The Hungarian Foreign Ministry's EU Presidency Communication Department established relations with quality press journalists who had professional interest in covering the EU Presidency affairs. The non-EU focused Hungarian press was not targeted by policy issues or general EU information, but rather by the human-interest stories of the Presidency (for example the gastronomic curiosities of Presidency meetings or dress codes in Presidency events). Internet and web 2.0 were considered as strategic tools to reach both media segments.

The work of communication with citizens (2) was located in the Department for Strategic Communication at the State Secretariat for Government Communications of the Ministry of Public Administration and Justice. It was designed to be based on the promotion of events series or activities which were organized under the aegis of the Presidency but without a direct link to it. Two 'flagship' projects were registered for communicating EU as a general idea (brand) for non-professional audiences. 
One was the campaign of the 'Rethink/re-button! Magyar is the Mode' which was introduced in February 2011 as an open competition of fashion and art designers, a fashion show (was held on 8 May 2011, on Europe day) and an art collection with the goal of renewing the Hungarian fashion traditions and encouraging designers to put forward ideas using any element of traditional clothing. The inclusion of the OurFashion blog, one of the three main media partners of the campaign (beside Glamour magazine and a commercial television channel of Hungary), signals the importance of social media in the interest/consumption-based segmentation of government communication, and the broadening horizon of government relationships. The second campaign, called 'Te Szedd!' (You collect!) was introduced as a promotion for voluntary actions in local communities to collect garbage and to recultivate natural heritages. In this campaign, Facebook and Twitter were applied as key instruments for raising awareness and mobilisation for joint activities.

The intensive and extended use of the concept of 'gamification' or 'funware' was also observed in the government interactions with citizens. The terms refer the frequent application of game elements and techniques in non-game environment to encourage well-desires audience actions and generate loyalty or support through involvement (see: Zichermann \& Cunningham, 2011). It typically employs reward mechanisms to maintain the engagement of the targeted groups. Gamification in the governmental context is based on the notion that has shifted from monetary rewards ('pay 1 get 2') to ones in virtual currency conveying social accounts (redeeming, gifting, and exchanging points). The campaigns of the Department for Strategic Communication therefore did not intend to talk about the achievements of the Presidency or the benefits of Hungary's EU memberships. These were absolutely not information campaigns, they were rather aimed to give impetus for the creation or resurrection of communities where there was positive climate of opinions towards the government and the EU.

All in all, the internet and web 2.0 have become an integral part of the strategic thinking about government communication in Hungary. Moreover, the internet is no longer treated as additional and separate issue in communication strategies, the Hungarian EU Presidency shows that the increasingly blurred boundaries between offline and online social relationships has been recognised and taken seriously into account in managing governmental interactions. Consequently, the general approach has changed: it is not the case anymore that the offline and/or mass media-centered communication is translated into the online environment, rather the logic of web 2.0 with its participatory and conversational culture in its fragmented communicative communities determines the strategic and operative aspects of political communication. It is definitely an innovation in the practise of government communication in Hungary.

Web 2.0 relations with publics $(R Q c)$

Presidency on WWW. The official website of the Presidency was launched on the $20^{\text {th }}$ of December 2010 and was available at www.eu2011.hu. The design and the ar- 
chitecture were inherited from the Belgian Presidency; some changes were made in the software to make it compatible with social media platforms. The website was quadrilingual, all information was available in English, in French, in German and in Hungarian as well. It was maintained by the Hungarian Foreign Ministry's EU Presidency Communication Department, the content creation was supervised by officers or partners who had experiences in media or creative communication. Colour coding was introduced to distinguish 'hard news/event' (policy papers and meetings) for EU professionals from soft news (arts, science, life style and gastronomy) for non-EU professionals or for the general public. According to the statistics of the Hungarian Foreign Ministry's EU Presidency Communication Department, 2.7 million page downloads from eu2011.hu domain were registered over the period of the 6-month-long Presidency.

The website was evaluated as the central infrastructure in communicating with journalists. It was a highly informative platform with hundreds of briefings, press releases, photos, videos and full policy paper. It contained event calendar, practicalities for foreign press corps (where to go, where to stay, technicalities of Press Centres) and even an interactive map with updated traffic information. The press accreditation process was also fully internet-based. As important web 2.0 tools personalised newsletters, RSS and the SMS alerts could be subscribed for via the website. Widget code was available too which allowed internet users to establish link on their own websites to the eu2011.hu pages.

The two 'flagship' campaigns of citizen communication had separate websites (gomboldujra.hu; teszedd.hu) which were designed to promote the events/issue. The heads of the Presidency communication, however, intended to keep the website based communication centralised to avoid the production of dozens of microsites in different domains.

Blogging the Presidency. Three blogs were connected to the Presidency communication. The online diaries of Dr. Urkuti György (Head of the Hungarian Foreign Ministry's EU Presidency Communication Department) and Mr. Ódor Bálint (Deputy State Secretary for European Union Affairs of the Hungarian Foreign Ministry) could be reached via the official website. The first entry was published on the $20^{\text {th }}$ December 2010 on the blog of Dr. Urkuti which was followed by 29 entries. Mr. Ódor's first post appeared four days prior to the start of the Hungarian Presidency and he posted 19 entries over six months. In the whole life of the blogs 127 comments arrived from pretty much the same group of commentators: nicknames of 'linquaB', 'basil' and 'jocó' actively commented almost all through the 6 month period. Generally speaking, the comments were positive and encouraging, apart from the entries about the new Hungarian media regulation which were posted in the first phase of the Presidency ( $23^{\text {rd }}$ December 2010 on Urkuti's blog and $7^{\text {th }}$ January 2011 on Ódor's blog). These were the most attractive posts in terms of the number of comments (in sum 59 comments). Both entries were the surprised reactions to the heated international criticism of the new media law. While the comments to Mr. Ódor's entry were mostly supportive, comments to Dr. Urkuti's post were 
rather slamming. The debate tried to be labelled as off-topic by the blog ower. Some comments, however, arrived after the query of the owner of the blog.

The level of interactivity was quite low; the bloggers rarely responded to the comments what they received. The numbers of blog entries declined as the end of the Presidency approached. 37 out of 49 entries were published in the first half of the Presidency (January-March 2011). And the numbers of comments also decreased the end of June 2011 approached.

The third web diary connected to the government, was the Kovács\&Kováts blog. It was launched on the $3^{\text {rd }}$ of February 2011 as the semi-independent initiative of the Brussels-based spokespersons (using the engine of 'blogspot.com'). Kovács\&Kováts were the alter egos of the spokespersons who were "stumbling around the diplomatic world like the odd-couple of Thompson and Thomson in the Tintin comics and this blog is supposed to denote their weekly adventures while working for the Hungarian Presidency" as the intro said. With altogether 43 entries, the aim was to break the tradition that the spokespersons did not speak for themselves. The blog was to be a personal account of the EU and the Presidency, but with respect to the mandate they did not talking about, for example the new media regulation. ${ }^{16}$ By the early April of 2011 the Kovács\&Kováts blog reached 10,000 pageviews as it was communicated on the entry of $6^{\text {th }}$ April 2011 with very few but usually friendly or neutral comments from fellow bloggers interested in EU affairs. The low level of audience activity, in terms of commenting, was discussed several times in the spokespersons's entries. Comments, however, suggested that the best way to attract more comments could have been the use of a provocative, controversial style which was not aimed by the Kovács\&Kováts blog. ${ }^{17}$ In any case, the numbers of entries and comments declined over time as it was observed in the case of DR. Urkuti's and Mr. Ódor's blog.

Presidency on social media. The official Facebook profile dedicated to the Presidency started to operate at the end of December 2010 with 1,514 followers. ${ }^{18}$ Altogether 232 textual and 964 visual entries were uploaded over the Presidency period. All the contents were available in Hungarian and English as well. By the end of June, 4,069 followers were registered to the Hungarian version and 2,543 to the English one. The followers' activity was measured relatively high in sharing the contents of the profile (43,800 sharing was estimated), but it was moderate in commenting. The most commented entries were the gaming one in which souvenirs of the Presidency could be won with 25 likes and 58 comments. ${ }^{19}$ Overtime, the figures

16 See comment no. 5 to the post 'A case for the Financial Times (or how it tripped over a carpet)', February 5, 2011, http://kovacsandkovats.blogspot.com/.

17 See the post and comments of "Kovács \& Kováts at 10,000 - we're learning to fly (but we ain't got wings...)", April 6, 2011, http://kovacsandkovats.blogspot.com/.

18 To compare the figures, the Twitter profile of the Hungarian Government Portal (http://twitter.com/\#!/kormany_hu) has 170 followers (27.10.2011).

19 To put the data in a comparative context see the figures of the Facebook profil of ORBÁN Viktor (leader and PM candicate of the winning Fidesz party) which was launched 3 months prior the General Election of 2010 and by the end of the campaign reached 20,000 people as 
of follower activities showed slight but constant decline in terms of giving likes and comments.

The spokesperson dedicated to the Hungarian publics had a Facebook account with 431 followers.

The citizen campaigns ('Rethink/re-button! Magyar is the Mode' and 'You Collect!') also had Facebook profiles and appeared on the Youtube and Flickr platforms. They, however, were operated with the collaboration of non-governmental partners, so it could be challenging to calculate where the governmental communication ended and where the communications of other entities started. As a matter of fact, that was exactly the purpose of the communication officers at the Department for Strategic Communication at the State Secretariat for Government Communications of the Ministry of Public Administration and Justice. The aim of the government officers was only to come out with the issue and present it in a way which was fascinating enough to grab the attention of the targeted audience and let them contribute or reconfigure the discussion as they wished. The 'flagship' campaigns were the excellent examples of how gamification and other involvement techniques reinforced the feeling of issue ownership in different audience groups.

The use of Twitter can be considered the biggest innovation of the Hungarian EU Presidency, not only in the context of Hungarian government communication, but in the history of Presidencies too. Twitter activity was quite fragmented, 6 profiles were offered for registration. Three were available in English, two in Hungarian and one in French. The Brussels-based team covered the Presidency issues through their personal accounts (hajduspox, polnerspox) in English and general accounts (HU_Presidency/Presidence/Elnökség) were also created to provide short trilingual messages via Twitter. The spokesperson dedicated to the Hungarian publics tweeted in Hungarian (piroskaspox). The official Twitter services were launched on the $15^{\text {th }}$ of December 2010.

In terms of the follower number, the most popular Twitter profiles were the Brussels-based spokespersons' personal accounts (with altogether 1,457 followers) and the English language general Presidency profile (1,108 followers). The tweets of Ms. Bakos Piroska were followed by 175 people. And the French version of the general Presidency profile was registered 120 followers. The most active user was Mr. Polner Gergely who released 693 tweets between the $1^{\text {st }}$ of January and the $30^{\text {th }}$ of June 2011. 335 tweets were counted on Hajdú Márton's profile and it was 204 on Ms Bakos Piroska's one.

The general Presidency profiles were a kind of alert service: the tweets usually provided notification on the latest updates of the official webpage and the upcoming events. This profile targeted the press corps which was covering the Presidency affairs.

followers. The likes on the most popular entry was numbered as 1,238 and the most commented post attracted 411 reactions. See: Mihályffy et al (2011). The Facebook profile of the Hungarian Government Portal (http:/ / hu-hu.facebook.com/kormanyzat) currently has 1195 likes (27.10.2011). 
The spokespersons mainly used their profiles to react to the tweets of their followers. The pattern of the dialogical interactivity was mainly observed in the Twitter activity of the Brussels-based spokesperson whose partners in Twitter communication were dominantly from the Brussels bubble. Thus, the Twitter profiles could be seen as a platform for publicly opened interpersonal chatting of the community. This conversation was rather fragmented, since a tweet could not be longer than 140 characters. That obviously did not allow for the exchange of opinions in a substantive way. Twitter, however, contributed to active participation in the communication circle of a certain group and maintained relations with members, signalling the attentions to the group activity and the acceptance of the group rules. The spokespersons seemed to be aware of the golden rules of tweeting such as keep it short (less than 120 character), be responsive, feel free to express personal feelings, know who follows you and who you are following, etc. ${ }^{20}$ as contributing to the communication flow around the Hungarian EU Presidency via Twitter.

The web 2.0 patterns of the Presidency communication are summarised in the Table 2 below.

Table 2

Summary of the web 2.0 use in communicating the Hungarian EU Presidency

\begin{tabular}{|c|c|c|c|}
\hline PUBLICS & $\begin{array}{l}\text { Professional: journalists, blog- } \\
\text { gers, officers (EU institutions, } \\
\text { MPs, MEPs, Member States' } \\
\text { Gov., international bodies), con- } \\
\text { sultants, activists }\end{array}$ & $\begin{array}{l}\text { Non EU related press } \\
\text { (Hungary): tabloids, } \\
\text { life style magazines, } \\
\text { free sheets, online por- } \\
\text { tals. }\end{array}$ & $\begin{array}{l}\text { Citizens } \\
\text { (Hungary) }\end{array}$ \\
\hline $\begin{array}{l}\text { WEB } 2.0 \\
\text { TOOLS }\end{array}$ & \begin{tabular}{|l} 
RSS \\
SMS alerts \\
Google maps \\
Widget \\
Twitter \\
Blogs \\
(personalised)Newsletter
\end{tabular} & $\begin{array}{l}\text { Facebook } \\
\text { (Youtube, Flickr) }\end{array}$ & $\begin{array}{l}\text { Facebook } \\
\text { (Youtube, Flickr) }\end{array}$ \\
\hline $\begin{array}{l}\text { CHARACTER OF } \\
\text { COMMUNICATION }\end{array}$ & $\begin{array}{l}\text { personalised } \\
\text { multi-channelled } \\
\text { two-way } \\
\text { dialogical (Twitter) }\end{array}$ & $\begin{array}{l}\text { issue/event orienta- } \\
\text { tion human interest } \\
\text { stories }\end{array}$ & $\begin{array}{l}\text { issue/event } \\
\text { orientation } \\
\text { gamification }\end{array}$ \\
\hline AIMS & $\begin{array}{l}\text { agenda setting, relationship } \\
\text { management/community } \\
\text { building }\end{array}$ & infotaining & $\begin{array}{l}\text { issue ownership } \\
\text { loyalty building }\end{array}$ \\
\hline
\end{tabular}

As table 2 shows the professionals-targeted communication was armed mostly with web 2.0 features. In the citizen communication, social media played primary role for establishing segmented and direct connections with audiences which could

${ }^{20}$ Inspired by the list of Garin Kilpatric, marketing expert and the author of The Twitter Tool Book (2010). 
be evaluated as evidence of the decline of the mass media-centered governmental communication approach.

\section{Conclusions}

The Hungarian EU Presidency was an extraordinary occasion for the ruling government to make itself visible at the EU level which means political, diplomatic, management and communication tasks at the same time, and the results achieved in these all form a part of the evaluation of the Presidency performance.

The aim of this study was to provide empirical evidence for the evaluation of the web 2.0 based efforts of the Hungarian government in communicating EU Presidency. The results support the thesis of the presence of Public Relation culture in government communication having found that the strategic angle of the government communication was relationship building with key publics and web 2.0 was seen as a tool to facilitate the maintenance of the connections. The research findings suggest that PR 2.0 as a mind-set and web 2.0 as toolkit with its interactive, two-way and personal nature was fully integrated into the Presidency communication. In spite of the negative reputation of the centre right Hungarian government, the Presidency communication team managed to create a supportive online environment through web 2.0 profiles in which the audiences were targeted in a segmented way.

The social media platforms, mainly the spokespersons' personal Twitter/Facebook profile and blog entries, depicted real faces around the Presidency. The new online instruments contributed to the attempt of reconfiguration of the patterns in communicating EU affairs. The key element of the change was the rejection of the top-down and command-control style of communication. Instead, clear steps were observed towards a more cooperative and networked style of government communication which targeted not only the traditional mass media, but an extended circle of stakeholders too (bloggers, for example).

In this sense, 'medium was (one of) the (symbolic) message' of the Hungarian government as signalling the possibilities of dialogical and personalised interactions. Concerning the reciprocity, the Presidency communication was successfully embedded in the cultural and communication context of the 'Brussels bubble' which has been considered as the most characteristics community (public) around the European Union. In this regards, Ihave detected well-designed web 2.0 communication routes (see Twitter) in the elite's discussions. The citizen-targeted communication of the Hungarian EU Presidency highlighted the possible ways how consumption (see'Rethink/re-button! Magyar is the Mode' campaign) and social values (see 'Te Szedd!' garbage collection campaign) could be conceptualized as fundaments of political interactions. Nevertheless, the Presidency communication has failed to connect its targeted publics (roughly speaking professionals and citizens) to each other. The government kept its key publics strictly separated which might be evaluated as huge problem since it maintained the democratic deficit in 
the European political space. Alternative explanation is proposed from the viewpoint of Public Relations; the government responded the different needs in various ways in order to satisfy them all. The non-EU professional publics were perceived not to be interested in core EU topics, so they were rather targeted by human interested stories of the Presidency or cultural events linked to EU. The PR culture as identified in the study also demonstrated the possible ways of integrating emotions (humour, sense of belonging, etc.) and life styles (fashion, gastronomies, etc.) in communicating EU affairs.

The research diagnosed that the impacts of web 2.0 can be profound on governments' strategic thinking without the promise of revolutionary changes in the structure of governance. The web 2.0-based government communication did not delegate consultancy or decision making rights to citizens in the issues of the Presidency. In this regard, social media use does not imply the absolute denial of the current paradigm in governance, but it raises questions about the notions of basic concepts of political communication (such as political community and participation). We have to revise what institutionalised political communication means today when the web 2.0 with its real-time, direct and participatory logic further adds to the blurring institutional borders in all realms of society; and how political communities can be identified when they are in flux rather than a stable entity. The concept of participation also needs to be rethought again: for a long time, we have know that participation is much more than voting, consequently political communication should be much more than just voter mobilising for the one single day of the election. This might require paradigmatic renewal at the mezzo-level of political science, in the theories of political communication.

\section{References}

Bernays, E. L. (1947), “The Engineering of Consent", The Annals of the American Academy of Political and Social Science, No. 250, 113-120.

Blumenthal, S. (1980), The Permanent Campaign, Boston, MA: Beacon Press.

Breakenridge, D. (2008), PR 2.0: New Media, New Tools, New Audiences, FT Press.

Bruning, S. D., Ledingham, J. A. (2000), Public Relations as Relationship Management: A Relational Approach to the Study and Practice of Public Relations, Lawrence Erlbaum Associates.

Chadwick, A. (2009), “Web 2.0: New Challenges for the Study of E-Democracy in an Era of Informational Exuberance", I/S: Journal of Law and Policy for the Information Society 5(1), 9-41.

Coleman, S. (2005), "Blogs and the new politics of listening", Political Quarterly 76(2), 272-280.

Cutlip, S. M., Center, A. H., Broom, G. M. (1994), Effective public relations (6 $6^{\text {th }}$ ed.), Englewood Cliffs, NJ: Prentice-Hall.

Denton, R. E., Woodward, G. C. (1998), Political Communication in America, New York: Praeger. 
Dayan, D., Katz, E. (1992), Media Events. The Live Broadcasting of History, Cambridge: Harvard University Press.

Eriksen, E. O., Fossum, J. E. (eds) (2000), Democracy in the European Union - Integration through Deliberation?, London: Routledge.

Gibson, R., Römmele, A. (2001), “A Party Centered Theory of Professionalized Campaigning", Harvard International Journal of Press Politics 6 (4), 31-44.

Grunig, J., Hunt, T. (1984), Managing Public Relations, New York: Holt, Rinehart and Winston.

Grunig, J., White, J. (1992), “The Effect of Worldviews on Public Relations Theory and Practice", in: J. Grunig et al. (eds), Excellence in public relations and communications management, Hillsdale-New Jersey: Lawrence Erlbaum Associates, 31-65.

Grunig, L. A., Grunig, J. E., Dozier, D. M. (2002), Excellent public relations and effective organizations: A study of communication management in three countries, Mahwah, NJ: Erlbaum.

Jackson, N. (2010), Political Public Relations: spin, persuasion or relationship building?, available at: http://www.psa.ac.uk/journals/pdf/5/2010/1192_1076.pdf.

Jackson, N., Lilleker, D. G. (2009), “MPs and E-representation: Me, MySpace and I”, British Politics 4 (2), 236-264.

Kaplan, A. M., Haenlein, M. (2010), “Users of the world, unite! The challenges and opportunities of Social Media", Business Horizons 53 (1), 59-68.

Kiss, B. (2005), "Marketing Culture and the Celebrity Politician. The Restyling of Politics in Hungary", MTA PTI Working Papers, No. 2.

Kotler, P. (1972), “The Generic Concept of Marketing”, Journal of Marketing, April.

Kruckeberg, D., Starck, K. (1988), Public relations and community: A reconstructed theory, New York: Praeger.

Lees-Marshment, J. (2004), The Political Marketing Revolution, Manchester University Press.

Leitch, S., Neilson, D. (2001), “Bringing publics into public relations: new theoretical frameworks for the practice", in: R. L. Heath (ed.), Handbook of Public Relations, London: Sage, 127-138.

Lilleker, D., Jackson, N. (2010), “Towards a more particpatory style of election campaigning: the impact of Web 2.0 on the UK 2010 General Election", Internet Policy 2(3).

Lilleker, D., Michalska K. (2011), MEPs online: Understanding communication strategies for remote representatives. Paper presented at the European Consortium of Political Researchers Conference: Reykjavik (Iceland), August.

Mihályffy, Z., Szabó, G., Takács, M., Ughy, M., Zentai, L. (2011), “Kampány és Web 2.0. A 2010-es országgyúlési választások online kampányainak elemzése", in: P. Sándor, L., Vass (eds), Magyarország politikai évkönyve 2010-ről, Demokrácia Kutatások Magyar Központja Közhasznú Alapítvány Budapest, DVD Edition.

Moloney, K. (2006), Rethinking Public Relations: PR Propaganda and Democracy, $2^{\text {nd }}$ edition: The Spin and the Substance, Routledge.

McQuail, D. (2010), McQuails's Mass Communication Theory (6 $6^{\text {th }}$ edition), London: Sage.

Nash, K. (2000), Contemporary Political Sociology, United Kingdom: Wiley-Blackwell.

Norris, P. (2000), A Virtuous Circle: Political Communications in Postindustrial Societies, Cambridge: Cambridge University Press.

Osimo, D. (2008), Web 2.0 in Government: why and how European Union, Joint Research Centre, Institute for Prospective Technological Studies. 
Plasser, F., Plasser, G. (2002), Global Political Campaigning. A Worldwide Analysis of Campaign Professionals and their Practices, Westport: Praeger.

Senft, G. (2009), “Phatic communion”, in: G. Senft, J.-O. Östman, J. Verschueren (eds), Culture and language use, Amsterdam: John Benjamins, 226-233.

Strömbäck, J., Kiousis, S. (eds) (2011), Political Public Relations. Principles and Applications, New York: Routledge.

Sussman, G. (2005), Global Electioneering. Campaign Consulting, Communications, and Corporate Financing, Lanham: Rowman \& Littlefield Publishers.

Taylor, M., Kent, M. L. (2009), "Public Relations Theory and Practise in Nation Building”, in: C. H. Botan, V. Hazleton (eds.), Public Relations Theory II, Taylor \& Francais, 299-314.

Tedesco, J. C. (2004), “Changing the Channel: use of the Internet for communication about politics", in: L. L. Kaid (ed.), Handbook of Political Communication Research, Routledge.

Tye, L. (2002), The Father of Spin: Edward L. Bernays and The Birth of Public Relations, Picador.

Van Santen, R. A., Van Zoonen, L. (2009), Popularization and personalization in political communication. A conceptual analysis, Paper presented at the 59th Annual Conference of the International Communication Association (ICA), May 21-25, Chicago.

Wring, D. (2005), The Politics of Marketing the Labour Party, Hampshire: Macmillan-Palgrave.

Zichermann, G., Cunningham, C. (2011), Gamification by Design. Implementing Game Mechanics in Web and Mobile Apps, O'Reilly Media. 
Arjen van Dalen

University of Southern Denmark

\section{The Changing EU Presidency and the Media Agenda at Home: Coverage of the Danish 2002 and 2012 Presidency Compared}

\section{Introduction}

"The Danish EU Presidency is two months old. Rarely have the media covered the EU so intensively. Denmark is the imperative center: Europe's navel."

"The Danish media could very well continue their eagerness to cover the EU under the next Presidencies. Or do we have to wait until 2015, or what was the next time Denmark holds the Presidency again?"

Charlotte Fischer, candidate for member of Parliament (R), Politiken, 2 August 2002

These are two quotes from a discussion piece by then candidate - MP Charlotte Fischer about Danish media coverage of the 2002 EU Presidency. When Denmark held the Presidency of the Council of the EU, also called the "EU Presidency", in the second half of 2002, Danish newspapers and television covered the EU intensively (de Vreese, 2005). Coverage often applied a national angle, but compared to other periods when the EU was largely absent, the intensive coverage was seen as a positive change. As the opinion piece by Fischer illustrates, the rotating Presidency has traditionally been a good opportunity to bring the EU closer to home and put the EU on the national media agenda (Boomgaarden et al., 2010).

Fischer feared that since the media only cover the EU intensively when the country holds the Presidency, it would take a long time before the EU would receive this type of coverage again in Denmark. The next Danish Presidency took place in 2012 (not in 2015 as Fischer wrote), in a completely different context. By then Brussels had become the permanent location of meetings between the heads of state or government of the member states and Herman Van Rompuy was installed as permanent President of the European Council. Compared to other EU actors like the European Parliament, the role of the presiding government diminished. Given the different institutional role of the Presidency since the Lisbon Treaty, it is questionable whether the Presidency still generates the same headlines in the presiding country.

This chapter discusses the consequences of the changing role of the rotating Presidency from a communication perspective. Contrasting the 2012 Presidency with the 2002 Presidency the chapter describes how media debate in the presiding 
country has changed. The following questions are addressed: How visible and prominent is the Presidency in the media after changes introduced by the Lisbon Treaty? Which are the new key moments during the Presidency for the media? Did the 2012 Danish Presidency generate debate in the media about the EU and was the debate inclusive of the general public?

To address these questions, the chapter proceeds as follows. First, the importance of media debate about the EU is discussed and three dimensions are presented along which debate should be assessed: visibility, inclusion and contestation. This is followed by an overview of previous research on media coverage during Presidencies. Based on a presentation of the main institutional changes introduced by the Nice and Lisbon Treaty, the context and characteristics of the 2002 and 2012 Presidencies are briefly introduced followed by an analysis of the visibility of the EU in the media and debate about the EU. These results are discussed in the light of the communication strategy and goals of the Danish government during the 2012 Presidency. ${ }^{1}$

\section{Debate about Europe in national media: three dimensions}

'Permissive consensus' has long characterized European integration, where decisions were made by elites, without much interest from or debate among the general population (Lindberg \& Scheingold, 1970). However, over time citizens have become increasingly critical of the EU (Hix, 2008) and no longer silently agree a priori with growing Europeanization. This became for example clear during the 2005 referendums in France and the Netherlands, where the public voted against the European Constitution. Simultaneously EU-skeptic parties have been on the rise in Europe. This more critical stance of the public towards European integration has underlined the need for public discussion about the EU. Meyer (2005) argues that 'compensatory Europeanization' of national public discourse becomes essential as the EU gets more powerful: national publics need to be well informed about the EU by the media. However, in practice, public and media debate about the EU has long been missing, and knowledge and attention for EU politics among the public have generally been low. The EU acknowledged the existence of such a 'communication deficit' in the White paper on a European Communication Policy (European Commission, 2006), which lays out measures to enhance debate and dialogue about Europe. Such debate would increase the legitimacy of the European institutions and policy decisions and would ideally take place at two levels: both at the European level and at the national level (De Beus, 2010:23).

The mass media play a central role in this alleged communication deficit, since they are the public's prime source of information on the EU and a key facilitator of a public sphere where debate takes place. A truly European public sphere, mirror-

1 I am gratefull to Agnieszka Stępińska, Mette Buskjær Christensen, Niels Lachmann and Christilla Roederer-Rynning for their help and comments. 
ing the national public sphere with pan-European media in which voices from different European countries exchange views in an open debate, received limited empirical support (Machill et al., 2006). In practice debate about the EU is mostly concentrated within national borders (Brüggeman \& Kleinen-von Königslöw, 2009; Koopmans \& Stratham, 2010). In the words of De Beus (2010:32) "the European public sphere is home grown." Following Schmidt (2006) such debate about the EU within national borders is a necessity, since the democratic deficit of EU politics is also present at the national level. The lack of deliberations in the member states about the effect of Europeanization at home is an important problem and might have strengthened populist parties (Schmidt, 2006:4).

Given the importance of media debate about Europe at the national level, what should this debate look like? Koopmans and Stratham (2010:5) mention three key dimensions to assess whether media coverage of Europe indeed "carries political debates over Europe to general publics:" visibility, inclusiveness and contestation.

First, for citizens to be aware of politics at the European level requires that the media make the European Union and its institutions visible. Previous research has shown that attention for politics at the European level is generally low and only peaks around key events. Peter and de Vreese (2004:16) therefore compare the EU to the moon: "though of major influence on the ebb and flow of Europe, it is only cyclically fully visible."

A second criterion is inclusiveness of publics: the degree to which non-political actors and in particular the general public has access to and is included in policy decisions. An important indicator here is the extent to which citizens are "included within public debates about the decision making processes of European multilevel governance." (Koopmans \& Stratham, 2010:5). In practice EU debate is dominated by politicians, in particular government actors, while civic society actors and the general public are mostly absent (Koopmans \& Stratham, 2010:291; de Vreese et al., 2006).

A third key dimension is contestation. To improve the legitimacy of the EU and its decisions, the actions and proposals need to be subject of thorough discussion. This has implications for the media which should "not just inform, but also provide a platform for debate" (Van Noije, 2007:266). According to Koopmans and Stratham (2010), coverage of the EU that is more visible and accessible to more non-elite voices would automatically include more conflict and debate. Previous research has shown that conflict is an important news value and that the EU is covered more in countries where there is elite debate about the course of the European Union (Boomgaarden et al. 2013).

\section{The media and the changing Presidency}

Previous research has shown that the EU has not featured prominently on the national media agenda (Boomgaarden et al., 2010). One of the exceptional periods where Europe generated headlines and made the EU accessible to citizens was 
when the member state held the EU Presidency. However, this might have been affected by changes in the institutional role of the Presidency introduced by the Nice and Lisbon Treaty.

Several studies have shown that holding the Presidency used to bring the EU closer to home. Norris (2000) and de Vreese (2003) pointed out that EU coverage peaked around European Council meetings of the EU's heads of state or government in so-called European Summits, which used to be chaired by the country holding the Presidency. Peter and de Vreese (2004) studied differences in summit versus routine periods in television news in Denmark, France, Germany, Netherlands and the United Kingdom. Their study confirmed that the EU was more visible and more prominently covered during summit periods. Traditionally, these summits used to take place in the presiding country, which led to considerable coverage in that country (de Vreese, 2005).

The Nice Treaty introduced a first change in the set-up of the European Presidency. Since 2003 EU summits no longer take place in the presiding country. Instead Brussels became the permanent location of the EU council meetings between heads of state or government. Boomgaarden et al. (2010) showed that this had a negative influence on the visibility of the EU in the presiding country, since Council meetings in Brussels were covered less than Summits in the Presiding country. For journalists the fact that the home country holds the Presidency does not make the Brussels summit as relevant as meetings at home. "If the country holding the Presidency organizes an EU summit in Brussels, as is the case from 2003 onwards, this does not cause a significant increase of EU news visibility in that country." (Boomgaarden et al., 2010:516).

The study by Boomgaarden et al. analyzed media coverage until 2006. Since then the role of the EU Presidency has changed considerably due to the implementation of the Lisbon Treaty (Beach, 2012). Like the Nice Treaty, these changes are likely to affect the visibility of the EU on the media agenda. Some of the major changes introduced by the Lisbon Treaty were: (1) split of the European Council from the Council of the EU. Meetings by the heads of state or government are no longer part of the Presidency; (2) introduction of a permanent President of the European Council, who leads the summits by the heads of state or government. The first President was Herman van Rompuy; (3) introduction of a High Representative of the Union for Foreign Affairs and Security Policy, who chairs the Council meetings of the Foreign Affairs ministers. The first Representative was Catherine Ashton; (4) three consecutive Presidencies work together in a Trio Presidency to provide more consistency. Denmark worked together with Poland and Cyprus; (5) more influence for other actors than the Presidency, for example an enhanced status of the European Parliament (Danish Presidency, 2012c; Manners, 2013).

After these changes in the Lisbon Treaty, in addition to the earlier decision to make Brussels the permanent location for EU summits, the character of the Presidency changed. It is now seen as "more about exercising administrative capacities than performing political leadership" (Christensen \& Nielsen, 2013:84). These 
changes are also likely to affect the possibility of the Presidency to bring the EU closer to home and dominate the media agenda. The EU summits, which generated most media attention, are no longer chaired by the presiding country and no longer take place there. This could lead to lower peaks in media attention. Working together with two other Presidencies could limit the possibilities to give the Presidency an own distinct profile. The more important role of the Parliament may mean that the Parliament can influence the media agenda about the Presidency. In addition, the role of political agenda-setter became less important for the Presidency, while the role as neutral mediator between different European institutions became more important (Christensen \& Nielsen, 2013). Such a role as honest broker could make the Presidency less outspoken about its own views, which in turn could limit media interest.

Nevertheless, holding the Presidency may still be a possibility to generate public and media attention, although on a lower level than before 2003. The Presidency is still seen as a chance to "strengthen public support for the EU in the Member States" (Danish Presidency, 2012c). Consequently, the Danish Government that held the Presidency in 2012 described the Presidency as a "good opportunity to place focus on the EU in Denmark" (Danish Presidency, 2012a). To do so the Danish EU Presidency organized information activities and debate events in Denmark during the 2012 Presidency. In addition "openness and transparency" were highlighted as important values of the Presidency, also in the relations with the press (Danish Presidency, 2012a).

\section{Changing Presidency, changing media debate?}

To study the impact of the institutional changes in the Presidency on media debate in the presiding country, this chapter compares the 2002 and 2012 Danish Presidencies. Media debate will be compared along the three dimensions presented by Koopmans and Stratham. First, the visibility of the Presidency in the media is studied, comparing the overall number of articles about the Presidency in 2002 and 2012 and their prominence in the newspaper. The weekly change in media visibility is compared to see what the new key moments are when the Presidency makes headlines in the media. To study the other two dimensions, inclusiveness and contestation, the articles about the Presidency in the opinion section of the newspaper are studied. This section of the newspaper includes letters to the editor, opinion pieces, columns and editorials. The number of opinion pieces during the 2002 and 2012 Presidency are compared as a proxy for contestation on the media agenda. The letters-to-the-editor section has been described as "one of a few arenas for public discussion by regular citizens, and can be seen as a key institution of the public sphere" (Habermas, 1989 in Wahl-Jorgensen, 2002:69). Although the contributions by the audience included in the newspapers are selected by the editors, this is one of the few sites for public deliberation in the newspapers (Wahl-Jorgensen, 2002). 
Therefore, this chapter looks at the authors of the opinion pieces and letters-to-the-editor as an indicator for the inclusiveness of citizens in the debate. The share of opinion pieces written by the general audience is compared to the share of opinion pieces written by politicians, the media, experts and representatives of interest groups.

The 2002 and 2012 Danish Presidencies took place in very different contexts, which were shaped by the institutional changes introduced by the Lisbon Treaty. The Danish Presidency 2002 had cumulated in the Copenhagen Summit (12 and 13 December), where negotiations about the Enlargement were closed. In the European Council conclusions, the heads of state or government described the Copenhagen Council as "an unprecedented and historical milestone" (European Council Conclusions in Friis, 2003:49). The 2012 Presidency took place in a completely different context. The expansion of the EU to 27 countries, the implementation of the Lisbon Treaty combined with the enduring economic crisis, had a strong impact on the Presidency. Contrary to 2002, Denmark did not chair the summits of the heads of state or government, which took place in Brussels. The Danish Presidency was part of a trio of Presidencies together with two countries with different ambitions, experiences and priorities: Poland and Cyprus. According to Manners (2013:74) this new context "relegated the Danish Presidency to a supportive role in the larger issues of the time." The two main tasks of the presiding country were to represent the Council when negotiating with the Commission or the European Parliament and to lead the meetings in the Council of the EU (Danish Presidency, 2012c). These meetings mainly took place in Brussels and Luxemburg, but in addition a number of informal meetings were organized in Denmark.

These differences between 2002 and 2012 show that the institutional changes in the working of the EU institutions changed the character of the Presidency. The political circumstances and the significance of the outcome of the Presidency were also different. This will be taken into account when analyzing and discussing the outcome of the content analysis.

One center-left and one center-right leaning broadsheet newspaper (Politiken and Jyllands Posten, respectively) are included in the study. Politiken and Jyllands Posten have often been used in previous studies of EU coverage (de Vreese et al., 2006). Since broadsheet newspapers generally have a different type of coverage of the EU than other newspapers (de Vreese et al., 2006), also two tabloid newspapers were included: EkstraBladet and BT. Newspaper articles were collected through the Danish newspaper database Infomedia using three sets of keywords. ${ }^{2}$ In order to establish a link between the Presidency and media coverage, keywords were chosen which refer narrowly to the Presidency, rather than to the EU in general (for a similar approach see Blach-Ørsten, 2012). For the 2002 Presidency the period 1 July 2002 until 2 January 2003 was analyzed, and for the Presidency 2012 the period was 1 Jan-

2 ("EU presidency") OR ("EU” AND “presidency") OR ("Danish" AND "presidency") in the headline, subheading or first paragraph. 
uary 2012 until 2 July 2012. Where possible the results of the content analysis will be compared to the findings de Vreese (2005) and Blach-Ørsten (2012) who analyzed media coverage during several weeks of respectively the 2002 and 2012 Presidency. Although these studies had a different focus and studied another time frame, a comparison of the results adds to the validity of the findings of this study.

\section{A less visible and less inclusive Presidency}

A comparison of the media coverage of the 2002 and 2012 shows that the attention for the EU Presidency diminished and showed lower peaks. Figures 1 and 2 show the number of articles covering the Danish Presidency during the second half of 2002 and the first half of 2012. ${ }^{3}$ In 2002191 articles in Politiken and 302 articles in Jyllands Posten dealt with the Presidency. In 2012 coverage in Jyllands Posten was considerably lower (104 articles). Coverage in the two tabloids almost halved. The only exception is Politiken, where almost the same number of articles referred to the Presidency in 2012 (171) as in 2002. At the same time, the prominence of the Presidency in both broadsheet papers diminished. While in 200218 articles appeared on

Figure 1. Visibility of the Danish EU Presidency in the second half of 2002 in Danish broadsheet and tabloid newspapers

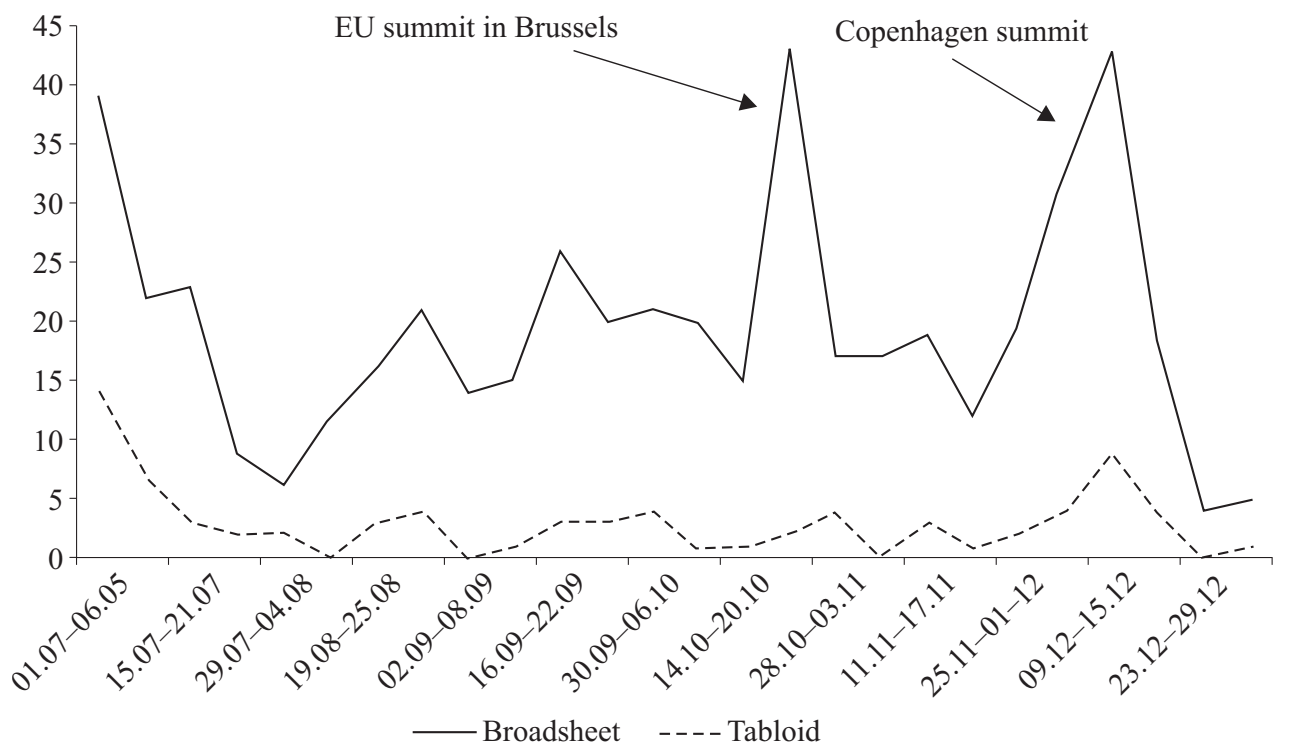

Note: Broadsheet: nr of articles in Politiken and Jyllands Posten; tabloid: number of articles in EkstraBladet and BT.

3 Since the pattern of visibility was similar in the two broadsheets and in the two tabloid newspapers these are combined. 
the frontpage of Politiken, this was only the case for five articles in 2012. For Jyllands Posten the number of articles on the frontpage about the Presidency declined from 21 to only one. No frontpage articles in the tabloid newspapers dealt with the Presidency in 2012.4

\section{Figure 2. Visibility of the Danish EU Presidency in the first half of 2012 in Danish broadsheets and tabloid newspapers}

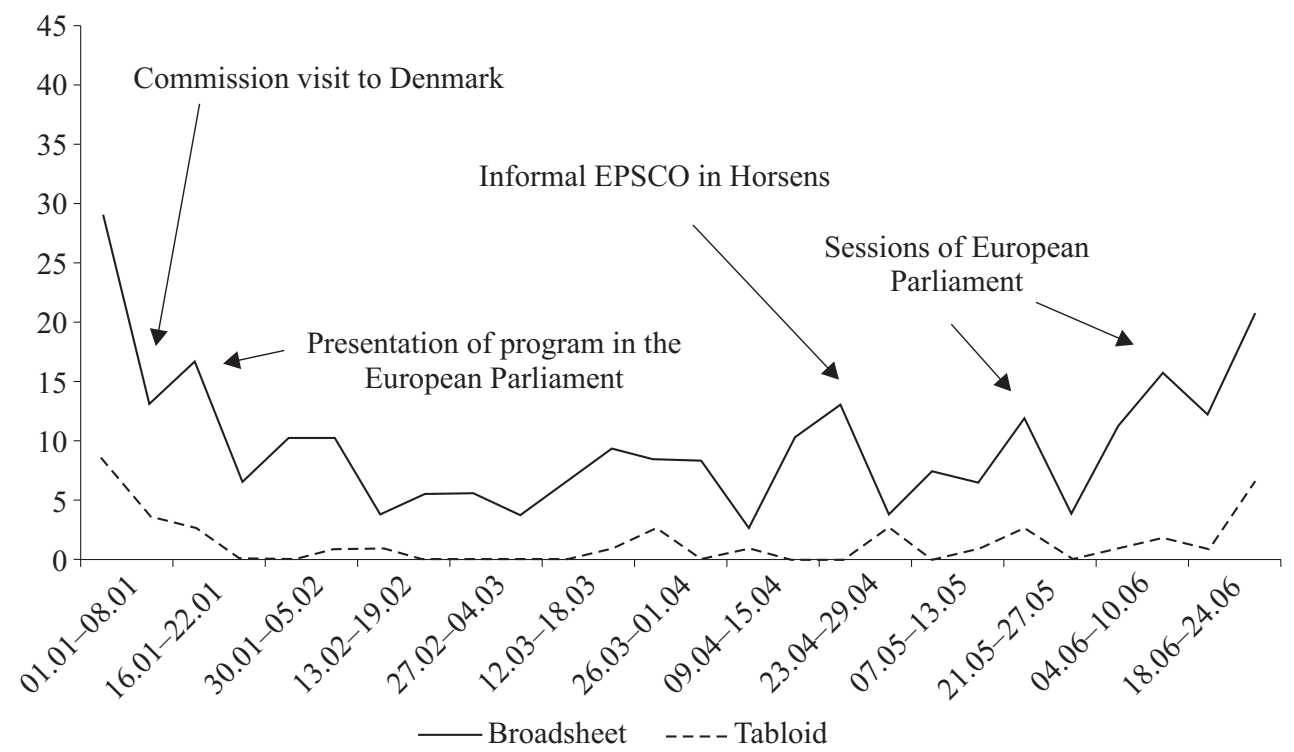

Note: Broadsheet: nr of articles in Politiken and Jyllands Posten; tabloid: number of articles in EkstraBladet and BT.

The 2002 coverage showed sharp peaks around the meetings of the European Council in Brussels (24 and 25 October) and the Copenhagen Summit (12 and 13 December), with over 40 articles in the broadsheet newspapers and attention for the Presidency on the front-page. Previous studies showed that the EU Presidency receives more attention when meetings take place in the Presiding country than in Brussels. This was also the case in 2002, in particular for the tabloid newspapers. Although the peak in media attention in the broadsheets was similar for the Brussels and Copenhagen meeting, the Copenhagen summit generated more coverage in the week leading up to the summit. In 2012 the meetings of the European Council (no longer chaired by Denmark) did no longer generate so much media attention. The influence of the formal Council meetings on 1-2 March and 28-29 June 2012 on media coverage of the Presidency can hardly be noticed, as Figure 2 shows. In sum, while the EU Presidency generated considerable media coverage before the imple-

4 Coverage of the 2012 EU Presidency in the main news broadcasts on television and on radio was also low, with less than two stories per month on average in each broadcast. 
mentation of the Nice and Lisbon Treaty with high peaks around the EU summits, this is no longer the case in 2012.

This raises the question what the new key moments are in which the EU Presidency is prominently covered. Like in 2002, the start of the 2012 Presidency led to reflections in the Danish media on the tasks and challenges that awaited the Danish government. Media attention remained relatively high in broadsheet and tabloid newspapers during the first three weeks, which included a visit of the commissioners to Denmark and the presentation of the Presidency program by Danish prime minister Helle Thorning-Schmidt in the European parliament. After this start, media interest strongly diminished, in particular in the tabloid press, where coverage did not exceed five articles a week until the last week of the Presidency (see also Blach-Ørsten, 2012). Coverage in the broadsheet press peaked again in April when informal meetings of the Employment, Social Policy, Health and Consumer Affairs Council (EPSCO) took place in Horsens. ${ }^{5}$ In periods where meetings look place in Brussels, for example at the end of February, there was less attention (see also Blach-Ørsten, 2012). However this effect seems to be limited to the broadsheet newspapers. In the tabloid newspapers, coverage of the EU Presidency was generally low and was not influenced by location. In April, May and June the Presidency received more coverage in the weeks when the European Parliament met. In the final weeks of the Presidency, media attention peaked again when the media looked back at the accomplishments of the Danish government.

In sum, media coverage of the 2012 Presidency was considerably different from the pre-Lisbon 2002 Presidency, with less attention overall and less sharp peaks in media. Arguably, the 2002 Presidency was a milestone in the history of the European Union, while the results of the Presidency in 2012 were not as significant. However, the decline in media attention cannot be attributed only to the different outcomes of the Presidencies. The fact that these agreements were accomplished in and by Denmark clearly boosted media coverage in Denmark in 2002 more than in other countries. de Vreese (2005) has shown that media attention for the Copenhagen summit in 2002 was ten times larger in Denmark than in other countries. While European affairs were covered in 252 Danish television stories around the Copenhagen summit of 2002, on Dutch television there were only 25 stories about the EU in the same period (de Vreese, 2005). As the role of the political agenda-setter has become a less important aspect the Presidency post-Lisbon, it has become more difficult to generate such media coverage at home.

Institutional changes also affected media attention in other ways. The strengthened European Parliament had considerable influence on media attention for the 2012 Presidency. The presentation of the Presidency program by the presiding head of state in the EP led to broad media coverage and in the last three months of the Presidency, media attention peaked in the weeks when the EP met. In particular, in

${ }^{5}$ The Employment, Social Policy, Health and Consumer Affairs Council consists of ministers of the member states who are responsible for employment, social security, consumer protection, health and equal opportunities. 
June, the Parliament was in conflict with the Danish minister of Justice, which lead to wide coverage. The finding that the coverage of the Presidency is influenced by the agenda of the Parliament and conflicts between the Parliament and the Council shows that Danish media coverage of the Presidency clearly reflects the changing institutional powers in Europe. Secondary analysis of the topics discussed in relation to the two Presidencies (not shown) revealed that the creation of the new Foreign Policy coordinator also influenced the Danish media coverage. In 2002 the Danish minister of foreign affairs who represented the EU in relations with the United States received considerable coverage. In 2012, EU external affairs were hardly covered in relation to the Danish Presidency. This supports the conclusion that the institutional changes in the Presidency affected media interest for the EU Presidency at home.

We now turn our attention to the other two dimensions of media debate about the EU: inclusion and contestation. Despite the lower overall visibility than in 2002, the 2012 Presidency did generate the same amount of attention in the debate section of the newspapers. The Council Presidency was debated in 74 articles during the 2002 Presidency. This was almost as much in 2012 (see Table 1). ${ }^{6}$ Although the Presidency may have been less newsworthy, Danish editors of the opinion pages and contributors took the 2012 Presidency as an opportunity for debate about the EU.

Table 1

Debate about the 2002 and 2012 Presidency on the opinion pages of Jyllands Posten and Politiken ( $\%$ of opinion pieces in each category)

\begin{tabular}{|c|c|c|}
\hline & 2002 & 2012 \\
\hline Editorial & 26 & 4 \\
\hline Opinion piece/letter by Citizen & 23 & 3 \\
\hline Opinion piece/letter by Politicians & 20 & 29 \\
\hline Opinion piece/letter by Journalist & 7 & 11 \\
\hline Opinion piece/letter by Scholar & 4 & 11 \\
\hline Opinion piece/letter by Interest organizations & 5 & 29 \\
\hline \multirow[t]{2}{*}{ Opinion piece/letter of whom author could not be identified } & 15 & 13 \\
\hline & $\begin{array}{c}100 \% \\
(\mathrm{~N}=74)\end{array}$ & $\begin{array}{c}100 \% \\
(\mathrm{~N}=70)\end{array}$ \\
\hline
\end{tabular}

Nevertheless, the actors who contributed to debate in the newspapers changed considerably from 2002 to 2012. In 2002, more than one fourth of the articles on opinion pages about the Presidency were editorials, which reflects the broad media

${ }^{6}$ Only the opinion pages of the broadsheet newspapers Politiken and Jyllands Posten are included in this part of the analysis, since the tabloid newspapers included considerably less opinion pieces about the EU Presidency. 
attention and the prominence of the topic. In second place, just under one fourth of the opinion pieces and letters about the Presidency were signed by ordinary citizens, which reflects the high status of the Danish Presidency on the media agenda and public agenda at the time. In 2012 letters from the general public were strikingly absent of the media debate: only two letters from the public addressing the Danish Presidency were found on the debate pages. This is far less than the number of contributions from politicians, journalists and scholars. The largest increase in debate articles comes from interest organizations. In sum, the Danish Presidency in 2012 generated as much debate on the opinion pages of Danish broadsheets. However the voice of the general public, which featured prominently in 2002 was largely absent in 2012.

\section{Discussion: neutral and professional versus confrontational and engaging?}

The changing role of the Presidency of the European Union has had its impact on the media debate generated by the Presidency. In comparison to 2002, the 2012 Danish Presidency was less visible and less prominently covered. The different outcomes of the 2002 and 2012 Presidencies arguably had an influence on this, but the Lisbon Treaty is also an important part of the explanation. Institutional changes in the role of the Presidency introduced by the Lisbon Treaty clearly left their mark, such as the fact that the Presidency no longer chaired the meetings of the Council of heads of state or government. At the same time the parliament became a more prominent player, and had a strong impact on the media agenda about the Presidency. Although the total number of opinion pieces and letters to the editor equaled the numbers in 2012, this debate was less inclusive of ordinary citizens. According to the dimensions set out by Koopmans and Stratham (2010) this should be seen as a negative development for the ability of the media to contribute to the legitimacy of the European Union. Less visible and less inclusive coverage moves European politics further away from inclusive public politics in the direction of elite dominated debate. For a large part of the Danish audience the 2012 Presidency indeed seems to have gone by unnoticed. An opinion poll by the Danish public broadcaster showed that at the end of the 2012 Presidency one third of the voters answered "do not know" when asked to evaluate how Denmark handled the Presidency. This percentage was even higher among young voters and women (DR P1 Radioavisen, 2012). Where the pre-Lisbon Presidency was an opportunity to bring the EU closer to the citizens of the presiding country, this seems to be less the case now.

In its own evaluation of the Presidency, the Danish Government described itself as a "'tap water presidency' without grand gestures" (Danish Presidency, 2012b). In other evaluations of the presidency, the professionalism and neutrality in the way the Danish government handled the negotiations were highlighted (see Adler-Nissen, 2012; Gartner, 2012). Would the Danish government have taken a more confrontational approach and been more outspoken about its vision for Europe, this might 
have created more prominent debate about the role of the EU in Denmark and consequently more inclusion of and engagement with the general public. One of the few moments when the EU Presidency was prominently covered was when the Danish minster of justice was in conflict with the European Parliament. In other occasions however, the role as chair has seemed to limit the possibilities to be outspoken and generate debate at home. For example, in April 2012 minister of Justice Morten Bødskov did not want to give journalists insight into the views of the Danish government on the German-French proposal to reintroduce border controls, since it was his task to create a compromise among the EU countries (Kongstad \& Elbaek Maressa, 2012). Would the Danish government have been more outspoken, this could have triggered more debate at home about the current role and future of the EU. However being more outspoken has become more difficult post-Lisbon since it may compromise the Presidency's role of honest broker.

This relates to a broader challenge that national and European authorities face in their communication about the EU and its future. De Beus (2010:14) refers to this challenge as "the public sphere dilemma." When authorities facilitate more attention for and debate about the EU, this will not automatically lead to more public support, but might lead to poorer commitment and more critical attitudes in the short run. More media attention for the EU coverage might be provoked by a more confrontational communication style by the government, but this will often be accompanied with more critical citizens, more contestation, and more negativity (Boomgaarden et al., 2013).

Triggering a more intense debate about the future course of the EU by being more outspoken might compromise the role of the presiding country in European Union and may lead to conflict with the other members of the trio presidency. However, this might be a necessary evil if authorities want to use the platform of the Presidency to put the EU on the media and public agenda. In the long run this might be more effective than taking a neutral stand. In the words of Vivien Schmidt (2006:3), "were national leaders instead to engage their publics in deliberation in light of the new realities, they well might generate new legitimizing ideas and avoid the populist extremes, thereby enabling a clearer and 'truer' assessment of the EU's impact on national democracy."

\section{References}

Adler-Nissen, R. (2012), “Formandskabets prioriteter: Når EU’s Dagsorden bliver en National Ambition" [The Priorities of the Presidency: When the EU Agenda Becomes a National Ambition], Økonomi \& Politik 85(3), 4-14.

Beach, D. (2012), "Fremtidens Ledersløse Formandskab” [The leaderless Presidency of the Future], Økonomi \& Politik 85(3), 63-74.

Blach-Ørsten, M. (2012), “Pressen og EU-formandskabet” [The Press and the EU Presidency], Økonomi \& Politik 85(3), 51-62. 
Boomgaarden, H. G., de Vreese, C. H., Schuck, A. R. T., Van Spanje, J. H. P., Vliegenthart, R. (2013), "Across Time and Space: Explaining Variation in News Coverage of the European Union", European Journal of Political Research 52, 608-629.

Boomgaarden, H. G., Vliegenthart, R., de Vreese, C. H., Schuck, A. R. T. (2010), “News on the Move: Exogenous Events and News Coverage of the European Union", Journal of European Public Policy 17(4), 506-526.

Brüggemann, M., Kleinen-von Köningslöw, K. (2009), “Let's Talk about Europe: Why Europeanization Shows a Different Face in Different Newspapers", European Journal of Communication 24(1), 27-48.

Christensen, M. B., Nielsen, J. H. (2013), “Can a Small Non-Euro Member State Holding the EU Presidency Make a Difference in Times of EU Economic Crisis? Perspectives on the Danish EU Presidency", in: P. Dąbrowska-Kłosińska (ed.), Polish Yearbook of European Studies, YPES 15/2012, 88-105.

Danish Presidency (2012a), Europe at work; the Danish EU Presidency 2012, http:/ / eu2012.dk/ en/EU-and-the-Presidency/About-the-Presidency/ /media/Files/Trykt\%20materiale/ Brochure/EU_Presidency_Brochure_UK.pdf, accessed: September 5, 2013.

Danish Presidency (2012b), Europe at Work: The Results of the Danish Presidency of the Council of the European Union in the First Half of 2012, http://eu2012.dk/en/NewsList/Juni/ Uge-26/The-Presidencys-achievements, accessed: September 5, 2013.

Danish Presidency (2012c), What is an EU Presidency?, http://eu2012.dk/en/EU-andthe-Presidency/About-the-Presidency/Hvad-er-et-EU-formandskab, accessed: September 5, 2013.

De Beus, J. (2010), “The European Union and the Public Sphere: Conceptual Issues, Political Tensions, Moral Concerns, and Empirical Questions", in: R. Koopmans and P. Strathman (eds), The Making of a European Public Sphere; Media Discourse and Political Contestation, Cambridge: Cambridge University Press, 13-33.

de Vreese, C. H. (2005), “The Spiral of Cynicism Reconsidered”, European Journal of Communication, 20, 283-301.

de Vreese, C. H., Banducci, S. A., Semetko, H. A. and Boomgaarden, H. J. (2006), “The News Coverage of the 2004 European Parliamentary Election Campaign in 25 Countries", European Union Politics 7, 477-504.

Dr P1 Radioavisen (2012, 28 June), “En trejdedel kan ikke vurdere EU-formandskab" [One third cannot evaluate the EU-Presidency]. DR P1 Radioavisen 06.00 (resumé).

European Commission (2006), White Paper on a European Communication Policy, Brussels: DG Press and Communication.

Fischer, C. (2002, 2 August), “Debat: EU-formandskab: Navlebeskuende Mediedækning” [Debate: EU Presidency: Self-Centered Media Coverage], Politiken, 5.

Friis, L. (2003), “The Danish Presidency: Wonderful Copenhagen”, Journal of Common Market Studies 41, 49-51.

Gartner, A. (2012), “A Professional, Pragmatic Presidency”, European Voice, 5 July.

Hix, S. (2008), What's Wrong with the European Union \& How to Fix It, Cambridge: Polity.

Kongstad, J., Elbaek Maressa, J. (2012, 21 April), “Tyskland hjælper Sarkozy i strid om grænsekontrol" [Germany helps Sarkozy in fight over border control], Jyllands-Posten, 14.

Koopmans, R. and Stratham, P. (eds) (2010), The Making of a European Public Sphere; Media Discourse and Political Contestation, Cambridge: Cambridge University Press. 
Lindberg, L., Scheingold, S. (1970), Europe's Would-Be Polity, Englewood Cliff, NJ: Prentice-Hall.

Machill, M., Beiler, M. and Fischer, C. (2006), “Europe-topics in Europe's media. The debate about the European public sphere: a meta-analysis of media content analyses", European Journal of Communication 21(1), 57-88.

Manners, I. (2013), “The 2012 Danish Presidency of the Council of the European Union: Bridging Exclusion", Journal of Common Market Studies 51, 70-79.

Meyer, C. O. (2005), “The Europeanization of Publicised Debates: A Study of Quality Press Coverage of Economic Policy Coordination since Amsterdam", Journal of Common Market Studies, 43:1, 119-46.

Norris, P. (2000), A Virtuous Circle: Political Communication in Postindustrial Societies, Cambridge: Cambridge University Press.

Peter, J., de Vreese, C. H. (2004), “In Search of Europe. A Cross-National Comparative Study of the European Union in National Television News", Harvard International Journal of Press/Politics 9(4), 3-24.

Schmidt, V. A. (2006), Democracy in Europe. The EU and National Polities, Oxford: Oxford University Press.

Van Noije, L. (2007), The Democratic Deficit Closer to Home, Amsterdam: Vrije Universiteit.

Wahl-Jorgensen, K. (2002), “Understanding the Conditions for Public Discourse: Four Rules for Selecting Letters to the Editor", Journalism Studies 3(1), 69-81. 
Part III

Media on the Polish EU Council Presidency 

Romy Wöhlert

Austrian Academy of Sciences

\& Alpen-Adria-University Klagenfurt, Vienna, Austria

\section{Struggling for Visibility in Times of a Family Crisis. The Perception and News Coverage of the Polish EU Presidency 2011 in Germany and Austria}

\section{Introduction}

Does the EU presidency offer the potential for the country holding this position to change its image among the other member states of the European Union? Against the background of this question, this chapter summarizes the key features of the German and the Austrian print media news coverage on Poland throughout the timeframe of the Polish EU presidency term in 2011. Taking a comparative look at the German and the Austrian media perception of the Polish EU presidency is thereby guided by two assumptions: (a) the differences and similarities in the bi-national relations of both countries with Poland may have an impact on the media perceptions of Poland in the context of the event focused, and (b) the self-perception of both countries with regard to their own membership in the EU as a collective entity may also shape the perception of the Polish EU presidency and of Poland as another member of this collective group. It is especially the second aspect that may be most relevant when we come to explain the focus (or the lack of the same) both countries put on Poland and its performance during the Polish EU presidency and the media images and evaluations that result from it.

\section{Theoretical background and hypotheses}

Foreign news coverage presents a central platform for international and communication processes, because international relations issues such as EU-related matters are essentially second-hand reality to most people. They form a rather abstract and distant level of relations that people do not have direct access to. Therefore, foreign media news coverage can significantly shape the knowledge that people have of other countries and cultures (Hargrove \& Stempel, 2002; Wanta et al., 2004). In addition to that, the exposure to foreign news can have an impact on attitudes and opinions concerning foreign countries (Semetko et al., 1992).

Thus, for a country the task of image politics, i.e. the ability to be in charge of the construction and projection of a prestigious or powerful self-image, can be regarded 
as important as a country's political, economic and military strength and performance (Gilboa, 2004). Consequently, countries also strive for internationally higher visible and positive world images (Kunczik, 2003). As Stępińska (2013) has pointed out, therefore governmental public diplomacy increasingly resembles corporate public relations strategies or global branding campaigns to attract media attention and influence other countries' public opinion - one aim here being to affect foreign governments, tourism, and corporate investment (Rivenburgh, 2010; Signitzer \& Coombs, 1992).

However, studies (see, for instance, Galtung \& Ruge, 1965; Ostgaard, 1965; Shoemaker \& Cohen, 2006; Staab, 1990; Weber, 2010; Wilke et al., 2012; Wu, 2000) have shown that everywhere in the world, foreign news coverage concentrates mainly on events that are geographical or culturally close to a country. Following Stępińska (2013), based on those studies we assume that the news coverage of foreign countries hosting certain international political events depends on the proximity (or distance) between observing and observed country, as well as on their cultural, political or economic relations. The keyword here is the level of bi-national relations between observing and observed country: We assume that the smaller the geographical, but also political, economic, and social distance, the more complex is the picture of the country in the media (i.e., the more topics and events are covered by the news media).

A second keyword is EU relations and status. We assume that the EU as a transnational collective entity is another relevant context factor defining the reciprocal perceptions of countries within this union, particularly when it comes to the performance in an official EU position. Here, the status of the (EU) members in the collective group is regarded as relevant, what status the observed country is ascribed with, and how the observing country relates to the (EU) group and its own status in it. For instance, if Austria is unhappy with its own status in the EU, this may also affect the Austrian perception of Poland and its presidency performance.

With regard to intra-EU relations and its impacts on reciprocal media news coverage, numerous media studies have been conducted in the last two decades: Some of them were devoted to analyze the media coverage of major European events; others studied the contribution of the press to a Europeanization of the public sphere (see, for instance, de Vreese \& Semetko, 2004; Maier et al., 2012; or Wilke \& Reinemann, 2007). Many studies on the news coverage of EU affairs generally focus on the EU as an intergovernmental institution, but largely remain ignorant of the particular flows of news in between the member states of the EU. Also, most of those studies focused either on short-duration events or long-term relations between the EU institutions (Trenz, 2004), only had a national scope (Ekengren 2004; Quagllia, 2006), or looked at media, public opinion and the process of the EU integration, while less attention is paid to a single country performance over a certain time period. For Poland, Stępińska (2013) pointed out that studies mainly focus on the timeframe before Poland's accession to the EU in 2003. Results showed that Po- 
land had a very low level of media visibility and recognition, but was overall presented like other EU countries.

Based on the outlined theoretical observations and the state of research, our study focused on the comparative analysis of the news coverage of the Polish EU presidency 2011 in two other EU member states, Germany and Austria. We thereby focused on two central aspects: (a) the differences and similarities in the bi-national relations of both countries with Poland and the impact of those relations on the media perceptions of the country in the context of the EU presidency news coverage; and (b) the self-perception of both countries with regard to their own membership in the EU and the effects this self-perception on both countries' perception and evaluation of another EU member state.

This chapter will introduce results of the qualitative content analysis of our study, taking into view news items that reported on Poland in relation to the EU presidency, in order to identify how visible Poland was in the context of this news coverage, how complex the country was portrayed in that context, and how the Polish EU Presidency performance was evaluated. ${ }^{1}$ We thereby applied the following research questions to analyze the German and Austrian news coverage:

RQ1: How visible is Poland in the German and Austrian news coverage of the Polish EU Presidency?

RQ2: How complex is the German and Austrian news coverage of Poland in the context of EU Presidency-related articles?

RQ3: How are Poland and the Polish performance as holder of the EU Presidency evaluated in the German and Austrian news coverage of the EU Presidency?

This paper will outline the major findings on those three questions, and will come up with a brief contextualization and interpretation of the results against the background of the national self-perception of both Germany and Austria as EU members, as well as both countries' bi-national relation with Poland.

\section{Data sample and methodology}

Following the two theoretical aspects pointed out before, it is assumed that we have to consider two influences as important when we analyze the news attention and qualitative perception that other EU countries apply to Poland in the timeframe of its EU Presidency: (1) bi-national relations between Poland and the perspective observing country, and (2) the status and relations of the observing country with the EU. Looking at Germany and Austria, we expected the news coverage to differ to some extent (but not completely) for the following reasons:

\footnotetext{
1 For a summary of the quantitative aspects of the news coverage and the overall news coverage on Poland in general - see Wöhlert (2013a, 2013b) and Stępińska (2013).
} 
Regarding (1) the bi-national relations, both countries are geographically close to Poland, have close economic ties, and a long history of bi-national political relations with the country. Germany has a special and not always conflict-free relationship to its neighboring country Poland. ${ }^{2}$ As Gatzke (2010) agues, the German perception of Poland can be described with to two crucial terms that form two ends of a continuum: admiration and rejection. With regard to EU and international relations, both countries faced conflicts over support for the 2003 Iraq War (Poland was pro-war, Germany against the military intervention), as well as in the debate over the EU constitution and the weight of EU country votes (Gatzke, 2010; Ociepka et al., 2008; Szarota, 2010). Austria and Poland also share a history of relation, ${ }^{3}$ and due to the shared experience of having been a victim of German Nazi occupation, Poland was long perceived as an ally, and after 1945 the relationship of Communist Poland to the neutral Austria was better than to most other Western states in Europe. This close relationship has remained until today. Austria also has a large community of Polish immigrants, most of whom came to Austria in the course of the internal political conflicts in Poland and the worsening economic conditions in the 1980s (Potkanski, 2011).

Regarding (2) the relationship with the EU, Germany, on the one hand, is one of the founding members of the EU, and also one of the "EU-heavyweights" regarding its population size and its political standing. Furthermore, the country has a rather supportive position towards its own EU membership as well as to EU-related matters. This position was slightly shaken more recently by the EU financial crisis, but remains more positive still than in many other EU countries (Risse-Kappen, 2010). Austria, on the other hand, entered the EU only in 1995. It is also one of the "EU-lightweights" regarding its population size but also its political status. Also, since its accession the country has developed a rather ambivalent and skeptical position towards its own EU membership and EU-related matters, which may also reflect in the Austrian news coverage on the Poland EU presidency (Brantner, 2009; Vitouch \& Mayer, 2004).

Comparing the two countries also allows us to see whether or not those two context factors lead to differing perceptions of Poland's EU presidency performance, and whether Poland's public relations efforts to perform great and change the own country's image in the context of the presidency term are thwarted by (bi)-national or EU-related sentiments.

\footnotetext{
2 Ranging from the military attack by Nazi Germany in the Second World War, to the subsequent violent displacement of Germans from the Polish territories, the policy of détente after the breakdown of the Eastern European Communist regimes, the recent conflicts over compensation claims of German displaced people (2nd World War), and the 2005 election campaign of the later Polish President Lech Kaczyński in 2005, which fueled anti-German resentments in Poland (Asmuss \& Koch, 2009)

3 Ranging from military conflicts on the periphery of both the Holy Roman Empire and the Habsburg Monarchy in the $15^{\text {th }}$ century, the military cooperation during the threat by the Ottoman Empire, the defeat of the Ottomans outside of Vienna by Polish king John III Sobieski in 1683 (Leitsch \& Trawkowski, 1993, 1997).
} 


\section{German and Austrian media samples}

The results presented here stem from a quantitative and qualitative content analysis of Germany and Austrian print media that were analyzed over a timeframe of 7 months, between 15 June 2011 and 15 January 2012, focusing on the core periods [1] 15 June - 31 July 2011, [2] 01 September - 15 October 2011, and [3] 01 December 2011 - 15 January 2012. The German sample included two daily quality newspapers (Frankfurter Allgemeine Zeitung, Süddeutsche Zeitung), the daily tabloid newspaper (Bild), and the weekly news magazine (Der Spiegel). For the Austrian country case, the sample also included two daily quality newspapers (Die Presse, Der Standard), the daily tabloid newspaper (Kronenzeitung), and the weekly news magazine (Profil). The analyzed media for each country are nationally available and have the largest distribution rates (Hans-Bredow-Institut für Medienforschung, 2009).

All articles were searched ${ }^{4}$ and acquired from online databases and were saved as digital files (PDF format). We used the digital archives of the FAZ and SZ, the general digital archives Press Display and wiso Presse (accessible via the Austrian National Library), and the Mikrofilmarchiv in Dortmund for the tabloid Bild. For each newspaper/weekly magazine and analyzed publication day, the whole newspaper edition was searched and all journalistic materials were included. If a newspaper had Sunday editions, those were also included in the analysis. We did not include "local" news articles in the sample, if those local sections vary between the local editions of newspapers. We only included articles in the qualitative content analysis when the reference to the Polish EU presidency was explicitly made, to allow for comparability of the two country samples.

\section{Methodology of the qualitative content analysis}

To specify the news perception of Poland in EU presidency-related content, based on the overall research questions and theoretical assumptions, we defined three structuring dimensions that aim to identify and categorize relevant information in the news articles (following Mayring, 2003:82-83). As Nawratil and Schönhagen (2008:339-346) point out, this allows for a systematic structuring and summarizing of the material based on predefined criteria. Derived from the theoretical considerations and the guiding research questions defined earlier, the three analytical dimensions were subsequently operationalized into three core structuring categories for the qualitative content analysis we carried out for the news articles. For each category a set of deductive analytical questions was used to identify the relevant content in the news texts (see Table 1).

\footnotetext{
4 To identify relevant articles and based on the project instructions, we used the search keywords "Polen", "Polens", "Pole", "Polin", "Polinnen", "polnisch", "polnische", "polnischer," "polnisches", "polnischem", and "polnischen".
} 


\section{Structuring categories and analytical questions for the qualitative content analysis}

\section{Category 1: VISIBILITY}

Definition: This category aims at identifying the overall visibility of both EU presidency and Poland in the analyzed samples, to lead to a better understanding of the actual importance of Poland in the news coverage.

\section{Analytical questions:}

1. Is the EU presidency and/or Poland a central or minor topic of the news article?

2. How is the overall appearance of the news article, i.e. what size does the article have, and does it also include visual elements?

\section{Category 2: COMPLEXITY}

Definition: This category aims at defining the complexity of views on Poland in the context of EU presidency-related content as provided in the two analyzed samples, in order to define the qualitative relevance and visibility of Poland in the news coverage.

\section{Analytical questions:}

1. What Polish actors present their views or comment on EU presidency-related topics in the news coverage?

(i.e., how many opportunities were given to Polish actors to present Polish standpoints in the context of the news coverage on the EU presidency and on what specific aspects)

2. What non-Polish actors present views or comment on EU presidency-related topics in the news coverage?

(i.e., how many opportunities were given to non-Polish actors to present their views on the discussed topics and/or the Polish presidency performance)

3. What additional statements on Poland or Polish actors are provided in the respective articles?

(i.e., how much attention is paid to Poland and Polish actors beyond EU presidency-related topics, and what facets are focused)

\section{Category 3: EVALUATION}

Definition: This category aims at defining how Poland is perceived and evaluated during its presidency term, either in its performance as holder of the EU presidency or beyond that.

\section{Analytical questions:}

1. How do Polish actors quoted in the news coverage evaluate the Polish EU presidency performance?

2. How do non-Polish actors quoted in the news coverage (or the news media themselves) evaluate the Polish EU presidency performance, and do those "external" non-Polish evaluations differ from the "internal" Polish ones?

3. How is Poland evaluated beyond its EU presidency performance?

As Mayring (2003:92-95) defines it, Category 1 presents a scaling structuring (skalierende Strukturierung) that defines scale points for the dimension visibility, according to which the news articles were sub-classified. Categories 2 and 3 allowed for a content structuring (inhaltliche Strukturierung) that extracted certain parts of the overall news content and summarized it focusing on our outlined research ques- 
tion. By structuring the content of the articles based on those deductive categories we were, on the one hand, able to reduce the complexity of the diverse articles to the key questions we wanted to answer in this study. On the other hand, the method allowed better comparison of the two country samples. ${ }^{5}$

\section{Visibility of Poland in the German and Austrian news coverage of the EU-Presidency}

Altogether, we identified 795 newspaper articles in the analyzed Austrian print media for the focused on time frame, and 1,353 news items in the German print media. As Table 2 outlines, additional references to the EU presidency were only identified in 74 of the German and 57 of the Austrian articles. Distinguishing between the time periods before, during and after the Polish EU presidency term, we saw that the share of the overall publication output did not change significantly with the beginning of the presidency term on July 1, 2011. Rather the opposite effect was observed: In both countries, the share was highest in the pre-presidency period. ${ }^{6}$

Table 2

German and Austrian data samples

\begin{tabular}{||l|c|c||}
\hline & Number of articles & Percentages $^{7}$ \\
\hline German print media sample & $1,353\left(74^{*}\right)$ & $100(5.5)$ \\
\hline Austrian print media sample & $795\left(57^{*}\right)$ & $100(7.2)$ \\
\hline
\end{tabular}

* Articles with References to Poland AND EU Presidency.

Thus overall, the news attention towards Poland in the context of the EU presidency function has not significantly increased with the country's takeover of the position. Also, the results indicate that both countries' overall media perspective on Poland was not centrally shaped by this role; over 90 percent of articles did not relate to it when taking Poland into view. Furthermore, in both Germany and Austria, we also identified longer phases (e.g., in December 2011) with almost no news coverage on the EU presidency when Poland was taken into view. However, a simple counting of articles does not fully tell us whether or not the German or Austrian news coverage actually focused on EU presidency and Poland in particular when both terms appeared in a news item. To define this visibility, we need to look at the articles' content a bit closer.

5 The analysis was carried by two coders. To test the intercoder reliability, we let both of them analyze 10 articles based on the outlined analytical questions as a pre-test of the analysis. We used the Holsti Reliability formula and measured a Holsti's coefficient of 0.886 . We repeated the test after completion of the analysis and measured a congruence of 0.843 .

${ }^{6}$ For a more detailed analysis of quantitative aspect, see Wöhlert (2013a, 2013b).

7 Percentages refer to the share of the overall sample. 
Is the EU Presidency and/or Poland a central or minor topic of the news articles?

To better define the actual visibility of Poland in the German and Austrian news coverage related to the EU presidency also allows us to gain a better idea of whether or not Poland actually received more attention due to the EU presidency term, or whether it remained a side-kick actor in the news content referring to the EU presidency. Articles in the Germany and Austrian news coverage could be distinguished into four levels of relevance.

Table 3

Relevance of Poland and EU Presidency in news articles

\begin{tabular}{|l|c|c|c|c||}
\hline \multicolumn{1}{||}{ Relevance for articles } & Total & $\begin{array}{c}\text { Pre- } \\
\text { presidency }\end{array}$ & $\begin{array}{c}\text { During } \\
\text { presidency }\end{array}$ & $\begin{array}{c}\text { Post- } \\
\text { presidency }\end{array}$ \\
\hline German print media & \multicolumn{5}{|c|}{} \\
\hline 1 Poland and EU presidency & 16 & 3 & 13 & 0 \\
\hline 2 Presidency & 4 & 1 & 0 & 3 \\
\hline 3 Poland & 16 & 4 & 10 & 2 \\
\hline 4 none & 38 & 2 & 36 & 0 \\
\hline Austrian print media & 13 & 2 & 11 & 0 \\
\hline 1 Poland and EU presidency & 8 & 1 & 2 & 5 \\
\hline 2 Presidency & 14 & 3 & 11 & 0 \\
\hline 3 Poland & 21 & 2 & 19 & 0 \\
\hline 4 none &
\end{tabular}

* Number of articles.

(1) Both the EU presidency and Poland are a central focus of the article. In those articles, the central focus was put on Poland in its role as presidency holder. Altogether, we find only 13 articles in the Austrian sample and 16 in the German one that have this major focus, most of those being published in the time frame during the Polish EU presidency term, while after the end of the term, none of those articles was identified.

(2) The EU presidency is a central focus of the article, but Poland is only a minor focus. In those articles only the presidency itself received major attention, while Poland remained only a side note. Other issues (or other countries of the EU such as France, Greece or Germany) superposed the presidency news coverage, and Poland was only mentioned as the current holder of the presidency. For the strategic ambition of gaining more attention from international media throughout the presidency term, those articles would indicate that Poland was not successful in its attempt to perform and sell itself in this position. However, only few articles in both country samples fall into this set, the majority of which appeared after the end of the presidency term. In those articles, Poland was indeed only a side note, since the presi- 
dency topic was now connected to the next country of the rotation principle (Denmark).

(3) The EU presidency is a minor focus of the article, but Poland is the major focus. Those articles suggest that an increased attention is indeed granted to Poland, but other topics are more important in that context, while the EU presidency may just be the trigger for the attention paid towards on Poland. Opposite to that, it could mean also that Poland did not succeed to move beyond the topic that is focused on, despite being the holder of the EU presidency. In both country samples, those articles were medium-frequent; most of them we identified during the presidency term.

(4) Both the EU presidency and Poland are only a minor focus in the article. Articles of this set revealed to have only a minor focus on both Poland and the EU presidency, and instead focused on other topics, referring to both mentioned aspects only in a side-line. This was the case in a large number of articles of the German and the Austrian sample, most of which were in addition found in the timeframe during the Polish EU presidency. It supports the overall observation already made by Wöhlert $(2013 a, 2013 b)$ that the Polish EU presidency was not a topic of interest for the German and Austrian news coverage, and that Poland's views and actions were - at least to a significant extent - not visible in the German and Austrian perception.

How is the overall appearance of the news articles?

But did the articles actually "catch the reader's eye," due to their size or because they included one or more visual images (e.g., pictures, graphs) that may catch the attention of readers and would make Poland as content of the article more visible? Table $4 \mathrm{a}$ lists the categorization of all articles with regard to their size, while Table $4 \mathrm{~b}$ categorizes them according to the visual image use.

Table 4a

Sizes of articles

\begin{tabular}{|l|c|c|c|c||}
\hline \multicolumn{1}{|c|}{ Size of articles } & $\begin{array}{c}\text { Short news } \\
\text { (3-4 sentences) }\end{array}$ & $\begin{array}{c}\text { Quarter of } \\
\text { page or less }\end{array}$ & Half a page & $\begin{array}{c}\text { More than } \\
\text { half a page }\end{array}$ \\
\hline German print media & $12^{*}$ & 43 & 14 & 5 \\
\hline Austrian print media** & 9 & 28 & 14 & 4 \\
\hline
\end{tabular}

* Number of articles.

** For 2 articles size not identifiable due to database problems.

The majority of the German and Austrian articles only filled about a quarter of the respective newspaper page or less, but we also found a number of bigger articles, filling half a page or even more space. However, one has to note here, that arti- 
cles that could be considered as most relevant for our research interest - those that put a central focus on Poland, the EU presidency, or even both aspects - were less frequent and smaller in size. The medium and larger-sized articles often did not have a central focus on Poland and/or the EU presidency, and often only briefly mentioned the topic/country in a side note. Given that notion, the appearance of Poland in the context of the EU Presidency topic was rather invisible.

Table $4 \mathrm{~b}$

Visual image use

\begin{tabular}{|l|c|c|c|c|c|}
\hline $\begin{array}{c}\text { Use of visual } \\
\text { images }\end{array}$ & $\begin{array}{c}\text { One image } \\
\text { with Polish } \\
\text { reference }\end{array}$ & $\begin{array}{c}\text { Several images } \\
\text { with Polish } \\
\text { reference }\end{array}$ & $\begin{array}{c}\text { One image, } \\
\text { but no Polish } \\
\text { reference }\end{array}$ & $\begin{array}{c}\text { Several images, } \\
\text { but no Polish } \\
\text { reference }\end{array}$ & $\begin{array}{c}\text { Only } \\
\text { text }\end{array}$ \\
\hline $\begin{array}{l}\text { German print } \\
\text { media }\end{array}$ & $14^{*}$ & 2 & 8 & 0 & 50 \\
\hline $\begin{array}{l}\text { Austrian } \\
\text { print media** }\end{array}$ & 7 & 2 & 13 & 0 & 21 \\
\hline
\end{tabular}

* Number of articles.

** For 13 articles information on visual images was not provided by the used databases.

The visibility of Poland also is not additionally supported by visual "eye-catchers" in the respective articles. As Table $4 \mathrm{~b}$ shows, a large number of articles in both country samples did not include any visual images (in the German sample almost $75 \%)$, or only images that had no references to Poland.

\section{Complexity of German and Austrian news coverage on Poland in EU Presidency-related articles}

To gain more insights into the way in which Poland was perceived in the analyzed German and Austrian articles, in a second step we identified the complexity of the Polish image in the context EU presidency-related news material, by answering three questions:

What Polish voices on EU Presidency-related topics are presented in the news coverage?

Our analysis showed that the variety of Polish actors that were provided space in the German and Austrian news coverage to give statements on EU presidency-related topics indicated that those voices were limited to the political level. Also, most of those statements were identified in the timeframe during the Polish presidency term and were made by Polish politicians (Table 5). 
Table 5

\section{Polish voices on the EU Presidency in German and Austrian print media}

\begin{tabular}{|l|l|}
\hline \hline German print media \\
\hline Political actors & $\begin{array}{l}\text { Polish Prime minister Donald Tusk; Polish President Bronisław } \\
\text { Komorowski; Polish Minister for European Affairs Mikołaj Dowgie- } \\
\text { lewicz; Polish diplomats n.n.; Polish Minister of Finances Jacek Ros- } \\
\text { towski; Polish Minister of Agriculture and Rural Development Marek } \\
\text { Sawicki; Polish Minister of Economy; Waldemar Pawlak; Polish oppo- } \\
\text { sition leader Jarosław Kaczyński }\end{array}$ \\
\hline Civil society actors & Polish news media \\
\hline Austrian print media \\
\hline Political actors & $\begin{array}{l}\text { Polish Prime minister Donald Tusk; EU Secretary Adam Jasser; Polish } \\
\text { President Bronisław Komorowski; Polish Parliamentarian n.n.; Polish } \\
\text { Senate; Likas Abgarowicz; Polish Minister of Justice Krzysztof Kwiat- } \\
\text { kowski; Polish host of meeting Mikołaj Dowgielewicz; Spokesman Pol- } \\
\text { ish EU Presidency; former Polish President Aleksander Kwaśniewski }\end{array}$ \\
\hline Civil society actors & $\begin{array}{l}\text { N.N. expert, Director Polish Institute for International Affairs, Marcin } \\
\text { Zaborowski; Private person with Polish origin (Letter to the editor) }\end{array}$ \\
\hline
\end{tabular}

Most often quoted was the Polish Prime Minister Donald Tusk, not only because he gave the introductory speech on the Polish presidency term, which was discussed in the news coverage, but also because in formal meetings on the EU level, he was one of the main representatives of Poland as the holder of the EU presidency. In the German media, Tusk was accompanied more frequently by other Polish political officials than in the Austrian media, leading to a more complex political spectrum of voices being noticed in the German perception. To a minor extent, both German and Austrian perspectives also included voices from Polish civil society. In Germany, this included mainly the reporting media itself stating views on Polish-related matters, while in Austria also other civil society actors were quoted.

The topic most often commented on by Polish actors in both the German and Austrian sample was the European economic and financial crisis. This is obvious since Poland fulfilled the role of an official spokesperson for EU matters during its presidency term, and it was mainly in that context that Polish officials were quoted (during EU meetings or after EU agreements etc.). Other EU-related topics Polish actors commented on in both samples were EU foreign relations (among EU member states), the EU enlargement topic (focusing in German media mainly of the negotiations of Ukraine, in Austrian those of Croatia), the general current situation and state of the EU, the EU budget cohesion fond, the (future) Polish membership in the Eurozone, Polish-German cooperation on EU matters (in the German media), or the (foreign) EU policy of Austria (in Austrian media). Also addressed was the Polish definition of Europe, a topic that came up because Tusk significantly focused on it in his inauguration speech. In both samples, most of those statements were identi- 
fied in the timeframe during the EU presidency, and we overall noticed a slightly increased complexity of Polish voices during the presidency term, even though the voices presented often came from re-occurring actors and not a broad range of different actors. Thus, from our observation we may conclude that the EU presidency did lead to a slightly more complex perception of Poland in the German and Austrian media appearance.

What non-Polish voices on EU Presidency-related topics are presented in the news coverage?

In both country samples we also found non-Polish voices in the analyzed articles (Table 6).

Table 6

Non-Polish voices addressing the Polish EU-Presidency performance

\begin{tabular}{|l|l|}
\hline \hline German print media \\
\hline Political actors & $\begin{array}{l}\text { Former president Richard von Weizsäcker, Dalai Lama; Politicians in } \\
\text { Brussels n.n. }\end{array}$ \\
\hline Civil society actors & $\begin{array}{l}\text { German and international news media; private person (letter to the } \\
\text { editor); and South African Archbishop Desmond Tutu }\end{array}$ \\
\hline Austrian print media \\
\hline Political actors & EU parliamentarians \\
\hline Civil society actors & $\begin{array}{l}\text { German Environmentalist group, political expert/observer, private } \\
\text { person (letter to the editor); Austrian news media themselves }\end{array}$ \\
\hline
\end{tabular}

However, we noticed that altogether the Polish role as EU president is not a central focus in many articles. Therefore, only few quotes were identified in those articles that commented on the Polish performance, while most statements we identified addressed other EU-related topics (see section 5.1.), and here most prominently the ongoing negotiations (e.g., bi-national meetings, EU summits etc.) in order to solve the Eurocrisis. In the context of this news coverage, Poland was mostly a side-kick to the actual debates, and most prominently EU "heavyweights" such as Germany, France and Great Britain, or countries affected by the crisis, like Greece or Spain, were commented on. Comments on the Polish performance mainly came from the reporting news media themselves.

When we compare the variety of non-Polish actors providing views with those of Polish actors, we see that the presentation was rather balanced. In both areas political actors were most often quoted, which is not surprising, because EU presidency-related topics are usually located on a political level, and thus presented and observed by actors from the political sphere. All in all, Polish voices were as complex as the non-Polish, and thus successfully made it into the news content, where 
Polish (political) actors presented their views on the EU presidency position and its tasks.

What additional statements on Poland or Polish actors are given in the news coverage of EU Presidency-related topics?

The third question aimed at identifying how much attention was paid to Poland beyond the topic "EU presidency" and what facets were taken into view here. For both German and Austrian print media, our analysis revealed that indeed also other aspects were reported on with regard to Poland in the context of EU presidency-related articles. A major additional focus in both country samples was put on Polish national peculiarities. Here, statements related to or gave insights into the political situation in Poland (especially referring to the Polish national Parliamentary elections that took place in September 2011), the Polish communist past, the Polish economic situation, or Polish environment politics. Additionally, Poland was also perceived with regard to its international/bi-national relations, e.g. with Germany (in the German media), with Austria (in the Austrian media), or with non-EU neighboring countries (especially Ukraine, observing the Polish positions in EU-negotiations with the country; a topic mainly focused on in German news media).

Thus, beyond the EU presidency and related topics, we found a broader and slightly more complex observation of Poland in the context of some of the articles in both country samples. The overall image and perception of Poland was not solely one-dimensional, i.e. focusing only on the EU political level, but also, Polish voices on EU topics and beyond were found in the German and Austrian news coverage. Throughout the presidency term, both the German and Austrian perception of Poland was complex, even though this complexity did not necessarily increase with the beginning of the presidency term. Also, the strong focus on Polish national issues during the presidency may have been caused by the national Parliamentary elections that took place in Poland in September 2011. Thus, our observations should be compared with other timeframes to decide whether the identified complexity is an effect of the EU presidency position or not.

\section{Evaluation of Polish EU Presidency and Poland in EU Presidency-related articles}

Last but not least, in order to identify whether or not the Polish EU Presidency term helped the country to present itself successfully as a competent and important EU actor on the European political arena, we took a closer look at the way in which both German and Austrian print media evaluated the country, in general and with regard to its performance as holder of the EU Presidency. The identification of this media evaluation allows for a conclusion on whether or not the country's ambitions to 
use the presidency term to enhance the own national image in the EU were successful. Here, again three questions were analyzed:

How do Polish actors in the news coverage evaluate the Polish EU Presidency performance?

The integration of the Polish perspective in the overall news coverage indicates whether German and Austrian media offer its readers a broad spectrum of evaluations on that question, thereby including also the position of the EU presidency holder. This self-observation becomes interesting when we compare it in the next section with the external evaluations provided by non-Polish voices. With this comparison we can reveal, whether Poland may be perceived as a "realistic observer of EU politics" or whether its own perspective deviates significantly from that of the other EU members, indicating that the country might not have reached the level of political skills needed to observe and implement EU politics successfully.

In the German news coverage, the quoted Polish actors evaluated the own EU presidency term predominantly neutral or positive, especially in the beginning of the term. Poland defined itself as pro-European, and the major ambitions pointed out frequently by Polish actors were to unify the EU again in light of the disputes over the Eurocrisis and to secure the political stability of the union. Poland offered itself to be the spearhead for leading the EU through this crisis during its presidency term. Another central topic was the European relation with Ukraine. ${ }^{8}$ Overall, the Polish self-presentation in the news coverage was ambitious and very engaged in European issues.

Also in the Austrian news coverage, quoted Polish actors evaluated the own EU Presidency term predominantly neutral or as a success. A number of the given quotes referred to the function and the actual "power frame" that the position offers for its respective holder. As in the German news coverage, in the beginning of the term, Polish actors were committed to and enthusiastic about the presidency, but we also found statements expressing slight hesitance and humbleness with regard to the tasks that the country will face. Voices also argued that Poland knows that it will not be able to "change the world" in the six months of its presidency term. During the term, quoted Polish voices stayed enthusiastic but also slightly more realistic and pragmatic with regard to the position, doubting that the own set goals are all achievable. Polish views and concluding evaluations towards the Polish presidency term were not identified in the German and Austrian news coverage.

8 The country struggled with internal political turmoil over the arrest and law suits against the politician Timoschenko at that time, which was highly criticized by the EU; here Poland saw itself as an inter-mediator between both sides. 
How do non-Polish actors in the news coverage evaluate the Polish EU Presidency performance?

Non-Polish voices in the German news coverage were slightly more critical in their evaluation of the Polish EU presidency performance than in the Austrian news coverage, which reflected a more neutral and distant perception. Altogether, voices in both country samples were predominantly identified during the presidency term, mainly in the beginning, in German print media also towards the end of the presidency term.

In both country samples, in the beginning of its term, Poland was perceived as ambitious and self-confident in its position, and was praised in particular for its self-acclaimed goal to use its presidency term to re-unite the union in view of the Eurocrisis and the political as well as economic disputes that have arisen from this crisis. Based on the inauguration speech of Polish Prime Minister Tusk, which was very well received, Poland was also positively perceived for its self-acclaimed "commitment to Europe" and for its diplomatic and pragmatic approach as current holder of the EU presidency, especially in times of political and economic turmoil causes by the Eurocrisis. In both country samples, Poland was portrayed as being un-agitated and realistic in its evaluation of its own capacities to carry out the set tasks and achieve the own goals. However, it was also mentioned that the country faces difficult tasks, and that despite being self-confident, Poland is a rather powerless and insignificant political player in the EU arena.

This view was increasingly adapted throughout the presidency term. In the Austrian newspapers, voices more frequently pointed out that Poland faces a difficult tasks (especially because of the Eurocrisis). It was increasingly doubted that the country would be able to achieve all its goals set to achieve in its own presidency term. In the German sample, this perspective was also adapted, even though voices and views presented here also pointed out that the country acts rather tactically based on its own interests that are not always compatible with EU interests (or even more so, with interests of the "major EU players" such as Germany, France, or UK). The major EU topics referred to here were EU environment politics (here a dispute was seen between the German and the Polish position), or the EU negotiations over the Stability and Growth Pact. Concluding evaluations towards the end the Polish presidency term were that Poland is a rather powerless EU member state and its impacts were less successful than planned. Starting out with high ambitions for its own term, Poland remained unsuccessful to achieve most of its own set goals (like other countries before).

Thus, one major topic addressed by non-Polish voices was whether or not the presidency position in general has any impact. It was frequently mentioned in the quotes, that countries (not just Poland) may have good intentions, ambitions and an overall good approach, but that those goals and objectives are rarely fulfilled, especially not when the respective country does not have a high power status among EU member states. Also, other high-ranking issues (especially the Eurocrisis) over- 
shadowed the Polish presidency term significantly and were in both countries' news coverage also seen as the major "stumbling block" for the country's successful performance. Here, Poland was positively evaluated for not striving for overambitious goals but remaining pragmatic.

Altogether, the Polish and non-Polish voices in both German and Austrian news perspectives did not contradict each other, but the Polish voices we traced in the news coverage implicitly support the evaluation that was given of the Polish presidency performance by non-Polish voices. It was more the power and potential influence of the position itself that was blamed for the failure of the Polish ambitions and goals for its presidency term.

\section{How is Poland evaluated beyond its EU Presidency performance?}

Beyond the country's performance as holder of the EU Presidency, articles in both German and Austrian print media also voiced additional evaluations of Poland, hereby addressing different issues or thematic areas: With regard to the Polish economic situation, it was pointed out in several articles that Poland has a strong, dynamic and growing economy, and should be taken as a role model for other EU countries, especially in view of the current Eurocrisis (e.g., for the way it dealt with its own threat of state bankruptcy in 1989). Voices stated that the country almost meets the Maastrich criteria for Euro and has benefitted from EU subventions. However, in the German context it was also pointed out in two articles, that this stability was also achieved because if the help of the EU (here referring to the Stability and Growth Pact again).

With regard to the Polish political situation, both German and Austrian press included voiced positively emphasizing that the country had overcome its internal turmoil caused by pro- and anti-EU political forces (Lech Kaczyński era) and now had a solid pro-EU government under Tusk, which was also seen as a political improvement towards a now more realistic, diplomatic and efficient foreign and EU policy. Several voices pointed out that the country was now a stable democracy (compared to its Communist past), and Poland was referred to as a spearhead in fighting communist dictatorship. Also highlighted were the positive relations Poland has now established with Germany (mainly in German but also in Austrian news coverage), and that Poland serves as an important inter-mediator between the EU and non-EU countries in Eastern Europe such as Russia, Ukraine, or Belarus.

On a critical note, in both country samples a number of statements critically commented on the Polish environment politics. Here, it was argued that the country is quarrelsome and blocks EU and international agreements for the improved use of environmental-friendly energy sources and the shutdown of nuclear power plants. Especially in the German sample this was criticized by quoted actors, because Germany holds contrary positions to the Polish policy (e.g., supporting the long-term strategy of an EU-wide shutdown of nuclear power plants in favor of other regener- 
ative energy sources). Here, actors critically remarked that the Polish national interests might not be compatible with the country's acclaimed effort as EU presidency holder to unite the EU.

Altogether, those perceptions did not fully differ from the evaluations of the Polish EU presidency performance, and they were also not contradictory. Nevertheless, we did find critical voices here, as well. This was especially the case in the German news coverage, which overall was slightly more critical than the Austrian one.

\section{The Polish EU Presidency in the German and Austrian news coverage - a summary}

Our analysis showed that the overall perspectives on Poland and its performance as holder of the EU presidency were rather similar in both German and Austrian press news coverage. First and foremost, in both countries, the publication output on the EU presidency of Poland was rather small. Both aspects were also predominantly not the central focus in news articles. Often, news items rather reported about events or actions carried out in the scope of this position. Thus, Poland was only minor visible in EU presidency-related articles in both country samples during the term. Also, neither the bi-national relations of both Germany and Austria with Poland nor both countries' relation with the EU did significantly increase or decrease the visibility of Poland in the German and Austrian news coverage, despite the fact that during that 6-month period Poland hosted a number of EU events and meetings (that were reported on but not by also taking into a closer view the host of those events).

The 6-month period of the presidency did also not lead to a significant increase in the complexity and composition of the Austrian and German news coverage of Poland in EU presidency-related contexts; even though our analysis did show that the perception of the country was not one-dimensional. Both countries' print media not only quoted a variety of Polish actors and their views on EU politics and issues, but also included additional information on Polish issues (e.g., Polish politics, economy, or foreign relations) and Polish views beyond EU presidency-related topics. This observation supports the preliminary theoretical assumptions that bi-national historical, economic, political, or cultural relations, as well as cultural or geographic proximity are also crucial factors that influence newsworthiness. That both German and Austrian print media show interest in additional features about Poland in the context of EU presidency-related content may be due to the fact, that both countries have close economic ties with Poland, a close geographical proximity to the country, or a close social proximity (i.e., cultural transfer, number of Polish immigrants).

What did change throughout the presidency term, however, was the evaluation of Poland. Here, based on our theoretical assumptions we would argue that this is also caused the German and Austrian relations with the EU and the fact that all 
three countries - Germany, Austria and Poland - are members of the same "EU family." Especially the Eurocrisis here marks a special threat to this collective entity, because of the financial problems, the political disputes and the economic dependencies that were caused with it. Those issues threatened and still threaten the cohesion of the "EU family," and in the analyzed news coverage, this major issue (for all three countries) overshadowed the perspective on Poland in the context of its EU presidency.

Nevertheless, our study showed that the evaluations of Poland in EU presidency-related content were rather neutral or even positive. Only few articles included explicitly negative or ambivalent evaluations. Thus, altogether the overall perception of Poland was not one-sided, and thus its overall performance was not perceived as a complete failure. However, despite those more complex or even positive views, the presidency did not lead to an increased relevance of and interest for Poland and Polish issues in the German or Austrian media perception. All in all, the Polish performance was portrayed as not achieving many of the self-set goals, but the fault for this failure was not primarily seen to lie with the country itself, but with external issues such as the Eurocrisis.

In addition to that, the own relationship with and political standing in the EU had a significant influence on the news context in which the perception of Poland was embedded in both German and Austrian press: In Germany, the overall news coverage was centered around the own obligations and performances on the European stage. Articles reported much stronger about the own alignments, negotiations and positions, that of other crucial EU players such as France and Great Britain, or of countries strongly affected by the Eurocrisis. This clearly interfered with and also overshadowed the Polish presidency news coverage and the perception of the same in German print media. In Austria, the Eurocrisis has further increased the Austrian skepticism with regard to EU matters, and this skepticism also reflected in the news coverage throughout the timeframe of the Polish EU presidency term. This focus pushed Poland as the presidency holder out of the limelight, while Austrian media (and political debates) focused on EU-related topics in relation to Austria and to countries that led the negotiations over bailout plans etc. (e.g., Germany, or France).

\section{References}

Asmuss, B., Ulrich, B., Koch, M. (eds) (2009), 1.9.39: Deutsche und Polen: Abgründe und Hoffnungen, Dresden: Sandstein.

Brantner, C. (2009), Medien und EU: Europäisierung der österreichischen Öffentlichkeit? Eine Inhaltsanalyse des öffentlichen medialen Diskurses zur Osterweiterung der EU und zum EU-Beitritt der Tschechischen Republik, Saarbrücken: Südwestdeutscher Verlag für Hochschulschriften.

de Vreese C. H., Semetko, H. A. (2004), “News Matters: Influences on the Vote in a Referendum Campaign", European Journal of Political Research 5, 699-722. 
Ekengren, M. (2004), “National Foreign Policy Coordination: The Swedish EU Presidency”, in: W. Carlsnaes, H. Sjursen, B. White (eds), Contemporary European Foreign Policy, London: Sage, 211-226.

Galtung, J., Ruge, M. H. (1965), “The Structure of Foreign News: The Presentation of the Congo, Cuba and Cyprus Crisis in Four Norwegian Newspapers", Journal of Peace Research 2, 64-91.

Gatzke, N. (2010), Polenbild in Deutschland: Wandel und Kontinuität - von Polen als Gegenbild der Aufklärung bis zur EU-Reformdebatte (Magisterarbeit), Potsdam: University of Potsdam, retrieved from http://www.ssoar.info/ssoar/handle/document/29050.

Gilboa, E. (2004), "Diplomacy in the Media Age: Three Models of Uses and Effects", in: C. Jonsson and R. Langhorne (eds), Diplomacy, III, London: Sage, 96-119.

Hans-Bredow-Institut für Medienforschung (ed.) (2009), Internationales Handbuch Medien (28 th ed.), Baden-Baden: Nomos.

Hargrove, T., Stempel, G. H. (2002), “Exploring Reader Interest in International News", Newspaper Research Journal 23(4), 46-51.

Kunczik, M. (2003), "States, International Organizations, and the News Media", in: P. J. Maarek and G. Wolfsfeld (eds), Political Communication in a New Era, New York: Routledge, 117-138.

Leitsch, W., Trawkowski, S. (eds.) (1993), Polen im alten Österreich. Kultur und Politik. Wiener Archiv für Geschichte des Slawentums und Osteuropas (Veröffentlichungen des Instituts für Ost- und Südosteuropaforschung der Universität Wien, $16^{\text {th }}$ ed.). Wien: Böhlau.

Leitsch, W., Trawkowski, S. (eds) (1997), Wiener Archiv für Geschichte des Slawentums und Osteuropas: Vol. 17. Polen und Österreich im 16. Jahrhundert (Wiener Archiv für Geschichte des Slawentums und Osteuropas), Wien-Köln-Weimar: Böhlau.

Maier, M., Strömbäck, J., Kaid, L. L. (2012), European Political Communication: Campaign Strategies, Media Coverage, and Campaign Effects in European Parliamentary Elections, Farnham/UK-Burlington/USA: Ashgate.

Manheim, J. B. (1994), Strategic Public Diplomacy and American Foreign Policy: The Evolution of Influence, New York: Oxford University Press.

Mayring, P. (2003), Qualitative Inhaltsanalyse: Grundlagen und Techniken (8 $8^{\text {th }}$ ed.), Weinheim-Basel: Beltz.

Nawratil, U., Schönhagen, P. (2008), “Die qualitative Inhaltsanalyse: Rekonstruktionen der Kommunikationswirklichkeit", in: H. Wagner (ed.), Qualitative Methoden in der Kommunikationswissenschaft. Ein Lehr- und Studienbuch, München: Fischer (Studienbuch), 333-346.

Ociepka, B., Łada, A., Ćwiek-Karpowicz, J. (2008), Die Europapolitik Warschaus und Berlins in der deutschen und polnischen Presse. Ein Forschungsbericht, Warschau: Instytut Spraw Publicznych, retrieved from http:/ / www.isp.org.pl/files/4184425580093185001213726958.pdf.

Ostgaard, E. (1965), "Factors Influencing the Flow of News", Journal of Peace Research 2, 39-63.

Potkanski, M. (2011), Polnische Migrant/innen in Österreich: Zahlen. Fakten. Einstellungen (ÖIF-Dossier 20/Österreichischer Integrationsfonds), Wien, retrieved from http://www.integrationsfonds.at/oeif_dossiers/polnische_migranten_in_oesterreich/.

Quagllia L., Moxon-Browne, E. (2006), “What Makes a Good EU Presidency? Italy and Ireland Compared", Journal of Common Market Studies 2, 349-368. 
Risse-Kappen, T. (2010). A Community of Europeans? Transnational Identities and Public Spheres, Ithaca, NY: Cornell University Press.

Rivenburgh, N. K. (2010), "In Pursuit of a Global Image: Media Events as Political Communication", in: N. Couldry, A. Hepp, F. Krotz (eds), Media Events in a Global Age, London-New York: Routledge, 187-202.

Semetko, H. A., Brzinski, J. B., Weaver, D., Willnat, L. (1992), “TV News and U.S. Public Opinion About International Countries: The Impact of Exposure and Attention", International Journal of Public Opinion Research 1, 18-36.

Shoemaker, P. J., \& Cohen, A. A. (eds) (2006), News Around the World: Content, Practitioners, and the Public, New York: Routledge.

Signitzer, B. H., \& Coombs, T. (1992), “Public Relations and Public Diplomacy Conceptual Convergences", Public Relations Review 2, 137-147.

Staab, J. F. (1990), “The Role of News Factors in News Selection: A Theoretical Reconsideration", European Journal of Communication 5(4), 423-443.

Stępińska, A. (2013), "International Project: Media Coverage of the Polish EU Presidency", Środkowoeuropejskie Studia Polityczne (Central European Political Studies) 3, 71-85.

Szarota, T. (2010), Stereotype und Konflikte: Historische Studien zu den deutsch-polnischen Beziehungen (Historische Dialoge: Vol. 1), Osnabrück: fibre.

Trenz, H. J. (2004), “Media Coverage on European Governance. Exploring the European Public Sphere in National Quality Newspapers", European Journal of Communication 3, 291-319.

Vitouch, P., Mayer, M. (2004), “Quantitative Inhaltsanalyse: Erhebung und Analyse von Beiträgen der 'Kronenzeitung', die EU-Skepsis vermitteln", in: H. Krejci (ed.), Grundlagen des Skeptizismus gegenüber der Europäischen Union und dem Euro, Wien: ARGE Informations- und Medienforschung, 8-18.

Wanta, W., Mikusova, S. (2010), “The Agenda-setting Process in International News”, Central European Journal of Communication 2 (5), 221-235.

Weber, P. (2010), “No News from the East? Predicting Patterns of Coverage of Eastern Europe in Selected German Newspapers", International Communication Gazette 72(6), 465-485.

Wilke, J., Reinemann, C. (2007), “Invisible Second-order Campaigns? A Longitudinal Study of the Coverage of the European Parliamentary Elections 1979-2004 in Four German Quality Newspapers", Communications 32, 299-322.

Wilke, J., Heimprecht, C., Cohen, A. A. (2012), “The Geography of Foreign News on Television: A Comparative Study of 17 Countries", International Communication Gazette 74(4), 301-322.

Wöhlert, Romy (2013a), “The Austrian News Coverage of Poland During the Polish EU Presidency in 2011", Środkowoeuropejskie Studia Polityczne (Central European Political Studies) 3, 87-107.

Wöhlert, Romy (2013b), “The German News Coverage of Poland During the Polish EU Presidency Term in 2011", Środkowoeuropejskie Studia Polityczne (Central European Political Studies) 3, 121-143.

Wu, H. D. (2000), “Systemic Determinants of International News Coverage: A Comparison of 38 Countries", Journal of Communication 50(2), 110-130. 
Stijn Joye, Khaël Velders, Daniël Biltereyst, Thibault Bonte, Eveline Delcart

Ghent University, Belgium

\section{Poland Between PR and Presidency: A Quantitative and Qualitative Content Analysis of Belgian Newspaper Reporting on the Polish Presidency of the EU Council}

\section{Introduction}

Although international institutions and transnational governments have unmistakably played a prominent role in the global and local politics of recent years, European Union politics and governance have been and are still perceived by its citizens as remote and abstract (Blumler, 1983; Cini \& Borragán, 2013). News coverage of EU-related events and topics in the media, suggested by recent studies as providing the most important link between politics and citizens (Entman \& Bennett, 2001), could play a key role in the representation of the European Union and the further integration of its central government and its member states.

Acknowledging the importance of these dynamics, cross-national and longitudinal comparative research on the media coverage of EU-related news has gained an increasing interest and momentum, but are still rare. The findings of these analyses indicate that news coverage of EU affairs is cyclical, peaking around key events (de Vreese et al., 2001; Norris, 2000). Trenz (2004), for one, argues that a European mediated public sphere has emerged. While Leroy and Siune (1994) suggest a tendency to domesticate EU-related news and hence make it more relevant and appealing to local audiences, Peter, Semetko \& de Vreese (2003) conclude that this is not the case. They argue that these different findings may be the result of the fact that the study by Leroy and Siune (1994) analyzed news during a key event, while they focused on news coverage during a routine period. As the visibility of EU news has increased overall (Boomgaarden et al., 2012), there is little consensus on the status of European integration. Peter and de Vreese (2004:3) thus conclude that "[...] the Europeanization of television news coverage is more an illusion than reality."

Regardless of its outcome, the body of scholarly work on the news coverage of EU affairs is generally focused on the EU as an intergovernmental institution. While it does provide a clear view on the coverage of EU-related events in its respective member states, it largely remains ignorant of the particular flows of news in between the member states of the EU. The latter is the main concern of the quantitative content analysis that we will present in this book chapter. In order to contextualize and deepen the findings from the quantitative study, the chapter further draws on 
a brief qualitative analysis. Here, the focus lies on the represented image of Poland and the Presidency of the EU council in Belgian print media.

\section{Media coverage of the Polish EU Presidency in Flanders}

The following study provides insight into the media coverage of the Polish EU Presidency in the region of Flanders, the Dutch-speaking Northern part of the EU founding member Belgium.

For the quantitative content analysis, our scope is narrowed to three Flemish media sources: the broadsheet De Standaard, the popular newspaper Het Laatste Nieuws and the weekly magazine Knack. The denotation of "popular newspaper" is not to be equated with the concept of a "tabloid": while Het Laatste Nieuws does provide more coverage of topics related to sports and human interest, it still operates within the margins of "midmarket" dailies by providing news reporting of political and socio-economic subjects and by appealing to a broad spectrum of the different social categories within the newspaper audience (De Bens \& Raeymaeckers, 2007). We collected the data by using the Mediargus database, an online search tool for archived newspaper articles, enabling us to search for references relevant in the context of this study. We used the keywords Polen, Pool, Pools and Poolse. These are the Dutch translations of the search terms Poland, Pole, Polish (male conjugation), and Polish (female conjugation). We restricted the scope of our search to three six week periods: these three six week periods covered data respectively from June 15, 2011 to July 31, 2011; from September 1, 2011 to October 15, 2011; and from December 1, 2011 to January 15, 2012. We gathered 735 news articles in total after inspection and deletion of duplicates. After the collection of the data, we followed up with a quantitative statistical analysis of the news articles by applying standard SPSS statistical tools. We have coded the news items based on an aggregated codebook, containing sixteen variables, which had been distributed to the research teams that participated in the comparative study.

To complement the quantitative study, we have conducted a qualitative analysis of a larger sample of news articles. We have opted for an inductive or 'conventional' qualitative content analysis (Hsieh \& Shannon, 2005) with articles as our basic units of analysis. After the initial coding stage, the data were compared and further analyzed in several cycles. Taken the specific Flemish context into account, three distinct thematic categories emerged from the data: politics, culture and stereotypes. With regard to the corpus for the qualitative research, we have expanded the initial sample in terms of observed media and time period. Next to De Standaard, Het Laatste Nieuws and Knack, we selected articles on the Polish Presidency that were published in two other Flemish newspapers (the up-market De Morgen, and the popular newspaper Het Nieuwsblad) while expanding the time frame to a six-month period of 15 June 2011 till 17 January 2012. In total 28 articles explicitly dealt with the EU Presidency of Poland. In accordance with the findings from the quantitative re- 
search, the quality newspapers published most articles, that is ten each. Our sample consisted of traditional news articles as well as of some columns and more personal accounts by journalists who for instance went on a 'road trip' through Poland as part of a feature on the EU Presidency.

\section{Results of the quantitative content analysis}

\section{News media and size of the news item}

Let us first turn to a brief discussion of the origin and size of the coded news articles $(n=735)$. Out of the 735 articles, 479 articles or $65 \%$ of the data set originated from the popular newspaper Het Laatste Nieuws, while 205 articles or $27.9 \%$ of the items were published in the broadsheet De Standaard. Only 51 news items or $6.9 \%$ were gathered from Knack. These numbers are easily explained by pointing out that, in contrast to De Standaard and Het Laatste Nieuws, Knack is a magazine published on a weekly basis which severely limits its ability to report news at the same frequency as the selected newspapers. Furthermore, we would like to address attention to the anecdotal observation that only one of all 735 coded articles appeared on the front page of one of the selected sources (i.e. De Standaard).

Table 1

Descriptives for size of news articles

\begin{tabular}{|c|c|c|c|c|c|c|c|c|}
\hline & \multirow{2}{*}{$\mathbf{N}$} & \multirow{2}{*}{ Mean } & \multirow{2}{*}{$\begin{array}{l}\text { Std. De- } \\
\text { viation }\end{array}$} & \multirow{2}{*}{$\begin{array}{l}\text { Std. } \\
\text { Error }\end{array}$} & \multicolumn{2}{|c|}{$\begin{array}{l}\text { 95\% Confidence } \\
\text { Interval for Mean }\end{array}$} & \multirow{2}{*}{ Min. } & \multirow{2}{*}{ Max. } \\
\hline & & & & & $\begin{array}{l}\text { Lower } \\
\text { Bound }\end{array}$ & $\begin{array}{l}\text { Upper } \\
\text { Bound }\end{array}$ & & \\
\hline De Standaard & 205 & 618.5317 & 566.67349 & 39.57819 & 540.4969 & 696.5665 & 52.00 & 3006.00 \\
\hline $\begin{array}{l}\text { Het Laatste } \\
\text { Nieuws }\end{array}$ & 479 & 304.7349 & 250.76391 & 11.45770 & 282.2212 & 327.2485 & .00 & 2883.00 \\
\hline Knack & 51 & 1049,4314 & 909.97176 & 127.42153 & 793.4977 & 1305.3651 & 35.00 & 3265.00 \\
\hline Total & 735 & 443.9293 & 482.94778 & 17.81380 & 408.9572 & 478.9013 & .00 & 3265.00 \\
\hline
\end{tabular}

Table 2

One-way ANOVA for size of news articles

\begin{tabular}{|l|c|c|c|c|c||}
\hline & Sum of Squares & df & Mean Square & F & Sig. \\
\hline Between Groups & 34228569.440 & 2 & 17114284.720 & 91.464 & .000 \\
\hline Within Groups & 136968528.881 & 732 & 187115.477 & & \\
\hline Total & 171197098.321 & 734 & & & \\
\hline
\end{tabular}


Table 3

Posthoc Scheffe test for size of news articles

\begin{tabular}{|c|c|c|c|c|c|c|}
\hline \multirow[b]{2}{*}{ (I) media } & \multirow[b]{2}{*}{ (J) media } & \multirow{2}{*}{$\begin{array}{l}\text { Mean Dif- } \\
\text { ference (I-J) }\end{array}$} & \multirow{2}{*}{$\begin{array}{l}\text { Std. } \\
\text { Error }\end{array}$} & \multirow[b]{2}{*}{ Sig. } & \multicolumn{2}{|c|}{$95 \%$ Confidence Interval } \\
\hline & & & & & $\begin{array}{l}\text { Lower } \\
\text { Bound }\end{array}$ & $\begin{array}{l}\text { Upper } \\
\text { Bound }\end{array}$ \\
\hline \multirow{2}{*}{$\begin{array}{l}\text { De } \\
\text { Standaard }\end{array}$} & Het Laatste Nieuws & $313.79684^{*}$ & 36.10258 & .000 & 225.2457 & 402.3480 \\
\hline & Knack & $-430.89967^{*}$ & 67.68818 & .000 & -596.9228 & -264.8765 \\
\hline \multirow{2}{*}{$\begin{array}{l}\text { Het Laatste } \\
\text { Nieuws }\end{array}$} & De Standaard & $-313.79684^{*}$ & 36.10258 & .000 & -402.3480 & -225.2457 \\
\hline & Knack & $-744.69651^{*}$ & 63.71474 & .000 & -900.9737 & -588.4193 \\
\hline \multirow[t]{2}{*}{ Knack } & De Standaard & $430.89967^{\star}$ & 67.68818 & .000 & 264.8765 & 596.9228 \\
\hline & Het Laatste Nieuws & $744.69651^{*}$ & 63.71474 & .000 & 588.4193 & 900.9737 \\
\hline
\end{tabular}

* The mean difference is significant at the 0.05 level.

Using the size of the news articles as an indicator for the extensiveness of the news reporting, we are able to discern whether or not Knack is able to compensate for its limited frequency of coverage by providing a more in-depth analysis. The means of news article size for Het Laatste Nieuws $(\mathrm{m}=305)$, De Standaard $(\mathrm{m}=619)$ and Knack $(\mathrm{m}=1049)$ were analyzed using ANOVA $(\mathrm{p}<.05)$ and results of the analysis showed a significant difference between groups $(F(2)=91,464$ and $p=.00)$. A posthoc Scheffe test $(\mathrm{p}<.05)$ was then performed to evaluate all possible pair-wise comparisons among means, showing significant results between all three news sources' means $(\mathrm{p}=.00)$. In summary, data suggest that Knack significantly provides a more in-depth analysis, compensating for its limited coverage. However, due to a great difference in variance, an inaccuracy of the observed results have to be taken into consideration.

\section{The EU-Presidency relevance}

Second, we analyzed the relevancy of the news coverage of the EU-Presidency of Poland. The results of our analysis showed a severely low frequency of news items related to the EU-Presidency of Poland: no less than twelve or $1.6 \%$ of all articles were coded as relevant. To contextualize, this low number corresponds to the research findings of a Flemish study performed by Joye (2010) which indicated that only $0.98 \%$ of all foreign and international news concerned Poland over the period 1986 till 2006, illustrating the dominant Eurocentric focus of Flemish newspapers. Of these twelve relevant articles, only one item was published by Het Laatste Nieuws, while Knack and De Standaard respectively covered four and seven news items. Moreover, of these twelve articles six were coded as published within the first seventeen days of the first six week period (i.e. between June 15, 2011 and July 1, 2011). The timeframe coincides with the anticipation prior to the Polish EU-Presidency ef- 
fectuating on July 1,2011 . This observation could be interpreted as an illustration of the tendency of Western news media to focus on big news stories when covering foreign news (Hafez, 2007) and it illustrates the cyclical nature of news coverage on EU-related events (de Vreese et al., 2001; Norris, 2000). However, due to the very low frequency of relevant news items, it should be taken into consideration that this measurement may as well be incidental. Furthermore, in those items coded as relevant to the EU-presidency, Poland's main role was mentioned mostly as an EU member. The distribution for the size of the articles within the selected relevant news items was analyzed and showed that five out of twelve of these articles did not surpass the limit of 500 words per article.

\section{Genre}

After our investigation of relevancy, we broaden our scope back to the entire corpus of 735 articles. Concerning genre, the data set showed that 492 or $66.9 \%$ of all items were coded as news articles, while $20.8 \%$ and $5.4 \%$ were coded respectively as reportages and interviews. These shares are similar for Het Laatste Nieuws and De Standaard, while a smaller amount of news articles in favor of a greater focus on interviews can be observed for Knack.

Table 4

Descriptives for genre of news articles

\begin{tabular}{|l|c|c|}
\hline \multicolumn{1}{|c|}{ Genres } & Frequency & Percent \\
\hline News & 492 & 66.9 \\
\hline Reportage & 153 & 20.8 \\
\hline Editorial & 6 & 0.8 \\
\hline Column & 10 & 1.4 \\
\hline Commentary & 6 & 0.8 \\
\hline Guest contribution & 13 & 1.8 \\
\hline Interview & 40 & 5.4 \\
\hline Letter to editor & 7 & 1.0 \\
\hline Other & 8 & 1.1 \\
\hline Total & 735 & 100.0 \\
\hline \hline
\end{tabular}

\section{Visual elements and relevance of visual elements to Poland}

Furthermore, all news articles were analyzed for the presence of visual elements in the coverage. Out of all articles, 378 or $51.4 \%$ contained a picture, while 321 articles or $43.7 \%$ did not carry any visual elements at all. Only 62 or $8.4 \%$ of all news items contained visual elements that are relevant to our object of inquiry, the Polish EU-Presidency. 


\section{Author of news and author of opinion}

The next variable for which the news articles were coded, is the author of the item. For this variable, a distinction was made between author of news and author of opinion. News articles previously coded as news and reportages for the genre variable were categorized as 'news material' and analyzed via the 'author of news' variable, whereas the items coded as all other genres - except for the genre 'other' - were categorized as 'not news material' and analyzed using the 'author of opinion' variable. The analysis of this latter category showed that the different authors of opinion were somewhat equally distributed across the news items, the exception being national experts who accounted for $35.4 \%$ of the articles categorized as 'not news material'. For those articles classified as 'news material', the results were remarkably different: $95 \%$ of all news items had staff members identified as the authors of news, which is a logical consequence of the distribution across the variable for source of information. The latter proved to be problematic as 591 or $80.4 \%$ of the coded items did not mention its original source, preferring to cite the full name or initials of the news item contributor. Moreover, in 5\% of the cases no source at all was mentioned.

\section{Dominant topic area}

All items were coded to discern exactly one dominant topic throughout the news article; the most recurring ones being sports (38.8\%), justice and crime $(15.5 \%)$, and culture $(12.4 \%)$. When comparing the distribution of dominant topics across the selected news sources, results showed that Het Laatste Nieuws accounted for $82.5 \%$ of all sports articles and for $78.1 \%$ of all justice and crime articles. These results correspond with Het Laatste Nieuws' profile as a popular newspaper in particular and the increasing tendency of tabloidization in general (De Bens \& Raeymaeckers, 2007). For the dominant topic of culture, most articles were gathered from De Standaard: this broadsheet newspaper accounted for 40 or $44 \%$ of the articles, while Knack and Het Laatste Nieuws accounted for $25.3 \%$ and $30.8 \%$, respectively. When narrowing our scope to the dominant topics recurring in the news articles related to the Polish EU-Presidency, we observe that six out of twelve articles have recourse to culture and four out of twelve items have to do with international politics. This is an interesting observation, as it demonstrates that even when news articles are considered relevant to the EU-Presidency of Poland, they are not necessarily political in nature but rather cultural (cf. infra).

\section{Domestication and dateline}

We coded and analyzed the data for dateline and domestication, two variables closely related to one another. The most frequently recurring dateline was Belgium, 
which was mentioned in 453 news articles or $61.6 \%$ of the sample. A noticeable gap was observed between this and the next dateline; namely Poland, which accounted for $14 \%$ of the news items. Focusing on the domestication variable, we are able to discern that 628 or $85.4 \%$ of all news articles made an explicit reference to national or domestic issues and persons. This finding is consistent with previous studies on foreign and international news reporting in Flemish media (cf. Joye, 2010) which have all identified the broad concept of proximity as a key news value that determines the selection process and the amount of attention that is devoted to the event.

Table 5

Descriptives for domestication of news articles

\begin{tabular}{||l|c|c||}
\hline \multicolumn{1}{|c|}{ Strategies } & Frequency & Percent \\
\hline Explicit reference to nationals & 628 & 85.4 \\
\hline Explicit reference to impact & 5 & 0.7 \\
\hline Reference to nationals and visual elements & 3 & 0.4 \\
\hline No & 99 & 13.5 \\
\hline Total & 735 & 100.0 \\
\hline
\end{tabular}

Main role of and attitude towards Poland

Finally, a short word on the role of and the attitude towards Poland in the analyzed news items. Only in eight out of 735 items or $1.1 \%$ was Poland mentioned as an EU member. Furthermore, Poland was only cited as the host of an EU-related meeting in two news articles. Nearly every news item, accounting for $98.4 \%$, was coded as 'other' regarding attitude toward Poland. This does not imply a neutral attitude, but rather a complete absence of any subjectivity in news reporting on Poland or its EU Presidency.

In the next section of the paper, we will present findings of the qualitative content analysis and focus on the three distinct thematic categories that emerged from the data: politics, culture and stereotypes.

\section{Findings of the qualitative content analysis}

\section{Politics and the Polish Presidency}

Although one would logically expect that political themes and issues are the dominant perspective in the news coverage of the EU Presidency, this was clearly not the case. Only thirteen articles had a clear and sole political interest, just as many as the culturally oriented articles. In addition and in terms of the country's reputation, the 
politically oriented articles did not sketch a very positive image of Poland. There were a number of reasons for this. First of all, Poland did not start off that well in July 2011 with the country being the only one to prevent the unanimous endorsement by the 27 European Union countries of a strategy document that would strengthen the EU's climate change policy. Later on, several articles in the Flemish news media referred to this action and some journalists defined it as "a misstep" or "a lack of solidarity". Secondly, the same situation of an isolated Poland against the rest of the EU occurred again in September 2011 when Poland invited the USA Minister of Finance, Timothy Geithner, to attend an informal meeting on the Eurozone. Other European ministers were quoted as being "not amused" with this surprise visit, resulting in some sharp-tongued reactions. One Flemish journalist euphemistically described the incident as follows: "Host country Poland has not left the best impression with this solo act." Moreover, the good relationship between Warsaw and Washington was explicitly mentioned on other occasions as well, with some insinuations on the influence of the USA over Poland and, henceforth, implicitly portraying Poland as a USA 'puppet' rather than as an independent and strong political actor. A third element popped up in December 2011 as part of the enduring Euro-crisis. Flemish journalists perceived an apparent emergence of an anti-European sentiment among the countries of the 'New Europe' (the former Soviet-countries), including Poland who has decided to postpone the introduction of the Euro to 2015. One article titled: "New Europe falls out of love with the Euro!" Except for the latter issue, what is however noteworthy with these incidents is that their relevance is always downplayed or minimized by repeatedly stating that "It is Poland's first time as president of the Union," thus stressing the country's inexperience as a valid explanation and simultaneously eliciting a sense of empathy or forgiveness. So while the actual events and their coverage casted a rather negative light over the chairing country, there was also a significant discursive counter practice in Flemish news media that reduced the impact of the political incidents on the country's image and reputation.

Another remarkable observation concerns the absence of Poland - as the EU's chairing country - in Europe's key political discussions at the time, most notably the debate on the financial crisis. The above mentioned incidents are substantially highlighted by the Flemish press, but when moving beyond that, Poland was only mentioned once in the coverage of political meetings. In line with this, there was almost no attention for the other goals and objectives that Poland announced at the beginning of its Presidency, except for the discussions on the budget of the EU. The topics of defense and an opening up towards the East were (briefly) mentioned in news reports at the start of the Presidency in July, however, they failed to attract much follow-up news. In terms of attention devoted to the political activities and initiatives of Poland, the data identify a clear bias towards the more sensational and negative.

In conclusion for the political dimension of the Presidency, the overall evaluation of Poland's Presidency was not very positive. At the start of the Presidency, one Flemish journalist openly wondered whether Poland would be able to have an im- 
pact on the political level. He seriously doubted it, but immediately added that Poland's opportunities to make an impact and potentially adjust its image were not to be found at the political level, but rather at the cultural. Given the above discussed political 'track record' of Poland as the EU's chairing country and our findings with regard to the cultural dimension (cf. infra), our data certainly confirm this.

\section{If not political, then a cultural Presidency?}

The qualitative content analysis exposed a dominant cultural frame in the Flemish news reporting on the Polish Presidency. One journalist called it "Poland's true flagship," underlining the cultural legacy and richness as the country's natural asset or strength while others identified the focus on culture as part of a clever - yet expensive - marketing plan with the purpose of branding Poland as "a modern nation with a rich culture and as the creative hub between East and West." Spearheading this campaign of more than 400 events in merely six months was the 'I, Culture' program that featured several expositions in different world cities, including Brussels, Paris, London and New York. The Flemish newspapers and weekly mainly focused on the exposition in Brussels but different articles gave a very elaborated outline of the diversity of Polish culture: music (e.g. with composers such as Frederic Chopin - although all articles began with stating that there is more than just Chopin -, Karol Szymanowski and Krzysztof Penderecki); literature (e.g. Czesław Miłosz and Adam Zagajewski); theatre (e.g. Stanisław Lem and Krzysztof Warlikowski); cinema (e.g. Roman Polański); and fine arts (e.g. Henryk Stażewski). The general evaluation of the cultural component of Poland's Presidency was very positive as Flemish journalists used characteristics such as "high quality", "rich", "world class", "willful and rebellious", "top of the bill composer", "international allure", "innovators", ... thus stressing the country's high-quality cultural capital.

It was interesting to notice that quite a few newspaper articles linked the cultural efforts and qualities of Poland to its particular (political) history and the prevailing stereotypes about the country (cf. infra). Art and culture were portrayed as a response and a form of resistance to these deeply embedded clichés as well as to political, religious and conservative forces from the past and the present. The 'I, Culture' project for instance was aimed at improving the relationship between the EU and the former Soviet countries. Other cultural projects were part of a broader campaign to improve Poland's overall image (cf. infra). A related side-effect of these cultural efforts was the profiling of Poland as a tourist destination. Several articles promoted cities such as Warsaw and Cracow as trendy, nearby and budget-friendly locations for shopping, sightseeing and - of course - culture.

In short, the Presidency was basically seen as the lever to accomplish the above, a unique opportunity to showcase cultural Poland to the rest of Europe and the world. One final example of this successful strategy was the fact that only one website was mentioned in all the Flemish news coverage of the EU Presidency, that 
is www.poolsecultuur.eu (translation: www.polishculture.eu). As one journalist stated: "Poland decisively seized the opportunity of the EU Presidency with both hands to make its culture more known across the globe." On a long term and with the selection of Wrocław as one of the European capitals of culture in 2016, not a bad strategic choice to make.

\section{Stereotypes: the persistent perception of Poland in Belgium/Flanders}

A final category of news articles dealt with some comments and opinions by Flemish journalists who have traveled through Poland and presented an "insider's look". These articles mainly tackled the prevailing stereotypes and clichés that Belgians hold true about Poland and Polish people. From the three categories that we have discerned, this is the one that explains most about the nature and roots of the dominant image of Poland in Belgium. This is achieved through some inward oriented news articles, thriving on (personal) experiences of the journalists and on standard media representations of Poland as well as on historical accounts and objective facts.

Let us first turn to the issue of stereotypes. Drawing on different articles, the following stereotypes about Polish people clearly featured the most in the Flemish news media: cheap labor force (cleaning ladies, construction workers, ...), conservative, very religious and vodka minded people. One article, however, referred to some far more negative elements of the overall Polish image; internet brides, car scams, mafia, prostitution and widespread corruption. These were all explicitly mentioned in a minority of articles. Implicitly, almost all other articles also referred to some standard 'mental' images in relation to Poland. These discursive frames were present in a more latent way, but they directed the reader to three additional elements of Poland's image or identity abroad - as perceived and reconstructed by the journalists of course. The first one deals with the holocaust, the second World War and the ambiguous position of Polish people towards Jews during these events. This is mainly represented through the image of Auschwitz. Second, the "gray" communist period, the Solidarność movement and the subsequent transition to democracy and free market, leading to a new norm of commercialism and 'bourgeoisie' was a very dominant narrative. Third, some journalists refer to leading historical personalities within Polish society: Frederic Chopin and Karol Wojtyła are frequently mentioned. The latter of course links up with the stereotype of Poland as a very religious country. Also in the context of culture, a lot of Flemish journalists overtly referred to these three (historical) elements of Polish identity as the artistic fuel and inspiration for many works of art. In general, Poland is often articulated as a nostalgic country ("tęsknota") that is characterized by a deep duality as manifested by its glorious yet also troubled history. Or in the words of one journalist: "Poland has once been called God's playground as well as the devil's dance floor." 
Two news reports clearly indicate that the Polish government is very aware of these stereotypes and perceptions of its identity abroad as the articles report on the appointment of a Flemish 'spin doctor', Thomas Vanhauwaert, by the Polish embassy in Belgium. His main task is "to clean up the image of Poland." Vanhauwaert was quoted saying that "the EU Presidency is a unique opportunity to attract attention to the country" and he suggested that the best way to improve the image is to promote the rich Polish culture. Echoing our second thematic category, Poland's culture is obviously set forth as the best way to take care of the negative perceptions.

A final note concerns the newspapers. Given the more sensational and human interest nature of the stereotypes, it was no surprise that almost all articles by popular newspapers focused on these aspects of the Polish image during the Presidency. The quality press also devoted some attention to these stereotypes, but their approach was very different. They did not just focus on the prevailing stereotypes, but they qualified and contextualized them by drawing attention to the roots of these clichés.

\section{Conclusions}

The aforementioned results of the quantitative and qualitative content analysis enable us to get a clearer picture of the news flow on the Polish EU Presidency from Poland to Belgium as well as of Poland's image or reputation as perceived and constructed by Flemish news media journalists.

Most importantly, we have observed that the analyzed news sample has devoted little attention to the Polish EU Presidency. Moreover, the coverage on this topic is concentrated around the Polish EU Presidency coming to effect. News items relevant to the EU Presidency of Poland were limited in size and did not provide a focused analysis, favoring objective news reporting with absence of a discernible attitude towards Poland. Remarkably, articles relevant to the Presidency were not necessarily political of nature: in half of the cases the dominant topic of the news items was culture. The qualitative content analysis also pointed towards a significant and even defining discursive role of Poland's rich culture in Flemish news coverage of the Presidency. Taking into consideration the entire sample set of articles, the topics of sports, culture, and justice and crime dominate the news output. This may be explained by the origin of the sampled news articles: two thirds of all articles originate from the popular newspaper Het Laatste Nieuws, which has been shown to favor coverage of these news genres. Our analysis further serves as a contemporary illustration of the often cited dynamics of domestication of foreign news (Gurevitch et al., 1991).

Drawing on the findings from both the quantitative and qualitative content analysis, the chapter essentially argues that Poland did not succeed in positioning itself as a major political actor within the European context. Flemish news media did not portray Poland in a position to define the major directions of the EU policies, despite taken up the Presidency of the council. This may be related to the then severe financial 
crisis and the situation of Greece which required other organizations and countries to step up and take the lead. The Flemish news journalists also heavily focused on the missteps on political level. By contrast, Poland was very successful in promoting and improving its cultural and touristic image. In other words, the representation of Poland's presidency was largely 'depoliticized' in Flemish news media. Instead, it was mainly represented as a key opportunity to showcase the rich cultural history and assets of contemporary Poland. In the end, the PR did take over from the presidency.

\section{References}

Bennett, W. L., Entman, R. M. (2001), Mediated Politics: Communication in the Future of Democracy, Cambridge: Cambridge University Press.

Blumler, J. G. (1983), "Key Features of Research Design”, Communicating to Voters: Television in the First European Parliamentary Elections, 25-37.

Boomgaarden, H. G., Vliegenthart, R., de Vreese, C. H., Schuck, A. R. T. (2010), “News on the Move: Exogenous Events and News Coverage of the European Union", Journal of European Public Policy 17(4), 506-526.

Cini, M., Borragán, N. P. (2013), European Union Politics, Oxford: Oxford University Press.

De Bens, E., Raeymaeckers, K. (2007), De Pers in België [The Press in Belgium], Leuven: Lannoo Campus.

de Vreese, C. H., Peter, J., Semetko, H. A. (2001), “Framing Politics at the Launch of the Euro: A Cross-national Comparative Study of Frames in the News", Political communication 18(2), 107-122.

Gurevitch, M., Levy, M., Roeh, I. (1991), “The Global Newsroom: Convergences and Diversities in the Globalization of Television News", in: P. Dahlgren, C. Sparks (eds), Communication and Citizenship. Journalism and the Public Sphere in the New Media Age, London: Routledge, 195-216.

Hafez, K. (2007), The Myth of Media Globalization, Cambridge: Polity Press.

Hsieh, H-F., Shannon, S. E. (2005), “Three Approaches to Qualitative Content Analysis”, Qualitative Health Research 15(9), 1277-1288.

Joye, S. (2010), Around the World in 8 Pages? A Longitudinal Analysis of International News Coverage in Flemish Newspapers (1986-2006), Gent: Academia Press.

Leroy, P., Siune, K. (1994), “The Role of Television in European Elections: The Cases of Belgium and Denmark", European Journal of Communication 9(1), 47-69.

Norris, P. (2000), A Virtuous Circle: Political Communication in Post-Industrial Democracies, Cambridge: Cambridge University Press.

Peter, J., de Vreese, C. H. (2004), “In Search of Europe: A Cross-National Comparative Study of the European Union in National Television News", The Harvard International Journal of Press/Politics 9(4), 3-24.

Peter, J., Semetko, H. A., de Vreese, C. H. (2003), “EU Politics on Television News A Cross-National Comparative Study", European Union Politics 4(3), 305-327.

Trenz, H. J. (2004), “Media Coverage on European Governance: Exploring the European Public Sphere in National Quality Newspapers", European Journal of Communication 19(3), 291-319. 
Katerina Serafeim

Press Office of the Regional Local Government of Central Macedonia, Greece

\section{"This is Poland calling!": Representations of the Polish EU Presidency in the Greek Media}

The purpose of the chapter is to explore and analyze the news coverage of the first EU Council's Polish Presidency in the Greek media as well as the role of the Greek media in the Greek citizens' information process about issues regarding the Polish Presidency and the promotion of European matters. It was the first time for Poland to take up the responsibilities of the EU Presidency, since the country was the largest of the new member states that entered EU during the 2004 enlargement. Although the holding of the Presidency came at a difficult time and one full of challenges for Europe, it was a unique opportunity for Poland to make the most of it and exploit the advantages that derived from its advanced position in the EU.

Through a comparative media quantitative and qualitative content analysis, the paper aims to highlight the representations of the Polish EU Presidency in Greek media, in an attempt to give circumstantial answers to the crucial questions that arise: (1) How did the Polish EU Council Presidency attract the Greek media' attention? (2) What are the Greek media's criteria of selection of EU-related events taken place in a foreign European country and are of great importance? (3) How may news items regarding the Polish EU Council Presidency appeared on Greek TV, newspapers and online media? (4) How frequently did the term "Poland", "Polish EU Council Presidency" and "Polish" appear in Greek news items? (5) What was Greek media's attitude towards the foreign country? (6) How did the Greek media present the Polish EU Council Presidency? As a host of numerous meetings and events or as an actor-in charge to define the major directions of the EU policy?

The methodological approach used is the comparative media quantitative and qualitative content analysis, which employs both a theoretical background and an empirical research. The paper is divided to two parts; the theoretical and the research part. The first provides a theoretical framework regarding the media coverage of the news about the EU and important events in member states in the light of the terms "foreign news value", "agenda setting in national media" and "domestication of foreign news". The second part is dedicated to the empirical research and the quantitative and qualitative analysis of the news items gathered.

\section{EU news coverage: theoretical perspective}

The study of media coverage of a European event, such as the EU Council Presidency, is of particular importance since media are the most important source for Eu- 
ropeans to get their information about the EU. European citizens should want to and be able to gain as much knowledge about the EU as possible in order to be aware of what happens in "the common European home" and affects their lives and future. Therefore, high visibility of EU news in the media is desirable considering media are very important source of information for the public (Mughan \& Gunther, 2000:3; Norris, 2000; Prior, 2005:579).

In order to examine the foreign media coverage of Poland and the Polish EU Council Presidency, the chapter employs the concepts of EU media coverage, media agenda, foreign news value, domestication of foreign news and sources of information about foreign events.

In relation to EU news coverage, most of the studies converge that the coverage of EU issues in the news flow is in general very low (Machill et al., 2006) except from important events such as the EU Council Presidency European elections, referenda on various EU issues or the introduction of Euro into a country (Peter, 2003:6; Peter \& de Vreese, 2004:5; Semetko et al., 2000). Some studies about EU news coverage deal only with the frequency of EU news, while others with the importance (Bruter, 2004; de Vreese \& Semetko, 2001) or prominence given by media (Peter et al., 2003, 2004; Peter \& de Vreese, 2004). When EU is covered in the news is mostly with neutral (Peter et al., 2003) or negative tone (de Vreese et al., 2006; de Vreese \& Semetko, 2003). The news about Europe also differ in their "European nature" which is the extent to which the EU is covered as a pure European issue or in terms of "domestication of news" which implies the connection to national issues and actors, with the second type prevailing (Semetko et al., 2000; Trenz, 2004).

The theoretical frame for the analysis is also related to the concept of news value, the determined role of which is undisputed in making news. News value is one of the core issues that have erased fertile debates in journalism research. Galtung and Ruge introduced in 1965 the first list of news values which was meant to be the most commonly cited list (1965; Harcup \& O'Neill, 2001). Galtung and Ruge determined twelve criteria ( 8 "culture-free" and 4 "culture-bond") which intended to give answer to the key question: why the news media in a given country might choose to cover some international events and not others. These criteria were "frequency, amplitude, unambiguousness, meaningfulness, consonance, unexpectedness, continuity, composition, elite-nation concentration, elite-people concentration, personification, and negativity".

In contradiction to Galtung and Ruge, other theorists and professionals prefer to simplify the conceptualization of the complicate subject of news value by highlighting its essential elements. Walter Lippmann, who was regarded as the founding father of the sociology of news, focusing on the process of news gathering, stressed the clarity of news. Lippmann suggested in early twenty century that the process of news gathering was "a search for the objective clear signal which signifies an event" (McQuail, 2003). News, in this sense, does not mechanically mirror reality but it reports an aspect of the event that has obtruded itself.

According to Fuller (1996), there are four agreed distinguishing elements of news: timeliness, community interest, significance, and clarity. These elements un- 
derline the influences of audience community on the making of news. "Timeliness" suggests that what is considered to be "news" is supposed to be new. The concept of newness refers not only to the time when the event happens but to the newness of the event as perceived by the community as well. Therefore, both a recent event and a recently discovered fact could become news. "Community interest" takes account of "the pull of basic human curiosity" (Fuller, 1996). "Significance" or "importance" (McKane, 2006) is usually evaluated on the basis of the "foreseeable consequences" of the event (Fuller, 1996). Both the elements of "interest" and "significance" are subjected to the perceptions, and thus bias, of the audiences. "Clarity" implies that news should be comprehensible. This is apparent given the fact that "the central purpose of journalism is to provide citizens with accurate and reliable information they need to function in a free society" (Potter, 2006).

The "domestication of foreign news" is a key factor that influences the media's "agenda setting". As Clausen (2003) points out, the term "domestication" is understood as a process of framing: recognizing, defining, selecting and organizing information as news for audiences and actors in a certain national context. Domestication refers to a process of making information fit in a frame of reference for audiences within nation state boundaries. In other words, domestication refers to processes of making information comprehensible to national audiences (Clausen, 2003). Moreover, valuation is another means of construction in news reporting. It is not rare the phenomenon that editors and journalists mix personal valuation with news reports, although objectivity is stressed in every journalism theory. Valuation can be identified over the spectrum from overt to covert valuations: Neutral, positive, negative etc. (Loffelholz \& Weaver, 2008).

The main focus of this study is the coverage of EU important events (in this case the Polish EU Council Presidency) in Greek media and the theoretical framework, which was presented above, plays a decisive role in the analysis and interpretation of the research findings that follow. Our intention was to set the basic theoretical elements, as covered by literature, upon which the empirical research is based.

\section{The news coverage of the Polish EU Council Presidency in four Greek mass media and the European Commission Newsletter}

\section{The case study profile}

In order to investigate the news coverage of the first EU Council's Polish Presidency in the Greek media, it should have been necessary to explore the Greek media landscape as a whole. Taken-for-granted that this was impossible to be included in the limits of a specific survey, we chose to present a case study regarding 4 of the most popular media in Greece and the newsletter of European Commission's Representation in Greece. The 4 media investigated were the following: (1) State (public) Television Station NET (Hellenic Broadcasting Corporation), (2) online media: 
www.ert.gr (Hellenic Broadcasting Corporation), (3) the weekly newspaper "To Vima" (English title "The Tribune"), and (4) the online newspaper (daily) www.tovima.gr.

The criteria, upon which the selection of the 4 media and the EU Newsletter was made, were the nationwide cover of the aforementioned media, their high circulation readership, the viewership, audience ratings in combination to their "origin" (state owned stations), as well as the "co-existence" of their "traditional" profile along with their online profile. Before moving on to the empirical research, it would be useful to present the basic characteristics of the mass media that were analyzed as well as their ranking in the audience's preferences in order to justify our selection.

NET is one of the 3 state television stations of the Hellenic Broadcasting Cooperation (ERT S.A.). ${ }^{1}$ NET has mainly an informative orientation and holds the responsibility of transmitting news and broadcasts the prime time evening news bulletin. According to Nielsen Audience Measurement Greece, for the period from June 2011 to January 2012, NET was ranked among the lasts places of people's choices. ${ }^{2}$

Ert.gr is the portal of ERT S.A. which has continuous news flow and live streaming. ${ }^{3}$ Moving on to the print media field, the newspaper "To Vima" is a Sunday newspaper (weekly circulation). It used to have a daily circulation as well but the financial crisis, that has affected the Greek media since 2010, led to the interruption of its daily circulation. According to the Greek Newspaper Circulation Nationwide Bulletin, during the period from June 2011 until January 2012, the newspaper "To Vima" was ranked in the second place of peoples' viewership. 4 The newspaper also has an electronic edition "www.tovima.gr". "Tovima.gr" is ranked 40 in Greece to the Alexa traffic rankings. ${ }^{5}$ Lastly, the European Commission's Newsletter is published every week and it consists of Press Releases regarding actions, measures, legislative works, activities of the Parliament, the Commission and the Council,

1 On June 11 th 2013, the Greek government announced its decision for the closure of ERT with the rationale that it was part of the attempt to cut down the public spending and meet the terms of the bailout deal. The new Greek Public Television (the interim Greek public broadcast service- EDT) emitted its signal just after 8:30am on Wednesday July $10^{\text {th }}$. 2 http://www.agbnielsen.com/whereweare/dynPage.asplang=local\&id=248\&country=Greece. 3 Compared with the overall internet population, its audience tends to be between the ages of 35 and 45; it also appeals more to highly educated, childless men browsing from home. About $27 \%$ of visits to the site are bounces (one page view only), and visitors to the site spend approximately 34 seconds on each page view and a total of three minutes on the site each day. Search engines refer approximately 16\% of visits to Ert.gr (Alexa, 2012).

${ }^{4}$ http:/ / www.marketingweek.gr/ ?pid=9\&arID=42235\&la $=1$.

5 http://www.alexa.com/search?q=tovima.gr\&r=home_home\&p=bigtop. Compared with internet averages, this site's audience tends to be between the ages of 25 and 55; they are also disproportionately childless, highly educated men. Approximately $82 \%$ of its visitors are in Greece, where it has attained a traffic rank of 32. Approximately $42 \%$ of visits to Tovima.gr are bounces (one page view only), and its visitors view 3.4 unique pages each day on average. Based on internet averages, tovima.gr is visited more frequently by males who are in the age range 35-44, have no children and are college educated (Alexa, 2012). 
statements and activities of the Commissioners. It is the official representative of the European Commission in Greece and its newsletter just presents events and statements of the EU officials.

Journalistic materials (news items, reportage, editorials, column, news commentary, press review, comments, reports, interviews and others) were collected during the period from June 15, 2011 until January 30, 2012. The data were selected by using the keywords "Poland and EU Council Presidency", "Polish EU Presidency", "Poland", "Polish" and were coded using as a methodological tool a coding guide for analyzing the research findings. The basic tools used in the survey to evaluate the representation of the Polish EU Presidency in Greek media are the following: (1) the amount of news flow regarding Poland as well as the frequency of news coverage of the country during the period of the Presidency; (2) the dominant frames and perspectives used in news materials; (3) the sources of information presented in the media (journalist, foreign correspondent, news agencies, national news organizations, other media); (4) the news items' relevance to Poland; (5) the major actors involved; (6) the opinions that are expressed in articles, comments and analyses; (7) the sources of comments and analyses; and (8) the Greek media's attitude towards Poland.

\section{Findings}

\section{NET (Greek State TV)}

During the six-month sampling period, the state television station broadcast only 8 news items referring to Poland. Among them, only 1 was dedicated directly to the EU Polish Presidency, presenting the beginning of the 6-month holding of the EU Council Presidency, as well as the aims and priorities of the country. This was the only detailed reportage to the undertaking of the rotating EU helm, with special references to the fact that Poland is a post-communist country and since its accession, the economy has seen rapid growth being the only EU country not to have experienced a recession in the last 20 years. Noteworthy is the duration of the reportage, the details, the comments of the anchorwoman and the reportage from the TV station's correspondent from Poland, giving the pulse of the news. Noteworthy as well is the station's attitude towards Poland, giving emphasis on the fact that, although the said EU member state is a former communist country, the rapid economic growth and the attempts of the country to prove to the EU that it can succeed in its new role to overcome the economic crisis in the European Union. So, the attitude towards the Polish Presidency is positive with some negative hints about the "communist past" of the country.

Five of the rest of the news items referred to Poland just as the venue country and host of the EU Summits, EcoFin and Eurogroup Summits, the formal meeting be- 
tween the Greek Prime Minister G. Papandreou and the President of the European Council H. Van Rompay, giving more emphasis to the EU summit in October 26, 2011, which was crucial for the future of the Greek financial crisis. All of the above news items were seen under the spectrum of the Greek financial crisis and the reference to Poland was only as a local definition and with neutral attitude. Even in the last news item, about the beginning of the Danish EU Council presidency, the only reference was to the rotating presidency and to the fact that the successor of the EU presidency is again a country out of the Eurozone. Finally, one reportage was dedicated to the Polish elections (October) in the middle of presidency as disorientation from the purpose of presidency.

As we can see in Figure 1, the majority of NET's news coverage about EU events $(58 \%)$ was not relevant to Poland.

Figure 1. NET's news coverage relevance to Poland

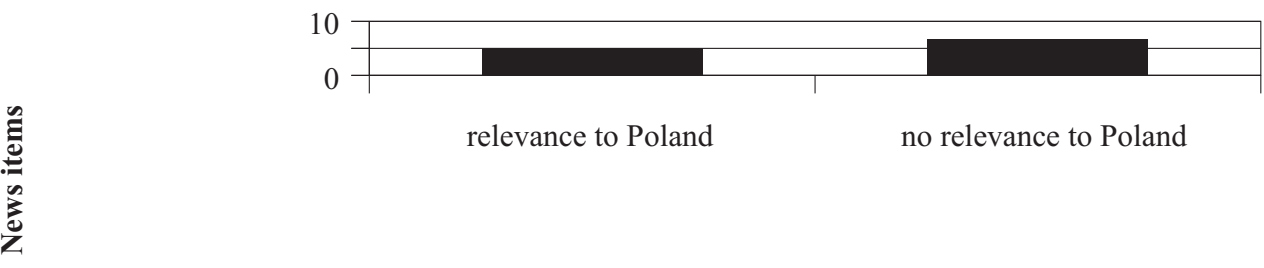

Relevance to Poland

The state television paid the minimum attention directly to the Polish EU Council Presidency and focused on other topics, not related to the Presidency but in the framework of the financial crisis that is plaguing Greece, dedicating more time to the European procedures for exiting the crisis. The financial situation in Greece monopolized NET's interest and that is the reason the dominant topic was economy (Figure 2).

Figure 2. NET's news coverage dominant topic

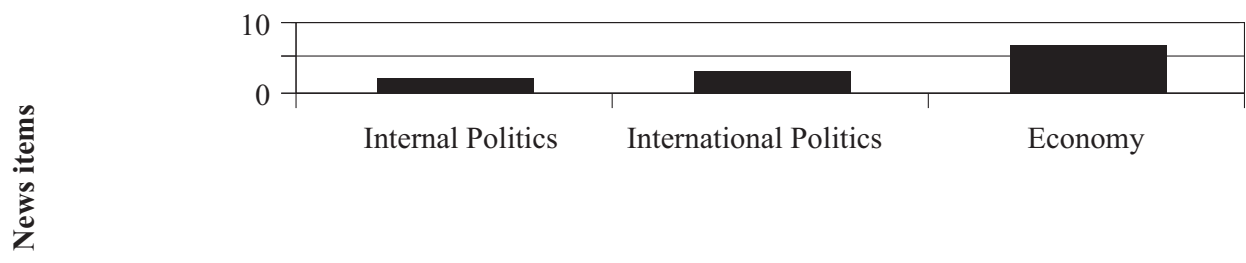

Dominant Topic

Even the news items that were related to Poland were about sports and referred to the hosting of the European Football Cap of 2012. All the news items related to 
Poland were characterized by references to nationals (Greece) and impact on the country. In general the attitude towards Poland was neutral, with a small reliance to stereotypes and skepticism on the role of Poland in the holding of the Presidency (Figure 3).

Figure 3. NET's attitude towards Poland

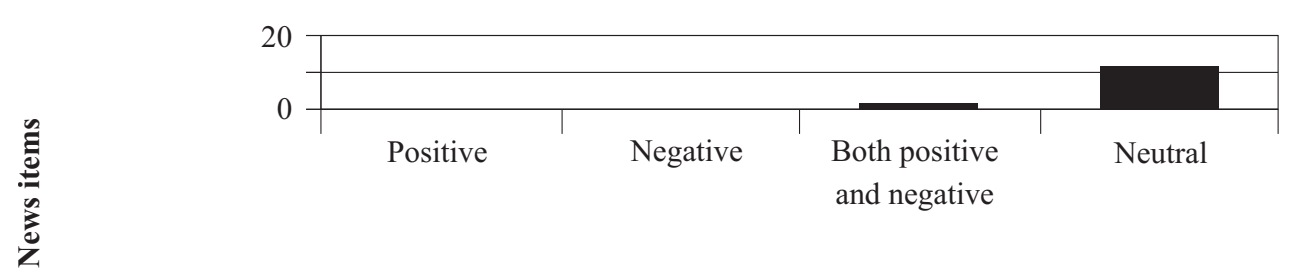

Attitude towards Poland

\section{Online media}

\section{ERT.GR}

In order to evaluate the journalistic material posted on www.ert.gr, we have to take under consideration that the above portal belongs to the Hellenic Broadcasting Corporation, as well as NET, and as a result the portal post almost the same news items as the television station broadcasts. The difference is that the portal posts news deriving from the Athens News Agency- Macedonian Press Agency (Greek national news agency), while NET broadcasts reportages done by the station's journalists. In relation to that, it is important to say that the portal, although it has staff with expertise in international news, the main source of information is the national news agency.

During the sampling period, www.ert.gr posted only 12 news items, in the same notion as NET did and with the same topics. As a portal with news streaming, ert.gr should have wider and more detailed news coverage about the Polish EU Council Presidency, with special references regarding the aims, priorities and actions of the Polish Presidency itself. News items and reportages regarding the Polish Presidency were posted on the front web page as part of the article and continued with a link in new "window".

The portal paid little attention to the Polish EU Presidency (see Figure 4), focusing more to Poland as host of events and venue (mainly for the EURO 2012 and for the EU summits as well). The majority of the news items posted were under the category of "sports", with main subject the football matches and the players taking part in the championship. Indicative of the minor importance the portal gave to the Polish EU Council Presidency is the fact that neither one of the news items about 
Poland was full displayed on the front web page. On the contrary, part of the articles was displayed in the front page accompanied by a link leading to a separate "window".

Figure 4. Greek online media's news items' relevance to Poland

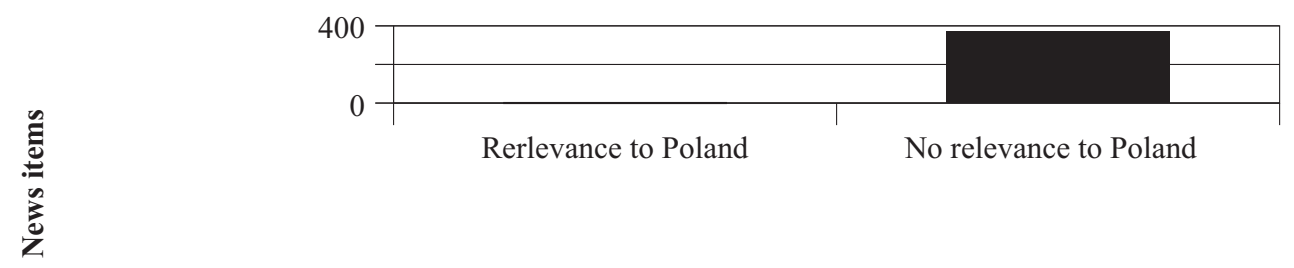

\section{Relevance to Poland}

The portal's dominant topic was economy and the issue of the Greek financial crisis dominated all the news items, even those referring to the Presidency. In terms of the domestication of news, every news item about the Polish Presidency had explicit reference to nationals and to impact on Greece, emphasizing on the actions of the Greek politicians on the sidelines of the EU summits. The attitude towards Poland was neutral, in general, with slight reliance to stereotypes of Poland as an ex-communist country. There were also references to the controversies between the Polish government and the EU about the participation of Poland in the Eurozone summits.

\section{TOVIMA.GR}

The news portal www.tovima.gr belongs to the same media organization with the newspaper "To Vima" and has succeeded in filling the gap in every-day news coverage that has occurred due to the recess of the newspaper's daily printed edition. As a result, the journalists, correspondents and authors of opinions, which are engaged in news coverage, work both for the printed weekly edition and for the daily online edition as well. So the major actors involved as well as the frames and perspectives presented reflect the same opinions as in the newspaper "To Vima".

For the sampling period from June 2011 until January 2012, 364 news items with reference to Poland were posted. Only 10 of them were directly related to the Polish EU Council Presidency (see Figure 4). The rest referred to Poland in terms of commenting on historical facts, cultural and major sports events (i.e. EURO 2012), interviews of distinguished personalities (prime ministers, politicians, authors, athletes, scientists etc.), book and film reviews, technological achievements, agricultural productivity, financial investments, tourism, immigration, criminality etc. So, the most frequent use of the term "Poland" in the texts (both in news items referring directly or not to the Polish Presidency) was the one emphasizing the role of Poland as a new 
EU country, host of a meeting, organizer of an event or as a venue of the meeting-event. In many of the news items, "Poland" was explicitly mentioned in the texts as a post communist country implicitly suggesting some characteristics with negative notion or as a "former" Eastern European country with European orientation and perspectives. In general, the portal's attitude towards Poland was mainly neutral, but there were explicit hints with a negative notion about the role of the country.

Figure 5. Online media: dominant topic

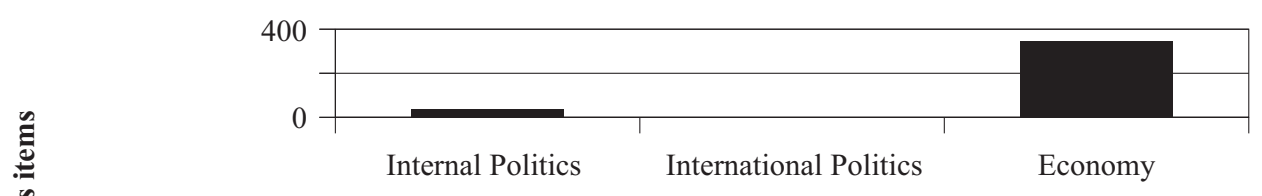

\section{Dominant Topic}

The 10 news items referred directly to the Polish EU Presidency dealt mainly with issues the EU Council and the Euro area Summits, the future of Europe and the Europe, the European financial and identity crisis. A few of them were displayed on the front web page, with a link to a new page. In the framework of the foreign news domestication strategy, their publication was usually followed by other news items, mainly reportages, about the Greek politicians' actions on the sidelines of the EU summits hosted in Poland. Towards the direction of making explicit reference to national and to impact on Greece, the Polish Presidency "inspired" authors to publish their opinions and analyses about the future of Europe and the role of the "big" member-states in the financial crisis. As "Tovima.gr" is a news portal with continuous news flow, many of the news items of the sampling period received comments originated from readers.

In the body of the press releases, the basic frame used is the role of Poland as EU member holding the Presidency for the first time, without any further extensions. Moreover, there are references to nationals and to the impact on Greece. The atti-

Figure 6. Attitude towards Poland

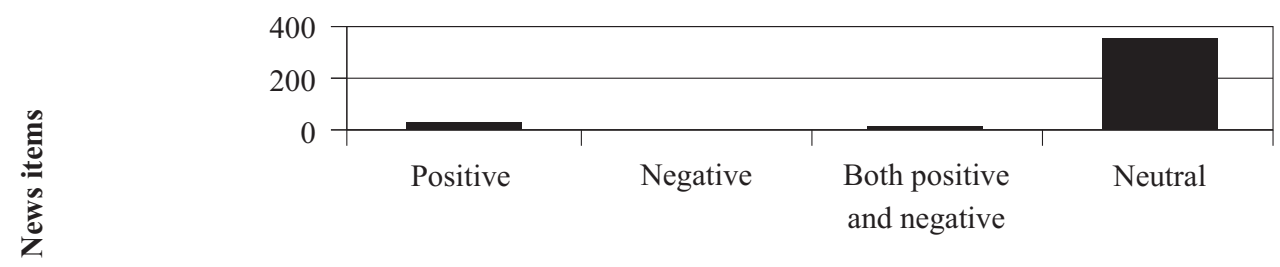


tude towards Poland is neutral, free from any stereotypes and skepticism. The noteworthy thing is that as the newsletter is the official informative bulletin of the European Commission in Greece, it should have included more press releases related directly to the achievements of the Polish presidency and it should have included more events and topics related to that subject.

\section{European Commission's Representation in Greece}

It is worth mentioning that the news items regarding the holding of the EU Council Presidency form Poland were only 3. There was detailed reference to the Polish Presidency only once, on June 30, 2011, announcing the Press Conference organized by the Polish Embassy in Athens followed by an extended text analyzing the scope and the aims and priorities set by Poland. One of the frames used to describe the impact of Polish Presidency on Greece were a press release about cultural events in the Polish Embassy in Athens regarding the "Eastern Partnership", Central Europe and the Balkans, in the framework of the closing of the Polish Presidency, with the presence of the Ambassador Michael Klinger. In this press release there is cultural orientation to the nation with no further encoding symbols or interpretations, just a neutral presentation of the event.

As the newsletter has a different structure and does not use common news formats as the other media investigated in this study (no journalistic structure), the dominant topics vary according to the EU timeliness and informative policy. The source of information is always the same, the European Commission, and the genre of the news items is always the same, press release, with no opinions included or major actors involved.

\section{Newspaper "To Vima"}

During the period from June 15, 2011 to January 30, 2012 there are 56 journalistic pieces referring to Poland, 13 with direct relevance to the Polish Presidency and 44 with no direct relevance to the country (see Figure 7).

Figure 7. Newspaper "To Vima", News items' relevance to Poland

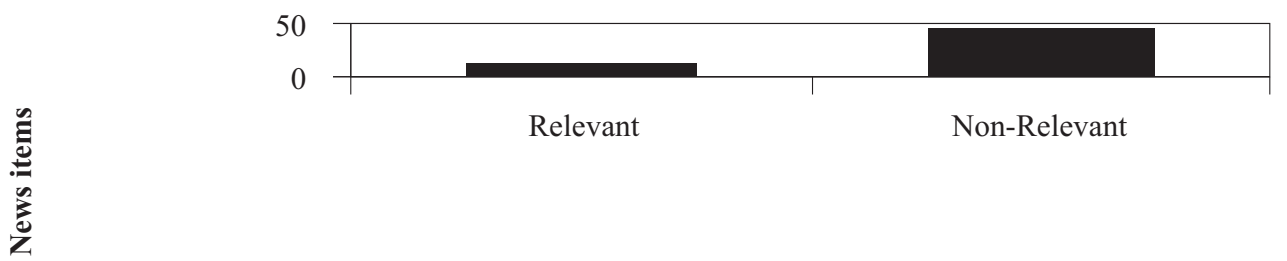


We find the term "Poland" as a country of origin in articles and opinions which discuss literature, art, famous writers, cultural events; as a host country in news items about the EURO 2012 Football Championship; as a venue for the EU, EcoFin and Eurone Summits. The use of the term "Poland" has the meaning of the local definition.

Nevertheless, there are articles and opinions regarding Poland as an ex-communist and Eastern European country, that belongs to the partners and allies of Russia, under a neutral perspective from the newspaper, with some small reliance to stereotypes about the country, but with clear references to nationals and to the impact on Greece. There is also a reportage analyzing the solutions proposed for the exit of Greece from the financial crisis, with special reference to the development of the Greek touristic sector, as a financial "relief" for Greece and with relevance to Poland. Moreover, there are articles (very few) referring directly to the Polish Presidency under a very positive perspective and attitude (see Figure 8).

Figure 8. To Vima's attitude towards Poland

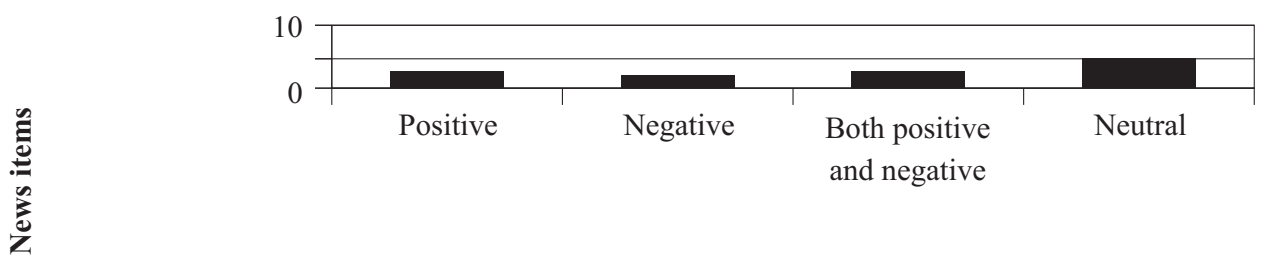

\section{Attitude towards Poland}

It's worth mentioning that the newspaper published interviews from foreign experts, analyzing the role of Poland as a new EU member and a post communist country, in an effort to expunge the stereotypes surrounding it. Additionally, the newspaper gives emphasis on Poland's priority to help the EU in its efforts to manage the debt crisis threatening Greece and the Eurozone. Within the framework of political orientation, great importance is given to the "Eastern Partnership" between Poland and other Eastern European countries dealing with the issue of the European identity crisis, seen under a positive perspective and attitude.

Figure 9. Dominant topic of newspaper "To Vima"

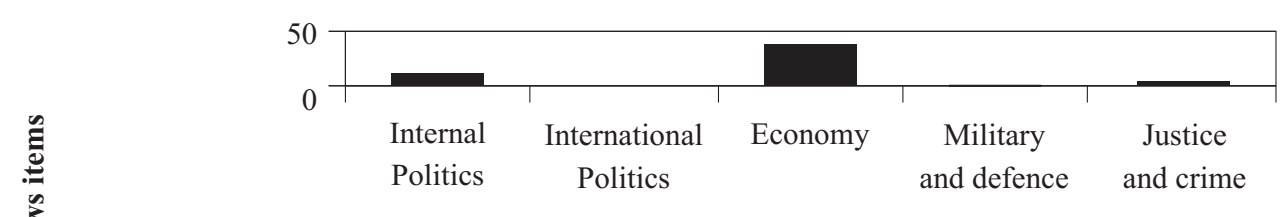


Economy and issues related to the Greek financial crisis dominated the newspaper's front pages, some of them strongly related to the events that took place in the EU summits in Poland, leaving far behind issues regarding internal politics.

\section{Conclusions}

The survey reaches the conclusion that the coverage of the Polish EU Council Presidency in Greek media was not satisfactory and proportional to the range and significance of such an European issue. The six months of the Polish Presidency of the European Council, although it may have been the most difficult period in the history of the project due to the Eurozone crisis, did not appear much in the news coverage in the Greek media investigated.

The coverage of EU issues in the news flow in Greek media - regardless the direct reference to the accomplishments of the Polish Presidency was in general high due to the fact that all these issues included explicit reference to nationals and to the impact on the country as they were strongly connected to the severe financial crisis in Greece. So, the element of the domestication of foreign news, along with the elements of foreign news values and valuation attitude towards Poland, affected the Greek media's criteria of selection of events taken place in the EU to become news items and play a key role in the Greek media agenda setting. Due to the fact that the Polish Presidency coincided with the climax of the financial crisis in Greece, the Greek media focused their attention to the coverage of EU news directly connected to that subject and its impact in the European Union and the Eurozone. Noteworthy is the fact that the Greek media covered with details only the official opening and the expiry of the Polish Presidency of the EU Council. Afterwards, the informative focus has shifted to the financial crisis.

Given the research findings, the news coverage of the Polish EU Council Presidency was not similar in printed edition, online edition and television. The newspaper "To Vima" and its online edition and portal, "Tovima.gr", were found to have the major proportion of EU news and news about Poland. Although public television is supposed to have a high coverage on EU news, due its informative mission in favor of the public, in the said study it was proved to have broadcast a small amount of news referring to the Polish Presidency. The same is obvious and on the Greek state television portal, "ert.gr", which is supposed to post EU more detailed news items and more frequently, as it has a continuous news flow. On the contrary, ert.gr posted very few news items about the Polish Presidency and all the others with reference to Poland had nothing to do with the Presidency itself. Along with the small amount of news items, we observed a sparse frequency in broadcasting news about the Polish Presidency.

As far as the news items' reference to Poland is concerned, the majority of them was not related directly to the Polish Presidency and was under the sections "Economy", "Politics" and "Opinions" and "Sports" (mainly related to the hosting of the 
European Foot ball Championship EURO 2012). So the events that attracted the Greek media's attention had no relation to the Presidency and the picture that the Greek audience drew was Poland as a host/venue of important events, with connotation to Poland.

In relation to the sources of information, the newspaper "To Vima" is supposed to have correspondents and staff specialized in foreign news, but in many cases the newspaper uses the Athens News Agency - Macedonian Press Agency (national news agency) without mentioning that source of information. Moreover, although the public television's portal is supposed to have staff expertise in the area of international news, the main source of information is the Athens News Agency - Macedonian Press Agency (national news agency). The national news agency is used by all media investigated, except from the European Commission's Representation in Greece. As a result, the reporting language is almost similar in the news items of different media organizations and this leads to similar comments and interpretations of the news items' meanings.

In terms of the domestication of foreign news, the strategy used in order to make the events of the EU Polish Presidency relevant for the Greek audience, was to make explicit reference to Greece and to the impact on the country. Along with the aforementioned strategies goes the Geek media's tendency to focus mainly on politicians and other national actors when they covered news regarding European matters. When attention was paid to the news about the Polish EU Council Presidency, it is usually in connection with national political leaders, parties or national issues, while the rest of the EU issues are often pushed aside. So the domestication strategy of the Greek news organizations confirmed one of the main parameters of the agenda-setting process: Which aspects of an issue are covered in the news, and the relative emphasis on these various aspects of an issue makes a considerable difference in how people view that issue.

The comparative research brought to the surface the low visibility of Poland in news coverage in Greece, which was accompanied by a generally neutral attitude that enhanced the low recognition of the former by the latter. So, the general attitude towards Poland was neutral and in some cases positive emphasizing on the fact that it was an opportunity for Poland to change the notion of the post-communist country. It was a positive framework into which they presented Poland as a new EU member and as a new notion in the "European family". There were some hints about the country's ex-communist "past", indicative of some media's skepticism, but the general notion was not negative. Many of the news items, except form opinions and commentaries, reflected the journalists' skepticism about the role of Poland holding the Presidency. Other news items tried to remove stereotypes that have been implanted in the Greek public opinion perceptions. The most frequent use of the term "Poland" in the texts (both in news items referring directly or not to the Polish Presidency) was the one emphasizing the role of Poland as a new EU country, host of a meeting, organizer of an event or as a venue of the meeting-event. In many of the news items, "Poland" was explicitly mentioned in the texts as a post 
communist country implicitly suggesting some characteristics with negative notion or as a "former" Eastern European country with European orientation and perspectives. Let's not forget that according to each country's political culture, the national media use related frames and perspectives while reporting foreign events.

To sum up, the Greek media paid not as much attention as they should in the Polish EU Council Presidency, as the Polish EU Council Presidency coincided with the climax of the severe financial crisis in Greece. Undoubtedly, that fact played a significant role in the construction of the Greek media agenda-setting and in the information process as well. As a result, the Greek media focused their attention to the coverage of the Greek economic crisis and its impact in the European Union and the Eurozone. In other words, the Greek media got engaged in a perpetual effort to inform Greek audience with all the current developments on the crucial subject of the future of Greece in the European Union and to fulfill their mission as gatekeepers in the information process. And that lead us to the final remark that the Greek public opinion did not obtain a complete picture of the Polish Presidency key achievements. Furthermore, that low visibility and recognition of Poland in Greece led to low expectations towards the country that was in the helm of the EU Council and had the unique opportunity to exploit the advantages that derived from its advanced position in the EU. The agenda setting practices of the media organizations in Greece influenced the perceptions the Greek public opinion has on Poland and on the valuation of the Polish Presidency. So, the neutral reporting of Poland or the highlighting of an issue regarding the Polish Presidency more than another, contributed to the formation of neutral perception towards the country. In conclusion, as far as Greece is concerned, the Polish EU Council Presidency did not succeed in attracting the Greek media's attention as an actor-in-charge of the European Council and as the title implies, "the call" from Poland was not sufficiently "forwarded" to Greece.

\section{References}

Bruter, M. (2004), “On what citizens mean by feeling 'European’: perceptions of news, symbols and borderlessness", Journal of Ethnic and Migration Studies 30(1), 21-39.

Clausen, L. (2003), Global News Production, Copenhagen: Copenhagen Business School Press.

de Vreese, C. H., Peter, J., Semetko, H. A. (2001), "Framing politics at the launch of the euro: A cross-national comparative study of frames in the news", Political Communication $18,107-122$.

de Vreese, C. H., Boomgaarden, H. G. (2006), “Media Message Flows and Interpersonal Communication: The Conditional Nature of Effects on Public Opinion", Communication Research 33(1), 19-37.

Fuller, J. (1996), News Values: Ideas for an Information Age, Chicago, IL: University of Chicago Press.

Harcup, T., O'Neill, D. (2001), “What is news? Galtung and Ruge revisited", Journalism Studies 2(2), 261-280. 
Galtung, J., Ruge, M. (1965), “The structure of foreign news”, Journal of Peace Research, Vol. 1, 64-90.

Jochen, P., de Vreese, C. H. (2004), “In Search of Europe: A Cross-National Comparative Study of the European Union in National Television News", The Harvard International Journal of Press/Politics 9, 3-24.

Loffelholz, M., Weaver, D. (eds) (2008), Global Journalism Research: Theories, Methods, Findings, Future, Malden, MA: Blackwell Publishing.

Machill, M., Beiler, M., Fischer C. (2006), “Europe-Topics in Europe's Media: The Debate about the European Public Sphere: A Meta-Analysis of Media Content Analyses", European Journal of Communication 21(1), 57-88.

McKane, A. (2006), News Writing, London: Sage Publications.

McQuail, D. (2003), McQuail's Mass Communication Theory, London: Sage Publications.

Mughan, A., Gunther, R. (2000), “The Media in Democratic and Nondemocratic regimes: A Multilevel Perspective", in: A. Mughan, R. Gunther (eds), Democracy and the Media. A Comparative Perspective, Cambridge: Cambridge University Press, 1-27.

Norris, P. (2000), A Virtuous Circle: Political Communications in Post-Industrial Societies, Cambridge: Cambridge University Press.

Peter, J. (2003), Why European TV News Matters, Amsterdam: University of Amsterdam.

Peter, J., Semetko, H. A., de Vreese Claes H. (2003), “EU Politics on Television News: A Cross-National Comparative Study", European Union Politics 4(3), 305-327.

Peter, J. \& de Vreese Claes H. (2004), “In Search of Europe: A Cross-National Comparative Study of the European Union in National Television News", The Harvard International Journal of Press/Politics 9, 3-24.

Potter, D. (2006), Handbook of Independent Journalism, U.S. Department of State, retrieved from http://www.america.gov/publications/books/handbook-of-independent-journalism.html.

Prior, M. (2005), “News vs. Entertainment: How Increasing Media Choice Widens Gaps in Political Knowledge and Turnout", American Journal of Political Science 49(3), 577-592.

Semetko, H. A., de Vreese, C. H., Peter, J. (2000), “Europeanised politics - Europeanised media? European integration and political communication", West European Politics 23(4), 121-141.

Trenz, H-J. (2004), "Media Coverage on European Governance Exploring the European Public Sphere in National Quality Newspapers", European Journal of Communication 19(3), 291-319.

Nielsen Television Audience Measurement, available at: http://www.agbnielsen.com/ whereweare $/$ dynPage.asplang=local\&id=248\&country=Greece, accessed: January 31, 2012.

“The Greek Newspapers' readership during the 2nd semester of 2012", in: Marketing Week on line, http:/ / www.marketingweek.gr/?pid=9\&arID=42235\&la=1, accessed: January 31, 2012.

Alexa, the World Information Company, available at: http://www.alexa.com/searchq= tovima.gr\&r=home_home\&p=bigtop, accessed: January 31, 2012. 

Valentina Marinescu, Mădălina Bălăşescu

University of Bucharest, Romania

\section{The Romanian Press and European Issues: A Content Profile}

\section{Introduction}

In his analysis of the journalistic activity, Stephen Reese (1997:423) claimed the existence of a true paradigm of journalism: journalism is an activity of collecting empirical information, in which various activities have developed. In the absence of clear theoretical frameworks, journalists rely heavily on routine procedures as a "strategic ritual" which helps them to cope with the pressure of the dead-line. The routine is very important because it involves threats of the paradigm. With the increasing professionalization attributes, the features paradigm were accentuated. In this way, the paradigm of journalism can be seen as a model that governs the collection of information, revealed through practical journalism and centered on the evaluation criteria of the journalistic potential an on the ways of their transmission to the public. Seen as an ideology, the paradigm of news is thus marked by numerous contradictions: between the values derived from the existing diversity of the viewpoints in an editorial board and the values of the objectivity in the practice of data collection. In this context, the news can be analyzed from several perspectives: (1) a professional size (rules, procedures and professional values); (2) an organizational dimension (the news as a chain of production which must be organized so as to deliver and sell more products on a highly competitive market); (3) a social dimension (news are perceived as carrying an ideology). The three levels of news analysis distinguish between "actors" who produce news (the journalists and the organization) and the "results" of this process (content, news messages and their meanings) (Reese, 1997:420-437).

The study therefore tried to validate (or invalidate) in an empirical way the following research situation: How can the existing organizational and professional variables in the field of professional journalists explain the covering level of the EU processes and events in the online and print Romanian media? For this purpose, a content analysis was conducted on a sample of articles published in newspapers and online Romanian media between June 2011 and August 2012. Professional and organizational variables have been quantified, based on the typology proposed by Pan and Kosicki (1993:55-76), for each material analyzed, namely the typology of actors and the attributes of the narrative news proposed by them. 


\section{A review of the literature}

\section{The selection of the information}

Why do journalists choose certain words, certain people, certain actions of a virtually infinite universe of information and meanings? What are the mechanisms that occur in devices called media which highlight some facts and ignore others? Is there a logical selection and rationalization in this process? Answers are provided by psycho-sociological, economic and cultural theories (Golding, 1974; Schudson, 1978; Mouillaud \& Tetu, 1989; Van Cuilenburg et al, 1998; Allan, 1999; Sorlin, 2002). After Van Cuilenburg (Cuilenburg et al, 1991:184-192), the individual dimension of the analysis corresponds to the "micro-level", the organizational dimension to a "middle level" and the social dimension is reflected in a "macro-level". The individual analysis of the selection behavior has a strong subjective dimension, supporting the idea of the high degree of randomness in the choice of happenings with media value.

The idea is supported by a number of researchers. Some of the most relevant research in this regard are the gate-keeping studies, highlighting the most subjective aspects of how the happenings selection. Kurt Lewin argued that any information that reaches to the public passes "through many gates" guarded by groups and decision makers which "close" or "open" according to their rules. In his opinion, the first level of the access to the media zone belongs to the reporters and correspondents, and the last "chance" of the information to gain access to public accents is the "editor" who has the final say on messages to/from the media (Lewin \& Schudson, 1997:8).

Within the same context, D. M. White identified four categories of reasons seemingly "frivolous" of the rejection of news (White, 1949 in Berkowitz, 1997:70-71): (1) the news had been selected by another agency, (2) lack of space, lack of processing time, (3) the belief of the editor that the news was not interesting to the public, (4) the news was incomplete. The author thus shows that the selection of news was a process based primarily on value judgments, on personal experience and arbitrary attitudes. He also shows that the reasons underlying the selection of news have a large dose of ambiguity, and the public learned about certain facts just because the journalist himself decided on the selection of the news that should become public.

Other authors show that not always the individual factors affecting the news depend on journalists. In this respect, Maletzke identifies two categories of factors influencing the individual selecting of the information (Van Cuilenburg, 1991:181-182): (1) "dependent" factors (personal preferences of the journalist, his own value system, the image of himself as a journalist and the profession of journalism, education, gender, how to understand the audience); (2) "independent" factors (profile of the institution, the economic status of the organization, the system of technical stan- 
dards for the collection and dissemination of news, the social, political and legal environment in which the organization operates).

The level of organizational analysis of the selection mechanism shows that media production is a collective act that happens in an organizational structure. Many analyzes have that the economic understanding of the process of creating news is a more realistic way to explain the professional culture (Fishman, 1980; Mathien, 1992; Bantz, 1997; Shoemaker, 1997; Schudson, 2003). The economic understanding of the production activity goes beyond the paradigm of the individual factors as a basis for the selection behavior. According to the theory of news as " organizational merchandise", the bureaucratic organization plays a more important role than the individual, considering the news as goods (Schudson, 1997:14).

Also, according to organization theorists, it doesn't matter who journalists are and where they come from, because they will inevitably be "seized" by the organizational culture (values and practices) that will make them employees able to produce texts appropriate to the organizational requirements. The organizational explanations of the selection of the information relate the professional behaviors relate to the economical logic, underlining the characteristic of "merchandise" of the news and the importance of the bureaucratic criteria in choosing happenings. Therefore, from an economical perspective, journalists are marked by the need for continuous flow of information, which justifies the major influences of the organizational culture in "labeling" facts and building selection sets on information.

Most studies have emphasized the general idea that the organizational elements determine directly the journalistic decisions (Bantz, 1997; Fishman, 1980). The economical values of the media content as "merchandise" are to be found in the professional culture, as Mark Fishman (1980:146-150) said, at the level of some important work categories such as: (1) dead-line sites (product should be delivered in time for the client to trigger stereotypes consumption); (2) areas dedicated to the content (regardless of the amount of "reality", spaces that must be filled and will be filled remain constant); (3) the need for planned events (press conferences, round tables, seminars, and so on, types of convenient events for journalists and effective for the organization). M. Fishman (1980) considers journalists subordinated to the institutional logic, supporting their conformity to the idealization and conventions of the institution for which they work. He also places journalists in another convenient convergence, including the "producers" of planned information who influences paradoxically on the journalistic work, based on the organizational requirements.

\section{External factors that affect professional routine}

P. Shoemaker and St. Reese speak of the seven categories of factors "extramedia" that structure the media routine (Shoemaker \& Reese, 1996:184-219): (1) the location of the media organization is related to "retail market", which is marked, in turn, by factors such as economy, culture, social and physical settlement; (2) the interest 
groups trying to influence the content of messages, providing journalists "guide lines" through lobbying and public relations campaigns; (3) the target audience: advertising sales and media organizations provide a profile of the audience for which journalists write; (4) the government has a demonstrated tendency to interfere with the work of the media; (5) the competition, especially global competition, plays an important role in the regulation of the content; (6) the institutional links: most often, the media are related to financial institutions and depend on the resources of other institutions part of the corporation to which they belong; (7) the technology has contributed to media revolutions.

Extramedia factors influence these media activity in many ways: (1) sources which understand exactly the work of the practices routine are the most likely to enter the media space; (2) news writing is influenced by economical or political power of the source; (3) advertising clients have a direct influence on the number of pages of the editorial content; (4) the audience interest easily determines a mimetic behavior of news producers, harmonizing public messages; (5) community characteristics influence messages.

\section{The ideological dimension of news: the media and the public agenda}

The news production is influenced by organizational variables and professional variables (professional norms, individual and professional values). Whether individually or as part of a group, professional values adapted to the requirements of society and ideology can be found in the institutional, occupational and cultural practices composing the media. The media content no longer appears as an 'isolated', but as a deeply social product, organizationally determined. Occupational routines relate to broader ideological needs. The media is a body of work relevant for understanding the nature and the importance of content effects on people and society (knowing the media, content, its effects on the audience can be predicted). Maxwell McCombs (2004) widely considered the problematic role of the media in creating public interest topics. According to his analysis, the most important aspect of the role of public agenda of the media is to influence public opinion, and his argument is based on several elements. First, the themes that capture people attention are known through newspapers, not through personal experience. Secondly, the news function as a signal, a central element of this theory, alerting people on the latest developments in the near or more distant environment. Third, journalistic content, resulting from specific rules of selection and packaging, directs public attention and influence the perceptions of individuals.

\section{Sources}

The journalist finds himself between the organization and the information, adopting a number of strategies to establish, maintain and develop his sources of information. Remy Rieffel was talking about a true "swing" of power in this regard, arguing that journalists develop in a long term a true "network" (Rieffel, 1994:62). Most studies 
that have attempted to outline professional imagery on sources are numerous and show a consistent relationship between journalists and sources over time in different spaces. Theoretically, the relationship with sources "support" a series of standardization, from source categories to ethical rules of networking with sources, constituting an important element of the journalists' "routine" system. Case studies, especially American ones, indicate a common sense approach to journalists' sources, which shows evidence of a common professional framework in this area of professional practice. The uniformity of reporting to sources may be a result of an extraordinary importance that has this aspect of practice as a whole. Beyond the meanings of messages, the content routine is very clear: the information assumes various forms and formats, which are based on certain principles of reporting, prioritization, selection, drafting. Mostly, they are determined by the exigencies of perception. The journalistic "story" is largely the result of a series of routine procedures. How reality can not always be subject to those rules, that explains some forms of distortion of reality.

\section{The media event}

The way organizations define events also emphasizes the importance of organizational planning ideas. According to Lester and Molotoch, there is an obvious lack of spontaneity of the media effort to watch the world around, suggesting that "reality" is nothing but a kind of conceptual "labor" (journalists, organizations and sources) through which events are created. In this process, with so many "reconstructive" interventions, objectivity is out of the question, as news appear as reflections of social and individual actors, taken by journalists and then subjected through organizational filters (Molotoch \& Lester, 1997:200-205). Event criteria or "tags" that journalists use to define events are no other than conventions meant to put in order a supersaturated informational reality. Leo W. Jeffres (1986:106-108) reminded of two sets of conventions, both sets having functional roles. The first set is about objective rules of the professional culture: the timeliness and proximity of the event, bringing the overall progress events, disasters, prominence of the personalities involved, the potential for conflict, the dramatic potential of the event, the consequences it involves, the human interest. The secondary set of conventions include: frequency and intensity, ambiguity, ability to signify, consonance, unpredictability, elitist dimension applied to nations, personalization factors, negative nature of the story.

\section{The study}

\section{The hypotheses}

In developing working hypotheses, a research question is taken into consideration: "How can the existing organizational and professional variables in the field of pro- 
fessional journalists explain the covering level of the EU processes and events in the online and print Romanian media?".

We were primarily concerned to identify relevant articles and news coverage in Romanian newspapers and online media of the Polish Presidency of the EU in the period June 2011-July 2012. We expected that dominant themes related to Poland to be covered in a significant way by Romanian offline and online media, particularly regarding their informational dimension. We proposed the following hypothesis: H1. There is a higher probability that the Romanian media coverage of the Polish Presidency of the EU be realized in informative articles and news stories, opinion articles on the subject being published in a much lower number in the analyzed period of time.

In our opinion, for the analyzed period of time, the types of information regarding Poland, presented by the Romanian media (newspapers and online) will be very different. On the one hand, both countries (Poland and Romania) are new members of the European Union and, hence, the informations about the evolution of the political system and economical and social areas in Poland is likely to be of interest to journalists and the public in Romania. On the other hand, the Polish Presidency has covered a year, a time when both countries were likely to have to face socio-economic challenges due to the global recession. Considering both aspects previously mentioned, the study examines the existing proportion between purely informational aspects and elements derived from the opinion of journalists, as they were identified in the news and articles published in Romanian newspapers and online media.

As literature recognizes (Rieffel, 1994:62), when an article or a news appears in the media, only the journalist's idea to make a material or reflection or to report a material exists before the information provided by sources. After the idea, sources "are" virtually materials producers, they grove the approach angle, they stress or not a certain information, driving it erratically in public or simply sending "test balloons" through journalists. Given the role of the "map" of the sources in the production of articles and news and its relation to the journalists' professional imaginary, we have proposed the second research hypothesis: H2. There is a higher probability that the sources used in the Polish EU Presidency coverage be international news agencies, national sources having a lower weight in the news and/or articles in the Romanian media.

The literature (Molotoch \& Lester, 1997:200-205) distinguishes between three categories of events presented by the media: (1) routine events; (2) accidents; (3) scandals. Molotoch and Lester show that the existence of three types of events is an indicator of the centrality of the organizational planning in the activities of media organizations. Also, the inclusion of an event in a certain class endorses organizations regarding the events codification made by journalists. Starting here, we had as the third research hypothesis the following statement: H3. There is a higher probability that the events on the Polish EU Presidency be routine events, accidents and scandals regarding Poland being types of events to be covered to a lesser extent in the Romanian newspapers and online media. 
Referring to the work of journalism, Leo W. Jeffres (Jeffres, 1986:106-108) differentiated between objective standards of professional culture on the one hand, and elements derived from the very specific events presented by the media. We considered that we can identify professional and organizational variables that are functional in Romanian media at the level of the second set of criteria theorized by Leo W. Jeffres (idem). Specifically, in our opinion, the Polish presidency of the European Union should be submitted by Romanian journalists by focusing on the elitist dimension applied to Poland's role in the European context (by enhancing the quality of Poland's EU presidency in the period of time under review), on the ability of giving meaning to the new role of Poland (in Romania the public was familiar with both Polish and the the EU socio-economical and political issues, which has a clear relevance for the Romanian audience) and on the positive consonance (any event regarding Poland during the Polish Presidency of the EU will be in accordance with the positive expectations about this country).

From this, we continued with the following research hypotheses: H4. In the analyzed period of time, there is a higher probability that the image of Poland in the Romanian media be positive, neutral presentations being published in a smaller number of items during this period. H5. There is a higher probability that the coverage of Poland as a full member of the European Union be raised in the articles and news published in Romanian newspapers and online media. H6. There is a higher probability that the topics covered in the articles published by the Romanian media, referring to Poland's foreign policy activity, issues related to the economy, domestic politics, culture or sport, be covered to a lesser extent in the period under review.

\section{Dataset and methodology}

To meet the requirements of the "methodological triangulation" and validity of the data we used as the main method of data collection the quantitative content analysis. The analyzed sample included a selection of newspapers and online media from Romania. Media in Romania were elected accordingly to market shares as they were registered off-line and on-line (The Romanian Office of Traffic Audit). We chose 9 Romanian media: six newspapers - "Adevarul" (The Truth), "Jurnalul National" (The National Journal), "Romania Libera" (The Free Romania), "Libertatea" (The Freedom), "Click" - three general sites- Ziare.com, Hotnews and EurActiv - and a weekly magazine - "Revista 22" (22 Review). The analyzed period included twelve months covering the period June 2011-August 2012. In the sample all items relating to Poland were included. The final sample result had a volume of 2715 articles, that is 1668 articles published in newspapers and 1047 more articles presented online.

Regarding the distribution of articles according to the considered media, the sample was structured as follows: "Romania Libera" (Free Romania) - 410 articles, "Jurnalul National" (National Journal) - 288 articles, "Libertatea" (The Freedom) - 34 articles; "Adevarul" (The Truth) - 834 articles; "Click - 25 articles; Hotnews 
- 571 articles; Ziare.com - 398 articles; EurActiv - 78 articles; Revista "22" (22 Review) - 77 articles. To test the inter-coders reliability for the entire study sample, we chose Cohen's Kappa index - (k). The values of $k$ for the variables of the sample of articles published in newspapers ranged between 0.442 and 0.3117 . The values of $\mathrm{k}$ for the variables of the sample of articles published in online media ranged between 0.467 and 0.387 . For the analysis of data we use both descriptive statistics (frequencies) and inferential statistics (logistic regressions).

\section{Findings and analysis}

The EU Presidency was presented by $16 \%$ of all articles published in newspapers referred to Poland and by $36 \%$ in the sample of articles published on the same issue in the Romanian online media. From the perspective of the type of writings, news stories covering the Polish Presidency of the EU accounted 18\% for newspapers and $39 \%$ for the online media, the editorials amounted to $29 \%$ for newspapers and $33 \%$ for the online media, and comments published on this topic in the sample represented $42 \%$ of newspaper articles and $24 \%$ of online media. After reading this primary data set, it is obvious that the first research hypothesis was not empirically validated - namely, the Romanian media coverage of the Polish Presidency of the EU was achieved to a greater extent in articles and news of opinion (editorials and comments), press material such information being in a smaller number for the entire sample considered.

The statistical modeling not only gives us some explanation of this situation, but also allows us to identify some differences between newspapers and online media. Thus, the model for newspapers has been from the beginning a strong one, the news published on the front page explaining with a probability of $15 \%$ the coverage of the Polish EU Presidency. Also, a photo attached to an article grew by $21 \%$ the probability that this news is about the Polish Presidency. Regarding the dominant themes, the most explanatory power was recorded for subjects related to sports coverage $(34 \%)$ and international political life (26\%). For the online media, an iterative procedure was required, the differences between the two models indicating a lack of explanatory contribution to the position of the news on Polish Presidency on the first page of the website or to the attachment of a picture next to the article.

However, publishing a photo with the article explained $10 \%$ of the coverage in online media of the Polish EU Presidency. And this time "sport" was the dominant theme and the variable with the greatest explanatory power $(18 \%)$, followed by the "economical life" - there is a 13\% probability that the news published on the subject explain coverage in the Romanian online media of the Polish EU Presidency. The role of the journalist is evident in the case of the statistical model on the news published in newspapers (there is a $18 \%$ probability that a journalist from the editorial board sign a story about the Polish Presidency of the EU), but there is a total lack of explanatory contribution in the online media (the journalist from the editorial board 
signing news about Polish presidency downs, in fact, the strength of the whole model).

The analysis of the coverage of the Polish Presidency of the EU in the Romanian media from the perspective of the quoted sources indicate a predominance of domestic over international sources. Thus, $13 \%$ of articles published in newspapers quoted Romanian national news agencies (compared to only $7 \%$ of them having quoting international news agencies), while $48 \%$ of the articles published on this topic in the Romanian online media quoted national news agencies (compared to only $30 \%$ of the sample online media that quoted international agencies). Statistics indicate thus the invalidation of the second working hypothesis - the sources used to cover the Polish EU Presidency were primarily national news agencies, international agencies were quoted in a lesser degree for the subject. Consequently, the developed statistical models had different behavior - specifically, they were statistically robust and consistent as explanatory power for newspapers and relatively uneven and dispersant for the online media. We could still see a number of similarities in the explanatory factors for newspapers and online media.

For the quotation of the international news agencies the fact that the journalist is a member of the editorial news office explained significantly ( $6 \%$ for newspapers and $10 \%$ for online media) the coverage of the Polish EU Presidency in the articles. From the perspective of national news agencies quotation, the journalist belonging to the editorial staff will increase by $8 \%$ - newspapers - and by $10 \%$ - online media - the probability of an article referring to the Polish Presidency of the EU. In the same explanatory direction acted the themes related to the international politics. More precisely, it is more probably with $20 \%$ that newspaper articles approaching international politics quote international news agencies.

However, the probability that online media articles having topics of international politics quoting these news agencies refer to the coverage of the Polish Presidency of the EU is $8 \%$. The explanatory contribution of the theme "international politics" in explaining variations in articles and news on this Polish EU presidency quoting national news agencies remain high for newspapers - $15 \%$ - but weak - only $5 \%$ - for online media.

The third research hypothesis ("There is a higher probability that the events on the Polish EU Presidency be routine events, accidents and scandals regarding Poland being types of events that will be covered to a lesser extent in the Romanian newspapers and online media") has been confirmed by empirical data set - both in the newspapers and online media in Romania. Thus, $2 \%$ of the articles and stories that presented the Polish Presidency of the EU in the papers covered topics related to scandals and criminal justice while only $1.5 \%$ of articles published in online media presented these topics and only $1.5 \%$ of articles and news published in the online media have covered the topic of accidents and disasters.

Beyond descriptive statistics, logistic regression models developed showed both similarity of the explanatory factors for newspapers and online media and their robust suitability to data. The most significant contributions to the likelihood that cov- 
erage the Polish EU Presidency to achieve through routine events came from the variables derived from the particular topics covered by these articles and news. Presentation of international political organizations activity resulted in an increase of $37 \%$ in the Polish EU Presidency relevant covering in articles published in newspapers and one of $44 \%$ for this cover in online media.

Coverage of individual politicians activity as a particular theme explained in a relevant proportion of $16 \%$ the Polish Presidency relevance in the papers and in a proportion of $21 \%$ in its coverage of the online media. The particular theme of "diplomatic negotiations" increased by $17 \%$ the Polish Presidency topic coverage in the Romanian newspapers and by $22 \%$ in the media items online. The coverage of budget issues explained in the proportion of $14 \%$ the variation in the relevance of the Polish EU Presidency in the articles in newspapers and in the proportion of $16 \%$ this variation for news and articles in the online media. The last common explanatory variable - covering specific issues of the economic crisis - explained in the proportion of $20 \%$ the variation in newspaper articles dedicated to the Polish EU Presidency and in the proportion of $11 \%$ the variation in the presentation of this presidency in Romanian online media.

Poland was positively presented in $23 \%$ of Romanian newspapers articles and news covering the country's EU presidency (but $69 \%$ of press material contained in this sample presenting it in a neutral way), while $36 \%$ of articles published in newspapers and online media on the same subject had a positive perspective (compared to $40 \%$ of the online sample that presented in a neutral way the Polish EU Presidency held during the year under review). It is thus evident that, at the pure statistics descriptive level, the fourth research hypothesis has not been validated by empirical data. The presentation of Poland in Romanian media was mostly neutral in articles covering EU presidency, positive presentations being published in a smaller number of items in the analyzed period. The explanation for this result lies in the different statistical behavior of the variables included in the explanatory models developed. There was a of $15 \%$ for the online media (and of only $5 \%$ for newspapers) that the publication of news relate positively to the Polish Presidency of the EU.

Meanwhile, quoting international news agencies as sources of articles increased by $14 \%$ the probability that the presentation of the Polish Presidency in the papers be positive. Quoting the same international news agencies explained $18 \%$ of the variation in the presentation of the Polish EU presidency in the online media. In the case of opinion articles, explanatory models indicate a similar contribution as a statistical strength concerning the question of international news agencies for a positive coverage of the Polish Presidency - 14\% for newspapers and 20\% for online media items.

Beyond these similarities the differences within patterns of logistic regression models indicate a number of differences in the positive coverage of Polish Presidency of the EU in Romanian newspapers and online media. The explicit reference to national has a low explanatory value for the newspapers (only 7\%), but contrib- 
utes strongly - by $39 \%$ - to the variation of positive news about the Polish EU Presidency in the media. Simultaneously, as an alternative model, the explicit reference to the impact of the news on the country explains a $46 \%$ increase in positive news newspaper published about the Polish Presidency of the EU (the explanatory intake of the variable in the online media is much lower - of only $5 \%$ ). And this difference between variables is maintained in the case of opinion articles depending on the nature of media: newspapers vs. online. Explicit reference to the national has a high explanatory value for positive coverage of the Polish Presidency of the EU in opinion articles published in online media (36\%) and a minimum value related to review articles published in newspapers (only $6 \%$ of the total variation in this set of articles).

In contrast, explicit reference to the impact on the country explained $46 \%$ positive increase of opinion articles on Polish Presidency published in newspapers (the similar model built for the online media is not statistically adequate). A journalist being member of an editorial news board is a strong constant variable for newspapers, but its contribution is unstable in explanatory statistical models developed for the online media. For positive news published by newspapers, the membership of the journalist explains by $17 \%$ the variable proportion of positive coverage of the presentation of the Polish Presidency, the percentage was only $7 \%$ for online media. For opinion articles, logistic regression models indicate however a "strip" of the explanatory intake, which is relatively similar for both online media and newspapers. The journalist being member of the editorial board explains in a proportion of $13 \%$ the positive increase of opinion articles published in newspapers covering the Polish Presidency, but the percentage is $18.8 \%$ for the same type of media articles published on-line.

A high percentage (86\%) of the articles on the EU Polish Presidency referred to Poland as a full member of the Union (and only $5 \%$ of the sample material published in the newspaper referred to Poland as a new EU member). And in the case of $63 \%$ of the sample of articles published in online media during 2011-2012, Poland was associated with the quality of a full EU member countries (only $12 \%$ of articles published on-line associated Polish Presidency as a "host a meeting"). Descriptive statistics confirmed, this time, the fifth research hypothesis, it is obvious that the coverage of Poland as a full member of the European Union was clear in the articles and news published in Romanian newspapers and online media in the period June 2011-July in 2012.

Beyond this primary reading, logistic regression models indicated the existence of both e similarities and variations between online media and Romanian newspapers. The fact that the author is a member of the editorial journalistic staff explained in the proportion of $16 \%$ the increase of opinion articles for Poland as a full member of the EU and EU President country, published by newspaper and explained $40 \%$ of the increase in the number of opinion articles with same references (full EU membership and EU president) of online media. There was a $17 \%$ probability that a newspaper article quoting international news agencies refer to Poland as Presi- 
dent of the EU and member state and the explanatory contribution of quoting international news agencies at the model developed for the online media was of $29 \%$.

For the explanatory models derived from the fifth hypothesis, differences between newspapers and online media were, however, significant. The fact that the analyzed material was informative ("news") explained the variation in reference to Poland as a full member of the EU with only $16 \%$ for online media, the explanatory contribution of the editorial informative input being of only $7 \%$ for articles published in newspapers referring to the Polish Presidency of the EU. Coverage by opinion articles in newspapers explained a proportion of $89 \%$ of variation reference to Poland as a full member of the EU, compared to a contribution of the same explanatory input of the same editorial type ("opinion article") of only $7 \%$ for the online media.

The analysis of logistic regression models built with a different set of explanatory variables (the dominant themes in articles and news plus explicit reference to the impact on national or country) revealed another set of differences between online media and newspapers. Thus, all models made for sample articles on the quality of a full EU member Poland published in online media were statistically unstable. For newspapers, on the contrary, the explanatory contribution of topics related to international politics explained in a proportion of $19.8 \%$ an increase in references to Poland as a full member of the EU and, in the coverage of the economic issues, explained in a rate of $15.9 \%$ the references to Poland (as President of the EU and, simultaneously, a full member of the Union).

Regarding the sixth research hypothesis ("There is a higher probability that the topics covered in the articles published by the Romanian media, referring to Poland's foreign policy activity, issues related to the economy, domestic politics, culture or sport, be covered to a lesser extent in the period under review"), that was affected by the initial data analysis. Only $38 \%$ of the total of the Romanian newspapers which covered the Polish EU Presidency had the international politics as dominant theme, while only $28 \%$ of the sample articles published in the Romanian online media have covered the topic of international political relations of Poland as President of the Union. Going beyond the purely descriptive level, the inferential analysis further revealed, this time, some similarities and especially differences between the Polish Presidency of the EU coverage in the Romanian newspapers and online media. There was a $12 \%$ probability that the news published in newspapers on the Polish EU Presidency refer to international life and this probability was close in value $(12 \%)$ for the news published on-line on the same theme. Quoting an international news agency explains an increase of $23 \%$ in the number of newspapers articles on international life, while using international news agencies as a source explained $16 \%$ of the increase in the number of articles online on the same topic. Simultaneously, there was a $13 \%$ probability that an article making explicit reference to the impact on the economic life and on the country explain variation in Romanian newspaper coverage of Polish Presidency, the explanatory value of the same type of material being relatively close for online media $(11 \%)$. 
The most significant differences between logistic regression models were those that included variables related to the role and place of journalists in the newsroom. Thus, in the case of newspapers, the probability that the Polish Presidency coverage in newspapers with topics related to international politics would have increased by only $9 \%$ if the journalist had been a member of the editorial board. In contrast to this situation, if the journalist had been a member of the editorial online media board, there was a $16 \%$ probability that the Polish Presidency be covered in news on international politics. The relationship between covering economic topics and the journalist's status also varied significantly between newspapers and online media. Specifically, for the newspapers, the fact that a journalist who is a member of the editorial board issued an opinion article explained $8 \%$ of the increase in coverage of economic issues. If an online media journalist belongs to the editorial board, that explain $10.7 \%$ of the coverage increase of this topic through published articles.

\section{Conclusions}

According to the literature, the paradigm of journalism can be seen as a model that governs the collection of information, manifested in practical journalism and focused on the evaluation criteria of journalistic potential and on the ways of their transmission to the public. The cornerstone of this model is objectivity (Reese, 1997:424). The role of the media in this process is to make visible the limits of each definition of reality (Gitlin, 1980:253-254; Reese, 1997), the media reproducing a consistent ideology. As bearers of truth, journalists naturally oppose manipulation by sources or by their managers, which is quite likely to happen within the framework of their professional, having sufficient means available to achieve this thing. Accepting as a rule that the journalism is free form values, the media supports and emphasizes values, ideological frameworks and rules set by the dominant elites. The process of drafting news serves well to hegemonic principles as generally editing decisions are made by the editors, who are supposed to be more experienced and have a broader view of the world; they also have extensive contacts with officials and elite sources, which influences them in the formation of the "vision" of the world (Reese, 1997:420-437). In terms of specific theories of sociology of journalism (Shoemaker \& Reese, 1996), this study showed, therefore, to identify professional and organizational variables that explain the magnitude of Romanian media coverage in a specific process - more specifically, how the media in Romania presented the Polish EU Presidency.

The analysis of empirical data validated the third and fifth case study hypothesis. In this way, at the level of the entire sample of articles analyzed, covering the Polish EU Presidency in Romanian newspapers and online media was achieved mainly by providing routine events and, simultaneously, a frequent reference to the quality of the country's full membership in the European Union. The invalidation of the majority of the research hypotheses initially proposed led us to try to identify 
professional and organizational explanatory factors for coverage in Romanian newspapers and online media of the EU presidency. The explanatory models developed thus showed greater robustness of data on the sample of newspaper articles published in comparison to materials published online.

However, the same logistic regression models showed different influences realized by professional and organizational variables in the specific case of Romanian newspaper journalism and online media. To cover the specific subject of the Polish EU presidency in Romanian newspapers, it mattered that the author was a member of the editorial board (and not an external collaborator) and that he/she was quoting national and international news agencies when wrote a story about international politics or economics. Written news was published on the front page of the newspaper accompanied by a photo and, along with reference to the Polish Presidency of the EU, it included an explicit reference to the impact that the event or international political or economic process has on Romania. Schematically, these factors can be represented as in the diagram below.

Organizational culture

and professional routines

Sources

Event criteria

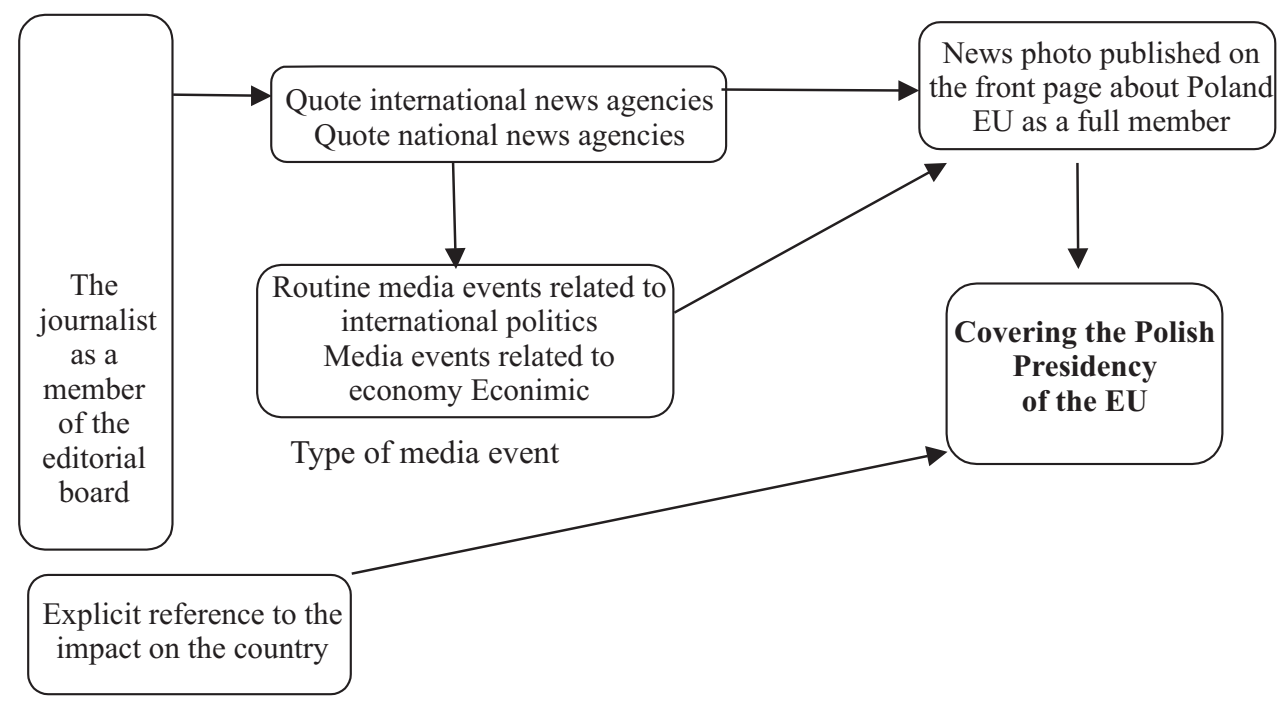

Ideological dimension

Figure 1. The possible model of the influences of professional and organizational variables on newspaper coverage of the Polish EU Presidency

In the specific case of Romanian online media coverage of the Polish EU Presidency, it mattered that the author was a member of the editorial board (and not an external collaborator) and that he/she was only quoting national news agencies when written a story or an article about economics or sport. Press material included 
an explicit reference to the impact of economic or sporting event or process has on the people of Romania. Schematically, these factors can be represented as in the diagram below. In our opinion, the results may contribute to understanding how media covers European transnational processes, for example the Polish Presidency of the EU in 2011-2012.

Organizational culture and professional routines

Sources

Event criteria

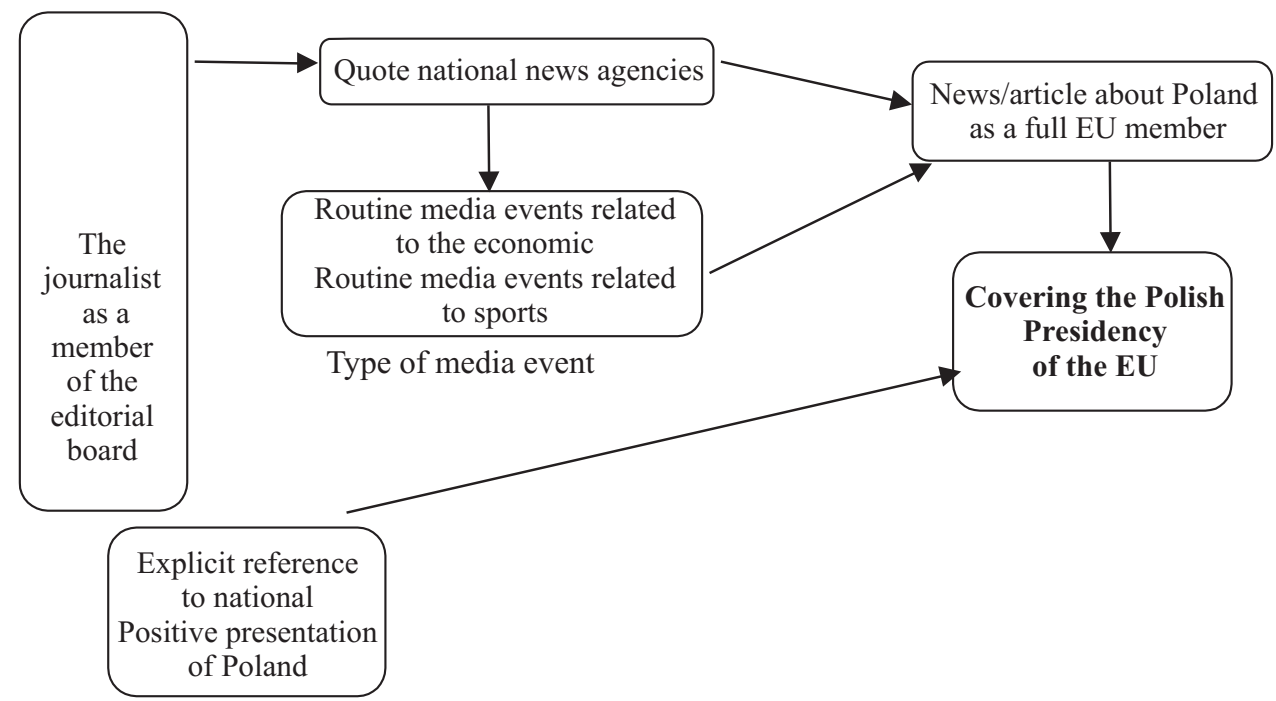

Ideological dimension

Figure 2. The possible model of the influences of professional and organizational variables on online media coverage of the Polish EU Presidency

Limitations of this study are of interest for future research. The analysis focused on a sample of articles published in the Romanian media (newspapers and on-line), the results can not be generalized to the level of a larger geographic and cultural area. Further research could test whether the results and empirical-theoretical models proposed can be found for a larger sample and/or if a sample should be included in the articles and news published in several European countries.

\section{References}

Bantz, Ch. (1997), "News Organization, Conflict as a Crafted Cultural Norm, The News Factory", in: D. Berkowitz (ed.), Social Meaning of News, Sage Publications Inc., 123-135.

Berkowitz, D. (ed.) (1997), Social Meaning of News, Sage Publications Inc.

Fishman, M. (1980), Manufacturing the news, Austin: University of Texas Press, 141-152. 
Golding, P. (1974), The Mass-Media, London: Longman.

Jeffres, L. (1986), Mass-media, processes and effects, Illinois: Waveland Press Inc., 106-108.

Mathien, M. (1992), Les journalistes et le système médiatique, Paris: Hachette.

McCombs, M. (2004), Setting the agenda, Cambridge: Polity Press.

Molotoch, H., Lester, M. (1997), “News as Purposive Behaviour, On the Strategic Use of Routine Events, Accidents and Scandals", in: D. Berkowitz (ed.), Social Meaning of News, Sage Publications Inc., 200-205.

Mouillaud, M., Tetu, J. F. (1989), Le journal quotidien, Presse Universitaire de Lyon.

Reese, S. (1997), "The News Paradigm and the Ideology of Objectivity", in: D. Berkowitz (ed.), Social Meaning of News, Sage Publications Inc., 420-437.

Rieffel, R. (1994), L'elite des journalistes, Paris: PUF.

Schudson, M. (1978), Discovering the news, New York: Basic Books Publ.

Schudson, M. (1997), “The Sociology of News Production”, in: D. Berkowitz (ed.), Social Meaning of News, Sage Publications Inc., 7-23.

Schudson, M. (2003), The Sociology of News, New York-London: W.W. Norton\&Company.

Shoemaker, P. J., Reese, S. D. (1996), Mediating the message-Theories of Influences on Mass Media Content, Longman Publishers ( $2^{\text {nd }}$ edition).

Shoemaker, P. J., (1997), “A New Gatekeeping Model”, in: D. Berkowitz (ed.), Social Meaning of News, Sage Publications Inc., 57-62.

Sorlin, P. (2002), Mass-media, Iaşi, Institutul European.

Stuart, A. (1999), News Culture, Buckingham: Open University Press.

Tuchman, G. (1997), "Making News by Doing Work, Routinizing the Unexpected", in: D. Berkowitz (ed.), Social Meaning of News, Sage Publications Inc., 173-189.

Van Cuilenburg, J. J., Scholten, O., Noomen, G. W. (1998), Ştiința Comunicării, Bucureşti: Humanitas.

White, M. D. (1997), “The Gate Keeper”, in: D. Berkowitz (ed.), Social Meaning of News, Sage Publications Inc., 63-79.

\section{Online sources:}

www.brat.ro. 
Agnieszka Stępińska, Bartłomiej Secler

Adam Mickiewicz University in Poznań

\section{Polish Printed Media Coverage and Evaluation of the Polish Presidency in the EU Council Presidency}

\section{Introduction}

Poland held its first presidency of the European Union Council in the second half of 2011. This was the fourth presidency held by a new EU member, after Slovenia, the Czech Republic, and Hungary. Alongside its political significance, the presidency offered an opportunity to show Poland in the best light, to present the image of a reliable, competent and trustworthy political partner (Fiałkowska, 2011:2; Stępińska, 2009; Kolczyński, 2013). Experts are generally convinced that a successful presidency depends on a state's thorough preparation for holding this function and the efficient implementation of the priorities the state has identified. In the context of the Polish presidency, the researchers additionally emphasized that its shape and character should directly refer to Poland's strategic presence in the EU (Albrycht \& Węć, 2011; Barcz, 2011; Czachór \& Tomaszyk, 2010; Fuksiewicz \& Szczepanik, 2010; Gromadzki, 2010; Grosse, 2007; Łada, 2011; Riedel, 2010). This calls for an exceptionally active attitude of a member state, whether in political activities or in generating new initiatives that are significant for the entire Union (Grosse, 2011:3-4). Political interests of the state must not be neglected, either. Balancing universal interests (i.e. the interest of the entire EU) with the individual interests of a member state holding the presidency is a considerable challenge. The reconciliation of these interests is conducive to succeeding in terms of both international and domestic politics and image.

Furthermore, a successful presidency of the European Union Council is to a large extent related to the image of the presidency generated by both, domestic and foreign media. The Czechs learned a bitter lesson in this respect in the first half of 2009 (Kaczyński, 2009; Kral, Bartovic \& Rihackova, 2009). The critical remarks on the Czech presidency voiced by other EU member states were frequently reported in the media. A number of articles, opinions and discussions tended to focus on Czech lapses and failures, rather than on a review and assessment of the priorities assumed by the Czech presidency. It should be remarked, however, that the Czech presidency was exercised under relatively difficult external conditions, related to the global economic crisis and internal problems stemming from the Euroskepticism of Czech President Vaclav Klaus and a government crisis, that brought about the collapse of Mirek Topolanek's government in the very middle of the Czech presidency (Secler, 2009:95). 
The concerns about the Polish presidency were related to the parliamentary elections, due to be held in Poland in 2011, during the Polish presidency. Poland was warned not to follow the Czech scenario of potential problems with the appointment of a new government, or the Danish scenario, where the government collapsed during the presidency. Since the paralamentary election campaign reached the final stage soon after Poland took a lead in the EU Council, political and journalistic comments emphasized that Donald Tusk's government would take advantage of the presidency during the competition with its political rivals. At the same time, political opposition could use any mistakes and problems related to the presidency as the arguments against the government. Despite of these concerns, parliamentary elections were quickly called and the new authorities elected (in fact, Poles elected the same administration for a second term) successfully presided over the EU.

Previous papers in this part of the volume included findings of the quantitative and qualitative content analysis of the selected printed and online media outside Poland. Two final papers will be devoted to the content of the Polish media. This paper aims in presenting the findings of the quantitative analysis of the content of selected Polish print media regarding the assessment of the Polish presidency; the following one is focused on a discourse analysis. Both of them attempt to provide a better understanding of relations between media organizations and political actors during the term of the first Polish EU presidency.

\section{Theoretical background and literature review}

Media coverage of the EU Council presidency can be studied within either an international or domestic context. By comparing data collected in the country holding the position with data from other countries one may recognize some universal patterns of reporting, as well as differences in levels of attention and frames used by journalists and commentators.

In the international context studies on the media coverage of the EU-related events and topics usually focus on providing information about a country to a foreign (or international) audience. Most of the scholarship attempts to provide answers to two main questions: to what extent media may shape attitudes and opinions concerning foreign countries (media effects), and which countries and events are actually covered by the foreign media (news value).

Since most people do not have personal knowledge of foreign events, the agenda setting effect of foreign news will loom stronger than that of domestic counterparts (Semetko, Brzinski, Weaver \& Willnat 1992; Hargrove \& Stempel, 2002; Wanta, Golan \& Lee, 2004). Therefore, the question of criteria used by the media to select either a country or a foreign event has been a subject of research for a long time, from classic works of Kayser (1953), Galtung and Ruge (1965), Gerbner and Marvanyi (1977), or Sreberny - Mohammadi (1984) to more recent works of Chang \& Lee (1992), Wu $(1998,2000)$, or Cohen et al. (2013). The main conclusion drawn from these studies is 
that the amount of news coverage depends on the proximity (or distance) between the countries and on their ethnographic, political, or economic relations. Hence, one may expect that European countries will be covered prominently in Europe, while the actual amount of news coverage will depend on the attributes and roles played by the country within the region.

On the other hand, since newsworthy events may focus media attention on the country, organizing or hosting such an event is one of the strategies of the media management (Signitzer \& Coombs, 1992; Rivenburgh, 2010). However, as Manheim (1994) suggests, for the countries with a very low or a very high level of visibility and negative image valance, hosting an international media event may not be the best option. But, the cumulative events, such as the EU presidency, provide an opportunity for a gradual image enhancement. During the six-month period of the presidency the government attempts to attract foreign media attention, not only as a host of numerous meetings and events, but also as an actor-in charge to at least call for some actions and solutions to the problems the EU is facing at that time. In fact, all the government's behaviours: decisions, actions, initiatives, or events may be perceived as particular signals sent to an international public opinion in order to influence the state's image (Stępińska, 2009).

In a domestic context, studying the media coverage of the EU presidency may provide an opportunity not only to learn which events were reported by journalists for domestic audience, but also to recognize political actors' and media attitude towards the EU institutions. In many European countries, including Poland, the pro-, or anti-EU attitude is a significant component of the political parties' identities and an element of diversification strategy used by political actors especially during the election campaigns (Stępińska, 2004; 2005). Furthermore, Polish media system shares with other Eastern Central European countries a high level of political parallelism and an external pluralism. Consequently, media organizations mirror the political situation of the country and journalism tend to be strongly marked by political partisanship (Hallin \& Mancini, 2004). This tendency is even more intense during any election campaign when the media plays a role of forum of a political debate.

Indeed, in Poland journalism may be described as politically-driven, opinionated, and advocay - oriented. R. Herbut (2002:110) suggests that in this part of Europe one may recognize political parties' strategic orientation towards 'colonization of public administration by rulling parties' that leads to politization of the media. In such a system "media suffers from a lack of impartiality, objectivity and fairness" (Wyka, 2008:64). There is no balance in editorial viewpoint and one of the main functions of the media is political mobilization.

Since the Central European press market has been mostly completely priviatized the main control of the rulling parties is concentrated on the public radio and television (Dobek-Ostrowska \& Głowacki, 2008:13). However, even on the press market, one may find a significant number of politically-oriented newspapers. Journalists working for some of these newspapers are deeply involved in politics (as comentators and publicists presenting their own opinions). K. Jakubowicz (1999:24) described this style of journalism as combining "a didactic journalistic 
norm, leadership and guardianship/stewardship roles vis-á-vis the audience, a special form of the social responsibility paradigm, a critical/dialectic role in society, assigning to the audience mostly the roles of pupils, citizens, partisans and followers" (in: Wyka, 2009:58).

\section{A study}

The study concentrates on the relation between political bias of selected Polish daily newspapers and weekly magazines and their evaluation of Poland's presidency in the European Union Council. ${ }^{1}$ Due to the explorative nature of the study, a quantitative content analysis addressed following research questions:

RQ1: How did the Polish media portray and evaluate the Polish EU presidency?

The articles published by the press were examined in terms of the assessments of the Polish presidency formulated by their authors or by the contributors to the selected daily newspapers and weekly magazines. Four categories of evaluation were identified in the codebook in order to examine whether the assessments and opinions are free from bias or irony towards the Polish government and other entities or individuals actively involved in the Polish presidency. Namely, these were following categories: (1) positive; (2) negative; (3) both positive and negative; or (4) neutral.

RQ2: To what extent did a political orientation of a media organization affect the coverage and evaluation of the Polish EU presidency?

Since all the major events related to the Presidency were organized by the government of Platforma Obywatelska [Civic Platform] and Polskie Stronnictwo Ludowe [Polish People's Party] and its agents, we may assume that journalists from the anti-governmental media organizations could criticize the political parties in power by providing negative evaluation of their performance during the EU Presidency period. Thus, we propose a hypothesis (H1) that the coverage will be biased and affected by the political angle of the news organization.

The data come from the research project devoted to study the role of media events in creating a state's image. ${ }^{2}$ The key word used to select the items for a study was presidency (of the EU Council). The timeframe encompassed 18 weeks, namely periods of June 15-July 30, 2011; September 1-October 31, 2011; and December 1, 2011-January 15, 2012. The analysis concerned four daily newspapers and three weekly magazines with following characteristics:

\footnotetext{
1 Additional issues for analysis identified in the code book included: journalistic genres, presentation of material, information sources, authors of opinions, topics, and roles (labels). More about the study in Stępińska (2012, 2013a, 2013b)

2 Research project: Prezydencja polska w Radzie Unii Europejskiej i Euro 2012: rola wydarzeń medialnych w ksztattowaniu wizerunku państwa [The Polish EU Presidency and Euro2012: the role of media events in creating a state's image] sponsored by the Polish National Science Center, grant no. N N116 614440.
} 
a) Gazeta Wyborcza - a nationwide socio-political news daily, owned by the Agora S.A. media concern. Gazeta Wyborcza is among the leaders of daily press in Poland. Since its origin, Adam Michnik has been its editor-in-chief. According to the 2011 data, average circulation amounts to 433,000 issues with sales at a level of 286,000 issues.

b) Rzeczpospolita - a nationwide news daily of a socio-political, economic and legal profile. It defines itself as "the only conservative-liberal journal in Poland." The daily has enjoyed a strong market position for many years. It is among the leaders of dailies in Poland, although it has recently noted a sales drop. Average circulation exceeds 146,000 issues with sales oscillating around 85,000 issues sold on average (statistics from the first half of 2012). In 2011 average circulation amounted to 188,000 with average sales at 106,000 issues.

c) Nasz Dziennik - a nationwide Catholic-nationalistic daily published by the Spes sp. z o.o. - a limited liability company. The daily was initiated in January 1998 by Rev. Tadeusz Rydzyk, the founder of the ultra-Catholic Radio Maryja. The newspaper's circulation is not monitored by the Association for Control of Press Distribution (ZKDP) which accounts for the lack of precise statistics as to sales. The information provided by the editor, however, indicates that average circulation is at a level of 150,000 issues with sales of 100,000 issues.

d) Fakt - a nationwide daily tabloid, published since 2003 by Axel Springer Polska, a part of the Axel Springer AG media concern. Fakt is the leader among the daily press in Poland. Statistics from March 2011 indicate that average circulation exceeded 544,000 issues with average sales of 499,000.

e) Polityka - a nationwide socio-political opinion-forming weekly with a long tradition: it has been present on the Polish market since 1957. The weekly is published by the Polityka sp. z o.o. - a limited liability company (formerly - by the Polityka Spółdzielnia Pracy cooperative). Polityka is among the leaders of opinion-forming weeklies in Poland. Average sales oscillate around a level of 130,000 issues. In 2011, average circulation was at a level of 188,000 issues with sales at a level of 133,000 .

f) Wprost - a nationwide socio-political opinion-forming weekly published in Warsaw by Platforma Mediowa Point Group. According to the Institute of Media Monitoring, in 2012 Wprost had the highest citation index among other weeklies, and one of the highest citation indices among the media in general in Poland. Average circulation in 2011 amounted to 182,000 issues with sales at a level of 112,000 .

g) Uważam Rze. Inaczej pisane - a nationwide politico-economic opinion-forming weekly published by Presspublica since 2011. The weekly is written in cooperation with the Rzeczpospolita daily. In June 2011 it came to the lead among opinion-forming weeklies (being second only to the Catholic Gość Niedzielny). Average circulation at that time was 329,000 issues with sales of 140,000.

The following pages constitute the core of the paper as they present findings of the study. First a content of the daily newspapers is analyzed, followed by a content of the weekly magazines. The next part attempts to compare the assessment of the 
Polish presidency in the selected dailies and weeklies. The paper is concluded by a summary of the issues outlined in the topic of the paper.

\section{Findings}

\section{The daily newspapers}

Taking into consideration the political bias of selected newspapers one could expect significant differences in their assesments of whether a given event or initiative should be deemed to be a success or failure of the Polish presidency. The dailies, however, did not demonstrate a strong emotional attitude to the cabinet that held the presidency, thus exhibiting defined political sympathies. It was a neutral assessment that prevailed in Gazeta Wyborcza (67\%) and a tabloid Fakt (57\%). The proportion of neutral assessments was lower by over a dozen in Rzeczpospolita (48\%), while in Nasz Dziennik they accounted for $46 \%$ of printed material (see Graph 1).

\section{Graph 1. The daily newspapers - neutral assessments}

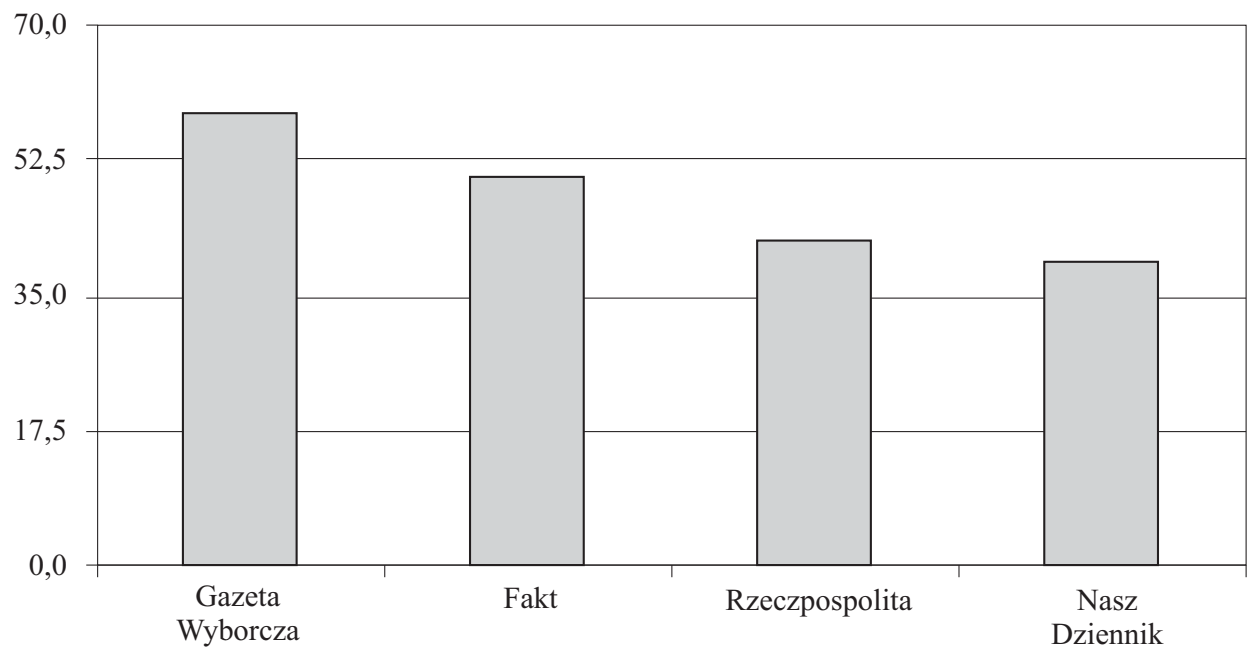

Not surprisingly, in a conservative and anti-governmntal daily newspaper Nasz Dziennik one third of opinions on the Polish presidency was negative (see Table 1). Speaking of the Polish presidency, the newspaper primarily criticized Prime Minister Donald Tusk and Minister of Foreign Affairs, Radosław Sikorski, accusing them of incompetence in ruling, submissiveness towards the heads and leaders of European Union states, lack of defense of Polish national interests. The titles of numerous items were indicative of the clearly negative tone of assessments and opinions, for instance: Sikorski a sprawa polska [Sikorski versus the Polish cause], Polska suwerenność oddam tanio [Polish sovereignty for sale - cheap], Jak najdalej od polskości 
[As far from Polishness as possible], Polityczny makijaż Platformy [PO's political make-up], Dawniej Moskwa, dziś Bruksela [Moscow yesterday, Brussels today], Z pamiętnika Donalda cudotwórcy [From the diary of Donald the miracle-worker].

The highest percentage of negative opinions could be found, however, in Fakt $(36 \%)$, while positive assessments of the Polish presidency accounted in this newspaper for fewer than $7 \%$ of all items. Fakt, although being a tabloid seems to be involved in a political debate by inviting politicians to share their comments and opinions (Piontek \& Hordecki, 2009). At the same time, most of the items on politics is strongly critical (not only of the government, but the entire political clas) and biased. In fact, many of the articles include some elements of populism and demagogy.

On the other hand, the highest proportion of positive assessments was recorded for Rzeczpospolita (34\%). Nevertheless, this newspaper published also a relatively high proportion (13\%) of critical (negative) assessments and opinions of Polish presidency. The other high quality dail newspaper - Gazeta Wyborcza published a smaller number of positive assessments than Rzeczpospolita, namely $23 \%$, and a very small number of negative assessments (3\%). Although Gazeta Wyborcza was more enthusiastic about the presidency, on numerous occasions treating it as an opportunity for Poland in Europe, in terms of politics as well as image, it seems to stay more neutral while reporting the event.

The codebook included also a category of both positive and negative evaluation in order to recognize items combining critique with some elements of approval for Poland's performance during the EU presidency. This attitude might be perceived as an attempt to present a balanced, but not neutral, picture. Interestingly, this type of comment was rather rarely used by authors of opinions publishing in daily newspapers. The highest percentage of such items were found in Nasz Dziennik (12\%), while Gazeta Wyborcza and Rzeczpospolita published only 7\% and 6\% of this kind of items, respectively. It is worth mentiong that Fakt featured the most clear assessments in that matter, as the category of both positive and negative never occurred. It seems that journalists rather attempted to avoid any comments or represented a clear (positive or negative) attitude towards activities of the Polish government and any other institution involved into activities related to the EU Council presidency (see Table 1).

Table 1

The daily newspapers - the assessment of the Polish presidency (\%)

\begin{tabular}{||l|c|c|c|c||}
\hline \multicolumn{1}{|c|}{ ASSESSMENT } & $\begin{array}{c}\text { Gazeta Wyborcza } \\
(\mathbf{n = 2 0 9 )}\end{array}$ & $\begin{array}{c}\text { Rzeczpospolita } \\
(\mathbf{n = 2 4 6})\end{array}$ & $\begin{array}{c}\text { Fakt } \\
(\mathbf{n}=\mathbf{6 1})\end{array}$ & $\begin{array}{c}\text { Nasz Dziennik } \\
(\mathbf{n}=\mathbf{9 6})\end{array}$ \\
\hline Positive & 23 & 33 & 7 & 9 \\
\hline Negative & 3 & 13 & 36 & 33 \\
\hline Both positive and negative & 7 & 6 & 0 & 12 \\
\hline Neutral & 67 & 48 & 57 & 46 \\
\hline TOTAL & 100 & 100 & 100 & 100 \\
\hline
\end{tabular}




\section{The quality weekly magazines}

M. Nieć (2010:14-16) defines quality magazines as publications presenting the standpoints and opinions of individuals, groups, political parties and other social groups that influence public opinion and shape attitudes and beliefs. Quality magazines are addressed at people who are interested in various aspects of socio-political and economic affairs. Such magazines differ from newspapers and tabloids as they publish longer and more extensive items that are conducive to in-depth considerations. Depending on the features of the media systems, weekly magazine may either represent one political angle or attempt to draw a broader picture of the events and issues by providing more than one perspective. In media systems with a high level of political parallelism one may expect rather the former option, than a latter.

Positive assessments of the Polish presidency prevailed in two out of the three magazines under the study. They accounted for $46 \%$ of all assessments in Wprost, and for $34 \%$ in Polityka. The third magazine examined, Uważam Rze, diverged significantly from the above two in terms of the positive assessment of the presidency. Its positive assessment amounted to only $5 \%$ of all opinions. Negative opinions prevailed in this magazine. The results of the studies indicate that there were as many as $54 \%$ of them (see Graph 2 and Table 2). Therefore, it can be surmised that the majority of both the journalists and contributors to this weekly could be associated with the right side of the political stage and critics of Donald Tusk's administration. The pessimistic attitude of the magazine towards the Polish EU presidency could already be sensed several weeks prior to its official beginning. Marek Magierowski in his article Ratuj się, kto może [Run for your life] observed that the Polish presidency would fall in a period of political stagnation in Europe (Magierowski, 2011).

Graph 2. Quality weekly magazines - positive and negative assessments

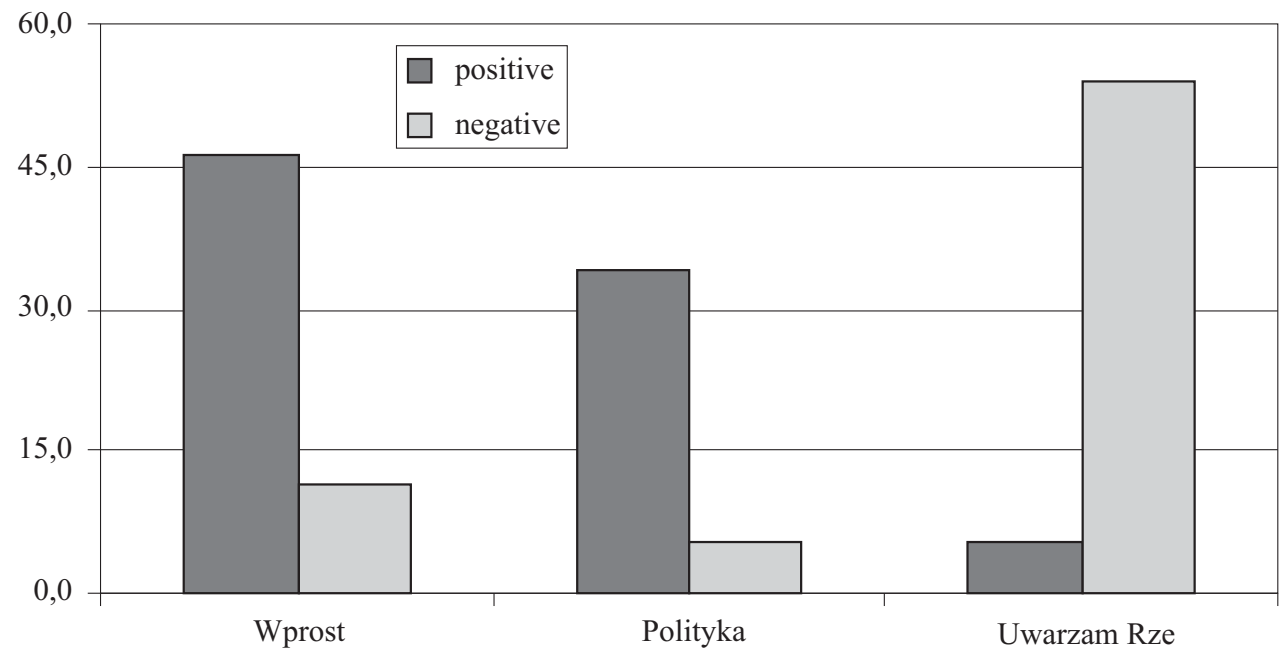


The number of negative opinions published in Polityka was the same as that of positive ones in Uważam Rze. The sample examined evidenced that the negative opinions on the Polish presidency published in Wprost accounted for slightly over $11 \%$ of all the examined texts in this magazine. The number of both positive and negative assessments was comparable in all the opinion-forming magazines analyzed, oscillating around 5-7\%.

As far as neutral assessments are concerned, it should be emphasized that Polityka published the largest proportion of them, accounting for $52 \%$, in comparison to $35 \%$ of neutral assessments identified by the study in the samples examined in Wprost and Uważam Rze. Although the number of neutral opinions is comparable, the three magazines show significant differences in other categories of the sample examined. Positive assessments prevailed in Wprost, while negative comments accounted for only a few percent there. The proportion was opposite in Uważam Rze.

Table 2

The weekly magazines - the assessment of the Polish presidency (\%)

\begin{tabular}{|l|c|c|c|}
\hline \multicolumn{1}{|c|}{ ASSESSMENT } & $\begin{array}{c}\text { Wprost } \\
(\mathbf{n = 2 6 )}\end{array}$ & $\begin{array}{c}\text { Polityka } \\
(\mathbf{n = 3 8 )}\end{array}$ & $\begin{array}{c}\text { Uważam rze } \\
\text { (n=37) }\end{array}$ \\
\hline Positive & 46 & 34 & 5 \\
\hline Negative & 11 & 5 & 54 \\
\hline Both positive and negative & 8 & 8 & 6 \\
\hline Neutral & 35 & 53 & 35 \\
\hline TOTAL & 100 & 100 & 100 \\
\hline
\end{tabular}

\section{Daily newspapers and weekly magazines: a comparison}

It is worth mentioning that positive opinions on the presidency were more frequent - in total - in the weeklies (29\%) than in the dailies (18\%). At the same time, the disproportion between the dailies and weeklies was insignificant as far as negative opinions are concerned (21\% and $24 \%$ respectively). However, one should consider the differences in frequency of publishing each medium and a total number of items published in the period of the study (altogether 612 items publihed in daily newspapers and 101 in weekly magazines).

Neutral opinions prevailed in daily newspapers counted together: in as many as $54 \%$ items journalists or other commentators avoided any evaluation of the Polish EU presidency. Weekly magazines altogether published $41 \%$ of such articles. However, differences between media organizactions were quite considerable, ranging from $35 \%$ in the weekly magazine Wprost to $67 \%$ in the daily high quality newspaper Gazeta Wyborcza (see Graph 3 and Graph 4). 
Graph 3. The dailies and weeklies - positive and negative opinions

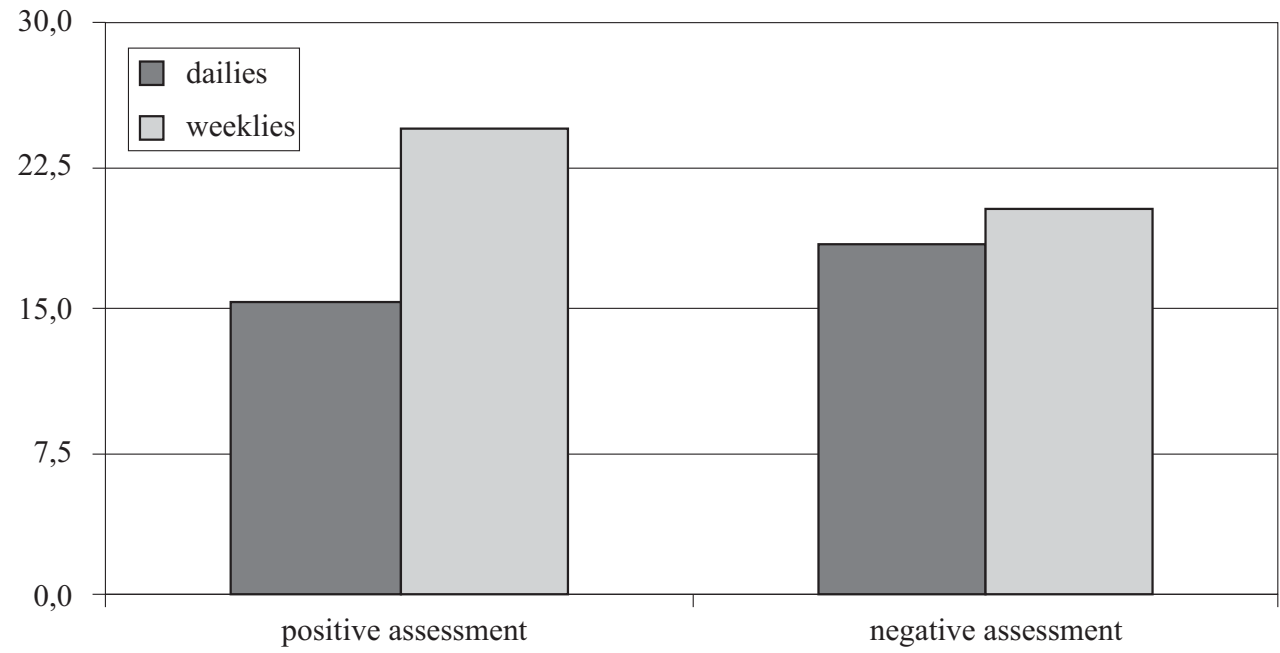

Graph 4. The daily newspapers and weekly magazines - neutral attitude

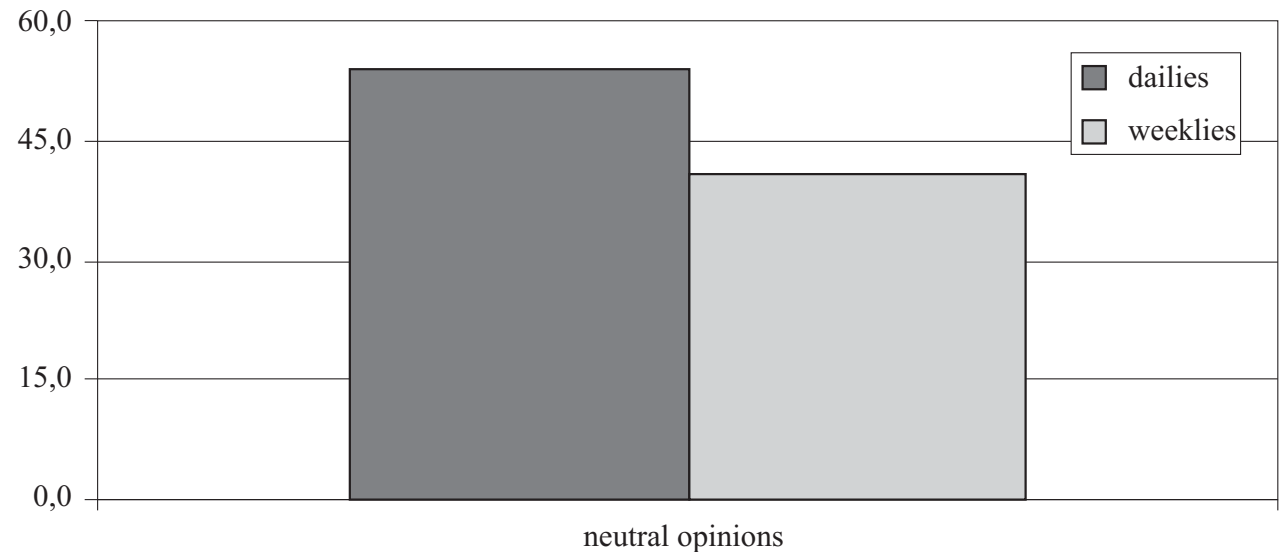

In particular, the study revealed significant differences between content of daily newspaper Rzeczpospolita and weekly magazine Uważam Rze - two titles sharing the same publisher. Although both media organizations used to belong to the same owner and hired the same group of publicists at that time, positive opinions in Rzeczpospolita accounted for as many as 33\%, while there were only $5 \%$ of them in Uważam Rze. A similar disproportion is reflected in case of negative opinions with $13 \%$ in Rzeczpospolita and 54\% in Uważam Rze (see Graph 5). It is worth mentioning that in a 18-week period Rzeczpospolita published 246 items expressing any evaluation or opinion, while Uważam rze 37 items. It means that only 2 out of 37 items in Uważam rze included some elements of approval for Poland's (or, in fact, Polish government's) performance. At the same time as many as 20 items were profoundly critical. 
Interestingly, in both of these media organizations almost the same group of journalists and commentators covered and commented on the Polish presidency in the first months of the term. It seems that journalists perceived their role differently depending on a type of media outlet they were publishing in at that time. While in Rzeczpospolita they were focused on providing more complex picture of government's activities, in Uważam rze they expressed their criticism openly. In late 2011, when more radical right-wing journalists and commentator left Rzeczpospolita and started working exclusively for Uważam rze. Not surprisingly, their comments became even more directly targeted against the government and its performance.

\section{Graph 5. Rzeczpospolita and Uważam Rze - positive and negative opinions}

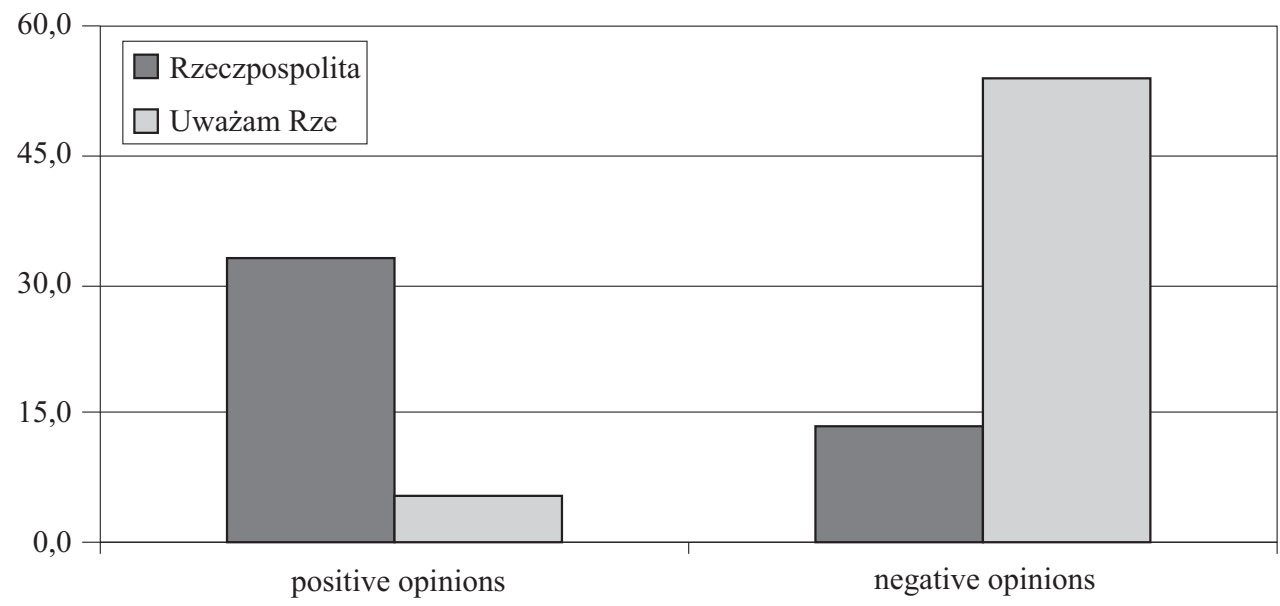

While studying items including opinions, comments and reviews, we decided to check who had an opportunity to present their points of view. Interestingly, as findings collected in Table 4 show, journalists and reporters were authors of almost half of the opinion items published in Gazeta Wyborcza (44\%) and Rzeczpospolita (43\%). In all weekly magazines the numbers were even higher: $83 \%$ in Polityka, $67 \%$ in Uważam rze, and 52\% in Wprost. Media organizations invited external sources of opinion less frequently.

Although the topic required a deep knowledge on both domestic and foreign politics, as well as on international relations and the EU policy, experts' opinions were in some media presented even less frequently than politicians' opinions. For example, in Gazeta Wyborcza 31\% of the opinion items included comments expressed by either a national or foreign politician, while only half of this number $(16 \%)$ presented experts' opinions. Similar tendency one may observe in Rzeczpospolita, although in that case national experts were interviewed (or invited to write their own text) more frequently, namely in $21 \%$ of the items. Rzeczpospolita, Nasz Dziennik, Fakt and all weekly magazines hardly ever or never published items with a comment of any foreign expert. 
At the same time, national politicians were often invited by some of the media organizations to present their opinions. In Fakt one third of all authors of opinions were national politicians (and neither foreign politicians, nor foreign experts), in Nasz Dziennik and Gazeta Wyborcza more than 20\%, while Polityka and Wprost did not publish any text presenting exclusively opinions of any Polish politician. As expected, Nasz Dziennik published mostly right-wing politicians. The opinions of left-wing politicians, or those from the current administration, were not presented in this newspaper.

It is worth mentioning that foreign authors' (politicians' and experts') opinions were presented significantly less frequently than national ones. For example, in Nasz Dziennik, where $29 \%$ of the opinions were expressed by national experts, only $1 \%$ of the comments' authors were foreign experts. Even in high quality daily newspapers such as Gazeta Wyborcza and Rzeczpospolita foreign experts were authors of as few as $4 \%$ and $2 \%$ of the opinion items, respectively.

Author of opinion

\begin{tabular}{|c|c|c|}
\hline Media & Author of opinion & Frequency $(\%)$ \\
\hline 1 & 2 & 3 \\
\hline \multirow[t]{7}{*}{ Gazeta Wyborcza } & editorial staff & 6 \\
\hline & journalist, reporter & 44 \\
\hline & national politician & 20 \\
\hline & foreign politician & 11 \\
\hline & national expert & 13 \\
\hline & foreign expert & 4 \\
\hline & other & 2 \\
\hline \multirow[t]{8}{*}{ Rzeczpospolita } & editorial staff & 4 \\
\hline & journalist, reporter & 43 \\
\hline & national politician & 17 \\
\hline & foreign politician & 7 \\
\hline & national expert & 21 \\
\hline & foreign expert & 2 \\
\hline & citizen & 3 \\
\hline & other & 3 \\
\hline \multirow[t]{7}{*}{ Nasz Dziennik } & editorial staff & 3 \\
\hline & journalist, reporter & 31 \\
\hline & national politician & 24 \\
\hline & foreign politician & 1 \\
\hline & national expert & 29 \\
\hline & foreign expert & 1 \\
\hline & other & 11 \\
\hline
\end{tabular}




\begin{tabular}{||l|l|c||}
\hline \multicolumn{1}{|c|}{1} & \multicolumn{1}{|c|}{2} & 3 \\
\hline Fakt & journalist, reporter & 50 \\
\cline { 2 - 3 } & national politician & 30 \\
\cline { 2 - 3 } & national expert & 10 \\
\cline { 2 - 3 } & other & 20 \\
\hline \multirow{5}{*}{ Polityka } & editorial staff & 7 \\
\cline { 2 - 3 } & journalist, reporter & 83 \\
\cline { 2 - 3 } & national expert & 7 \\
\cline { 2 - 3 } & citizen & 3 \\
\hline \multirow{4}{*}{ Upważam rze } & journalist, reporter & 52 \\
\cline { 2 - 3 } & national expert & 43 \\
\cline { 2 - 3 } & other & 5 \\
\hline & editorial staff & 68 \\
\cline { 2 - 3 } & journalist, reporter & 3 \\
\cline { 2 - 3 } & national politician & 3 \\
\cline { 2 - 3 } & national expert & 3 \\
\cline { 2 - 3 } & foreign expert & \\
\cline { 2 - 3 } & other & \\
\hline
\end{tabular}

\section{Conclusions}

In this paper we proposed a hypothesis that media coverage would be politically biased and we would be able to recognize this bias while studying the way newspapers evaluated the Poland's performance during the presidency. The hypothesis was confirmed. Indeed, the newspapers with an anti-government orientation provided more negative evaluation of the presidency. Namely, in Uważam rze more than half of the items expressed negative evaluation and in Nasz Dziennik one third of all materials included some critique of the government and its performance. It is worth mentioning that also Fakt was highly critical, but in this case the tabloid profile of the newspaper may be a reason for focusing mostly on negative events or aspects of particular political issues.

At the same time two weekly magazines, Polityka and Wprost presented rather positive image of the Polish EU Presidency. In Wprost almost a half of all items including any evaluation provided a positive opinion, while in Polityka one third of the evaluations was positive. The most balanced picture of the Polish EU Presidency was drawn by Gazeta Wyborcza. Surprisingly, Rzeczpospolita, despite of its political orientation, provided rather balanced image of the Poland's performance. In 2011 both Rzeczpospolita and Uważam rze were owned by the same owner, but Uważam rze hired more radically right-wing, anti-government publicists.

That leads us to the conclusion that the political profiles of the media organizations were expressed not only by the content of opinions and evaluations, but also 
by categories of sources of these comments. As the findings of the study showed, most of the items including the opinions and evaluations were written by staff members. Furthermore, journalists seemed to be more interested in the opinions of national politicians, than either national or foreign experts. As a result, the framework of the coverage was predominantly domestic. Journalists working for daily newspapers focused mostly on providing news and their own interpretations of the reported events. On contrary, weekly magazines provided comments and interviews, but again, most of the opinions were expressed by journalists and editors, than experts. The following paper, written by Artur Lipiński, presents the consequences of such features of the Polish media organizations on a discourse style and aruments provided by journalists during first Polish EU presidency term.

\section{References}

Albrycht, I., Węć, J. (2011), Bilans prezydencji belgijskiej w Unii Europejskiej. Wnioski dla polskiej prezydencji [Summary of Belgian EU Presidency. Conclusions for Polish Presidency], Brief Programowy Instytutu Kościuszki.

Barcz, J. (2011), Prezydencja w Radzie Unii Europejskiej [EU Council Presidency], Centrum Informacji Europejskiej.

Chang, T. K., Lee, J. W. (1992), “Factors affecting gatekeepers' selection of foreign news: A national survey of newspaper editors", Journalism Quarterly, No. 3, 554-561.

Cohen, A. A. et al. (2013), Foreign News on Television. Where in the World is the Global Village?, Peter Lang.

Czachór, Z., Tomaszyk, M. (eds) (2010), Przewodnictwo państwa w Radzie Unii Europejskiej - doświadczenia partnerów, propozycje dla Polski [EU Council Presidency - Partners' Experience, Suggestions for Poland], Instytut Spraw Publicznych.

Dobek-Ostrowska, B., Głowacki, M. (2008), “Introduction: Central European Media between Politization and Commercialization", in: B. Dobek-Ostrowska, M. Głowacki (eds), Comparing Media Systems in Central Europe. Between Commercialization and Politicization, Wrocław: Wydawnictwo Uniwersytetu Wrocławskiego, 9-24.

Fiałkowska, K. (2011), Analizy i opinie [Analyses and opinions], Warszawa: Instytut Spraw Publicznych.

Fuksiewicz, A., Szczepanik, M. (2010), “Parlament Europejski jako partner polskiej prezydencji" [European Parliament as A Partner of Polish Presidency], Analizy i Opinie, No. 112, Instytut Spraw Publicznych.

Galtung, J., Ruge, M. (1965), “The structure of foreign news: The presentation of the Congo, Cuba and Cyprus crises in four Norwegian newspapers", Journal of Peace Research, No. 1, 64-91.

Gerbner, G., Marvanyi, G. (1977), “The many worlds of the world's press”, Journal of Communication, No. 1, 52-66.

Gromadzki, G. (2010), “Jaka Prezydencja? Uwagi po wejściu w życie traktatu lizbońskiego" [What Kind of Presidency? Comments on The Lisbon Treaty], Analizy i Opinie, No. 109, Instytut Spraw Publicznych. 
Grosse, T. G. (2011), Polska prezydencja w Unii Europejskiej [The Polish EU Presidency], Warszawa: Instytut Spraw Publicznych.

Hallin, D., Mancini, P. (2004), Comparing Media Systems. Three Models of Media and Politics, Cambridge: Cambridge University Press.

Hargrove, T., Stempel, G. H. (2002), “Exploring reader interest in international news”, Newspaper Research Journal, No. 23(4), 46-51.

Herbut, R. (2002), “Teoria i praktyka funkcjonowania partii politycznych” [Theory and practice of politucal parties], Wrocław: Wydawnictwo Uniwersytetu Wrocławskiego.

Jakubowicz, K. (1999), The Role of Broadcasters is to Serve the Public Not the State. Presentation during the Zagreb Conference on Reforming Broadcasting, in: A. W. Wyka, In Search of The East Central European Media Model - The Italianization Model? A Comparative Perspective on the East Central European and South European Media Systems, in: B. Dobek-Ostrowska, M. Głowacki (eds), Comparing Media Systems in Central Europe. Between Commercialization and Politicization, Wrocław: Wydawnictwo Uniwersytetu Wrocławskiego, 55-69.

Kolczyński, M. (ed.) (2013), Obraz prezydencji Polski w Radzie Unii Europejskiej (2011) w wybranych tytułach prasy polskiej [Image of Polish EU Presidency (2011) in selected Polish printed press], Katowice: GNOME - Wydawnictwa Naukowe i Artystyczne.

Král, D., Vladimír Bartovic, V., Rihácková, V. (2009), The 2009 Czech EU Presidency: Contested Leadership at a Time of Crisis, Swedish Institute for European Policy Studies.

Łada, A. (2011), The Polish Presidency - pushing the agenda and shaping the Lisbon system, Instytut Spraw Publicznych - Policy Brief.

Magierowski, M. (2011), Ratuj się, kto może [Rid yourself if you can], available at: http:/ / www.rp.pl/artykul/653268.html, accessed on September 28, 2013.

Manheim, J. B. (1994), Strategic Public Diplomacy and American Foreign Policy: The Evolution of Influence, New York.

Nieć, M. (2010), “Pisma opinii i czasopisma life style - dwie koncepcje rynkowego dziennikarstwa (analiza Polityki, Wprost, Elle, Playboya i Twojego Stylu)" [Opinion and Life style magazines - two concepts of market journalism. Analysis of Polityka, Wprost, Elle, Playboy and Twój Styl], Zeszyty Prasoznawcze 1-2, 201-202.

Piontek, D., Hordecki, B. (2009), "Ideał polityka w "Super Expressie" i "Fakcie. Gazecie Codziennej" (lipiec-sierpień 2007)" [Ideal politician according to "Super Express" and "Fakt" (July - August 2007)], in: J. Miluska (ed.), Polityka i politycy. Diagnozy, oceny, doświadczenia [Politics and politicians. Diagnoses, evaluations, experiences], Poznań, 391-412.

Riedel, R. (ed.) (2010), Polska prezydencja w Unii Europejskiej 2011 [Polish EU Presidency 2011], Opole: Uniwersytet Opolski.

Rivenburgh, N. K. (2010), “In pursuit of a global image: media events as political communication”, in: N. Couldry, A. Hepp, F. Krotz (eds), Media Events in a Global Age, London-New York, 187-202.

Secler, B. (2009), "Prezydencja czeska na łamach polskiej prasy" [Polish media coverage of the Czech presidency], in: Z. Czachór, M. J. Tomaszyk (eds). Przezodnictwo państwa $w$ Radzie Unii Europejskiej - doświadczenia partnerów, propozycje dla Polski [Presidency in the EU Council: parners' experience, suggestions for Poland], Poznań: Wydawnictwo Naukowe WNPiD UAM. 
Semetko, H. A., Brzinski, J. B., Weaver, D., Willnat, L. (1992), “TV news and U.S. public opinion about international countries: The impact of exposure and attention", International Journal of Public Opinion Research, No. 1, 18-36.

Signitzer, B. H., Coombs, T. (1992), “Public Relations and Public Diplomacy Conceptual Convergences", Public Relations Review, No. 2, 137-147.

Sreberny-Mohammadi, A. (1984), "The 'world of the news' study", Journal of Communication 34(1), 121-134.

Stępińska, A. (2004), “Problematyka europejska w przekazach programowych kandydatów na urząd Prezydenta RP w latach 1990-2000" [European issues in election agendas of the Polish presidential candidates in 1990-2000], in: S. Wojciechowski (ed.), Europejskie dylematy i wyzwania [European dilemmas and challenges], Poznań: Wydawnictwo WNPiD UAM, 107-124.

Stępińska, A. (2005), “Telewizyjna kampania referendalna jako arena rywalizacji politycznej. Referendum unijne w Polsce w 2003 r." [Referendum campaign on TV as a sphere of political competition], Środkowoeuropejskie Studia Polityczne, No. 1, 39-58.

Stępińska, A. (2009), “Wizerunek państwa - działania PR nie tylko w okresie prezydencji” [A state's image - public relations not only during the presidency term], in: Z. Czachór, M. J. Tomaszyk (eds), Przewodnictwo państwa w Radzie Unii Europejskiej - doświadczenia partnerów, propozycje dla Polski [Presidency in the EU Council: partners' experience, suggestions for Poland], Poznań, 159-170.

Stępińska, A. (2012), "Media Coverage of the Polish EU Presidency", Yearbook of Polish European Studies, No. 15, 61-81.

Stępińska, A. (2013a), "International project: Media coverage of the Polish EU presidency", Środkowoeuropejskie Studia Polityczne, No. 3, 71-86.

Stępińska, A. (2013b), “The Polish EU presidency in Polish press: Did we actually notice it?”, Środkowoeuropejskie Studia Polityczne, No. 3, 191-206.

Wanta, W., Golan, G., Lee, Ch. (2004), “Agenda setting and international news: media influence on public perceptions of foreign nations", Journalism \& Mass Communication Quarterly, No. 81, 364-377.

$\mathrm{Wu}, \mathrm{H}$. D. (1998), “Investigating the determinants of international news flow. A meta-analysis", Gazette, No. 6, 493-512.

Wu, H. D. (2000), "Systemic determinants of international news coverage: A comparison of 38 countries", Journal of Communication, No. 2, 110-130.

Wyka, A. W. (2008), "In Search of The East Central European Media Model - The Italianization Model? A Comparative Perspective on the East Central European and South European Media Systems", in: B. Dobek-Ostrowska, M. Głowacki (eds), Comparing Media Systems in Central Europe. Between Commercialization and Politicization, Wrocław: Wydawnictwo Uniwersytetu Wrocławskiego, 55-69. 
Artur Lipinski

Adam Mickiewicz University in Poznań

\section{Presidency as a Political Battleground. Media and the Polish Presidency of the European Union Council}

\section{Introduction}

The Presidency of the Council of the European Union is of particular importance to Poland and other new member states, for which it marks a significant shift from being a mere subject of others' decisions to the status of a crucial player in the EU institutional architecture. In this sense, the Polish Presidency may be perceived as a culmination of the integration process - a sort of 'rite of passage' followed by a full initiation into the twists and turns of EU politics (Nowak-Far, 2011:18). Interestingly, the coverage of the Presidency in the Polish media and their political role in this regard has so far been discussed relatively little. However, implementation of the many tasks of the Presidency, including the role as a broker of interests, is not possible without the mass media, being capable of strengthening, weakening or even undermining the actions of political actors (Lipiński, 2010). The importance of media representation is best evidenced by the fact that successful cooperation with the media is one of the measures of the effectiveness of the Presidency as a whole (Młynarski, 2011:201-248).

This paper aims to cover this shortfall through an analysis of the discursive means of constructing the Polish Presidency in three influential national weekly journals with different political positions and editorial lines: Polityka, Wprost and Uważam Rze. In the analysis they are treated as agents with observable behavior, unified enough to pursue coherent discursive strategies (Page, 1996:20), i.e. intentional plans of practices used to achieve social, political, psychological or linguistic purposes (Reisigl \& Wodak, 2001:44). This presentation of media as political actors is especially justified in Poland where strong political polarization is being enhanced by the media, and where political groups are supported not only by their constituent social organizations, but also by the openly partisan press. For example, Polityka and Wprost have a pro-government stance and strongly pro-European sympathies, while the softly eurosceptic Uważam Rze is a sharp critic of the policies of the Donald Tusk's government.

This article uses analytical tools from discursive-historical version of critical discourse analysis, especially the concept of discursive strategies proposed by Ruth Wodak and Martin Reisigl. A particularly useful heuristic tool in the study of political discourse is the analysis of the means of nominalization developed by M. Reisigl. These means include nomination (the construction of social actors), predication (at- 
tribution of specific, positive or negative traits), and argumentation (justification or delegitimization of claims containing specific nominations and predications) (Reisigl, 2008:99).

The analytical framework of a discursive-historical approach is used in the systematic study of texts to determine a picture of the Polish Presidency in selected media. This general goal is connected with two more specific research questions. First, what is the representation of Poland in the discourse about the Presidency? Second, what is the representation of Europe/European Union in the discourse about the Presidency? The results of the analysis shall reveal the diversity of images and evaluations of the Presidency and the main parameters of the "battleground" that the discourse on national identity and Europe has become in many European countries (Diez, 2001).

A comparison of alternative constructs of the same reality is the best way to reveal subtle ideological mechanisms that constitute the discourse (Carvalho, 2008:171). Accordingly, a detailed analysis of the mechanisms of representation of the Polish Presidency in the European Union shall reveal the means of naming and identifying the main actors in the discourse and the methods of quatation, evaluation and argumentation. In particular, the analysis of representations of Poland focuses on predictions and hopes regarding the Presidency, representation of the government, the opposition and their mutual relations, the role of the Polish Presidency, evaluation of the government and the opposition during the Presidency, and the overall assessment of the Presidency. Representations of Europe are examined based on the analysis of how the actors define the status quo ('what is the EU?', 'what is its current condition?'), the internal diversity of the EU and differences of interests between countries.

There are two general positions towards the Polish Presidency and two major representations of Poland and Europe/EU. These positions can be distinguished on the basis of frequently repeated, assumed or explicitly expressed views on the status of the Presidency in the press representations. The first position, dominant in the discourse of Polityka and Wprost, frames the Presidency as a task, while the second, typical for Uważam Rze, defines the Presidency as appearance. Both approaches are systematically employed in the corpus of analyzed texts and are used to construct arguments, rhetorical figures and metaphors. They are associated with a variety of topics, such as the role of Poland in Europe, Polish actions during the Presidency, the question of the future of Europe, the importance of the parliamentary elections during the Presidency, and the importance of the Presidency for those in power.

\section{The Presidency as a task}

\section{Social and political actors - quotation and representation}

The attitude towards the Polish Presidency of the EU Council is shown by the selection of authors and interviewees. In the case of Polityka, texts heralding the begin- 
ning of the Presidency and summarizing the periods were prepared by: Mark Ostrowski, the author of texts on international affairs, Jerzy Baczyński - editor-in-chief, Paweł Świeboda - the president of pro-European foundation demosEuropa European Strategy Centre and a regular columnist of Gazeta Wyborcza, and Adam Krzemiński - a journalist specializing in topics related to Germany. The authors of texts that appeared in Wprost were Magdalena Środa (a regular columnist) and Jacek Pawlicki - a journalist of Gazeta Wyborcza who specializes in the European issues.

Interestingly, in both journals, authors from the outside were presented as impartial experts on the European Union, even though they were directly associated with other magazines supporting the government of Donald Tusk. The dominant objective and expert style in the articles was also supported by the selection of interlocutors, usually government or the EU officials and experts. These included Janusz Lewandowski - commissioner for financial planning and the budget of the EU, Mikołaj Dowgielewicz - Secretary of State for European Affairs in charge of the Polish Presidency at the Ministry of Foreign Affairs, and Jacek Kucharczyk - President of the Institute of Public Affairs (Instytut Spraw Publicznych). Wprost also interviewed Paweł Świeboda, author of texts in Polityka.

Due to the characteristics of the journalism genres in the analyzed weekly magazines (current affairs article, editorial, interview), the number of quotations is much smaller than in the case of newspapers (Wojtak, 2004). Using direct and indirect speech, the articles quoted the Prime Minister Donald Tusk, spokesman for the Polish Presidency Konrad Niklewicz, the Minister of Foreign Affairs Radosław Sikorski, scientists, left-wing intellectuals, experts (such as Michael Porter from the Harvard Business School, Jürgen Habermas, Timothy Garton-Ash, Daniel Cohn-Bendit), as well as politicians, other countries, or the EU (such as Jean-Claude Junckner - Prime Minister of Luxembourg, and Martin Schulz - president of the Socialist Group in the European Parliament). Quotes from government politicians usually expressed the line of the journal or individual journalists, which sometimes assumed the form of openly expressed support for a particular position: "Meanwhile, Sikorski is right [...]" (Krzemiński, 2011b:12).

Discourse on the Presidency with reference to Poland and its internal situation most frequently used the metonymic term "Poland". The name of the country served to describe the actions taken by the government and its representatives, and often was meant to denote the entire nation (Kucharczyk, 2012:92). This procedure was used to build a community of identity and interest, and at the same time suspended the question of internal differentiation. While constructing the role of Poland an anthropomorphic representation of the country as an actor who should take or has taken concrete action was used. Poland "showed", "received" or even "does not like" (Kucharczyk, 2012:92; Środa, 2011:31).

Other frequently mentioned domestic actors included government politicians: Donald Tusk, Radosław Sikorski, The Finance Minister Jacek Rostowski, and a prominent figure of the Civic Platform political party - Stefan Niesiołowski. They 
were represented as perlocutively effectiveactors whose words are cited in an affirmative way. For example, D. Tusk was a "European modernizer" (Łakomski, 2011:28), while the "reasonable politician" R. Sikorski was the author of a very important speech which had been awaited since the beginning of the Presidency (Krzemiński, 2011b:12). The government officials were not criticized but rather encouraged to be more active. For example: "The Prime Minister must begin to be visible" (Ostrowski \& Świeboda, 2011:52). An important instrument was functionalization, a tool using the mention of positions in the representation of social actors (Van Leeuven, 2008:42): “The idea that the Finance Minister Jacek Rostowski, as representative of the Presidency, could sit at one table of the euro-group without the right to vote (17 finance ministers of the euro area) had to be shelved" (Pawlicki, 2012:86).

The opposition actors were presented in a completely different manner. The representation of Jarosław Kaczyński and his political party The Law and Justice (PiS) often assumed a deprecating and ironic tone. Jarosław Kaczyński was described as "steadfast" and ironically compared to Reytan"1, a deputy from late 18th century remembered for a dramatic gesture to prevent the legalization of the first partition of Poland (Paradowska, 2011b:34). Also the mechanisms of psychologization or even psychiatrization ("obsessed Kaczyński") were used (Łakomski, 2011:28). The traditionalism of Kaczyński was identified as anachronistic, and resulted in his description as an "antediluvian fossil" (Krzemiński, 2011b:12). The Law and Justice party was the subject of direct criticism (Materna, 2011:9) and polemics with slogans, past statements and beliefs promoted by the party (Krzemiński, 2011b:12). The demands of the opposition were ridiculed (Ibidem) and their significance belittled ("cat music") (Baczyński, 2011:12). Generally, the largest opposition party and its leader were alternately portrayed either as a threat to the Polish Presidency or as completely anachronistic and anti-European political actors unable to recognize reality.

Representation of the internal situation in Poland was not a particularly important part of the discourse on the Presidency, and such references were sporadic and usually implied. Three themes dominated: the domestic economic situation, diagnosis of social support for the EU, and the parliamentary elections which were to be held during the Presidency. At an economic level, Poland was portrayed as a country doing exceptionally well during the global downturn, a strong and valuable member of the EU. At the social level, emphasis was put on the Euro-enthusiasm of the society, underlined equally by journalists and their interlocutors, both Polish and the EU politicians ("overwhelming support for the European idea") (Dowgielewicz, 2011:90). Parliamentary elections, an important political parameter of the Presidential period, were regarded as a danger, especially because of the potential

1 Tadeusz Rejtan tried to prevent the legalization of the first partition of Poland in 1773. A 1866 painting by Jan Matejko pictures Rejtan lying on the threshold of a chamber trying to prevent the members of parliament from entering it and signing the partition document [translator's note]. 
negative exploitation of European issues by the political opposition. The argument by the opposition that the government could exploit the Presidency in their electoral propaganda was not discussed. This reversal of the argument concerning the elections was a clear sign of support for the government. In this perspective, the Presidency was represented as not only an advantage to the government, but a possible burden during elections (Paradowska, 2011a:15).

\section{Presidency - expectations and hopes}

In both weeklies the timeline heavily influenced writing about the Presidency. Descriptions of the event were divided into a preliminary and a final stage. The discourse first focused on the expectations and hopes associated with obtaining the position, and then on summaries and evaluations. The basic premise in both types of expression was belief in the great significance of the Presidency for Poland, while perceiving its limited powers at a European level and the short duration (Baczyński, 2011:12). For example, M. Dowgielewicz, a government plenipotentiary for the Polish Presidency, said in an interview: "It is important to have realistic expectations for the Presidency. It is only 184 days, so we can only initiate certain processes" (Dowgielewicz, 2011:90).

Researchers of the EU discourse have repeatedly pointed to the presence of the EU topos as a national test (Krzyżanowski, 2008:290; Zuk, 2010:106-107). This way of thinking was also present in a discourse on the Presidency. In particular, following issues were discussed: mobilization, hopes for the future, fear of failure, the problem of shame after failure. All of them clearly indicate that the conceptual field for the Presidency was closely associated with perceiving it as a task, an examination, a test meant to certify a new kind of identity. Accordingly, the Presidency was represented as a "national project of strategic importance for the Polish state", being "the largest logistical operation in the history of the Polish government to date." Its importance was emphasized by the identity-formation function of the Presidency. The presidency was supposed to actually change the identity of the state by making it a full member of the EU (Ostrowski \& Świeboda, 2011:52).

The part of the discourse on the Presidency which related to the future, made use of sentences with deontic modality, i.e. expressing a duty, obligation, but also the expectations of the speaker (Grzegorczykowa, 2001:133). Opinions using this type of modality, ("Poland must build coalitions carefully", "Poland should therefore mention it as often as possible"), were formulated by journalists and experts (Ostrowski \& Świeboda, 2011:52). On the other hand, the government plenipotentiary, M. Dowgielewicz formulated his assertions and declarations using expressions such as "we will begin", "we will dismantle" or "we will try" (Dowgielewicz, 2011:90).

The main expectations formulated by journalists and experts included, among other things, an active and dynamic Presidency, influencing the European agenda; 
constructing a narrative about the EU which would provide a pro-integration impetus for stagnating Europe; launching a debate on a new European solidarity, preventing division into a two speed Europe; and Poland's involvement in the European Neighbourhood Policy in the South (Ostrowski \& Świeboda, 2011:52). Similarly, the expressions of M. Dowgielewicz related to energy, the benevolence of Poland, and also the compatibility of Polish interests with those of the EU. In addition to mentioning the Polish priorities, the plenipotentiary (similar to the journalists and experts) drew attention to the rhetorical and symbolic importance of the Presidency: "First of all we will try to change the mood in the depressed crisis-stricken Union to a more optimistic one" (Dowgielewicz, 2011:90).

\section{Image of Europe/EU}

The vision of a successful Presidency, and the accompanying argumentation, were closely associated with the vision of a future Europe. However, the point of departure was a diagnosis of a current situation, including problems that the Presidency was supposed to address. All statements were based on normative assumptions about what the EU should be. The current image of the EU was similar to the inter-governmentalist concept where the EU institutions are considered to be the effects of the rational decisions of member states striving to solve problems (Wiener \& Diez, 2004:8). Therefore, texts mentioned a slow action of the EU institutions which must reconcile individual interests with the interests of the Union as a whole, or the different interests of individual countries which must be reconciled by the EU institutions. Such a vision of Europe was close to a liberal perspective in the theory of international relations, which perceives the multiplicity of interests as a kind of natural state of affairs resulting from the pluralism of agents (Lewandowski, 2011a:13).

Secondly, the community of interests was presented as a project or a perspective of international relations built within the EU institutions rather than a natural element of identity: "We must know and honestly talk about all differences and discrepancies. At the same we must build a better understanding of our common interests". (Ostrowski, 2012:46). Characteristically, this vision of Europe was legitimised instrumentally as an institutional system that is more functional for solving global problems than a nation state (Eriksen \& Fossum, 2004:437). J. Baczyński wrote, for example, that "it is increasingly clear that any of the significant problems that the governments of the EU members states face cannot be solved individually" (Baczyński, 2011:12).

Thirdly, the normative vision of Europe referred to a federal concept of the EU. The motto of the Polish Presidency "More Europe in Europe", which unambiguously showed the pro-integration orientation of the government, was frequently repeated in the statements of politicians (Lewandowski, 2011a:13; Dowgielewicz, 2011:90) and experts (Kucharczyk, 2012:92). The federational sympathies of Po- 
lityka and Wprost were also clearly visible in the titles of texts: "More Europe in Europe", "Together where only we can", "European Commonwealth". They encouraged implementation of a more federal-oriented policy through the use of a rhetorical tool of fabricating consequences, by presenting a pessimistic scenario (Kochan, 2005:99) - squandering the "great success of our accession to the EU" (Kucharczyk, 2012:92). A. Krzemiński (Polityka) agreed with R. Sikorski on the threat of pushing Poland eastwards. The alternative constructed by the journalist was: "Either Poland enters the core of the EU through co-creating efficient federal structures, or - as Ukraine - it will slip eastwards into political and economic grasslands" (Krzemiński, 2011b:12).

Fourthly, all authors emphasized the significant changes in the intergovernmental status quo, posing a serious threat to the functioning of the EU as a whole, and which started to appear after 2005. Among the factors responsible for disrupting the EU stability, the authors mentioned erosion of the legitimacy of the EU, the growing strength of re-nationalization tendencies, and the economic crisis. The EU was anthropomorphized. Namely, the texts referred to its "sloth", lack of "energy", "vigour", or "great idea", the pessimistic "mood" (Lewandowski, 2011a:13; Baczyński, 2011:12; Pawlicki, 2012:86; Dowgielewicz, 2011:90). The tendencies towards more nationalist attitudes were described negatively as egoistic (Krzemiński, 2011a). There was also a negative term of "extremely anti-European parties" (Lewandowski, 2011a:13). Populism was presented also by metaphors referring to natural disasters, for example compared to a tidal wave (Pawlicki, 2012).

Metaphorization was also used to describe the crisis as a fire (Ostrowski \& Świeboda, 2011:52), flood or fever (Ostrowski, 2012:46). The discursive construction of the crisis was not the instrument of hyperbolization, but rather it was used to legitimize the reformist ideas that were leaning towards federalism (Krzemiński, 2011a, b; Świeboda, 2011). In this approach, the crisis was not a dysfunction that showed an incorrect structure of the whole, but rather as a stage of development leading to a deeper integration (Lewandowski, 2011a:13).

Fifthly, the federalist vision forces questions about the relations between the EU and Poland, primarily the relation to the discrepancy between national and EU interests. In both weeklies, the membership of Poland in Europe and a non-antagonist nature of mutual relations were subjects to no doubt. The EU was supposed to be a natural environment for Poland as the nation state, and a object of natural loyalties of Poles. For Poland, that was supposed to mean the "end of history" in the sense of reaching the status quo, sufficiently and permanently ensuring Polish national interests (Ostrowski, 2012:46). One of the articles included the intertextual reference to the interview with Prime Minister Donald Tusk in Polityka in 2009, in which he mentioned a strict dependence between the economic growth and modernization of Poland and the progress of European integration. The author's praise of the PM presents the uniqueness of D. Tusk in comparison to other European politicians who had started to distance themselves from the EU (Baczyński, 2011:12). 


\section{Evaluation of the Presidency}

Both weeklies present a positive evaluation of the event, formulated by their journalists and interviewees from a political field. Critical opinions, when appeared, used language that emphasized positive intentions ("good intentions", "political will"), or failures limited to selected areas, with a generally positive opinion about the Presidency as a whole (Pawlicki, 2012:86). Also, at the level of evaluation, Polityka maintained the image of the Presidency as a task, writing that "during the Presidency, Warsaw did a good job" (Ostrowski, 2012:46). A similar metaphor was used by J. Pawlicki, who evaluated the Presidency as a "passed exam" (Pawlicki, 2012:86).

This success was not presented just as the effect of the efforts of the country as a whole. The reference to the words of D. Tusk in the context of the Polish Presidency personalized the effects and ascribed them to the Prime Minister. The journals not only included their own evaluations, but also created an opportunity for reviewing the Presidency by the politicians and officials preparing and overseeing the Presidency. For example, in an article summarizing the Polish Presidency, Wprost cited solely K. Niklewicz (spokesman for the Polish Presidency), who for example, commented on the question of the patent package: "It is a great success, given the negotiations on a uniform European patent have taken 30 years" (Ibidem).

Polityka and Wprost put a great emphasis on the opinions of the EU and its constituent entities, and hence often cited positive opinions of European politicians, for example on the Polish readiness to eschew partisanship (Ibidem). Positive evaluations were strengthened by underlining the unique situation during the Presidency, ("a difficult period", "the most difficult Presidency in the history of the EU") (Mielnik, 2012:90; Pawlicki, 2012:86), or the usually critical language of the EU politicians. The latter mechanism was used by Jakub Mielnik when he compared the words of Martin Schulz (President of the European Parliament) about Poland ("the best Presidency in years") and his reaction to the Czech President during Czech Presidency ("a few years ago he scolded President Klaus at Hradčany") (Mielnik, 2012:90). Apart from expressing opinions, the authors often listed individual achievements of the Polish Presidency, using verbs in the past perfect tense: "Poland had exerted an influence of the European politics, it had shown its significance as a political player, it had prepared the Accession Treaty for Croatia, it had saved the food aid programme" (Kucharczyk, 2012:92; Pawlicki, 2012:86).

\section{Presidency as appearance}

Ch. Perelman indicates that argumentation technique that is quite rarely mentioned in lectures on traditional rhetoric is the dissociation of concepts. In particular, he writes about the construction of division between the appearance and the reality, where the latter is a criterion that makes possible to distinguish between significant 
and insignificant. The dissociation of concepts enables the construction of hierarchy and the evaluation of possible aspects of the defined situation. For example, the use of the expression "apparent democracy" presupposes the notion of "real democracy", treated as a system of reference (Perelman, 2004:144). In the case of discourse on the Polish Presidency the division between appearance and reality was an important technique used by the weekly Uważam Rze, critical towards the government of Donald Tusk. The appearance was a category used first of all with regard to the Presidency, and so to the decisions and actions of D. Tusk in the international arena and in domestic politics. That double approach also served to describe the EU and its institutions. The division into appearance and reality was the principle used in the construction of argumentation strategies and metaphors in items on the Presidency published in Uważam Rze.

\section{Social and political actors - quotation and representation}

In Uważam Rze the issues associated with the Presidency or politics in the European scale were not given as much attention as the domestic politics. The texts that were entirely focused on the Presidency were editorials and opinion articles, written by authors not specializing in international politics, such as the editor-in-chief Pawef Lisicki, Dorota Gawryluk, and Michał Karnowski. The selection of interlocutors in interviews about the Presidency is also characteristic. The analysed corpus of texts includes four interviews, three of which were carried out with opposition politicians: Adam Bielan (a politician of PiS and later of its splintering party Polska Jest Najważniejsza), Ludwik Dorn (a right-wing opposition politician, cooperating with PiS and its splintering party Solidarna Polska), Anna Fotyga (a member of PiS and a former PiS Minister of Foreign Affairs and a close associate of the President Lech Kaczyński), with the fourth interview carried out with Arnulf Baring, presented as a German historian, political scientists, law specialist, and a best-selling author.

The examined corpus is characterized by a very low number of quotations, both direct and indirect. There are no statements by the PM, the Minister of Foreign Affairs, and the spokesman for the Polish Presidency K. Niklewicz. There is only one quotation of M. Dowgielewicz (Słojewska, 2011). Characteristically for a journal with right-wing sympathies, quotations (direct and indirect) on Europe often came from Pope John Paul II (Gawryluk, 2011a). But the discursive mechanism of exclusion of social actors, through the absence of governmental statements, exposing the voices of the opposition, was only one of the instruments used to construct the anti-government stance.

Another mechanism was based on a specific way of presenting social agents. Although references to the government were based on functionalization: "Prime Minister", "Minister of Foreign Affairs", "President of the European Parliament", "Minister of Finances", the labels, ways of describing actions, and ascribed character traits or contexts in which those politicians were mentioned, were negative. The 
authors wrote about Donald Tusk: "Donald Tusk let himself get trapped", and about the Minister of Finances, J. Rostowski: "He hid information about the most important problems in the EU, accepting some kind of a hybrid decision-making mechanism [...]. He accepted another extra-Treaty degradation of leadership" (Fotyga, 2011). The Minister of Foreign Affairs was described as a "main specialist in killing off flocks (of opposition, referring to his questionable remark during 2007 elections) or a "darling of the mainstream media" (Ozdowy, 2011:63). In the political dimension, the significance of D. Tusk and the politicians of his government were systematically degraded. Depreciation was performed through psychological attributions, ascribing them naivety, lack of dignity, vanity, dishonesty, excessive compliance (e.g. Dorn 2011:56; Fotyga, 2011).

Secondly, the importance of D. Tusk was belittled using ironic comparisons of labels in the foreign press: "President of Europe", "man responsible for the entire EU" and the actions of the largest Member States that did not pay attention to the Polish Presidency (Karnowski, 2011a:59). Many texts included statements that indicated tendencies of numbing the voices of the opposition, or even the authoritarian manner of ruling the country. This was also associated with the construction of historical analogies to communist Poland (Gawryluk, 2011a:57). In the context of the Polish Presidency, an especially significant accusation was the abandonment of the defense of Polish national interests for the sake of purely publicity-related actions (Fotyga, 2011).

Contrary to critical and ironic remarks about D. Tusk and the ministers, the image of PiS was decidedly positive. The construction of this image was based on several strategies. First of them was victimization. PiS was presented as a victim of the authoritarian tendencies of the D. Tusk's government and a subject to "destruction", "repressions", or even "extermination" (Czabański, 2011:52; Wildstein, 2011a:54). Secondly, PiS was presented affirmatively as a competent political party with more realistic approach to the European issues, in line with Polish interests, and with a "down-to-earth" programme for the Polish Presidency (Czabański, 2011). This pattern of argumentation was supported by references to the period when PiS was a governmental party (years 2005-2007). Durig that time, according to Fotyga (2011: 20) PiS attempted "to elevate the position of Poland, justified by the size and the potential of the country". Fourthly, J. Kaczyński was portrayed as a strong leader who "acted tough and defended the Polish national interest" (Bielan, 2011:26). His brother, President Lech Kaczyński was also presented as a statesman, capable of distinguishing between the national interest and propaganda (Fotyga, 2011).

\section{Presidency and the domestic situation}

Representation of the domestic situation was an important part of the analysed discourse. The definition of the status quo was based mainly on the hyperbolization of 
a threat on the side of the government and indication of the dramatic situation of the persecuted opposition (Zdort, 2011:59). The description of political conditions resembled an authoritarian state and the attempts of suspending the difference between non-democratic states and Poland were frequent. For example, L. Dorn said in an interview: "I am far from presenting Poland as Belarus, but this government is indeed testing how far it may go" (Dorn, 2011:56).

Elections were a significant element of internal situation's descriptions. While in Polityka and Wprost journalists expressed fears that the opposition may use the Presidency to criticize the government, the interlocutors and journalists of Uważam Rze were afraid of marginalizing domestic problems due to the focus on EU politics. Such approach to elections not only revealed a different hierarchy of events (domestic elections being more important that the Presidency) used by analysed media organizations, but also the journal' s political orientation. Uważam rze was actually afraid that a symbolic dimension of the Presidency may strengthen the government (Bielan, 2011; Dorn, 2011; Fotyga, 2011; Gawryluk, 2011a).

The deprecation of the Presidency in Uważam Rze was articulated in several ways. Fo rexample, the hierarchy of significance presented in other media was questioned through the expression "media hysteria" (Bielan, 2011:26). M. Karnowski pointed out a difference between the image of the Presidency and its real status, writing in passive voice that the "ordinary" and "trivial" event was "trumped up" to the rank of the "historic and exceptional" (Karnowski, 2011b:3). Moreover, the framework used during coverage of the events and actions associated with the Presidency led to an impression that it was a wasteful elitist spectacle (Burdzy, 2011:38). Belittling the significance of the Presidency was strongly associated with argumentation that the government was actually creating an image, building a fasade, or even using a propaganda. The government's was accused of paying attention exclusively on image creation:

"we would have much more to say if we were not focused solely on publicity (...). For some time, the general line of the Polish foreign policy has been a pure game of appearances focused on publicity. Our partners can sense it. They know that our government will give a lot in real business for a few praises, pats on the back, a sentence here and there about being European leaders, to then be sold nicely in the Polish media."

[Fotyga, 2011:20]

Justification of the deprecation of the Polish Presidency was based on legal arguments and the argument of a lack of the government's direct merit in this regard: "It was not our doing, it was in the schedule" (Bielan, 2011:26). Also, the mottos of the Polish Presidency were presented as unrealistic and reduced to "nice-sounding slogans", "empty words", or "words in vain" (Gawryluk, 2011b:59). By contrast, the programme of the opposition political party - PiS was described as "down to earth". Furthermore, the party's agenda was often covered by Uważam rze. For example, one of the opposition's priorities was to follow "the teachings of the Pope 
John Paul II on Europe" (Priorities of the Polish Presidency in the EU according to PiS 2011). Almost exact idea appeared in D. Gawryluk's article indicating that one of the deficiencies of the Polish Presidency was a lack of references to values expressed by the Polish Pope (Gawryluk, 2011a:57).

In Uważam Rze, like in Polityka and Wprost, a timeline played a significant role in the organization of discourse, although in Uważam rze hopes and expectations were replaced by concerns. They were based on the assumption on an inadequate hierarchy of priorities of the Presidency. A focus on publicity stunts, ascribed to the government, were contrasted with "real" and "serious" actions that would defend the Polish national interest, and emphasized the axiological dimension, crucial from the point of view of the situation in Europe (Fotyga, 2011:20; Gawryluk, 2011a:57). Concerns expressed by interlocutors and journalists referred to a few issues, such as: a possibility of using the symbolic value of the Presidency by D. Tusk, and an inability of the opposition to counteract it (Dorn, 2011); the probability of blocking the articulation of opposition parties or social discontent (Gawryluk, 2011a); the inability to pursue Polish interests due to the excessive dependence on good opinion from Western partners (Fotyga, 2011); or strengthening the symbolic dominance in the sphere of culture (Wildstein, 2011b).

\section{Image of Europe/EU}

The image of the EU in the analysed discourse was based on a system of assumptions typical for realism in the theory of international relations. First, the significance of a nation state is a basic entity in the international arena. This view is associated with a view on marginalization of the significance of the EU by the strongest member states, mainly Germany and France (Karnowski, 2011a). The strength and role of an international organization is decided by the interests of its major powers ("egoisms of the great") (Fotyga, 2011:20). Secondly, the depicted ontology of the international environment is strictly related to the antagonistic character of international relations, based on a zero sum game. This was the basis for the assertion that the position of the Polish Presidency was purely formal, hiding the real role of "strong states" (Ibidem). The European crisis shown the lack of will to compromise in pursuing the interests of major powers and revealed the real balance of power (Karnowski, 2011a). In this approach, striving to improve the international position of Poland is always bound to face opposition from other countries. Since the international system is perceived as an anarchic power game, a nation state is seen as the best means to ensure national interests. As M. Karnowski wrote: "It is still valid that if you want peace, prepare for a war" (Karnowski, 2011b:3).

Thirdly, the EU was not presented as a community, but rather an arena for pursuing national interests. The perception of the EU as a community was ascribed to the government and this vision was treated as dangerous naivety. In Uważam Rze, the EU was legitimised technocratically as a network of relations that protects against 
the arbitrary policies of stronger states. This is the reason behind fears of a 'two-speed Europe', not its federalist premises (Lisicki, 2011a:3). Fourthly, the normative concept of the future Europe on which the analysed discourse is based, is Europe of homelands, "the association of states responsible for their own fates", contrasted against a concept of a super-state which violates the principle of sovereignty. An interview with A. Baring contains expressions typical for eurosceptics: "eurocrats", "empty rhetoric about the United States of Europe", "superstate", "directives from Brussels" (Baring, 2012:52).

Fifthly, the definition of the current state of the EU focused on negative and crisis-related aspects. The journalists mentioned the "economic downturn threatening Europe", "real problems" of Europe, "chaos in the EU" (Karnowski, 2011b:3; Zaremba, 2011:14). The crisis was represented as a phenomenon that may lead to the breakdown of the entire EU and proof that the EU is economically unfounded, ideologically driven project. Sentences with weaker modality only suggested a probability of the EU disintegration, while sentences with strong modality treated the breakdown as an axiom: "It is not easy to predict that the EU has no chance to continue in its previous shape," "The common home of Europe and the common currency were phantasmagoria from the very beginning, and the present actions are doomed to failure" (Gawryluk, 2011b:59; Baring, 2012:52).

The breakdown of the EU was not a part of the rhetoric of fear, warning against the end of the EU, but a part of nationalist discourse, calling for a focus on internal interests. In other words, journalist were not afraid of the EU collapse; they used the image of crisis to justify the nationalist ideas. Moreover, the problems of the EU were explained by using a dualist division into appearance and reality. According to this view, the existing institutions were only appearances, due to their inadequacy for the requirements of the reality. In this case, appearance reflected the ideological character of the institutional system (Lisicki, 2011a).

Different discursive strategies served to represent the EU as the other. For example, the deixis "there" built the opposition between the EU and Poland as the deictic centre "here": "Because a good impression is the only thing that counts there" (Gawryluk, 2011b:59). Texts openly used, or presupposed, comparisons to the communist or Nazi regimes (Gawryluk, 2011b; Baring, 2012). Othering was also performed by the positioning of the EU elites on a right-left scale at the position opposite to the journal's line. The authors wrote about the left-wing roots of the EU and the desire to uproot national traditions from modern societies. The pejorative explanation of the term 'Europe' ("Europe, the canon of negation") was accompanied by a series of statements that defined the situation as a "culture war" (Wildstein, 2011b:54).

Finally, in contrast to the discourse about the EU as a task, where the EU was treated as the natural environment for Poland and the accessionto the EU was presented as the end of history, in the discourse of the Presidency as appearance the EU was juxtaposed with Poland and the interests and identities in these two areas were presented as alternatives. Europeanisation was presented as a zero sum game 
threatening the Polish identity (Ibidem), and the interest of the Prime Minister in European matters was a kind of liability that weakens the efficiency of domestic policies (Gawryluk, 2011b).

\section{Evaluation of the Presidency}

In the analysed discourse, negative evaluations of the Polish Presidency had occurred during its six months. According to the authors of Uważam rze, the Presidency had not fulfilled the task of strengthening the Polish voice in Europe: "The Polish Presidency in the EU shows that the voice from Warsaw has little effect there" (Ozdowy, 2011:63). The symbolic or rhetoric dimension of the Presidency that seemed to be important for the government and the authors in Polityka and Wprost, in Uważam rze is showed as a proof of the superficiality of the EU institutions and is treated as a material for building negative opinions. However, the evaluations presented in Uważam Rze were rarely explicit and usually assumed the form of meta-commentaries, referring critically or affirmatively to the others' evaluations. For example, the editor-in-chief of Uważam Rze wrote: "Right were those who shown that the Presidency is primarily a symbol and we should not pay too much attention to it" (Lisicki, 2011a:3).

Authors who critisized the Presidency used irony concerned not only a subject matter per se, but also those who expressed positive opinions: "Poland, I have no doubt, is a model country. For long six months it carried on its shoulders the burden of crisis, bravely and successfully leading the European Union. It is not surprising, therefore, that when finally the Prime Minister Donald Tusk arrived at the headquarters of the European Parliament with the feeling of a job well done, he was greeted with only appreciation, thanks and loudly expressed admiration" (Lisicki, 2012b:3). The hyperbolization used in this fragment stands in sharp contrast to the critique of the Presidency and the government, known from other texts published in the journal.

\section{Conclusions}

The aim of this paper was to analyze the image of the Polish Presidency in three Polish weeklies treated as political actors that intervene in the space of the actions of politicians responsible for the Presidency and those remaining in opposition. Due to the specific frames of perception, two discursive positions were developed: Presidency as a task, and Presidency as an appearance. The radically different constructs of reality that were realized through these discourses were visible in a representation of individual political and social actors, the Polish Presidency, and the definition of situation in Poland, as well as the image of the EU and the evaluation of the Presidency. 
The discourse presenting the Presidency as a task used in the articles and interviews of Polityka and Wprost assumed a consistently pro-government stance. It was expressed by an affirmative mechanisms of quotation and representations of the government side, a positive evaluation of its actions during the Presidency and the entire Presidency itself. Both titles supported a resolutely pro-integration attitude of the government, encouraging it to pursue further and deeper integration.

On the other hand, Uważam Rze, since being critical towards the government of Donald Tusk, ignored statements of the officials. The lack of quotations and a negative representation of the government officials contrasted with a positive image of the opposition. The evaluation of the domestic situation and the Presidency was also unambiguously critical. In the assumed realist perspective, the EU was presented as an appearance intended to conceal the real interests of the strongest member states. The Presidency was also presented as a mere appearance, devoid of significance, hollowed of real power and serving only to boost the image of the government.

Both positions express the current polarization of the Polish public sphere, where the expression of one's own identity is much more prevalent than the search for inter-subjectivity. In this sense, these postitions give an insight into the mechanisms of building a political conflict in Poland that ensnares a much greater area than solely the sphere of the European politics.

\section{References}

Baczyński, J. (2011), “Czy porwiemy Europę?” [Will we abduct Europe?], Polityka, July 6.

Baring, A. (2011), “Nagi król: rozmowa P. Cywińskiego" [Naked king: interview by P. Cywiński]. Uważam Rze, January 2, 52-54.

Bielan, A. (2011), “Wyborcze emocje: rozmowa J. Karnowskiego i M. Karnowskiego” [Electoral emotions: interview by J. Karnowski and M. Karnowski], Uważam Rze, August 8, 26-29.

Burdzy, P. (2011), “Celebryci zamiast potwora z Loch Ness” [Celebrities instead of the Loch Ness monster], Uważam Rze, June 27, 38-39.

Carvalho, A. (2008), “Media(ted) discourse and society. Rethinking the framework of Critical Discourse Analysis", Journalism Studies 9(2), 161-177.

Czabański, K. (2011), “Testowanie granic władzy” [Testing the limits of power], Uważam Rze, July 11, 52-54.

Diez, T., Wiener, A. (2004), "Introducing the mosaic of integration theory", in: A. Wiener, T. Diez (ed.), European Integration Theory, Oxford: Oxford University Press, 1-21.

Diez, T. (2001), “Europe as a discursive battleground. Discourse analysis and European integration studies", Cooperation and Conflict 36(1), 5-38.

Dorn, L. (2011), “Jak punktować Tuska?: rozmowa P. Zaremby" [How to score Tusk: interview by P. Zaremba], Uważam Rze, June 27, 56-58.

Dowgielewicz, M. (2011), “Trzymajcie kciuki: rozmowa J. Pawlickiego” [Keep your fingers crossed: interview by J. Pawlicki], Wprost, July 18, 90. 
Ericksen E. O., Fossum J. E. (2004), “Europe in search of legitimacy: Strategies of legitimation assessed", International Political Science Review 25(4), 435-459.

Fotyga, A. (2011), "Cena pochwał i pozorów. Rozmowa M. Karnowskiego" [The price of praises and appearances], Uważam Rze, July 18, 20-23.

Gawryluk, D. (2011a), “Motor wartości” [The engine of values], Uważam Rze, July 4, 57.

Gawryluk, D. (2011b), "Ile jest Unii w Unii czyli słowa rzucane na wiatr" [How much Union is in the Union or speaking idly], Uważam Rze, December 29, 59.

Grzegorczykowa, R. (2001), Wprowadzenie do semantyki jezykoznawczej [Introduction to linguistic semantics], Warszawa: PWN.

Karnowski, M. (2011a), “Co dalej ... Z przewodzeniem Europie” [What's next... with the conduction of Europe], Uważam Rze, August 22, 56.

Karnowski, M. (2011b), "Rostowski nie zwariował" [Rostowski is not crazy], Uważam Rze, September 19, 3.

Kochan, M. (2005), Pojedynek na stowa. Techniki erystyczne w publicznych sporach [Verbal duel. Techniques in public disputes], Kraków: Wydawnictwo Znak.

Krzemiński, A. (2011a), "Niemieckie zwątpienie" [German doubt], Polityka, September 14, 42-44.

Krzemiński, A. (2011b), “Rzeczpospolita Europa” [Republic Europe], Polityka, December 7, 12-14.

Krzyżanowski, M. (2008), “Konstrukcja tożsamości narodowych i europejskich w polskim dyskursie politycznym po 1989 roku: analiza dyskursywno-historyczna" [National and European identity construction in Polish political discourse after 1989: A discursive and historical analysis], in: A. Duszak, N. Fairclough (eds), Krytyczna analiza dyskursu. Interdyscyplinarne podejście do komunikacji społecznej [Critical analysis of a discourse. Interdisciplinary approach to social communication], Kraków: Universitas, 267-303.

Kucharczyk, J. (2012), “Więcej Europy w Europie: rozmowa P. Pisery” [More Europe in Europe: interview by P. Pisera], Wprost, January 2, 92.

Lewandowski, J. (2011a), “Może kryzys nam pomoże: rozmowa J. Żakowskiego” [Maybe crisis will help us: Interview by J. Żakowski], Polityka, July 6, 13-15.

Lewandowski, J. (2011b), “Pod ostrzałem: rozmowa J. Pawlickiego” [Under fire: interview by J. Pawlicki], Wprost, July 18, 92.

Lipiński, A. (2010), “Europe as a symbolic resource. On the discursive space of political struggles in Poland", KFG Working Paper Series 10, available at: http://www.polsoz.fu-berlin.de/en/v/transformeurope/publications/working_paper/wp/wp10/ index.html, [accessed on 24.06.2013].

Lisicki, P. (2011a), “Europa dwóch prędkości to wyzwanie" [Two-speed Europe is a challenge], Uważam Rze, August 22, 3.

Lisicki, P. (2011b), “W krzywym zwierciadle” [In a distorted mirror], Uważam Rze, December 27,3 .

Łakomski, G. (2011), “Rok pod żyrandolem” [A year under the chandelier], Wprost, June 4, 28-30.

Materna, K. (2011), “Wdzięk, masowość, bezpretensjonalność” [Grace, mass, and unpretentiousness], Wprost, July 11, 9.

Mielnik, J. (2012), “Do czterech razy sztuka” [Fourth time lucky], Wprost, 2 January, 90.

Młynarski, T. (2011), “Wyznaczniki efektywności prezydencji w Radzie Unii Europejskiej w świetle reformy Traktatu Lizbońskiego" [Indicators of the EU Council presidency's 
effectiveness according to the Lisbon Treaty reform], in: A. Nowak-Far (ed.), Prezydencja w Unii Europejskiej. Praktyka i teoria [The EU presidency. Practice and theory], Warszawa: Szkoła Główna Handlowa - Oficyna Wydawnicza.

Nowak-Far, A. (2011), “Wstęp" [Introduction], in: A. Nowak-Far (ed.), Prezydencja w Unii Europejskiej. Polska 2011 [The EU presidency. Poland 2011], Warszawa: Szkoła Główna Handlowa - Oficyna Wydawnicza.

Ostrowski, M. (2012), "Razem, gdzie tylko się da" [Together, wherever we can], Polityka, January 11, 46-47.

Ostrowski, M., Świeboda P. (2011), “My, prezydenci” [We, presidents], Polityka, June 15, 52-54.

Ozdowy, T. (2011), "Co dalej... Z Radosławem Sikorskim” [What's next... with Radosław Sikorski], Uważam Rze, October 10, 63.

Page, B. I. (1996), “The mass media as political actors”, PS: Political Science and Politics 29(1), 20-24.

Paradowska, J. (2011a), “Karty w tas” [Shifting cards], Polityka, July 13, 15.

Paradowska, J. (2011b), “Rok w zawieszeniu” [A year in suspension], Polityka, December 21, 34-35.

Pawlicki, J. (2012), “Prezydencja. Zdany egzamin” [Presidency. Passed exam], Wprost, January 2,36 .

Perelman, Ch. (2004), Imperium retoryki. Retoryka i argumentacja [Empire of rhetoric. Rhetoric and argumentation], Warszawa: PWN.

Priorytety polskiej prezydencji w UE według PiS 2011 (2011), available at: http:/ / www.pis.org.pl/article.php?id=18840 [accessed on 23.05.2013].

Reisigl, M. (2008), “Analyzing political rhetoric”, in: R. Wodak, M. Krzyżanowski (eds), Qualitative discourse analysis in social sciences, Houndmills-New York: Palgrave, 96-120.

Reisigl, M., Wodak, R. (2001), Discourse and discrimination. Rhetorics of racism and anti-Semitism, London-New York: Routledge.

Słojewska, A. (2011), "Fakty i mity. Polska prezydencja” [Facts and myths. Polish presidency], Uważam Rze, July 4, 10.

Środa M. (2011), "Średniowiecze w unijnych barwach" [The Middle Ages in EU color], Wprost, July 4, 31.

Świeboda, P. (2011), “Unia wymyśla się na nowo" [Union is reinventing itself], Wprost, September 5, 3-4.

Van Leeuwen, T. (2008), Discourse and practice. New tools for critical discourse analysis, Oxford: Oxford University Press.

Wildstein, B. (2011a), “Opozycja do psychiatryka” [Opposition should go to a psychiatrist], Uważam Rze, September 27, 52-54.

Wildstein, B. (2011b), “Kulturowa tyrania mniejszości” [The cultural tyrrany of the minority], Uważam Rze, August 8, 54-56.

Wojtak, M. (2004), Gatunki prasowe [Press genres], Lublin: Wydawnictwo UMCS.

Zaremba, P. (2011), “Tusk ma z kim przegrać” [Tusk has a partner to lose to], Uważam Rze, October 3, 14-17.

Zdort, M. (2011), “Co dalej... Z kampanią wyborczą" [What's next... with the electoral campaign], Uważam Rze, August 16, 59.

Żuk, G. (2010), Twierdza czy wspólnota? Europa w polskim dyskursie publicznym [Fortress or community? Europe in Polish public discourse], Lublin: Wydawnictwo UMCS. 



\section{Contributors}

Madalina Balasescu is an assistant professor at the University of Bucharest at the Faculty of Journalism and Communication Sciences.

Daniël Biltereyst is a senior full professor and chair of the Department of Communication Sciences, Ghent University, Belgium. He is the director of the Centre for Cinema and Media Studies (CIMS).

Thibault Bonte holds a master degree in Communication Sciences after graduating at Ghent University (Belgium) in 2012.

Eveline Delcart holds a master degree in Communication Sciences after graduating at Ghent University (Belgium) in 2012.

Julie De Smedt is a researcher and project coordinator at the Television News Archive, a Flemish government sponsored institute monitoring television news media in Flanders, Belgium. She is a member of the research group $\mathrm{M}^{2} \mathrm{P}$ (www.m2p.be) at the department of Political Science of the University of Antwerp, Belgium.

Knut De Swert is an assistant professor in Political Communication and Journalism at the Department of Communication Science at the University of Amsterdam, the Netherlands and is a member of the Amsterdam School of Communication Research (ASCoR).

Andreas Hepp is a professor in Media and Communication Studies at the ZeMKI, University of Bremen.

Stijn Joye is an assistant professor at the Department of Communication Sciences, Ghent University, Belgium.

Artur Lipiński is an assistant professor at the Faculty of Political Science and Journalism at the Adam Mickiewicz University in Poznań, Poland.

Valentina Marinescu is an associate professor at the University of Bucharest at the Faculty of Sociology and Social Work.

Anne Mollen is a research assistant in the project "The Transnationalization of Public Spheres in Europe" within the collaborative research centre "The Transformations of the State", ZeMKI, University of Bremen.

Beata Ociepka is a professor of international relations and international communication at the University of Wrocław, Poland. She is a head of International Communication Section at the Institute of International Relations. 
Anke Offerhaus is a lecturer and postdoc researcher in the project "The Transnationalization of Public Spheres in Europe" within the collaborative research centre "The Transformations of the State", ZeMKI, University of Bremen.

Veronika Pitrová is a Czech journalist, currently working for the foreign news desk at the Czech Television. She holds a degree of Erasmus Mundus Master: Journalism, Media and Globalization from Universiteit van Amsterdam \& Aarhus University.

Sandrine Roginsky is an associate professor at the Catholic University Louvain (UCL), Belgium.

Javier Ruiz Soler holds a Master Degree in European Studies from the Lund University with a specialization in European communications. He has been collaborating in research on Global Television Discourse at the Stockholm University.

Bartłomiej Secler is an assistant professor at the Faculty of Political Science and Journalism at the Adam Mickiewicz University in Poznań, Poland.

Katerina Serafeim holds a PhD in journalism and mass media of the Aristotele University of Thessaloniki. She is a journalist at the Press Office of the Regional Local Government of Central Macedonia, Greece.

Agnieszka Stępińska is an assistant professor at the Faculty of Political Science and Journalism at the Adam Mickiewicz University in Poznań, Poland.

Gabriella Szabo is a full-time researcher at Center for Social Sciences, Hungarian Academy of Science.

Khaël Velders is a junior research and teaching assistant at the Department of Communication Sciences, Ghent University, Belgium.

Arjen van Dalen is an associate professor at the Center for Journalism at the University of Southern Denmark.

Romy Wöhlert is a junior scientist and lecturer at the Institute for Comparative Media and Communication Studies, Austrian Academy of Sciences \& Alpen-Adria-University Klagenfurt, Vienna, Austria. 

This timely book explores how the media shape the Europeanization of the public sphere within the European Union (EU). Bringing together a range of international scholars in media studies and journalism and covering both traditional and online media, it argues that Europeanization is not just an idea - it is a real, ongoing process that we are experiencing every day.

Assessing a wide range of actors and processes and acknowledging the diverse relationships between media and politics, the chapters edited by Agnieszka Stępińska reflect contemporary conceptualizations of Europeanization and unravel the complex mediatization of European politics. It covers topics as diverse as children's socialization within the European Union via kid's TV programmes; the impact of the 'Euroblogosphere' on policy decisions; and international broadcasting as one of the key elements to understanding new public diplomacy in Europe.

Using the Polish EU presidency of 2011 as an extensive case study, the book's latter part shows what impact Poland's presidency had on its representation, both domestically and abroad, and questions the Presidency's actual power of attracting media attention. 'Media and Communication in Europe' is a valuable resource for any student and researcher interested in the complex relationship between the media and the EU. 